\title{
Investigating Mexican Paleoclimate with Precisely Dated Speleothems
}

by

Gabriela Serrato Marks

B.A., Bowdoin College (2015)

Submitted to the Department of Earth, Atmospheric, and Planetary Sciences in partial fulfillment of the requirements for the degree of

Doctor of Philosophy

at the

MASSACHUSETTS INSTITUTE OF TECHNOLOGY

and the

WOODS HOLE OCEANOGRAPHIC INSTITUTION

September 2020

(C) Gabriela Serrato Marks. All rights reserved.

The author hereby grants to MIT and WHOI permission to reproduce and to distribute publicly paper and electronic copies of this thesis document in whole or in part in any medium now known or hereafter created.

Signature of Author

Joint Program in Oceanography/Applied Ocean Science and Engineering Massachusetts Institute of Technology \& Woods Hole Oceanographic Institution

August 20, 2020

Certified by

David McGee

Thesis Supervisor

Massachusetts Institute of Technology

Accepted by

Oliver Jagoutz

Chair, Joint Committee for Marine Geology \& Geophysics Massachusetts Institute of Technology 


\title{
Investigating Mexican Paleoclimate with Precisely Dated Speleothems
}

By

\author{
Gabriela Serrato Marks \\ Submitted to the MIT-WHOI Joint Program in Oceanography/Applied Ocean Science and \\ Engineering on August 20th, 2020, in Partial Fulfilment of the Requirements for the Degree of \\ Doctor of Philosophy
}

\begin{abstract}
:
Speleothems, or sedimentary rocks formed in caves, act as valuable archives of past climate change due to their suitability for U-series dating and high-resolution proxy analysis. These records can provide insights into water availability and controls on hydrology prior to the instrumental record. In this thesis, I present three records from newly-analyzed Mexican stalagmites using stable isotope (oxygen and carbon) and trace element to calcium $(\mathrm{Mg} / \mathrm{Ca}$ and $\mathrm{Sr} / \mathrm{Ca}$ ) ratios as proxies for changing hydroclimate. Chapter 2 presents a precisely dated, midHolocene record of high rainfall and limited precipitation variability in the Yucatan Peninsula, Mexico. Chapters 3 and 4 present novel climate records from northeastern Mexico, an understudied region of North America. Both records come from cave sites within the Mexican arid zone, which is simultaneously experiencing increased water scarcity and a rapidly growing population. In Chapter 3, I examine a speleothem from the first millennium of the Common Era, which showed that there is a precipitation dipole between northern and southern Mexico. Chapter 4 highlights, for the first time at decadal resolution, the northeast Mexican response to the $8.2 \mathrm{ka}$ event and the Younger Dryas. These chapters show that the San Luis Potosí region is vulnerable to droughts under multiple climate mean states, and is subject to drying as Atlantic Meridional Overturning Circulation weakens due to anthropogenic climate change. The climate records detailed in this thesis improve our understanding of controls on Mexican hydroclimate and can serve as benchmarks for climate models.
\end{abstract}

Thesis Supervisor: David McGee

Title: Associate Professor 


\section{Acknowledgements}

First, I want to note that there is no way to appropriately thank and acknowledge everyone who helped bring me to this point. I could write an entire thesis just about how much I appreciate my community of supporters. Completing this thesis would not have been possible without the help of countless mentors, advisors, and friends.

I would like to thank my advisor, David McGee, for his support and guidance throughout my time at MIT. Thank you for providing me with a lot of flexibility in my research and time, which allowed me to pursue many interests, form new collaborations, and create a scientific network. I feel extremely privileged to have gotten to focus on Mexico throughout my $\mathrm{PhD}$. I am also very grateful for the support from my other thesis committee members: Kristin Bergmann, Tripti Bhattacharya, Kathleen Johnson, and Caroline Ummenhofer. Individually, they are each excellent scientists and role models, and collectively, my committee was an incredible resource as I completed this thesis. I am also deeply grateful for the staff and faculty who make the MIT-WHOI Joint Program possible. I am very proud to be a JP alum. In addition, I want to thank the Bowdoin EOS department, especially Michèle LaVigne, my undergraduate thesis advisor. Thank you for giving me such an excellent foundation in geoscience and research.

My labmates and peers at MIT and WHOI were such an important part of the projects I write about in this thesis, from both scientific and social standpoints. Thank you to the McGee Lab Group, including Christine Chen, Michaela Fendrock, Adam Jost, Christopher Kinsley, Ben Tiger, Elena Steponaitis, Ben Hardt, and Irit Tal, for teaching me and supporting me through every step of grad school. Our lab, and this research, wouldn't be complete without the undergraduate researchers who have contributed so much to the group. I would especially like to thank Gabby Cazares and Sarah Weidman, MIT undergraduates who played key roles in this thesis. I also want to thank Kevin Wright, my counterpart at UC Irvine. He contributed to my research and education at every level, from analyzing all of the stable isotope powders in Chapters 3 and 4 to brainstorming future research questions (and preventing me from ending up with 15 chapters). Thank you for being the best field partner and co-graduate-investigator.

I am so appreciative of my family, near and far, who have helped me get to this point. Thank you to my fiancé, Alex Poon, for your patience, encouragement, and support. I couldn't have done this without you. To my grandparents, Beatrice Guzman and Emilio Serrato, my parents, Veronica Serrato and Richard Marks, my sibling, Jaime Serrato Marks, I can't thank you enough for making this possible. My family is the reason I speak Spanish, which came in handy throughout this research process. More importantly, they made sure I had a sense of pride in my Mexican-American heritage and that I always pursued every possible educational opportunity.

This work was funded by US National Science Foundation (NSF) grants AGS-1702848 (M. MedinaElizalde), AGS-1502877 (S. Burns), AGS-1804512 and AGS-1806090 (K. Johnson and D. McGee). I was also supported by the NSF Graduate Research Fellowship and the MIT School of Science Dean's Fellowship. Fieldwork and analysis were funded by the WHOI Ocean Ventures Fund, the MIT EAPS Student Research Fund, and the MIT International Science and Technology Initiatives (MISTI) Mexico program. Initial work for this project was also supported by UC MEXUS-CONACYT Collaborative Grant from the University of California Institute for Mexico and the United States (UC MEXUS CN-16120). Any opinions, findings, and conclusions or recommendations expressed in this material are those of the author and do not necessarily reflect the views of the National Science Foundation. 


\section{Table of Contents}

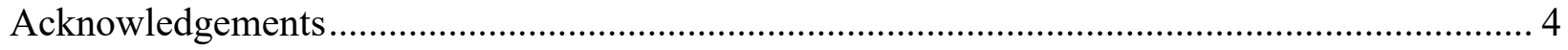

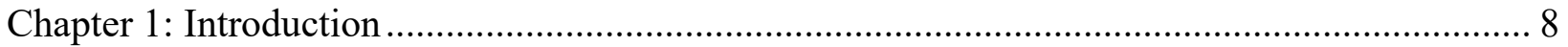

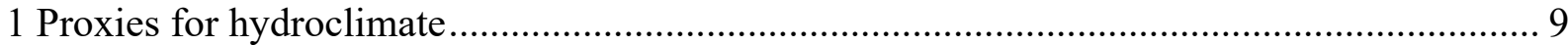

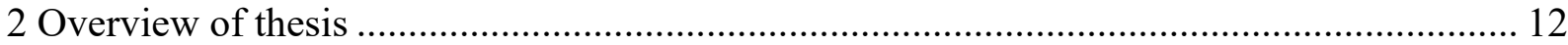

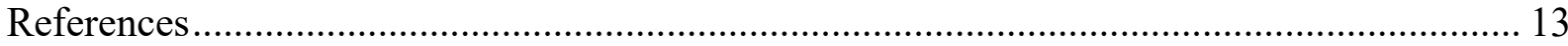

Chapter 2: Evidence for decreased precipitation variability in the Yucatán Peninsula during the

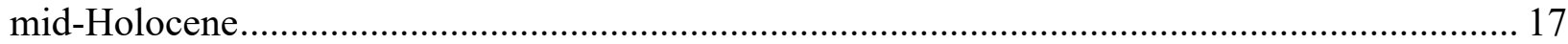

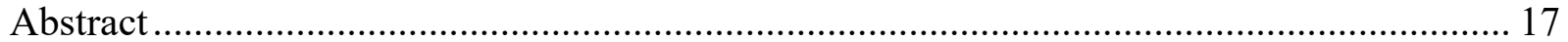

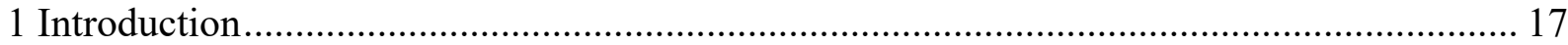

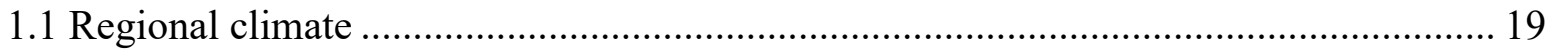

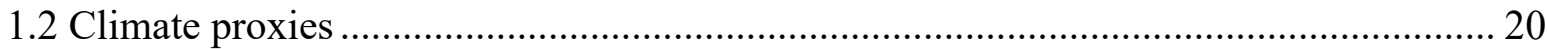

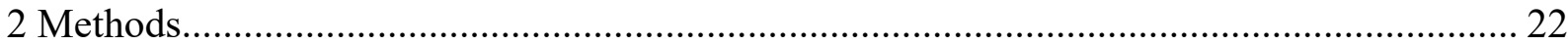

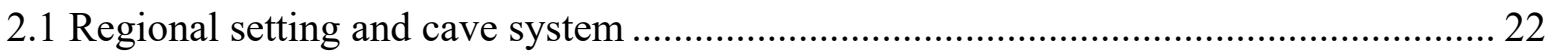

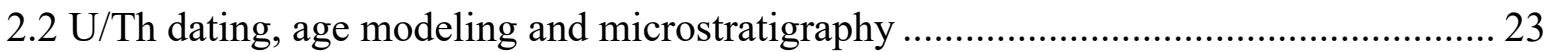

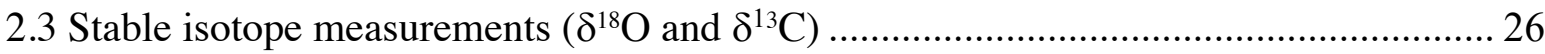

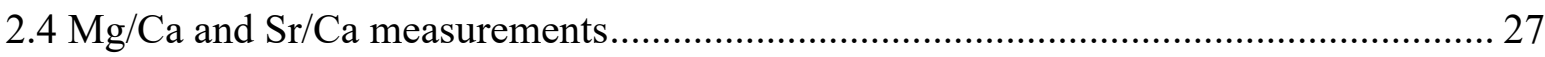

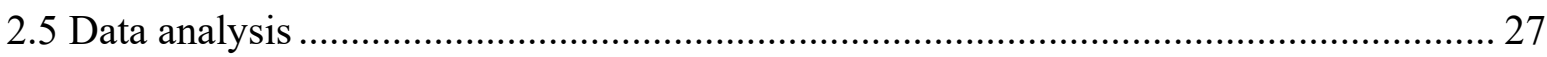

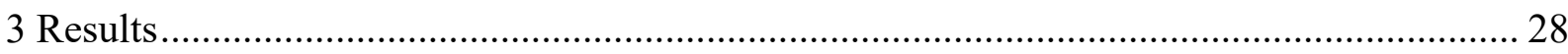

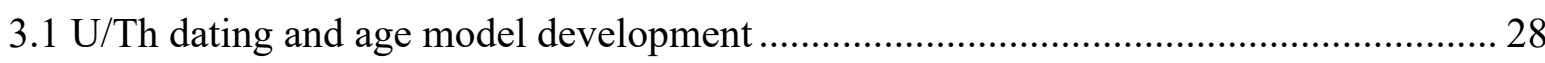

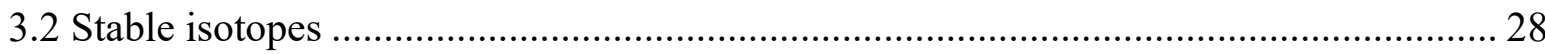

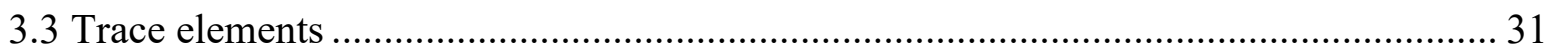

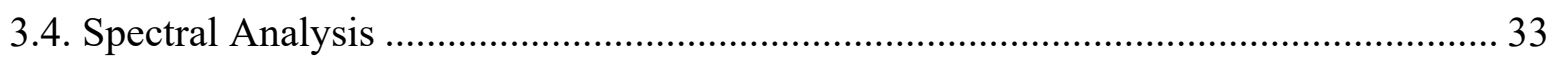

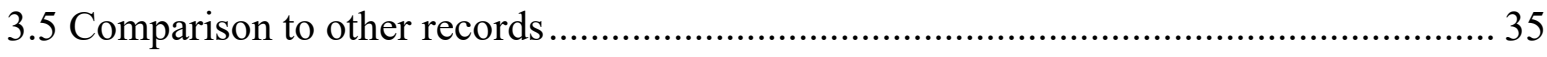

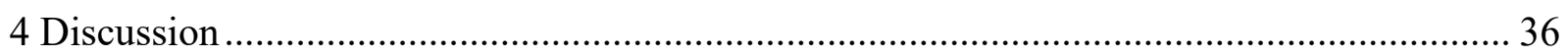

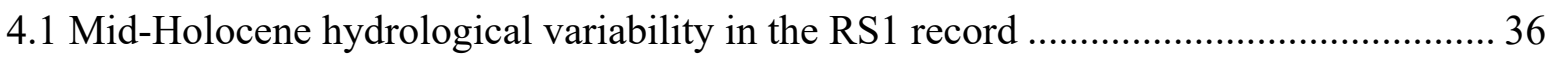

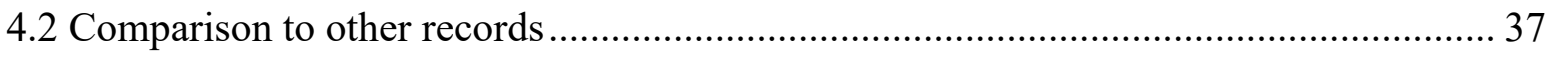

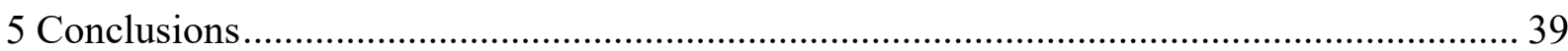

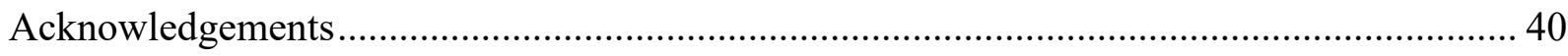

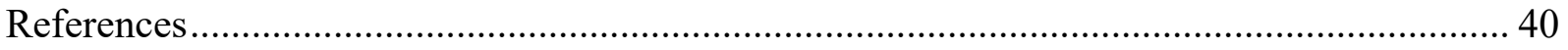

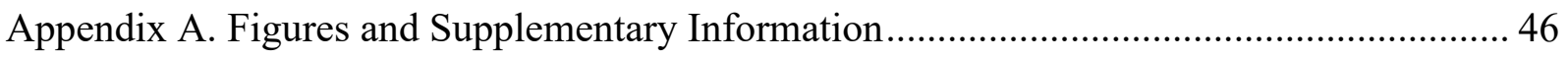

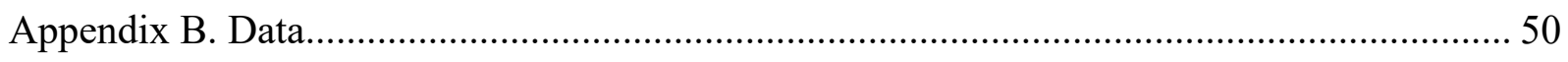

Chapter 3: New insights into northern Mexican paleoclimate during the first millennium of the

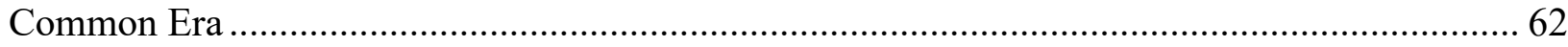

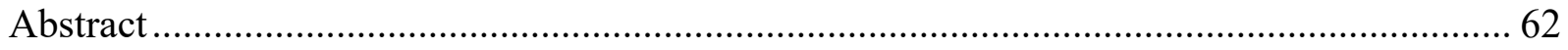




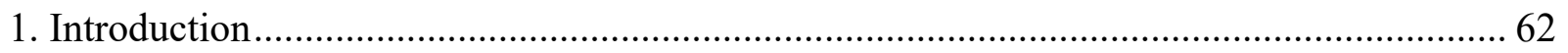

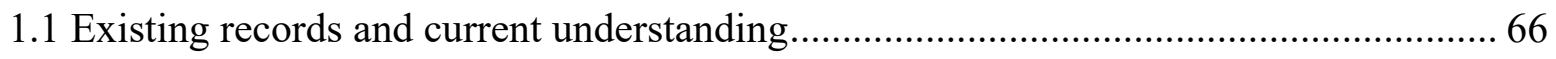

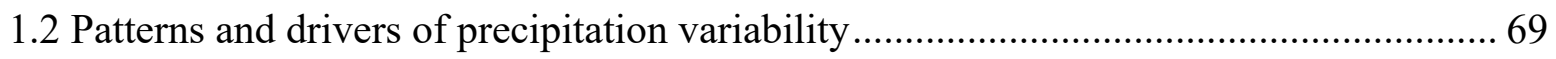

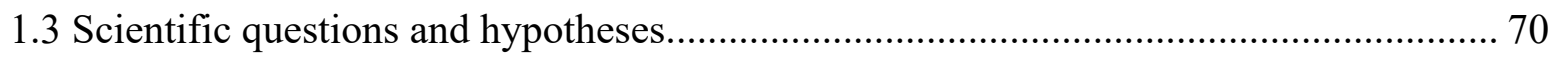

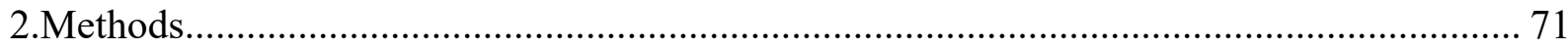

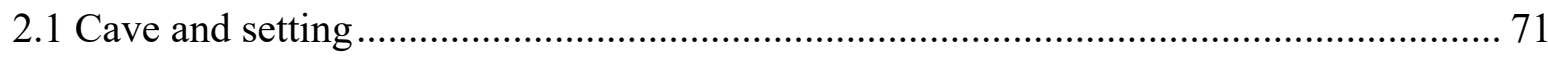

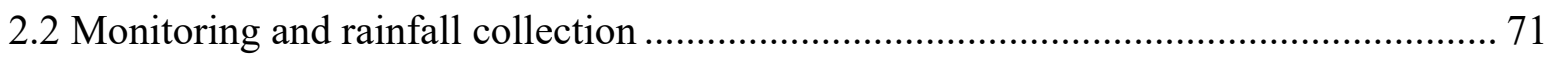

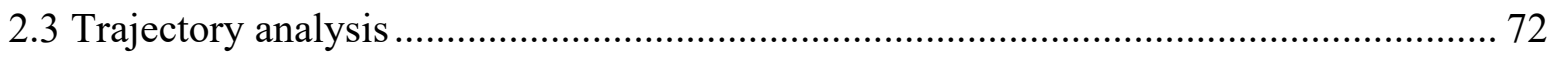

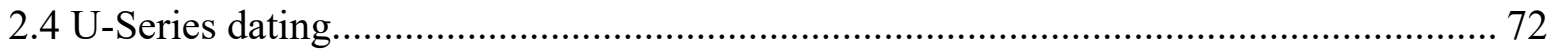

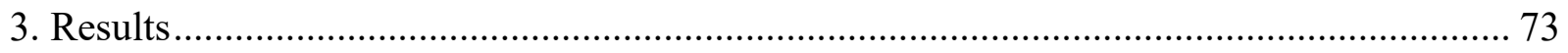

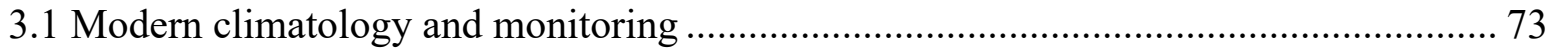

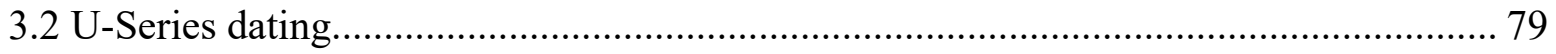

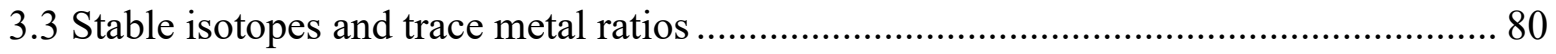

3.4 Mexican Early Classic Period (300-550 CE) ............................................................... 84

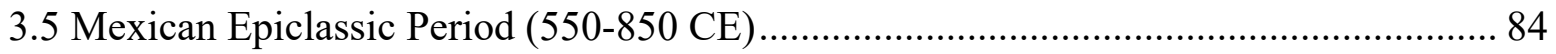

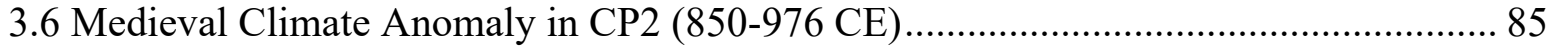

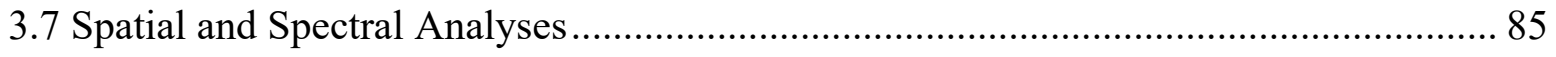

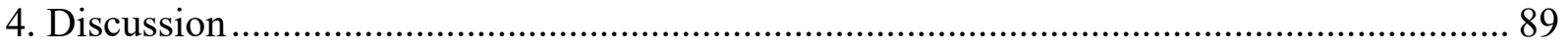

4.1 Mexican Early Classic Period (300-550 CE) ………....................................................... 89

4.2 Mexican Epiclassic Period (550-800 CE) ……………............................................ 90

4.3 Medieval Climate Anomaly in CP2 (850-976 CE) ................................................... 91

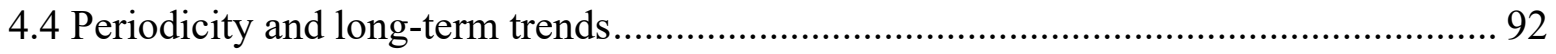

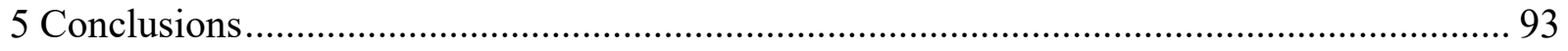

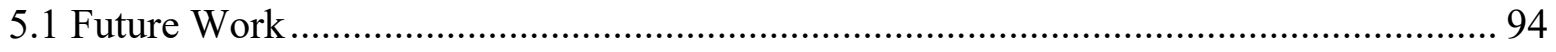

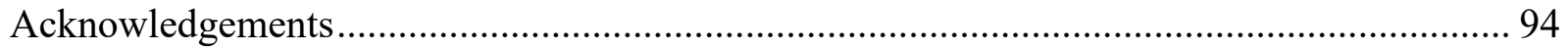

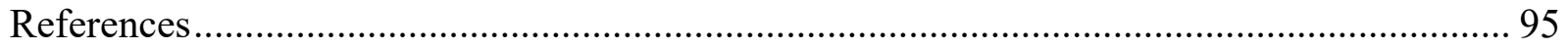

Appendix A: Figures and Supplementary Information...................................................... 101

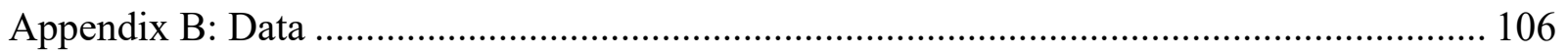

Chapter 4: A novel speleothem-derived record of drying during the $8.2 \mathrm{ka}$ event in northern

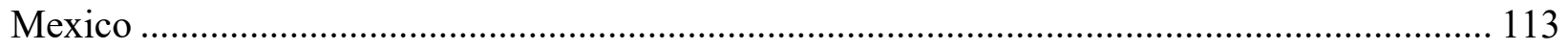

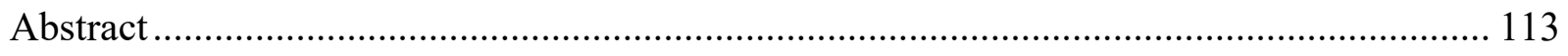

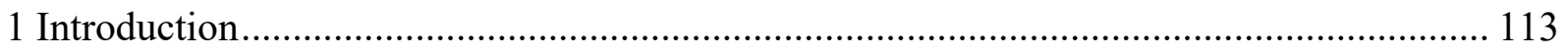

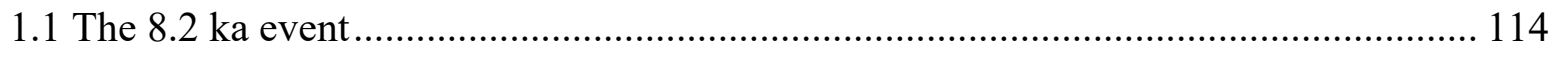

1.2 The Atlantic Meridional Overturning Circulation and Mexican Precipitation............. 118

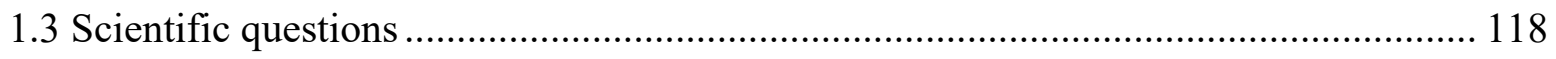




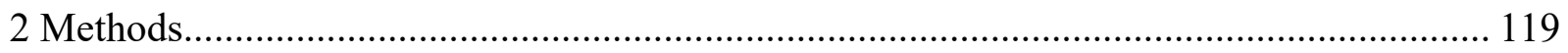

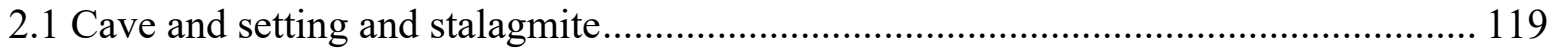

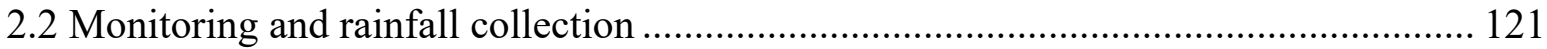

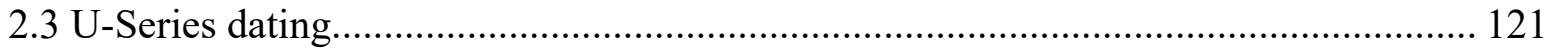

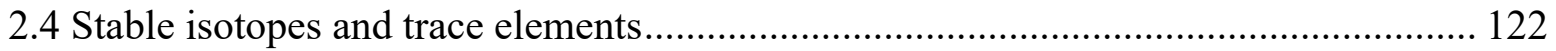

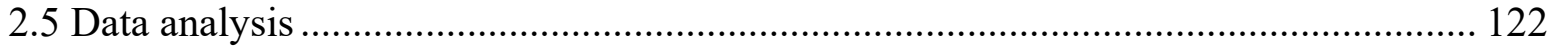

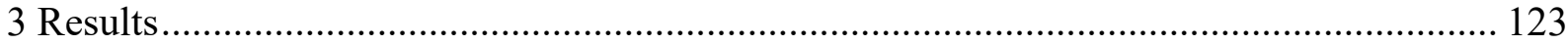

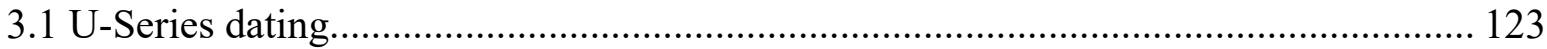

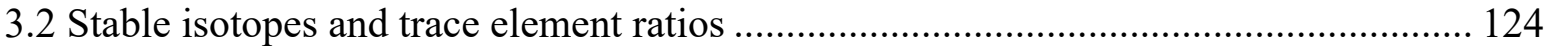

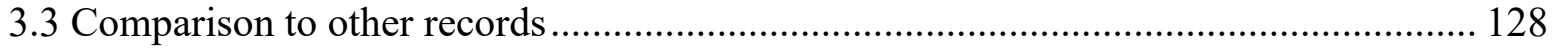

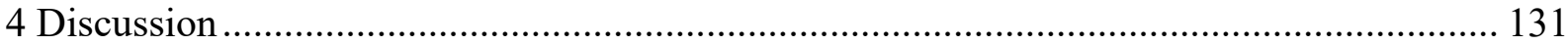

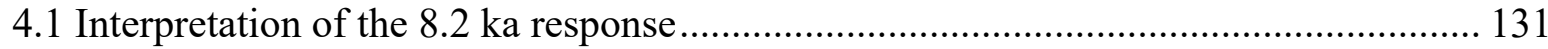

4.2 Implications for future climate change ………….................................................. 132

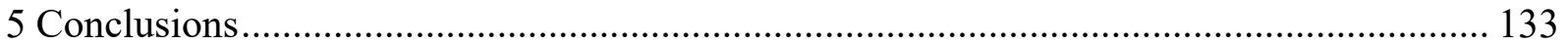

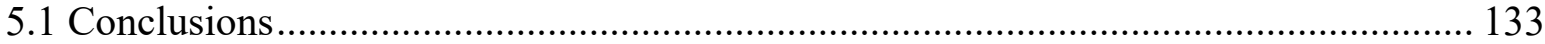

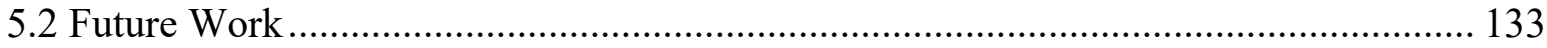

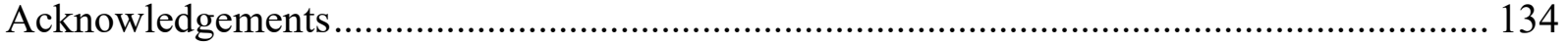

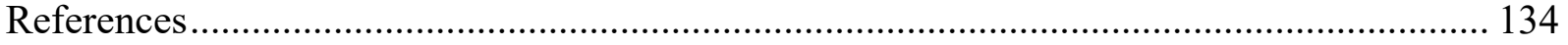

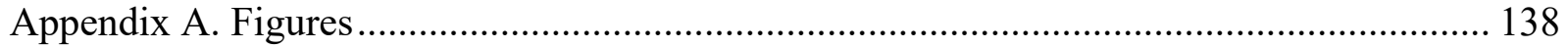

Appendix B. Data...................................................................................................... 140

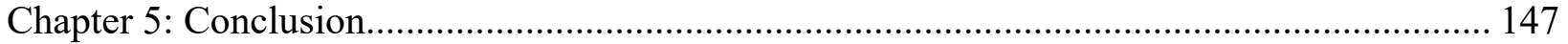

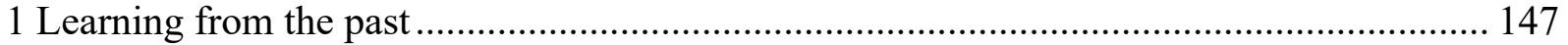

2 Preparing for future droughts................................................................................... 148

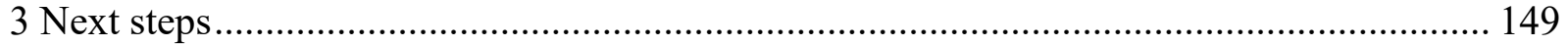

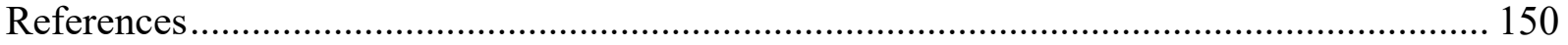




\section{Chapter 1: Introduction}

The paleoclimate record holds valuable insights about how regions around the world respond to different types of climate events or forces. While the past is never a perfect analog for the present or future, the history of Earth's climate may provide early warning about how anthropogenic climate change will change precipitation, temperature, and ocean-atmosphere feedbacks, among many other facets of the climate system. Most people are familiar with ice cores and tree rings, but those are just two of many kinds of paleoclimate archives. Each archive has its own strengths and weaknesses, making it necessary to use a variety of archives to adequately reconstruct past climates.

Speleothems, or sedimentary rocks formed in caves, act as another type of archive of past climate change. These records can provide insights into water availability and controls on hydrology prior to the instrumental record. Speleothems act like fossilized groundwater or precipitation, in that they capture the chemical signature of water that drips on them, which came from above the cave.

A few notes on vocabulary, before we continue: speleothems are any sedimentary rock from a cave, but stalagmites are specific formations that precipitate from liquid dropping from the ceiling onto the cave floor (Figures 1 and 2). All the rock records detailed in this thesis are stalagmites, but I will use both terms interchangeably. I will also use rainfall and precipitation interchangeably, as the vast majority of precipitation at the sites of interest falls in the form of rain.

Speleothems are particularly useful for reconstructions of paleoclimate due to their suitability for high-precision uranium-thorium (U/Th) dating and high-resolution proxy sampling. Unlike trees, they can grow for millennia; unlike sediment cores, their dating uncertainties can be in the sub-decadal range; unlike ice cores, they are found outside of the polar regions and high elevations. Throughout my time at MIT, I primarily focused on pursuing those small age uncertainties with U/Th dating. I have dated samples that grew 500,000 years ago and others from just a few decades ago. Each one seems to come with its own quirks and challenges, but when the stalagmite characteristics, chemical processing, and instrumental analysis align, the dates form the backbone of a speleothem research study. 
That said, without the stable isotope and trace elemental data that are plotted on the agedepth models I generate, the speleothems would be significantly less useful. For chapter 2, the stable isotope data came from Syee Weldeab's lab at UC Santa Barbara, in collaboration with modern data from Fernanda Lases-Hernandez at UNAM (Mexico) and other researchers at UMass Amherst and Auburn University. The stable isotope data in chapters 3 and 4 were generated by Kevin Wright and the UC Irvine Center for Isotope Tracers in Earth Sciences (CITIES). More broadly, chapters 3 and 4 represent just part of a collaboration between researchers at MIT, Syracuse, UC Irvine, and UNAM. More information on all collaborators can be found in the acknowledgements section of each chapter.

\section{Proxies for hydroclimate}

We rely on the chemical composition of stalagmites, $\mathrm{CaCO}_{3}$, to capture changes in hydroclimate. These chapters use stable isotope ratios of oxygen and carbon, commonly expressed as $\delta^{18} \mathrm{O}$ and $\delta^{13} \mathrm{C}$, and ratios of $\mathrm{Mg}$ and $\mathrm{Sr}$ to $\mathrm{Ca}$. There are other proxies, such as $\mathrm{Sr}$ isotopes, $\mathrm{Ca}$ isotopes, $\delta^{234} \mathrm{U}, \mathrm{U}$ concentration, and $\mathrm{U} / \mathrm{Ca}$, that are also useful in analyses of carbonates, but those will not be used here (Baldini et al., 2016; Pacheco-Forés et al., 2020).

In Mexico, $\delta^{18} \mathrm{O}$ records in stalagmites are generally interpreted to reflect changes in precipitation amount, with more negative $\delta^{18} \mathrm{O}$ values indicating increased precipitation, called the amount effect (Akers et al., 2016; Bernal et al., 2011; Lachniet et al., 2012; Lases-Hernandez et al., 2019; Medina-Elizalde et al., 2017; Medina-Elizalde \& Rohling, 2012). The amount effect describes the empirical relationship between precipitation amount and $\delta^{18} \mathrm{O}_{\text {precip }}$ composition observed in the tropics from seasonal to interannual timescales. Long-term monitoring has demonstrated that $\delta^{18} \mathrm{O}$ is negatively correlated with precipitation amount on a monthly scale, so more precipitation leads to lower $\delta^{18} \mathrm{O}$ (Lases-Hernandez et al., 2019).

Changes in $\delta^{13} \mathrm{C}$ can reflect a number of local processes, many of which are indirectly associated with moisture amount, in the soil and epikarst (Dreybrodt \& Scholz, 2011; Genty et al., 2006). Some of the most common controls include the ratio of $\mathrm{C} 3$ to $\mathrm{C} 4$ vegetation above the cave (Borsato et al., 2016; Burns et al., 2016; Fairchild et al., 2006; Tremaine et al., 2011) and the amount of degassing in the vadose zone (Fairchild et al., 2006; Lachniet et al., 2004; Steponaitis et al., 2015). At some cave sites where the overlying vegetation is expected to remain relatively stable over time, stalagmite $\delta^{13} \mathrm{C}$ variability can reflect precipitation amount, as 
observed in Belize (Asmerom et al., 2020; Kennett et al., 2012; Ridley et al., 2015). Rainfall amount can influence drip water $\delta^{13} \mathrm{C}$ (and therefore stalagmite $\delta^{13} \mathrm{C}$ ) by affecting soil moisture and organic matter production, bedrock dissolution, degassing, and prior calcite precipitation (PCP) (Borsato et al., 2016; Fairchild et al., 2000; Genty et al., 2006; Ridley et al., 2015; Wong $\&$ Breecker, 2015). Low precipitation enhances degassing and PCP, increases bedrock carbon contributions and decreases soil bio-productivity, all ultimately increasing drip water $\delta^{13} \mathrm{C}$ and stalagmite $\delta^{13} \mathrm{C}$ (Asmerom et al., 2020; Pollock et al., 2016; Ridley et al., 2015).

Although stalagmite $\delta^{18} \mathrm{O}$ and $\delta^{13} \mathrm{C}$ records have been widely interpreted as hydroclimate proxies, they are not without complexities or weaknesses. Stalagmite $\delta^{18} \mathrm{O}$ can also be influenced by changes in the $\delta^{18} \mathrm{O}$ of the moisture source, changes between different moisture sources, and upstream water vapor history (Konecky et al., 2019; Oster et al., 2019; Vuille et al., 2003; Wong et al., 2015). Similarly, stalagmite $\delta^{13} \mathrm{C}$ can be impacted by soil and karst processes not directly related to precipitation variability. Moreover, both $\delta^{18} \mathrm{O}$ and $\delta^{13} \mathrm{C}$ can also be affected by kinetic fractionation, especially in cave environments with lower relative humidity. Nonetheless, dozens of studies in the Americas present multiple lines of evidence that stalagmite $\delta^{18} \mathrm{O}$ and $\delta^{13} \mathrm{C}$ can record local and regional precipitation amount (Asmerom et al., 2020; Baldini et al., 2016; Medina-Elizalde et al., 2010, 2016; Medina-Elizalde \& Rohling, 2012; Pollock et al., 2016). Though they are useful, it is important to have additional proxies to confirm that the stable isotope data are primarily recording changes in hydroclimate.

Therefore, we also use other paleoclimate proxies, such as $\mathrm{Mg} / \mathrm{Ca}$ and $\mathrm{Sr} / \mathrm{Ca}$ ratios, to further constrain our understanding of precipitation change (or moisture amount) in stalagmite records. These chapters are the first studies that examine $\mathrm{Mg} / \mathrm{Ca}$ and $\mathrm{Sr} / \mathrm{Ca}$ ratios in speleothems from northern Mexico, with the exception of Wright et al. (in prep.), which is a collaboration with this project.

Previous research has established clear relationships between $\mathrm{Mg} / \mathrm{Ca}, \mathrm{Sr} / \mathrm{Ca}$, and precipitation change in other locations. Trace element to calcium ratios can track PCP and/or water-rock interactions, which change based upon soil and water conditions in the local environment (Fairchild et al., 2000; Sinclair, 2011; Sinclair et al., 2012; Steponaitis et al., 2015; Tremaine \& Froelich, 2013). In drier conditions, water moves more slowly through the karst above a cave, so it has more time to degas and become saturated with calcite (Tremaine \& Froelich, 2013). During PCP, Mg and Sr are preferentially excluded from the calcite crystal 
lattice, so $\mathrm{Mg} / \mathrm{Ca}$ and $\mathrm{Sr} / \mathrm{Ca}$ ratios in dripwater increase with PCP (Fairchild et al., 2000). Therefore, $\mathrm{Mg} / \mathrm{Ca}$ and $\mathrm{Sr} / \mathrm{Ca}$ in stalagmites provide an estimate of aquifer recharge and water availability that can serve as an independent proxy, and provide a method to examine whether stalagmite $\delta^{18} \mathrm{O}$ and $\delta^{13} \mathrm{C}$ primarily reflect changes in local moisture availability (Tremaine \& Froelich, 2013).

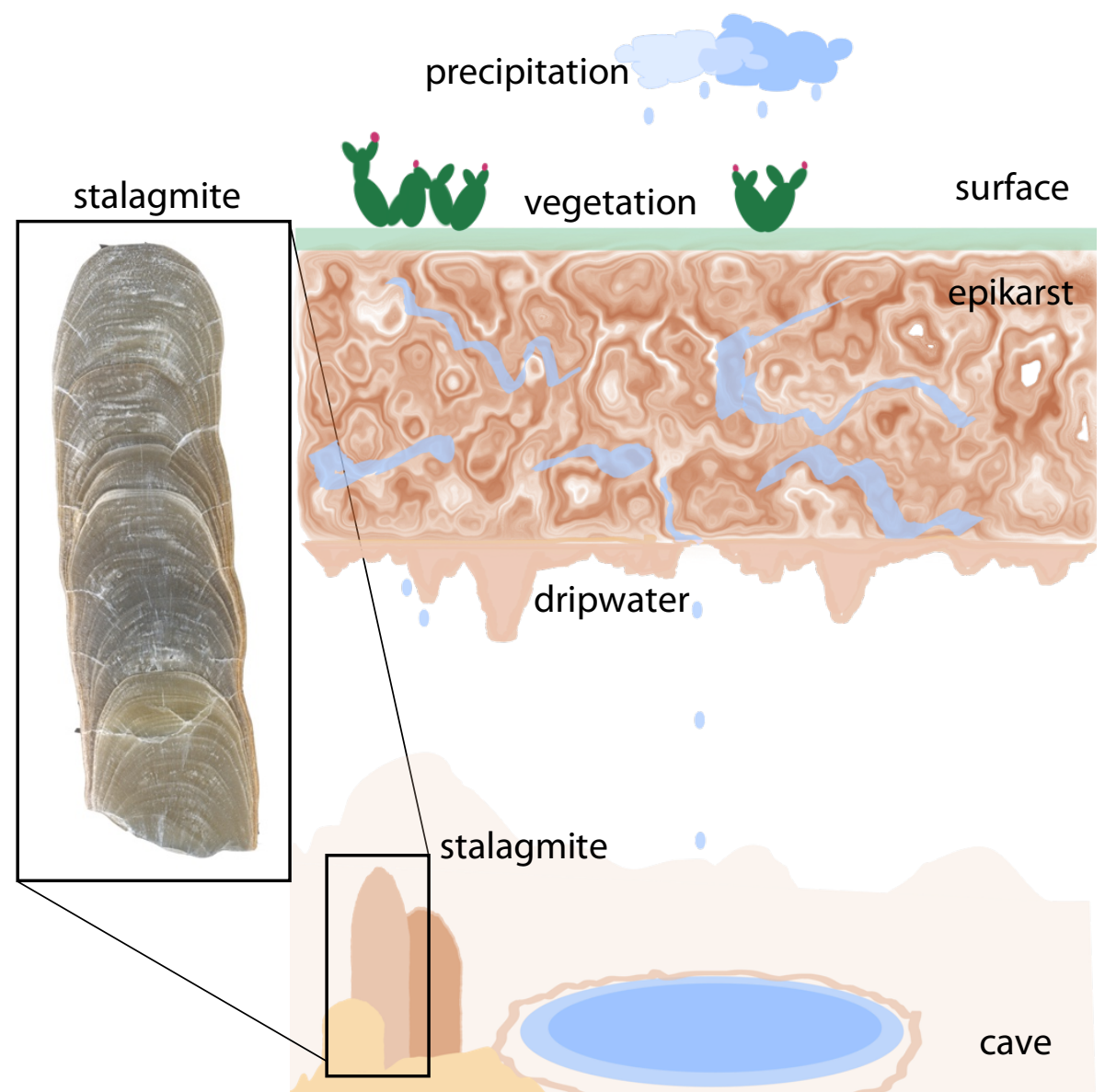

Figure 1. Schematic cross section of a cave and relevant surface features, like cacti. Inset shows a sectioned stalagmite. 


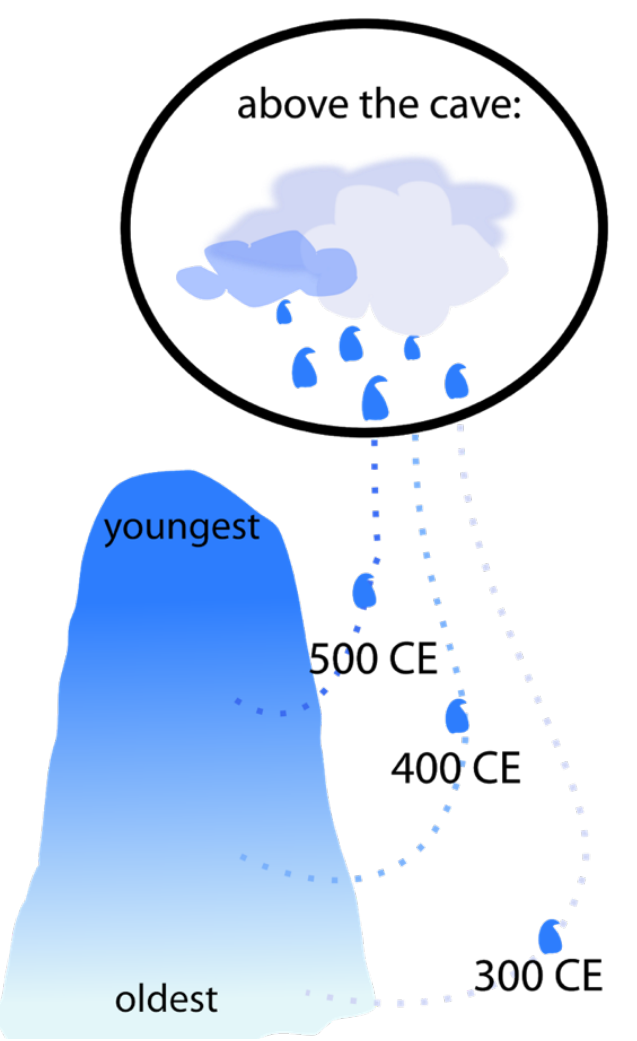

Figure 2. Schematic showing how stalagmites capture precipitation signatures over time as they grow upward.

\section{Overview of thesis}

In this thesis, I present three records from newly-analyzed Mexican stalagmites using stable isotope (oxygen and carbon) and trace element to calcium $(\mathrm{Mg} / \mathrm{Ca}$ and $\mathrm{Sr} / \mathrm{Ca}$ ) ratios as proxies for changing hydroclimate.

Chapter 2 presents a precisely dated, mid-Holocene record of high rainfall and limited precipitation variability in the Yucatán Peninsula (YP), Mexico. The YP has been studied extensively during the Common Era ( $0 \mathrm{CE}$ to present) because of interest in the relationship between Maya civilization and climate change (Douglas et al., 2015; Frappier et al., 2014; Hodell et al., 2005; Hunter et al., 2019; Medina-Elizalde et al., 2010, 2016; Neff et al., 2006; Stahle et al., 2011). However, the region lacks data on older periods in YP history, including the mid-Holocene. I demonstrate that the YP was wetter and less variable around 5,000 years before present (BP), in comparison to the late Holocene. 
Chapters 3 and 4 present novel climate records from northeastern Mexico, an understudied region of North America. Both records come from cave sites within the Mexican arid zone, which is simultaneously experiencing increased water scarcity and a rapidly growing population. In Chapter 3, I examine a speleothem from the first millennium of the Common Era, which showed that there is a precipitation dipole between northern and southern Mexico. Chapter 4 highlights, for the first time at decadal resolution, the northeast Mexican response to the $8.2 \mathrm{ka}$ event and the Younger Dryas, which are widely studied in European records. These chapters show that the San Luis Potosí region is vulnerable to droughts under multiple climate mean states, and is subject to drying as Atlantic Meridional Overturning Circulation weakens due to anthropogenic climate change. The climate records detailed in this thesis improve our understanding of controls on Mexican hydroclimate and can serve as benchmarks for climate models.

\section{References}

Akers, P. D., Brook, G. A., Railsback, L. B., Liang, F., Iannone, G., Webster, J. W., Reeder, P. P., Cheng, H., \& Edwards, R. L. (2016). An extended and higher-resolution record of climate and land use from stalagmite MC01 from Macal Chasm, Belize, revealing connections between major dry events, overall climate variability, and Maya sociopolitical changes. Palaeogeography, Palaeoclimatology, Palaeoecology, 459, 268-288. https://doi.org/10.1016/j.palaeo.2016.07.007

Asmerom, Y., Baldini, J. U. L., Prufer, K. M., Polyak, V. J., Ridley, H. E., Aquino, V. V., Baldini, L. M., Breitenbach, S. F. M., Macpherson, C. G., \& Kennett, D. J. (2020). Intertropical convergence zone variability in the Neotropics during the Common Era. Science Advances, 6(7), eaax3644. https://doi.org/10.1126/sciadv.aax3644

Baldini, L. M., Baldini, J. U. L., McElwaine, J. N., Frappier, A. B., Asmerom, Y., Liu, K. B., Prufer, K. M., Ridley, H. E., Polyak, V., Kennett, D. J., MacPherson, C. G., Aquino, V. V., Awe, J., \& Breitenbach, S. F. M. (2016). Persistent northward North Atlantic tropical cyclone track migration over the past five centuries. Scientific Reports, 6 . https://doi.org/10.1038/srep37522

Bernal, J. P., Lachniet, M., McCulloch, M., \& Mortimer, G. (2011). A speleothem record of Holocene climate variability from southwestern Mexico. Quaternary ....

Borsato, A., Johnston, V. E., Frisia, S., Miorandi, R., \& Corradini, F. (2016). Temperature and altitudinal influence on karst dripwater chemistry: Implications for regional-scale palaeoclimate reconstructions from speleothems. Geochimica et Cosmochimica Acta. https://doi.org/10.1016/j.gca.2015.11.043

Burns, S. J., Godfrey, L. R., Faina, P., McGee, D., Hardt, B., Ranivoharimanana, L., \& Randrianasy, J. (2016). Rapid human-induced landscape transformation in Madagascar at the end of the first millennium of the Common Era. Quaternary Science Reviews, 134, 9299. https://doi.org/10.1016/j.quascirev.2016.01.007 
Douglas, P. M. J., Pagani, M., Canuto, M. A., Brenner, M., Hodell, D. A., Eglinton, T. I., \& Curtis, J. H. (2015). Drought, agricultural adaptation, and sociopolitical collapse in the Maya Lowlands. Proceedings of the National Academy of Sciences of the United States of America, 112(18), 5607-5612. https://doi.org/10.1073/pnas.1419133112

Dreybrodt, W., \& Scholz, D. (2011). Climatic dependence of stable carbon and oxygen isotope signals recorded in speleothems: From soil water to speleothem calcite. Geochimica et Cosmochimica Acta. https://doi.org/10.1016/j.gca.2010.11.002

Fairchild, I. J., Borsato, A., Tooth, A. F., Frisia, S., Hawkesworth, C. J., Huang, Y., McDermott, F., \& Spiro, B. (2000). Controls on trace element ( $\mathrm{Sr}-\mathrm{Mg})$ compositions of carbonate cave waters: implications for speleothem climatic records. Chem Geol, 166(3-4), 255-269. https://doi.org/10.1016/s0009-2541(99)00216-8

Fairchild, I. J., Smith, C. L., Baker, A., Fuller, L., Spötl, C., Mattey, D., \& McDermott, F. (2006). Modification and preservation of environmental signals in speleothems. EarthScience Reviews. https://doi.org/10.1016/j.earscirev.2005.08.003

Frappier, A. B., Pyburn, J., Pinkey-Drobnis, A. D., Wang, X., Corbett, D. R., \& Dahlin, B. H. (2014). Two millennia of tropical cyclone-induced mud layers in a northern Yucatán stalagmite: Multiple overlapping climatic hazards during the Maya Terminal Classic "megadroughts." Geophysical Research Letters, 41(14), 5148-5157. https://doi.org/10.1002/2014GL059882

Genty, D., Blamart, D., Ghaleb, B., Plagnes, V., Causse, C., Bakalowicz, M., Zouari, K., Chkir, N., Hellstrom, J., Wainer, K., \& Bourges, F. (2006). Timing and dynamics of the last deglaciation from European and North African $813 \mathrm{C}$ stalagmite profiles-comparison with Chinese and South Hemisphere stalagmites. Quaternary Science Reviews. https://doi.org/10.1016/j.quascirev.2006.01.030

Hodell, D. A., Brenner, M., \& Curtis, J. H. (2005). Terminal Classic drought in the northern Maya lowlands inferred from multiple sediment cores in Lake Chichancanab (Mexico). Quaternary Science Reviews, 24(12-13), 1413-1427. https://doi.org/10.1016/j.quascirev.2004.10.013

Hunter, S., Allen, D., \& Kohfeld, K. (2019). Spatial and temporal variability of Terminal Classic Period droughts from multiple proxy records on the Yucatan Peninsula, Mexico. Climate of the Past Discussions. https://doi.org/10.5194/cp-2019-68

Jamieson, R. A., Baldini, J. U. L., Brett, M. J., Taylor, J., Ridley, H. E., Ottley, C. J., Prufer, K. M., Wassenburg, J. A., Scholz, D., \& Breitenbach, S. F. M. (2016). Intra- and inter-annual uranium concentration variability in a Belizean stalagmite controlled by prior aragonite precipitation: A new tool for reconstructing hydro-climate using aragonitic speleothems. Geochimica et Cosmochimica Acta, 190, 332-346. https://doi.org/10.1016/j.gca.2016.06.037

Kennett, D. J., Breitenbach, S. F. M., Aquino, V. V., Asmerom, Y., Awe, J., Baldini, J. U. L., Bartlein, P., Culleton, B. J., Ebert, C., Jazwa, C., Macri, M. J., Marwan, N., Polyak, V., Prufer, K. M., Ridley, H. E., Sodemann, H., Winterhalder, B., \& Haug, G. H. (2012). Development and Disintegration of Maya Political Systems in Response to Climate Change. Science, 338(6108), 788-791. https://doi.org/10.1126/science.1226299

Konecky, B. L., Noone, D. C., \& Cobb, K. M. (2019). The Influence of Competing Hydroclimate Processes on Stable Isotope Ratios in Tropical Rainfall. Geophysical Research Letters. https://doi.org/10.1029/2018GL080188

Lachniet, M S, Burns, S. J., \& Piperno, D. R. (2004). A 1500-year El Niño/Southern Oscillation 
and rainfall history for the isthmus of Panama from speleothem calcite. Journal of .... https://doi.org/10.1029/2004JD004694

Lachniet, Matthew S., Bernal, J. P., Asmerom, Y., Polyak, V., \& Piperno, D. (2012). A 2400 yr Mesoamerican rainfall reconstruction links climate and cultural change. Geology, 40(3), 259-262. https://doi.org/10.1130/G32471.1

Lases-Hernandez, F., Medina-Elizalde, M., Burns, S., \& DeCesare, M. (2019). Long-term monitoring of drip water and groundwater stable isotopic variability in the Yucatán Peninsula: Implications for recharge and speleothem rainfall reconstruction. Geochimica et Cosmochimica Acta, 246, 41-59. https://doi.org/10.1016/j.gca.2018.11.028

Medina-Elizalde, M., Burns, S. J., Lea, D. W., Asmerom, Y., von Gunten, L., Polyak, V., Vuille, M., \& Karmalkar, A. (2010). High resolution stalagmite climate record from the Yucatán Peninsula spanning the Maya terminal classic period. Earth and Planetary Science Letters, 298(1-2), 255-262. https://doi.org/10.1016/j.epsl.2010.08.016

Medina-Elizalde, M., Burns, S. J., Polanco-Martinez, J., Lases-Hernández, F., Bradley, R., Wang, H. C., \& Shen, C. C. (2017). Synchronous precipitation reduction in the American Tropics associated with Heinrich. Scientific Reports, 7(1). https://doi.org/10.1038/s41598$017-11742-8$

Medina-Elizalde, M., Burns, S. J., Polanco-Martínez, J. M., Beach, T., Lases-Hernández, F., Shen, C. C., \& Wang, H. C. (2016). High-resolution speleothem record of precipitation from the Yucatan Peninsula spanning the Maya Preclassic Period. Global and Planetary Change, 138, 93-102. https://doi.org/10.1016/j.gloplacha.2015.10.003

Medina-Elizalde, M., \& Rohling, E. J. (2012). Collapse of classic maya civilization related to modest reduction in precipitation. Science, 335(6071), 956-959. https://doi.org/10.1126/science.1216629

Neff, H., Pearsall, D. M., Jones, J. G., Arroyo de Pieters, B., \& Freidel, D. E. (2006). Climate change and population history in the Pacific Lowlands of Southern Mesoamerica. Quaternary Research, 65(3), 390-400. https://doi.org/10.1016/j.yqres.2005.10.002

Oster, J., Warken, S., Sekhon, N., Arienzo, M., \& Lachniet, M. (2019). Speleothem Paleoclimatology for the Caribbean, Central America, and North America. Quaternary, 2(1), 5. https://doi.org/10.3390/quat2010005

Pacheco-Forés, S. I., Gordon, G. W., \& Knudson, K. J. (2020). Expanding radiogenic strontium isotope baseline data for central Mexican paleomobility studies. PLoS ONE, 15(2). https://doi.org/10.1371/journal.pone.0229687

Pollock, A. L., van Beynen, P. E., DeLong, K. L., Polyak, V., Asmerom, Y., \& Reeder, P. P. (2016). A mid-Holocene paleoprecipitation record from Belize. 463, 103-111. https://doi.org/10.1016/j.palaeo.2016.09.021

Ridley, H. E., Asmerom, Y., Baldini, J. U. L., Breitenbach, S. F. M., Aquino, V. V., Prufer, K. M., Culleton, B. J., Polyak, V., Lechleitner, F. A., Kennett, D. J., Zhang, M., Marwan, N., Macpherson, C. G., Baldini, L. M., Xiao, T., Peterkin, J. L., Awe, J., \& Haug, G. H. (2015). Aerosol forcing of the position of the intertropical convergence zone since ad 1550. Nature Geoscience, 8(3), 195-200. https://doi.org/10.1038/ngeo2353

Sinclair, D. J. (2011). Two mathematical models of Mg and Sr partitioning into solution during incongruent calcite dissolution: implications for dripwater and speleothem studies. Chemical Geology.

Sinclair, D. J., Banner, J. L., Taylor, F. W., Partin, J., \& Jenson, J. (2012). Magnesium and strontium systematics in tropical speleothems from the Western Pacific. Chemical .... 
Stahle, D. W., Diaz, J. V., Burnette, D. J., Paredes, J. C., Heim, R. R., Fye, F. K., Soto, R. A., Therrell, M. D., Cleaveland, M. K., \& Stahle, D. K. (2011). Major Mesoamerican droughts of the past millennium. Geophysical Research Letters, 38(5). https://doi.org/10.1029/2010GL046472

Steponaitis, E., Andrews, A., McGee, D., Quade, J., Hsieh, Y.-T., Broecker, W. S., Shuman, B. N., Burns, S. J., \& Cheng, H. (2015). Mid-Holocene drying of the U.S. Great Basin recorded in Nevada speleothems. Quaternary Science Reviews, 127, 174-185. https://doi.org/10.1016/j.quascirev.2015.04.011

Tremaine, D. M., \& Froelich, P. N. (2013). Speleothem trace element signatures: A hydrologic geochemical study of modern cave dripwaters and farmed calcite. Geochimica et Cosmochimica Acta, 121, 522-545. https://doi.org/10.1016/j.gca.2013.07.026

Tremaine, D. M., Froelich, P. N., \& Wang, Y. (2011). Speleothem calcite farmed in situ: Modern calibration of $\delta 180$ and $\delta 13 \mathrm{C}$ paleoclimate proxies in a continuously-monitored natural cave system. Geochimica et Cosmochimica Acta, 75(17), 4929-4950. https://doi.org/10.1016/j.gca.2011.06.005

Vuille, M., Bradley, R. S., Healy, R., Werner, M., Hardy, D. R., Thompson, L. G., \& Keimig, F. (2003). Modeling $\delta 180$ in precipitation over the tropical Americas: 2. Simulation of the stable isotope signal in Andean ice cores. Journal of Geophysical Research D: Atmospheres, 108(6). https://doi.org/10.1029/2001jd002039

Wong, C. I., Banner, J. L., \& Musgrove, M. (2015). Holocene climate variability in Texas, USA: An integration of existing paleoclimate data and modeling with a new, high-resolution speleothem record. Quaternary Science Reviews, 127, 155-173. https://doi.org/10.1016/j.quascirev.2015.06.023

Wong, C. I., \& Breecker, D. O. (2015). Advancements in the use of speleothems as climate archives. Quaternary Sci Rev, 127, 1-18. https://doi.org/10.1016/j.quascirev.2015.07.019

Wright, K., Johnson, K. R., Serrato Marks, G., McGee, D., Bhattacharya, T., Goldsmith, G. R., et al. (in prep.). Precipitation in Mexico dominated by changes in Atlantic Meridional Overturning Circulation. In preparation for Science Advances. 


\title{
Chapter 2: Evidence for decreased precipitation variability in the Yucatán Peninsula during the mid-Holocene
}

\begin{abstract}
The Yucatán Peninsula has a complex hydroclimate with many proposed drivers of interannual and longer-term variability, ranging from coupled ocean-atmosphere processes to frequency of tropical cyclones. The mid-Holocene, thought to have had warmer north Atlantic sea surface temperatures, provides an interesting opportunity to test the relationship between Yucatán Peninsula precipitation and ocean temperature. Here we present a new, annually resolved speleothem record of stable isotope $\left(\delta^{18} \mathrm{O}\right.$ and $\left.\delta^{13} \mathrm{C}\right)$ and trace element $(\mathrm{Mg} / \mathrm{Ca}$ and $\mathrm{Sr} / \mathrm{Ca})$ ratios for a section of the mid-Holocene (5.2-5.7 kyr BP). A meter-long stalagmite from Río Secreto, a cave system in Playa del Carmen, Mexico, was dated using U/Th geochronology and layer counting, yielding $\sim$ decadal age uncertainty. The new proxy data were compared to a previously published late Holocene stalagmite from the same cave system, allowing us to examine changes in hydrology over time without potential inter-cave differences. The $\delta^{18} \mathrm{O}, \delta^{13} \mathrm{C}$ and trace element data consistently indicate higher mean precipitation and lower precipitation variability during the mid-Holocene compared to the late Holocene. Despite this reduced variability, spectral analysis suggests that multi-decadal precipitation variations were persistent in regional hydroclimate during the mid- and late Holocene. Wet-dry oscillations occurred in association with the higher summer solar input and higher mean precipitation of the mid-Holocene, though with reduced amplitude compared to the late Holocene. We therefore conclude that the Yucatán Peninsula is susceptible to dry periods across different climate mean states.
\end{abstract}

\section{Introduction}

The Yucatán Peninsula (YP) harbors diverse ecosystems, including the Mesoamerican barrier reef and tropical rainforests, and has been inhabited by Maya societies for thousands of years. Biological systems and human societies in the region developed under limited surface and groundwater availability and have therefore been vulnerable to hydroclimate extremes. There has been extensive research on the potential drivers of YP climate variability during the Common Era, 2,000 years before present (yr BP) to present, and on the role of drought in the decline of Maya civilization during the Preclassic (droughts at $\sim 180$ and 240 CE) and Terminal Classic Periods (750-950 CE) (e.g. Curtis et al., 1996; Hodell et al., 1995; Medina-Elizalde et al., 2010, 2016a).

Climate simulations and paleoclimate records suggest that late Holocene precipitation in the YP was linked to North Atlantic climate variability. Potential controls on precipitation amount include changes in sea surface temperature (SST), sea level pressure (SLP) 
(Bhattacharya et al., 2017), tropical cyclone variability (Frappier et al., 2007, 2014; MedinaElizalde et al., 2016a), and the mean position of the Intertropical Convergence Zone (ITCZ) (e.g. Bush et al., 2009; Lechleitner et al., 2017; Pollock et al., 2016; Ridley et al., 2015). These climate variations are likely linked, further complicating diagnostics (McGee et al., 2014). YP precipitation variability also suggests a link with El Niño-Southern Oscillation (ENSO) in the Pacific (Frappier et al., 2014; Giannini et al., 2000, Lachniet et al., 2017; Medina-Elizalde et al., 2016a, 2016b, 2017; Metcalfe et al., 2009; Pollock et al., 2016; Stahle et al., 2012).

However, the majority of the paleoclimate records from the YP are confined to the late Holocene, and do not extend into the mid- or early Holocene. The mid-Holocene is of particular interest to investigate the role of external forcing on hydroclimate variability in the Caribbean region. During the mid-Holocene, solar radiation was higher in the Northern hemisphere (NH) during the boreal summer relative to the late Holocene and present (Hoddell et al., 1995; Laskar et al., 2004) and ENSO variability was markedly decreased (Carré et al., 2014; Chen et al., 2016; Emile-Geay et al., 2016). Limited data on Atlantic and Caribbean sea surface temperatures are available for this time period, but based on increased $\mathrm{NH}$ summer radiation, it is possible that there was stronger seasonality and higher summer SSTs in the North Atlantic and Caribbean. Given modern connections between the North Atlantic and Caribbean hydroclimate (e.g. Bhattacharya et al., 2017) we expect that the mid-Holocene was wetter and less variable in precipitation than the late Holocene or the present.

The existing paleoclimate records in the YP are based on proxy data from various archives, including cave speleothems (e.g. Akers et al., 2016; Frappier et al., 2014; Pollock et al., 2016) and lake, sinkhole, wetland, and swamp sediment cores (Curtis et al., 1996; Douglas et al., 2015; Guttierez-Ayala et al., 2012; Hodell et al., 2005; Metcalfe et al., 2009; Rosenmeier et al., 2002; Roy et al., 2017). Interpretations of these paleoclimate records do not offer a consensus regarding the magnitude and frequency of precipitation variability and underlying drivers during the Holocene. Discrepancies among available paleoclimate records do not indicate that these records are erroneous; instead, they likely reflect climatological differences among locations, chronological uncertainties, differences in the temporal resolution, and the complexity inherent in using geochemical proxies to infer past climates. With few exceptions (Kennett et al., 2012; Medina-Elizalde et al., 2010, Richey et al., 2015, Ridley et al., 2015), most available paleoclimate records do not have enough temporal resolution to investigate interannual to 
decadal hydroclimate variability in the region, and most high-resolution studies are limited to the Late Holocene. Finally, no existing studies on stalagmite geochemical records from the YP have compared multiple stalagmite specimens from the same cave. Therefore, there is a need for climate archives that come from the same location, use the same proxies, and have high temporal resolution to investigate changes in climate variability through the Holocene.

In order to refine our understanding of hydroclimate variability in the YP and its underlying drivers during the mid-Holocene, we present stalagmite $\delta^{18} \mathrm{O}, \delta^{13} \mathrm{C}, \mathrm{Mg} / \mathrm{Ca}$ and $\mathrm{Sr} / \mathrm{Ca}$ records spanning the interval between 5.2 and $5.7 \mathrm{kyr}$ before present (BP). The stalagmite we use, named RS1, was collected in April 2013 from an isolated chamber in the Río Secreto Cave system, located in the northeastern YP. An extensive drip water monitoring system was installed in 2014; RS1 was sampled closest to Drip Station A referenced in Lases-Hernandez et al. (2019). $\mathrm{RS} 1$ is a $\sim 1 \mathrm{~m}$ tall calcite stalagmite, which was partially collapsed at the time of collection. It presents visually distinct lamination, allowing development of an age model based on laminae counting and $\mathrm{U}$-series dating (see Methods). Stalagmite $\delta^{18} \mathrm{O}$ and $\delta^{13} \mathrm{C}$ have often been used to infer changes in precipitation in this region (e.g. Medina-Elizalde et al., 2010; Pollock et al., 2016; Ridley et al., 2015), while $\mathrm{Mg} / \mathrm{Ca}$ and $\mathrm{Sr} / \mathrm{Ca}$ have not been examined previously in the YP, but have been interpreted to reflect precipitation amount in other settings.

This study examines the new stalagmite record in comparison to another stalagmite-based precipitation record, known as Itzamna, from the same well-studied cave, spanning $\sim 3$ to $1.6 \mathrm{kyr}$ BP (Medina-Elizalde et al., 2016a). Stalagmite proxy records from the same location allow us to contrast inferred mid- and late Holocene hydroclimate variability, and minimize the uncertainty associated with comparing stalagmite proxy records from different locations and cave environments.

\subsection{Regional climate}

The YP experiences a strong seasonality in precipitation amount (Figure 1). The rainy season occurs in the summer, often interrupted by decreased rainfall in July or August (Karmalkar et al., 2011; Lases-Hernandez et al., 2019; Muñoz et al., 2008). About 70\% of annual rainfall occurs between June and November (Medina-Elizalde et al., 2016b; Figure 1). Maximum precipitation often occurs in September, when the ITCZ is at its northernmost position and Atlantic tropical cyclone frequency peaks (Kovacs et al., 2017; Lases-Hernandez et al., 2019). Strong easterly winds, known as the Caribbean Low-Level Jet (CLLJ), bring moisture from the 
warm Caribbean Sea to the YP (Muñoz et al., 2008); if enhanced, the CLLJ drives increased moisture transport and convergence in the region (Karmalkar et al., 2011; Mestas-Nuñez et al., 2007; Muñoz et al., 2008;). The large-scale structure of the vertically-integrated water vapor fluxes associated with the CLLJ links the Caribbean and Gulf of Mexico regions to climate regimes in the US, particularly during boreal summer (Mestas-Nuñez et al., 2007; Muñoz et al., 2008). We note that historical precipitation variability in the YP region is linked to that of the broader Caribbean region, particularly the northern sector, as indicated by spatial-temporal correlation analyses of instrumental precipitation records (e.g. Medina-Elizalde et al., 2017).

\subsection{Climate proxies}

Stalagmite $\delta^{18} \mathrm{O}$ records in Mesoamerica, including the YP, are interpreted to reflect changes in precipitation amount (e.g. Akers et al., 2016; Lachniet et al., 2017; Medina-Elizalde et al., 2016a, 2016b), with more negative $\delta^{18} \mathrm{O}$ values indicating increased precipitation, as expected from an amount effect, or the empirical relationship between precipitation amount and $\delta^{18} \mathrm{O}$ composition observed in the tropics from seasonal to interannual timescales (Burns et al., 1998; Dansgaard, 1964; Lases-Hernandez et al., 2019; Vuille et al., 2003). Changes in $\delta^{13} \mathrm{C}$ in stalagmites reflect a number of local processes associated with the soil cover, epikarst and vadose zone (Genty et al., 2006). Some of the most common controls include the ratio of C3 to C4 vegetation above the cave (Burns et al., 2016; Dorale et al., 1998; Webb et al., 2004;) and the amount of degassing in the vadose zone (Lachniet et al., 2004). Rainfall amount can influence drip water $\delta^{13} \mathrm{C}$ (and therefore stalagmite $\delta^{13} \mathrm{C}$ ) by affecting soil moisture and organic matter production, bedrock dissolution, degassing, and prior calcite precipitation (PCP) (Genty et al., 2006; Ridley et al., 2015; Wong and Breecker, 2015).

In low-latitude caves where the overlying vegetation is expected to remain relatively stable over time, stalagmite $\delta^{13} \mathrm{C}$ variability can reflect precipitation amount, as observed in Belize (Ridley et al., 2015). Low precipitation enhances PCP, increases bedrock carbon contributions and decreases soil bio-productivity, all ultimately increasing drip water and stalagmite $\delta^{13} \mathrm{C}$ (e.g. Pollock et al., 2016; Ridley et al., 2015). In the YP, where the type of vegetation is also expected to have remained relatively constant, particularly during the midHolocene before extensive human activity, stalagmite $\delta^{13} \mathrm{C}$ could reflect precipitation amount. 
Although stalagmite $\delta^{18} \mathrm{O}$ and $\delta^{13} \mathrm{C}$ records have been widely interpreted as hydroclimate proxies, they are not without complexities. Stalagmite $\delta^{18} \mathrm{O}$ can be influenced by changes in moisture source and upstream water vapor history. Similarly, stalagmite $\delta^{13} \mathrm{C}$ can be impacted by soil and karst processes not directly related to precipitation variability (Genty et al., 2001; Hellstrom et al., 1998). Moreover, both $\delta^{18} \mathrm{O}$ and $\delta^{13} \mathrm{C}$ can also be affected by kinetic fractionation, especially in low humidity environments. Despite these potentially complicating issues, previous studies in the YP and Belize present multiple lines of evidence that stalagmite $\delta^{18} \mathrm{O}$ and $\delta^{13} \mathrm{C}$ can record local and regional precipitation amount (Medina-Elizalde et al., 2010, 2016a, 2016b, 2017; Pollock et al., 2016; Ridley et al., 2015). We analyze $\mathrm{Mg} / \mathrm{Ca}$ and $\mathrm{Sr} / \mathrm{Ca}$ ratios to examine their magnitude and frequency variability and to test interpretations from the more conventional $\delta^{18} \mathrm{O}$ and $\delta^{13} \mathrm{C}$ records. This is the first study that examines $\mathrm{Mg} / \mathrm{Ca}$ and $\mathrm{Sr} / \mathrm{Ca}$ ratios in a stalagmite from the YP region.

Several stalagmite analyses in other locations have applied $\mathrm{Mg} / \mathrm{Ca}$ and $\mathrm{Sr} / \mathrm{Ca}$ for hydroclimate reconstruction (e.g. Cruz et al. 2017; Fairchild et al., 2001; Lewis et al., 2011; Roberts et al., 1998; Steponaitis et al., 2015). Trace element to calcium ratios can track PCP and/or water-rock interactions, which change based upon soil and water conditions in the local environment (e.g. Cruz et al., 2017; Fairchild et al., 2000, 2001; Sinclair et al., 2012). In drier conditions, water moves more slowly through the karst above a cave, so it has more time to degas and become saturated with calcite (Tremaine and Froelich, 2013). During PCP, Mg and Sr are preferentially excluded from the calcite crystal lattice, so $\mathrm{Mg} / \mathrm{Ca}$ and $\mathrm{Sr} / \mathrm{Ca}$ ratios in groundwater increase with PCP (Fairchild et al., 2000). Non-PCP interactions between water and host rock, also referred to as calcite recrystallization, can also occur in the karst, especially when water residence time is high during dry periods. The chemical signature of recrystallization is similar to that of PCP, but with a different relationship between $\mathrm{Mg} / \mathrm{Ca}$ and $\mathrm{Sr} / \mathrm{Ca}$ (Sinclair et al., 2012). Therefore, $\mathrm{Mg} / \mathrm{Ca}$ and $\mathrm{Sr} / \mathrm{Ca}$ in stalagmites provide an estimate of aquifer recharge and water availability that can serve as an independent proxy, and provide a method to examine whether stalagmite $\delta^{18} \mathrm{O}$ primarily reflects changes in local moisture availability (Tremaine \& Froelich, 2013). 

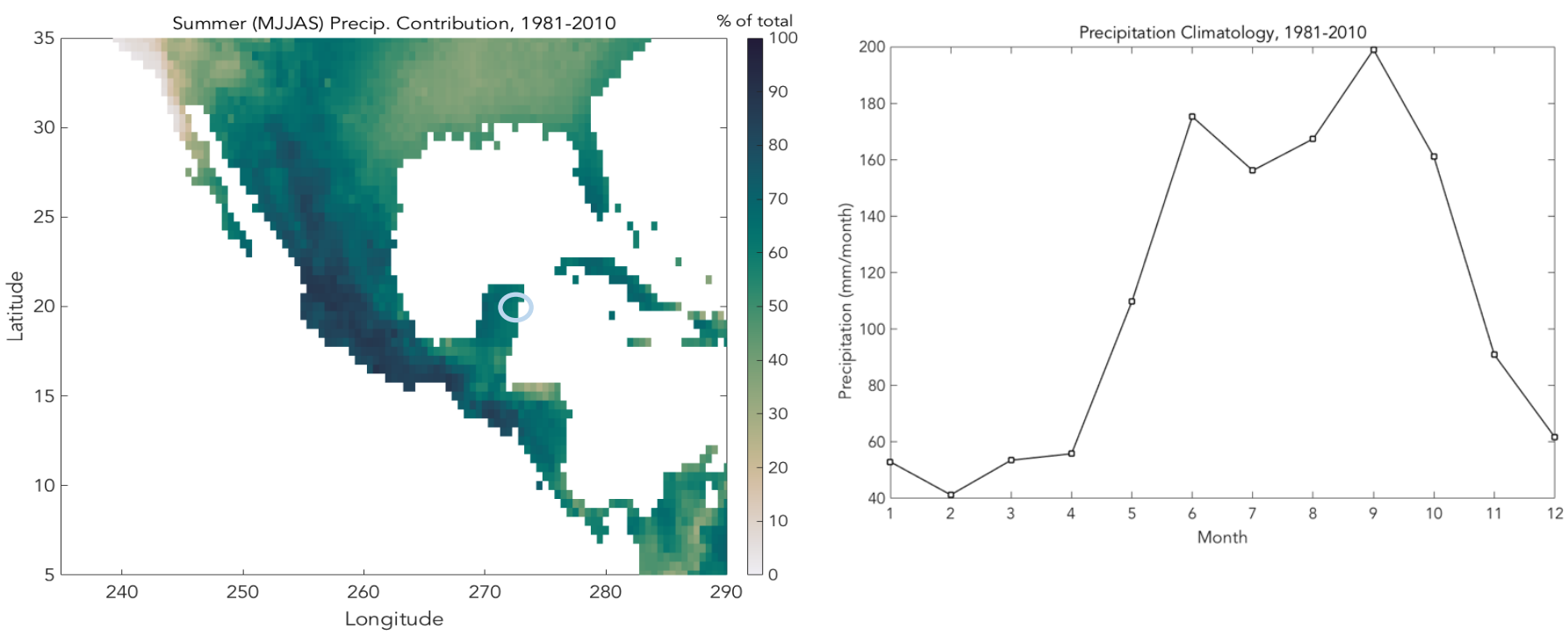

Figure 1. Seasonality of precipitation at the Yucatan Peninsula (YP) and surrounding area; all rainfall data are from the University of Delaware Terrestrial Air Temperature and Precipitation dataset (Willmott \& Matsuura, 2001). Left: Percentage of total rainfall from the summer wet season (MJJAS); blue circle indicates the location of Río Secreto Cave, our study site. Right: monthly precipitation from the grid point closest to Río Secreto (Willmott \& Matsuura, 2001).

\section{Methods}

\subsection{Regional setting and cave system}

We collected the stalagmite outside the city of Playa del Carmen, in the northeast YP $\left(20^{\circ} 35.244^{\prime} \mathrm{N}, 87^{\circ} 8.042^{\prime} \mathrm{W}, 10-20 \mathrm{~m}\right.$ above sea level). The Río Secreto Cave (RS) entrance is about $5 \mathrm{~km}$ from the Caribbean coast; therefore, the locale has a strong maritime influence from the Caribbean.

Temperature and relative humidity in RS have been monitored continuously since 2014. Annual mean temperature in the collection chamber varied by $0.1{ }^{\circ} \mathrm{C}$, from 24.6 to $24.7^{\circ} \mathrm{C}$ (Medina-Elizalde et al., 2016b; Lases-Hernandez et al., 2019). The steady temperature limits the effect of calcification temperature on stalagmite $\delta^{18} \mathrm{O}$ (hereafter $\delta^{18} \mathrm{O}_{\text {calcite) }}$. RS has a relative humidity of $99.6 \pm 0.9 \%$ throughout the year (Medina-Elizalde et al., 2016b; Lases-Hernandez et al., 2019). Three years of drip water $\delta^{18} \mathrm{O}\left(\delta^{18} \mathrm{O}_{\text {drip }}\right)$ monitoring at 16 drip sites indicate that $\delta^{18} \mathrm{O}_{\text {drip }}$ reflects the $\delta^{18} \mathrm{O}$ composition of precipitation $\left(\delta^{18} \mathrm{O}_{\text {precip }}\right)$, and that evaporation does not influence $\delta^{18} \mathrm{O}_{\text {drip. }}$. The average $\delta^{18} \mathrm{O}_{\text {drip }}$ is $-3.9 \pm 0.2 \%$ ( $( \pm 2 *$ standard error, hereafter $2 \mathrm{SE} ; \mathrm{n}=$ 1043 drip samples collected over 3 years), and the amount-weighted $\delta^{18} \mathrm{O}_{\text {precip }}$ is $-3.7 \pm 0.5 \%$ o ( $=36$ monthly rainfall samples; arithmetic mean $\delta^{18} \mathrm{O}_{\text {precip }}=-2.6 \pm 0.5 \%$; $\pm 2 \mathrm{SE}$ ) (Lases- 
Hernandez et al., 2019). Therefore, the cave drip water accurately records regional $\delta^{18} \mathrm{O}_{\text {precip }}$ within error. Rainfall infiltration rates vary, with some drip sites showing increased discharge immediately after rainfall events and others lagging by weeks to three months (Lases-Hernandez et al., 2019).

Drip water samples closest to the RS1 collection site show muted 2\%o intra-annual (seasonal) variability in $\delta^{18} \mathrm{O}$ (Lases-Hernandez et al., 2019), and annual mean $\delta^{18} \mathrm{O}_{\text {drip }}$ similar to the amount-weighted annual mean $\delta^{18} \mathrm{O}_{\text {precip }}$, which suggests that this chamber has a large reservoir with a mixture of seasonal and seepage flow that averages approximately one year of rainfall accumulation (Lases-Hernandez et al., 2019); most recently, the residence time is estimated to be 4 to 15 months (Lases-Hernandez et al., 2020). Therefore, this study focuses on variability at annual or greater scales. The stalagmite was sampled for proxies with the aim of producing annual resolution data.

\subsection{U/Th dating, age modeling and microstratigraphy}

The age model for RS1 is constrained by U/Th dating of 15 horizons distributed throughout the length of the stalagmite, performed at MIT (Figure 2). Analyses included replicates (Figure 2). Dating samples weighing $\sim 150 \mathrm{mg}$ were drilled with a vertical mill. Powders were dissolved and spiked with a ${ }^{229} \mathrm{Th}-{ }^{233} \mathrm{U}-236 \mathrm{U}$ tracer. Based on methods detailed in Edwards et al. (1987), U and Th were isolated using co-precipitation with Fe oxyhydroxides, and eluted using columns with AG1-X8 resin. A total procedural blank was included with each set of dating samples. U and Th fractions were measured on a Nu Plasma II-ES MC-ICP-MS, as described in Burns et al. (2016). We used an initial ${ }^{230} \mathrm{Th} /{ }^{232} \mathrm{Th}$ value of $4.4 \pm 2.2$ for detrital correction.

Five of the 15 total dates were not included in the final age model due to low reproducibility, location outside hiatuses, or proximity to possible dissolution features (Supplemental Information). Replicates from the same depth were discarded if they did not overlap within $2 \mathrm{SD}$, and samples within $10 \mathrm{~mm}$ of a possible dissolution feature were not included.

Age-depth relationships were calculated with the COPRA program (Breitenbach et al., 2012) in MATLAB (version R2018b). The age-depth model was based on 2000 Monte Carlo simulations of $10 \mathrm{U} / \mathrm{Th}$ dates. The median age model was selected instead of the mean to reduce the risk of extreme models having an outsized impact on the final age model. We calculated 
upper and lower bounds of the $95 \% \mathrm{CI}$, but we are only using the median age-depth model for our analysis. The median age model and the $95 \% \mathrm{CI}$ limits all fall within the 2SD uncertainty of each $\mathrm{U} / \mathrm{Th}$ date.

Age modeling results showed that the stalagmite spans $528 \pm 76$ years and visual counts of the same vertical extent yielded $482 \pm 38$ layers (mean \pm 2 SD of multiple counts by GSM and Gabriela Cazares). The U/Th age and layer count overlap within uncertainty, so we established a layer count-enabled age-depth model. We used two dates (one from the top and one from the bottom) as markers of absolute age, then used layer counts between other dates points to measure relative change in age. We used the date second from the bottom as an anchor (instead of the date closest to the bottom) because of the potential shift in growth rate observed from age-depth modeling. With this method, we generated a simplified age-depth model based on a cubic function $\left(r^{2}>0.99\right.$; Figure 2$)$ which is used to calculate ages for the time series of geochemical proxies. The age depth model without layer counting is shown in the Appendix.

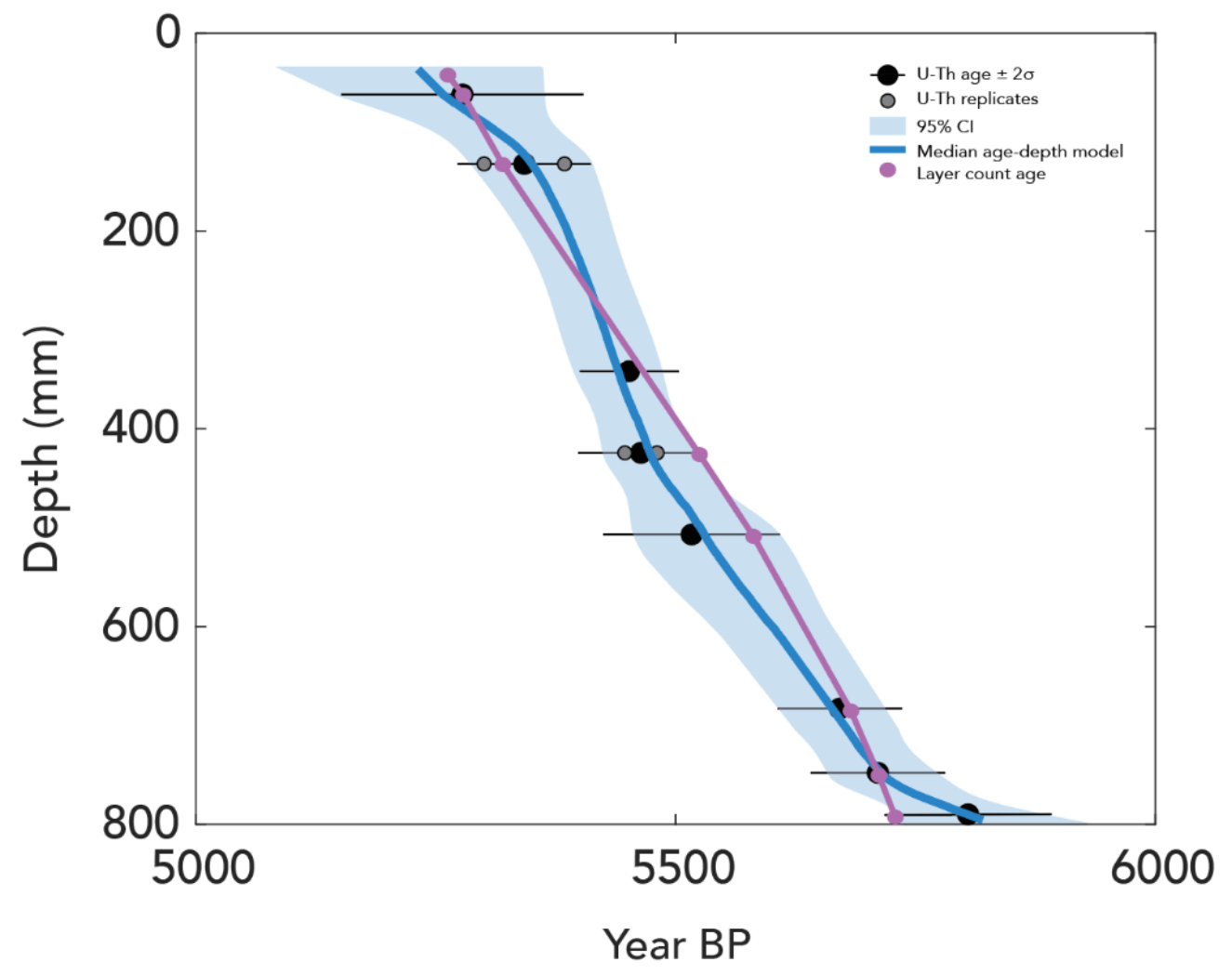

Figure 2. Age-depth relationship for RS1 based on Monte Carlo modeling of ten U/Th dating horizons and layer counting. The median and $95 \%$ confidence interval age models used U/Th dates only; the layer count-enabled model is shown in purple, and is used for the time series plots in subsequent figures. 
RS1 shows a high deposition rate with visually distinct $\sim 2 \mathrm{~mm}$-thick layers throughout the stalagmite, likely reflecting annual deposition (Figure 2). The layers were distinct enough to count and measure in photographs or hand sample, allowing for counting without microscopy or thin sections.

At the bottom of the stalagmite ( $794 \mathrm{~mm}$ from the top), there is a $\sim 50 \mathrm{~mm}$-long, relatively dark region that looks more similar to the outer crust than to the rest of the stalagmite (Figure 3C). There are no visible layers within the region, suggesting that the layering was dissolved and recrystallized with newer crust. XRD analysis showed that this region is calcite with added silica (Appendix). Qualitatively, this region is denser and harder, consistent with the presence of minerals harder than calcite. RS1 was found partially collapsed, so we infer that this dark area is a diagenetically altered segment. Both the dark region and the layers below were not included in this study.

Visual inspection revealed a potential hiatus near the top of the sample (Figure 3D), visible as a color change in the calcite and a $2 \mathrm{~mm}$-thick brown layer. Therefore, the region above the deposited dark material (top - $23 \mathrm{~mm}$ from top) was not used in climate analysis or age-depth calculations. After these regions were excluded, the useable region of RS1 spans $455 \pm$ 38 years (5720-5266 yr BP; 2SD uncertainty based on layer counting). This age is still within 2SD uncertainty of the original age model without layer counting. 

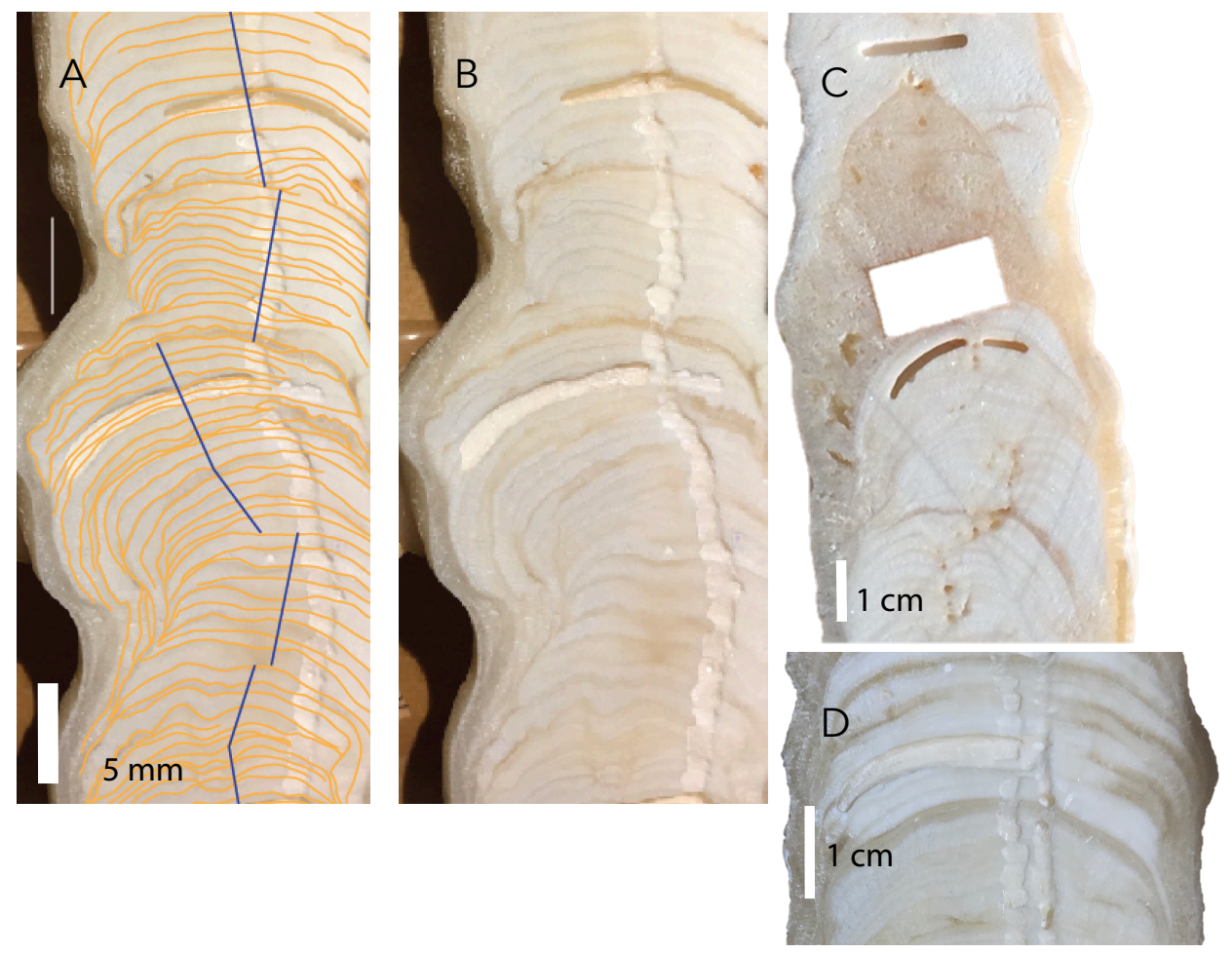

E

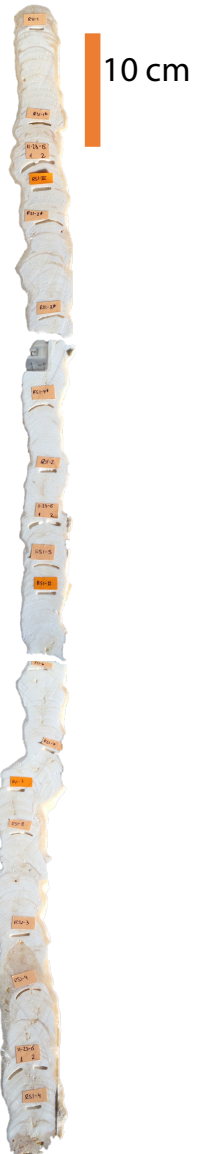

Figure 3. Images of RS1, a meter-long, mid-Holocene stalagmite from the YP A. Detail of mmscale layers. Individual layers (orange) are deposited from bottom to top, with visible changes in thickness over time and changes in hypothesized growth axes (straight lines). B. Same as A, without annotations. C. Relatively dark and porous region without visible layers (surrounding the white rectangle); D. Hypothesized hiatus near the top of RS1. E. Full stalagmite.

\subsection{Stable isotope measurements $\left(\delta^{18} \mathrm{O}\right.$ and $\delta^{13} \mathrm{C}$ )}

Calcite samples for stable isotope analysis were drilled at a $\sim 2 \mathrm{~mm}$ resolution in a continuous track parallel to the growth axis ( $\mathrm{n}=342$ samples). The $\delta^{18} \mathrm{O}$ and $\delta^{13} \mathrm{C}$ analyses were carried out using a Thermo Scientific MAT253 Stable Isotope Ratio Mass Spectrometer online coupled to a Kiel IV at University of California Santa Barbara. About 40-50 $\mu$ g of each sample was reacted using $105 \%$ phosphoric acid addition. The evolving $\mathrm{CO}_{2}$ was cryogenically cleaned before introduction into the mass spectrometer. The $\delta^{18} \mathrm{O}$ and $\delta^{13} \mathrm{C}$ data are reported on the Pee Dee Belemnite (PDB) scale. The precision of the $\delta^{18} \mathrm{O}$ and $\delta^{13} \mathrm{C}$ analysis, assessed by analyzing NBS 19 standards, is $\pm 0.07 \%$ and $\pm 0.05 \%$ (2SE), respectively. 


\section{$2.4 \mathrm{Mg} / \mathrm{Ca}$ and $\mathrm{Sr} / \mathrm{Ca}$ measurements}

Additional samples (weight $=\sim 2 \mathrm{mg}$ ) were drilled for trace element analysis at a $\sim 2 \mathrm{~mm}$ resolution in similar locations as the stable isotope powders (Section 2.3). Each sample was dissolved and diluted with 3\% nitric acid. Standards with similar $\mathrm{Mg} / \mathrm{Ca}$ and $\mathrm{Sr} / \mathrm{Ca}$ ratios and concentrations were prepared using single-element standards. Analyses of $\mathrm{Mg}, \mathrm{Sr}$, and $\mathrm{Ca}$ were performed at MIT on an Agilent 7900 ICP-MS in no-gas mode. Data were corrected for blank intensities, isotopic abundances, and instrumental drift. Relative deviation in standards during one day of analysis averaged 4\% ( $n=5$ standards per day) after these corrections. Replicate runs of identical solutions on different days also varied by an average of $4 \%$. Replicate powders drilled from the same depth, but at different distances from the growth axis, varied by $1 \%$ or less in both $\mathrm{Mg} / \mathrm{Ca}$ and $\mathrm{Sr} / \mathrm{Ca}$. All future references to trace elemental ratios in this work will be referring to $\mathrm{Mg} / \mathrm{Ca}$ and $\mathrm{Sr} / \mathrm{Ca}$.

\subsection{Data analysis}

We used principal component (PC) analysis (based on all four geochemical proxy records, normalized and resampled to annual resolution) to find 4 PCs that explain $99 \%$ of the variance in the geochemical data ( $88 \%$ of the variance within PCs 1-3). We then analyzed the periodicity of the PCs using the periodogram function in MATLAB (version R2018b). We determined the statistical significance of periods using a null model with no true periodicity; we repeatedly ( $\mathrm{n}=2000$ iterations) generated sets of four annual "records" with red noise (each record matching the variance of one proxy), then extracted the first PC from each set and normalized it. This is similar to checking the significance with an AR1 noise signal (Feng et al., 2014; Pollock et al., 2016), but with more iterations. The 2000 noise-based PCs were analyzed for periodicity, including $80 \%, 90 \%$, and $95 \%$ confidence intervals (CI), and compared to the real PCs. Any peaks in spectral power above the $90 \%$ CI line are considered significant.

We also used Spearman's rank correlation, a non-parametric correlation analysis, to test for relationships between the proxies. We used a two-tailed correlation and $\mathrm{p}$-values $<0.05$ were considered significant. The rationale behind using Spearman's rank correlation instead of a parametric correlation analysis, like Pearson's correlation coefficient, was to remove the assumption of a linear relationship between the proxies. Instead, Spearman's $\rho$ measures monotonic relationships. A monotonic relationship is more likely than a linear relationship between geochemical proxies controlled by different physical mechanisms, even if they are all 
controlled (at a high level) by hydroclimate; in other words, we expect both $\delta^{18} \mathrm{O}$ and $\mathrm{Mg} / \mathrm{Ca}$ to increase with drying, but we do not expect $\mathrm{Mg} / \mathrm{Ca}$ to increase linearly with $\delta^{18} \mathrm{O}$.

\section{Results}

\subsection{U/Th dating and age model development}

\subsubsection{Initial dating analysis}

This stalagmite has precise age control, with age model uncertainty substantially lower than those found in nearby stalagmites of similar age due to its low detrital Th content (e.g. Akers et al., 2016; Pollock et al., 2016; Appendix 2). Therefore, RS1 and Itzamna are the oldest stalagmite records from the YP with dating errors $<100$ years (Medina-Elizalde et al., 2017).

\subsection{Stable isotopes}

\subsubsection{Comparison to modern drip water}

We sampled RS1 continuously at $2 \mathrm{~mm}$ resolution ( $\mathrm{n}=342$ samples) in a region of the speleothem modeled to span 455 years, meaning that each sample averaged $\sim 1.3$ years; all proxy data were resampled to annual resolution to remove potential effects of sampling frequency and variable growth rate. Mean $\delta^{18} \mathrm{O}_{\text {calcite was }}-5.5 \pm 0.047 \%$ and mean $\delta^{13} \mathrm{C}_{\text {calcite }}$ was $-9.2 \pm 0.091 \%$ $(\mathrm{n}=455$ points; mean $\pm 2 \mathrm{SE})$. All subsequent data are reported at resampled resolution.

The average modern $\delta^{18} \mathrm{O}_{\text {drip }}$ in the RS cave system is $-3.9 \pm 0.2 \%$ (VSMOW; $\pm 2 \mathrm{SE}$ ). Using the Tremaine et al. (2011) equation for equilibrium fractionation and a temperature of $24.5^{\circ} \mathrm{C}$, we calculate that equilibrium precipitation of calcite would yield $\delta^{18} \mathrm{O}_{\text {calcite }}=-4.8 \%$. This value overlaps with $\delta^{18} \mathrm{O}_{\text {calcite }}$ in the late Holocene stalagmite (Itzamna $\delta^{18} \mathrm{O}_{\text {calcite }}=-4.8 \pm 0.1 \%$; mean $\pm 2 \mathrm{SE}$ ) within error, suggesting equilibrium precipitation.

For a back of the envelope calculation of potential drip water composition in the midHolocene, we assume that no change in calcification temperature (i.e. mean cave air temperature was still $\sim 24.5^{\circ} \mathrm{C}$ ). The reversed Tremaine et al. (2011) equilibrium calculation, using $\delta^{18} \mathrm{O}_{\text {calcite }}=$ $-5.5 \%$, suggests $\delta^{18} \mathrm{O}_{\text {drip }}$ would have been approximately $-4.6 \%$. This more negative value (in comparison to modern drip water, -3.9\%; Lases-Hernandez et al., 2019) supports the hypothesis that the mid-Holocene was wetter.

\subsubsection{Timeseries analysis}


$\delta^{18} \mathrm{O}_{\text {calcite }}$ and $\delta^{13} \mathrm{C}_{\text {calcite }}$ are significantly correlated with each other in RS1 (Figures 4 and $5 ; \rho=0.507, \mathrm{p}<<0.001)$. Although some research has linked covariation in $\delta^{18} \mathrm{O}$ and $\delta^{13} \mathrm{C}$ to kinetic fractionation (e.g. Lachniet et al., 2004), previous work in this cave found that kinetic fractionation was not significant and that relative humidity is near $100 \%$ throughout the year (Lases-Hernandez et al., 2019; Medina-Elizalde et al., 2016a); therefore, we assume that both $\delta^{18} \mathrm{O}_{\text {calcite }}$ and $\delta^{13} \mathrm{C}_{\text {calcite }}$ primarily reflect hydrologic variability.
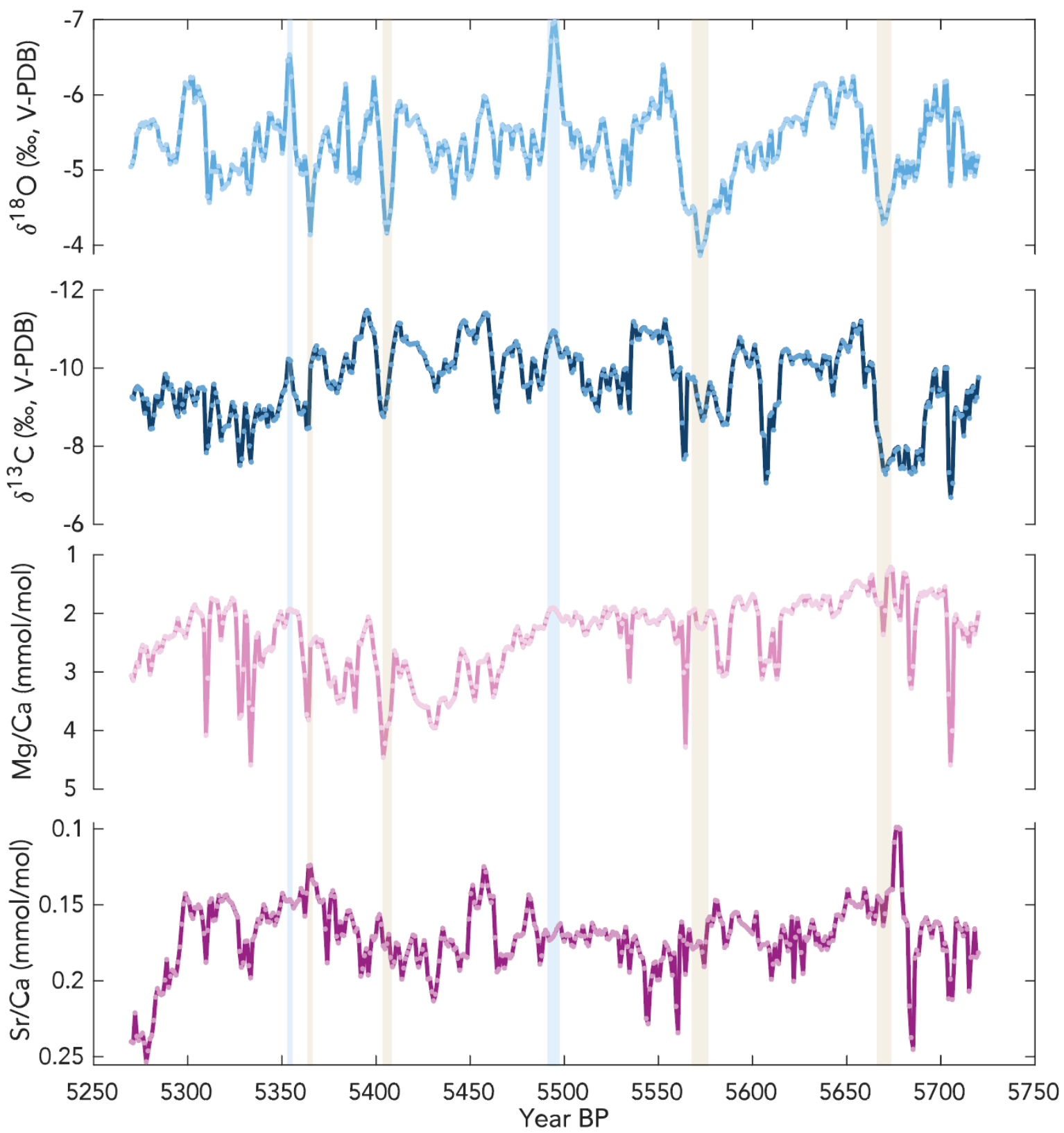

Figure 4. $\delta^{18} \mathrm{O}, \delta^{13} \mathrm{C}, \mathrm{Mg} / \mathrm{Ca}$ and $\mathrm{Sr} / \mathrm{Ca}$ data for the growth period of RS1. Vertical bars highlight periods with $\delta^{18} \mathrm{O}$ values at least 2SD greater than (tan) or less than (blue) the mean. 

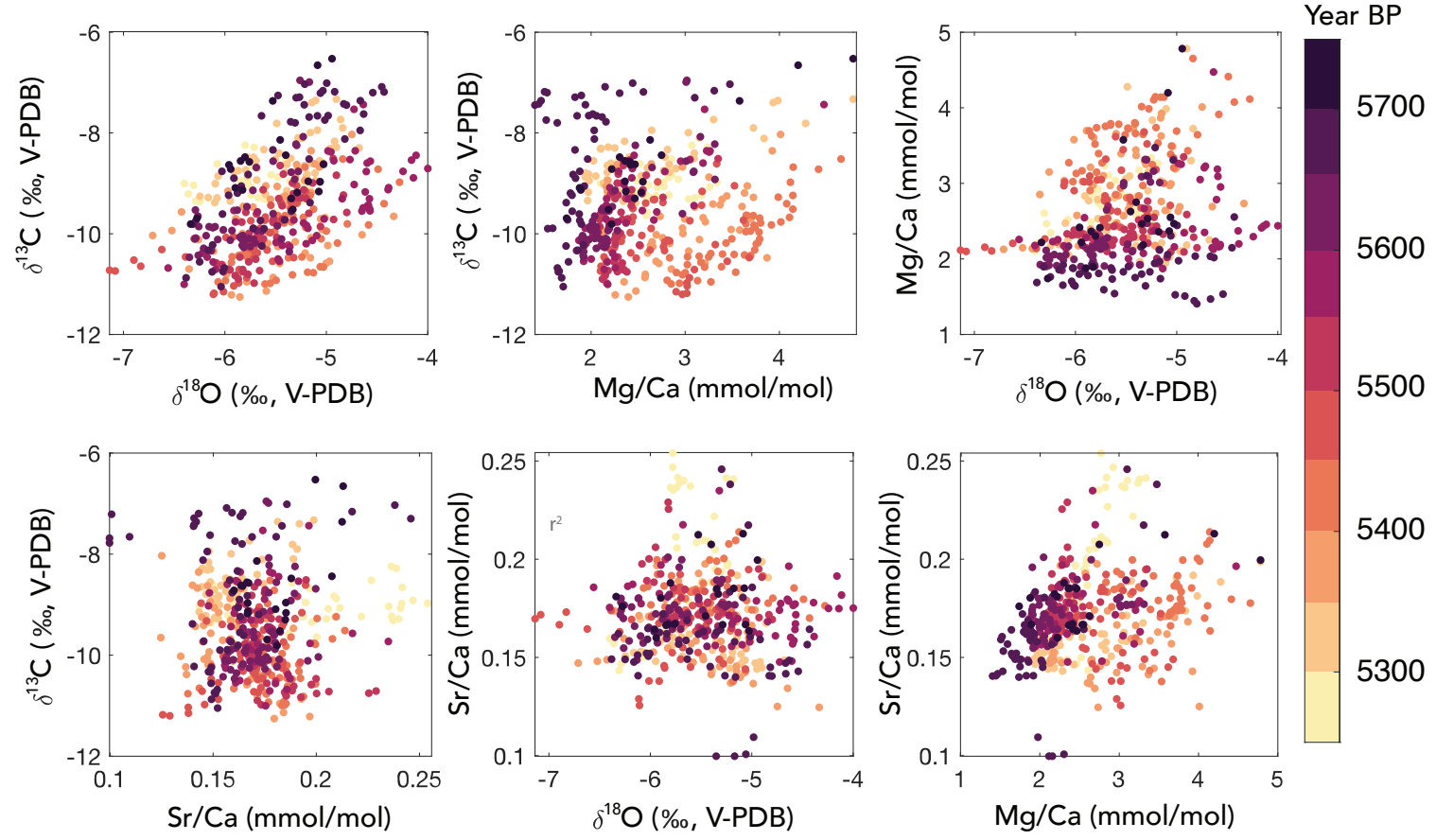

$\triangle p<0.01$
$\triangle 0.01<p<0.05$

Spearman's Rank $\rho$ in 50-year-long windows

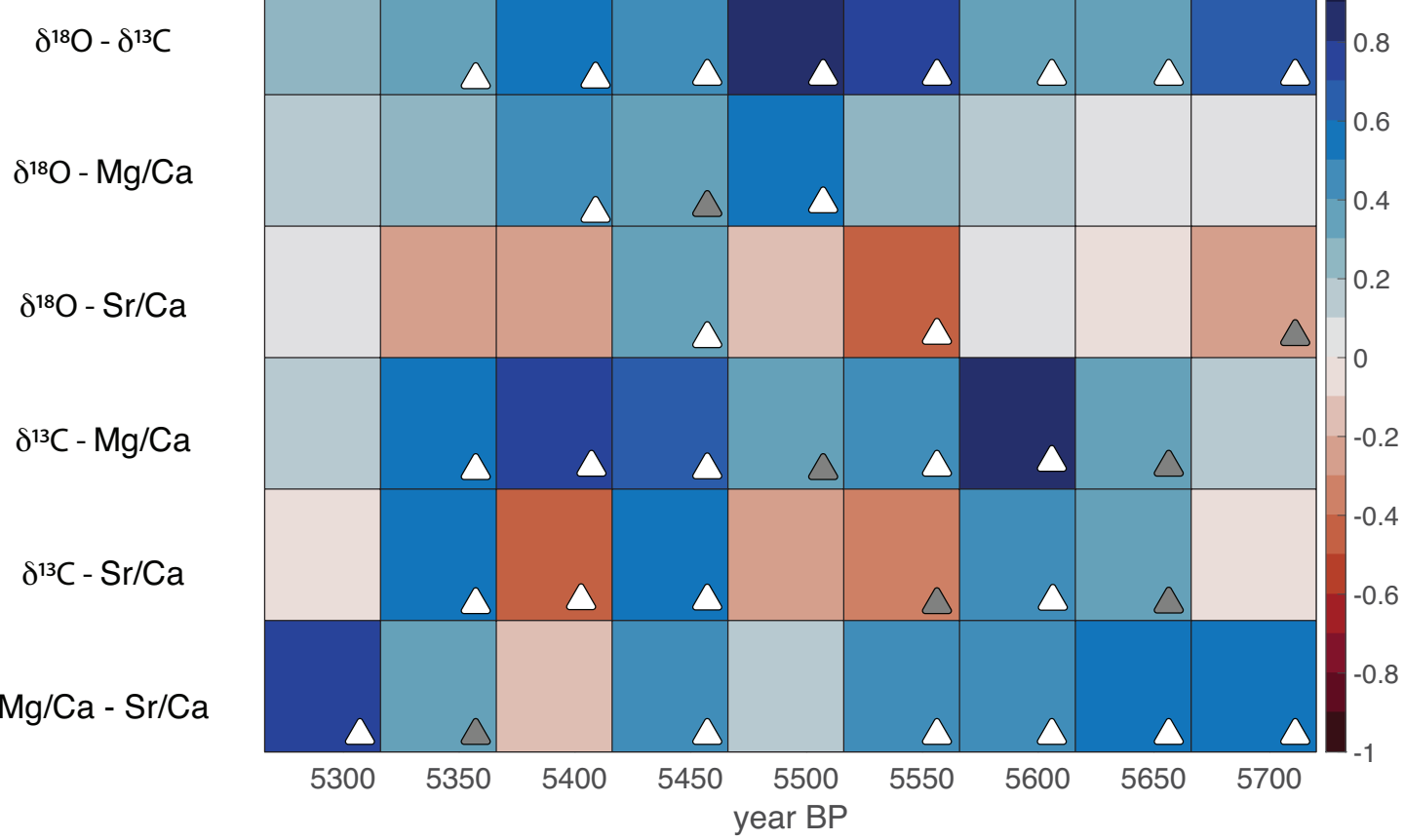

Figure 5. Top: Cross plots of trace element to calcium ratios and stable isotope data measured in RS1. All data have been resampled to annual resolution to remove sampling bias and are colored according to their age. Bottom: Correlation coefficient $(\rho)$ for Spearman's rank correlation tests on 50-year-long windows. 


\subsection{Trace elements}

Our results show that mean mid-Holocene $\mathrm{Mg} / \mathrm{Ca}$ was $2.6 \pm 0.060 \mathrm{mmol} / \mathrm{mol}$ and $\mathrm{Sr} / \mathrm{Ca}$ was $0.17 \pm 0.0021 \mathrm{mmol} / \mathrm{mol}( \pm 2 \mathrm{SE})$. Broadly speaking, the two records have a similar shape, but behave somewhat differently at high resolution, yielding a low statistical correlation. More quantitatively, Spearman's rank correlations showed a weak but significant correlation between

$\mathrm{Mg} / \mathrm{Ca}$ and $\mathrm{Sr} / \mathrm{Ca}$ data $(\rho=0.34, \mathrm{p}$-value $<<0.01$; Figure 5), meaning that $\mathrm{Mg}$ and $\mathrm{Sr}$ share some common controls. The youngest 50 years have the highest correlation $(\rho=0.76, p$-value $<<$ 0.01 ), perhaps due to their synchronous increase toward higher values during that time period (Figure 4).

There is also low but significant correlation between $\mathrm{Mg} / \mathrm{Ca}$ and $\delta^{18} \mathrm{O}_{\text {calcite }}(\rho=0.25$, $\mathrm{p}$-value $<<0.01$ ), but $\delta^{13} \mathrm{C}$ and $\mathrm{Mg} / \mathrm{Ca}$ had no significant correlation in the overall record $(\rho=0.08, \mathrm{p}-$ value $=0.07)($ Figure 5$)$. Regressions between $\mathrm{Sr} / \mathrm{Ca}$ and stable isotope data were not significant, yielding $|\rho|<0.06$ and $p$-values $>0.2$ (Figure 5).

It may be more informative to look at correlations within shorter windows, rather than in the full record, to allow for changes in the initial trace element composition of dripwater through time. For example, around $5400 \mathrm{yr} \mathrm{BP}$, there is a synchronous visible increase in $\delta^{18} \mathrm{O}, \delta^{13} \mathrm{C}$, and $\mathrm{Mg} / \mathrm{Ca}$, but not in $\mathrm{Sr} / \mathrm{Ca}$ (Figure 4, noted with tan bar). Between 5415 and $5366 \mathrm{yr} \mathrm{BP}$, there are significant positive correlations between all three proxies with obvious increases, and not with $\mathrm{Sr} / \mathrm{Ca}$ (Figure $5 \mathrm{~b}$ ). In fact, there is a significant negative correlation between $\delta^{13} \mathrm{C}$ and $\mathrm{Sr} / \mathrm{Ca}$ (Figure 5b). These increased proxy values suggest a multi-decade-long period with drier hydroclimate, which we report with high confidence because of the significant correlations between the proxies. Similar periods of elevated $\mathrm{Mg} / \mathrm{Ca}, \delta^{13} \mathrm{C}$ and $\delta^{18} \mathrm{O}$ occur multiple times throughout the record, including around 5310-5340, 5360, 5570, and 5670 years BP. This association between local maxima in $\mathrm{Mg} / \mathrm{Ca}$ and $\delta^{13} \mathrm{C}$ ratios and periods of high $\delta^{18} \mathrm{O}$ supports the interpretation of $\delta^{18} \mathrm{O}$ as reflecting local moisture availability.

There are several other instances where $\mathrm{Mg} / \mathrm{Ca}$ and $\mathrm{Sr} / \mathrm{Ca}$ increase dramatically, sometimes as much as two-fold. In general, many of the increases in trace element ratio values (shown as troughs in Fig. 4) coincide with elevated stable isotope values (indicating drier conditions), though the $\mathrm{Sr} / \mathrm{Ca}$ response appears to be weaker (Figures 4 and 5). Statistically, $\mathrm{Sr} / \mathrm{Ca}$ and $\mathrm{Mg} / \mathrm{Ca}$ are more similar to $\delta^{13} \mathrm{C}$ than to $\delta^{18} \mathrm{O}$ : trace element ratios and $\delta^{13} \mathrm{C}$ are significantly 
positively correlated in more 50 -year-long windows $(\mathrm{Sr} / \mathrm{Ca}=4 / 9, \mathrm{Mg} / \mathrm{Ca}=7 / 9)$ than trace elements and $\delta^{18} \mathrm{O}(\mathrm{Sr} / \mathrm{Ca}=1 / 9, \mathrm{Mg} / \mathrm{Ca}=3 / 9)$ (Figure 5).

One example of differing $\delta^{18} \mathrm{O}$ behavior occurs around $5550 \mathrm{yr} \mathrm{BP}$, where $\delta^{13} \mathrm{C}, \mathrm{Sr} / \mathrm{Ca}$, and $\mathrm{Mg} / \mathrm{Ca}$ all peak a few years after the most significant increase in $\delta^{18} \mathrm{O}$ (Figure 4, noted with tan bar). These anomalies could be related to threshold behavior in the epikarst, meaning that prior calcite precipitation, water-rock interactions, and degassing, and therefore increases in $\mathrm{Sr} / \mathrm{Ca}$, $\mathrm{Mg} / \mathrm{Ca}$, and $\delta^{13} \mathrm{C}$, happen more slowly than the $\delta^{18} \mathrm{O}_{\text {precip }}$ signal is transmitted to the stalagmite.

\subsubsection{Relationship with drip water trace element compositions}

Because this is the first record of $\mathrm{Mg} / \mathrm{Ca}$ and $\mathrm{Sr} / \mathrm{Ca}$ ratios in a stalagmite from the $\mathrm{YP}$, it is important to compare modern drip water data to our paleo dataset to examine the potential relationship between them and determine the drivers of $\mathrm{Mg} / \mathrm{Ca}$ and $\mathrm{Sr} / \mathrm{Ca}$ in the stalagmite sample.

We used the Day and Henderson (2013) equations for $\mathrm{D}_{\mathrm{Mg}}$ and $\mathrm{D}_{\mathrm{Sr}}$ to calculate expected calcite trace element ratios given modern drip water $[\mathrm{Mg}]$ and $[\mathrm{Sr}]$. Seepage drips had a minimum $\mathrm{Mg} / \mathrm{Ca}$ of $58 \mathrm{mmol} / \mathrm{mol}$ and minimum $\mathrm{Sr} / \mathrm{Ca}$ of $0.33 \mathrm{mmol} / \mathrm{mol}$ ( $\mathrm{n}=2$ drip sites) (Lases-Hernandez, in prep.). Seasonal drips had a minimum $\mathrm{Mg} / \mathrm{Ca}$ of $56 \mathrm{mmol} / \mathrm{mol}$ and minimum $\mathrm{Sr} / \mathrm{Ca}$ of $0.58 \mathrm{mmol} / \mathrm{mol}(\mathrm{n}=1$ drip site) (Lases-Hernandez., in prep.). We then performed a Rayleigh calculation using these drip water trace element ratios as starting concentrations (Johnson et al., 2006). Modeled $\mathrm{Mg} / \mathrm{Ca}$ and $\mathrm{Sr} / \mathrm{Ca}$ values for seepage- and seasonal-type drips overlapped with measured calcite data (Appendix).

Regression of the calcite $\mathrm{Mg} / \mathrm{Ca}$ and $\mathrm{Sr} / \mathrm{Ca}$ data in log space yielded a nearly flat slope $(\mathrm{m}=$ 0.17; Figure 6B). This result suggests that $\mathrm{PCP}$ was not the dominant control on $\mathrm{Mg} / \mathrm{Ca}$ and Sr/Ca during the mid-Holocene (Sinclair et al., 2012). Instead, the regression yields a slope similar to that reported to relate to water-rock interactions $(\mathrm{m}=0.18)$, including calcite recrystallization (Sinclair et al., 2012). Therefore, calcite recrystallization could be the main driver of variability in $\mathrm{Mg} / \mathrm{Ca}$ and $\mathrm{Sr} / \mathrm{Ca}$ ratios (Sinclair et al., 2012).

When considered alongside the stable isotope data that suggest a wetter hydroclimate during the mid-Holocene, the lack of evidence for PCP in trace element ratios from RS1 supports the hypothesis of increased precipitation in comparison to the late Holocene and the modern. We cannot confirm this, however, without trace element ratios from a late Holocene stalagmite. 
Therefore, trace element to calcium ratios may provide an independent tool to assess whether the stable isotope data primarily reflect hydrological changes in RS, but they need to be applied more broadly to be most useful.

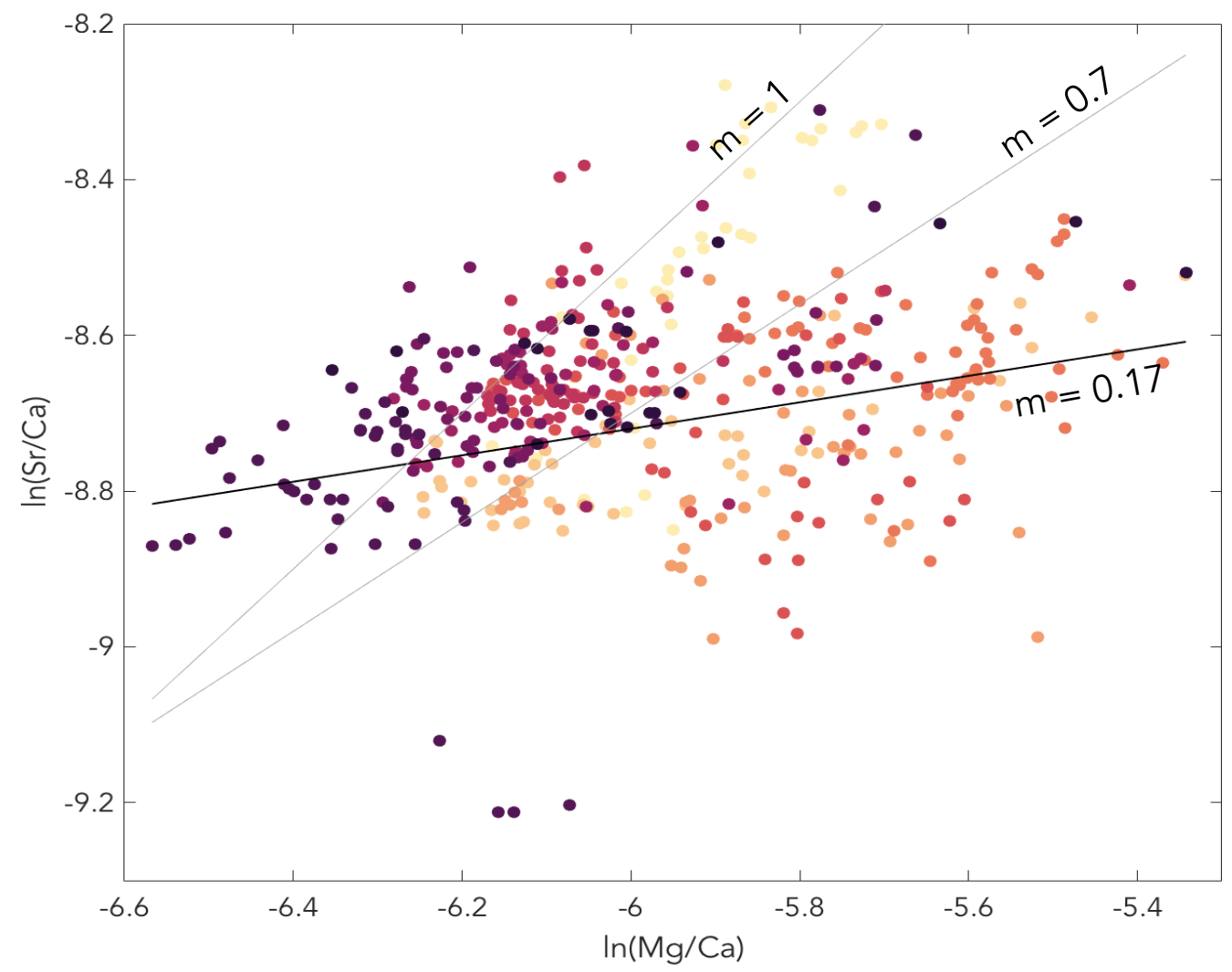

Figure 6. Cross plot of $\mathrm{Sr} / \mathrm{Ca}$ and $\mathrm{Mg} / \mathrm{Ca}$ ratios for RS1. The RS1 data have a nearly flat slope $(m=0.17)$. Higher slopes $(m=0.7-1)$ associated with prior calcite precipitation (Sinclair et al., 2012) are shown for reference, but do not match the RS1 data.

\subsection{Spectral Analysis}

In order to compare mid-Holocene precipitation variability to late Holocene variability, we used spectral analysis to determine periodicity in the four principal components (PCs) from RS1 geochemical proxy data. We assume that all the PCs reflect hydroclimate variability. All four PCs were significantly correlated with the original geochemical records (p-value $<<0.001$; Appendix).

Spectral analysis revealed periods of $\sim 20$ years $^{-1}, \sim 10$ years $^{-1}$, and $\sim 5$ years $^{-1}$ present at the $90 \%$ CI in multiple PCs (Figure 7). At the $80 \% \mathrm{CI}$, an additional period of 50 years $^{-1}$ was noted (Figure 7). 

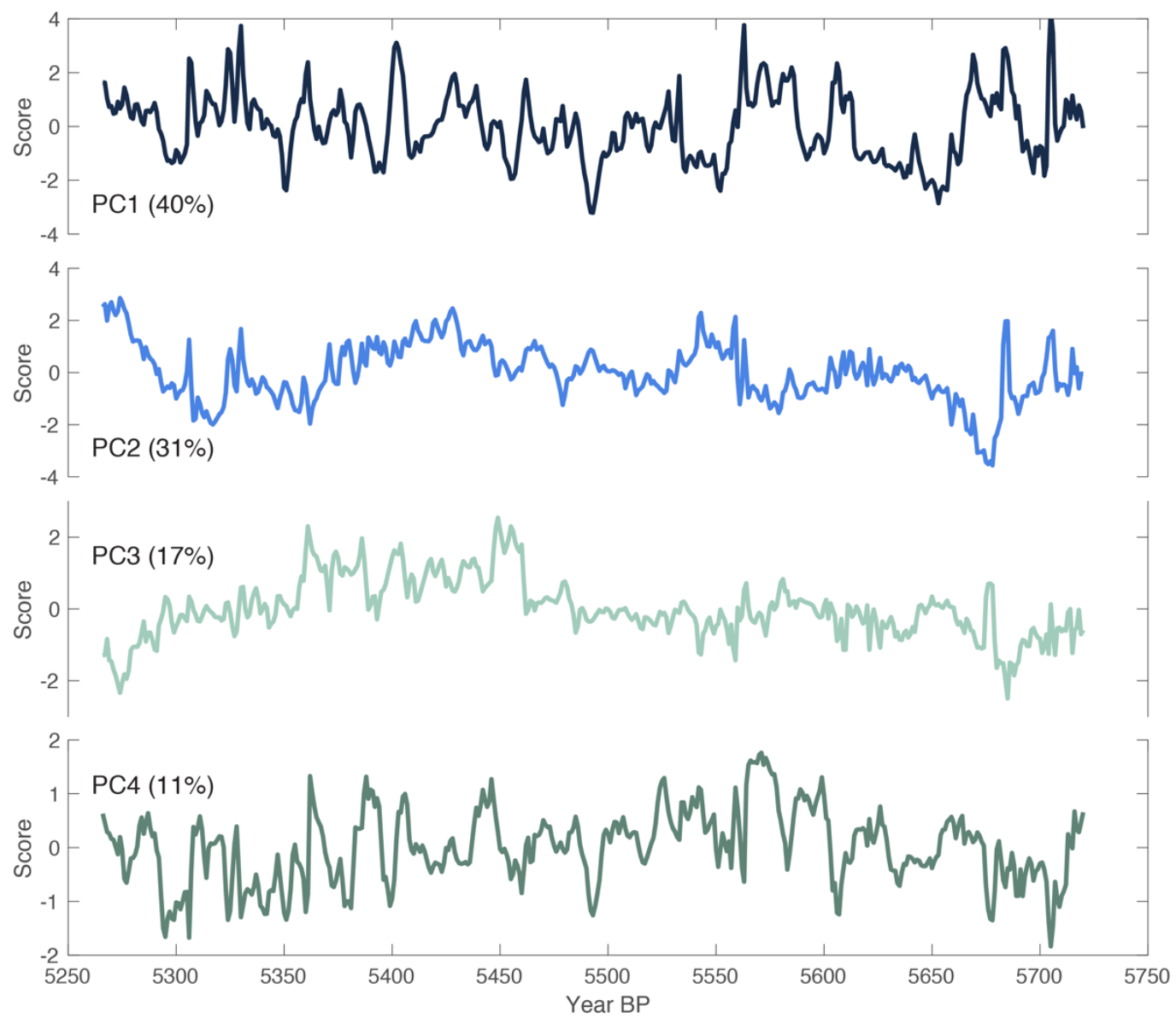

4

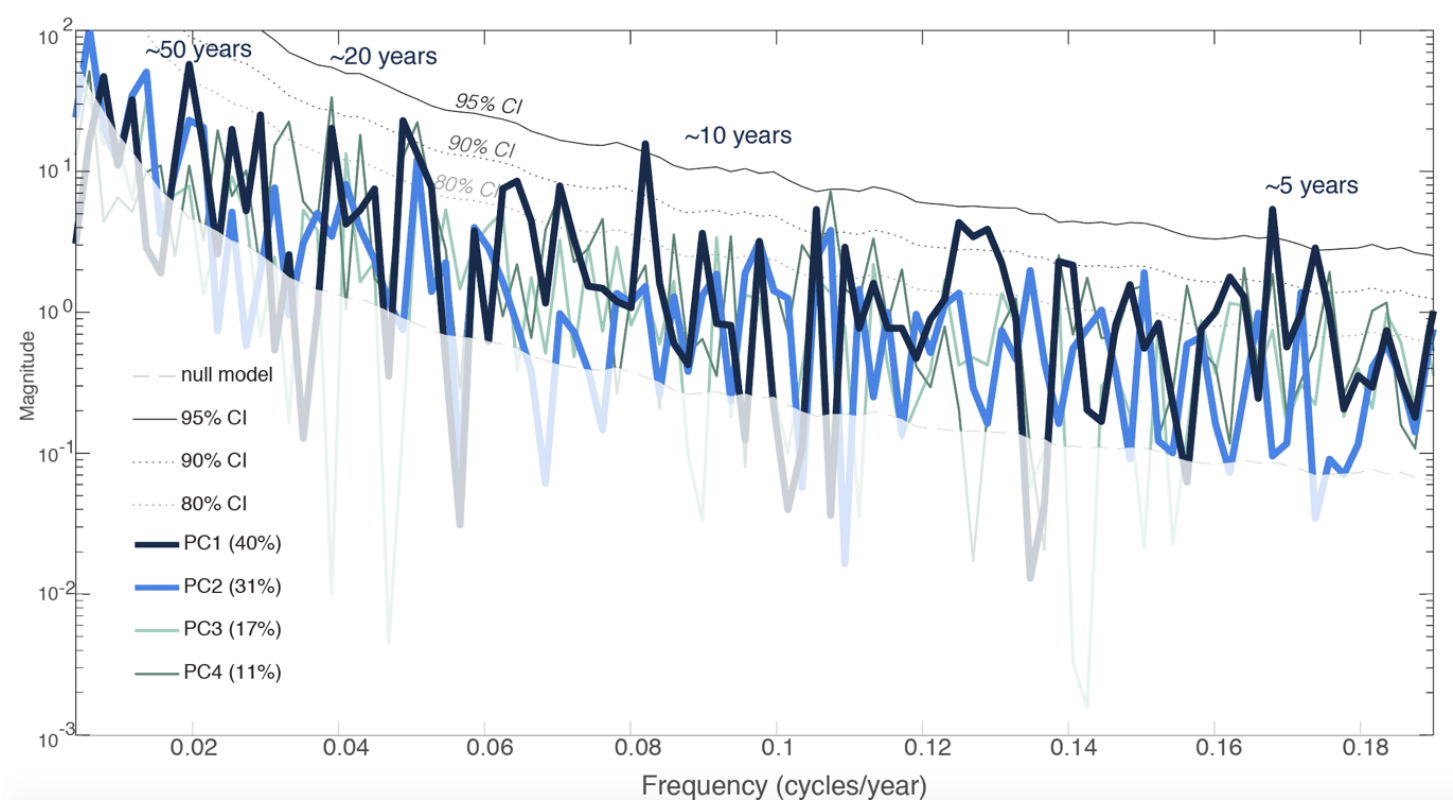

Figure 7. Top. Principal components (PCs) of normalized geochemical data (oxygen isotope, carbon isotope, $\mathrm{Mg} / \mathrm{Ca}$, and $\mathrm{Sr} / \mathrm{Ca}$ ratios) from $\mathrm{RS} 1$. Legend shows variance explained by each PC. Bottom. Spectral analysis of PCs shown in the top panel, with black lines denoting 
confidence intervals from a red noise-based null model. There are cycles with periods of $\sim 20$, 10 , and 5 years present at the $90 \% \mathrm{Cl}$.

\subsection{Comparison to other records}

Although there are several existing paleoclimate records from the YP region (see Section 1 for a summary), in-depth analysis in this study is restricted to Itzamna, a stalagmite from RS that grew during a more recent time period than RS1 ( $3000-1500$ years BP). Because these two stalagmites came from the same cave and have similar dating errors, comparing them allows for a more robust analysis of precipitation variability and amount over time. The Itzamna $\delta^{18} \mathrm{O}$ record has a lower resolution, with an average of 8 years per sample, so we applied an 8-year low-pass Butterworth filter to the higher resolution RS1 $\delta^{18} \mathrm{O}$ record. This filtering method served to remove any variance that would not have been captured in the Itzamna record.
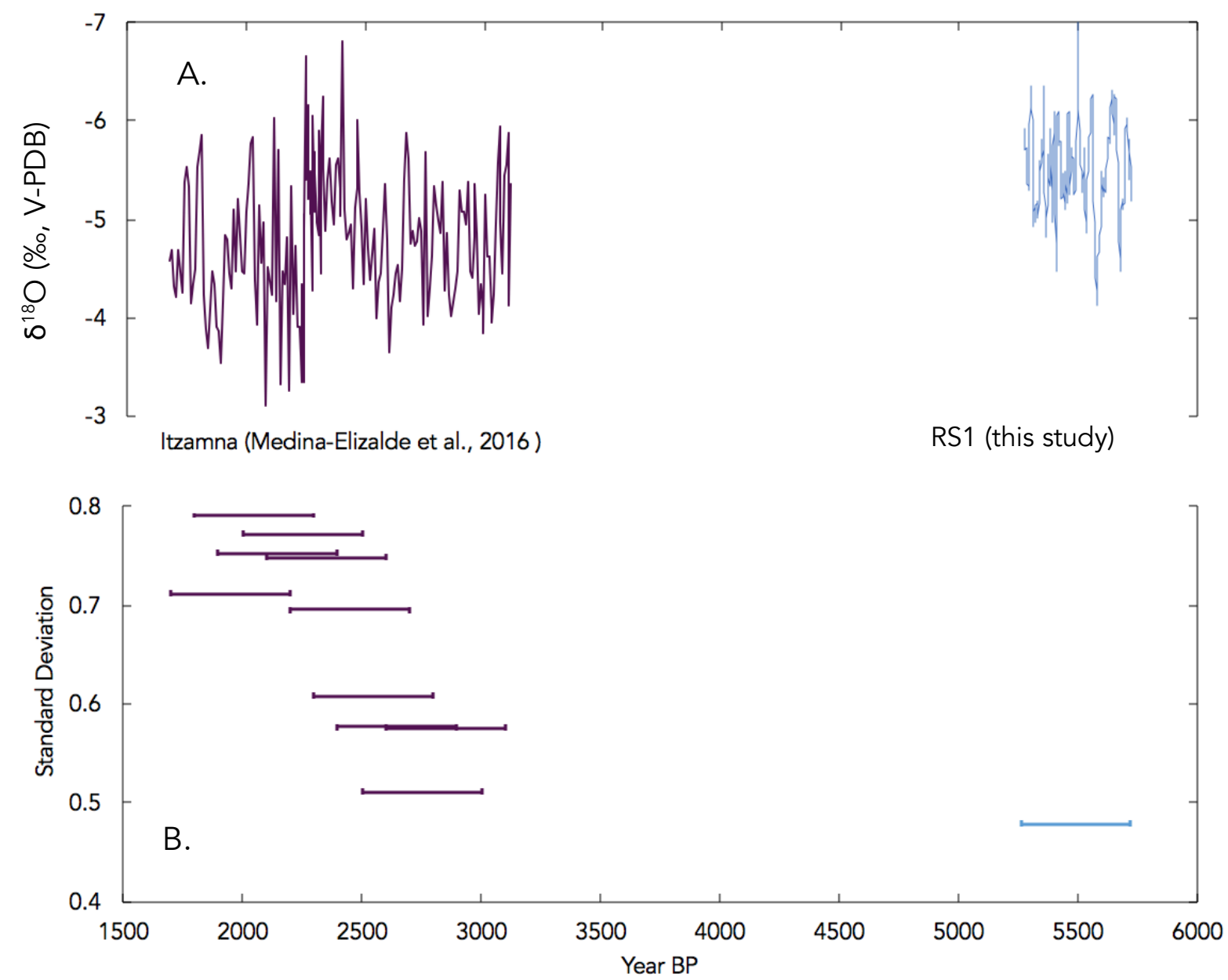

Figure 8. Time series records of $\delta^{18} \mathrm{O}_{\text {calcite }}$ in Itzamna (Medina-Elizalde et al., 2016a) and RS1. B. Standard deviation of 500-year-long snapshots of $\delta^{18} \mathrm{O}_{\text {calite }}$ from Itzamna (Medina-Elizalde et al., 2016a) and RS1 (after applying an 8-year low-pass Butterworth filter), two stalagmites from 
the same cave. Variability and median $\delta^{18} \mathrm{O}$ are both significantly lower in RS1 than in Itzamna (F-test for variance, $\mathrm{p}<<0.001$; Mann-Whitney U-test for median, $\mathrm{p}<<0.001$ ).

The median $\delta^{18} \mathrm{O}_{\text {calcite }}$ for Itzamna was $-4.9 \%$, significantly less negative than RS1's median $\delta^{18} \mathrm{O}_{\text {calcite }}=-5.5 \%$ (Figure 8; Mann-Whitney U-test, $\mathrm{p}<<0.001$ ). The variance in the two stalagmites is also statistically lower in RS1 (F-test, p <<0.001) (Figure 8). The variability in Itzamna increased over time, but was always greater than that of RS1 (Figure 8).

\section{Discussion}

\subsection{Mid-Holocene hydrological variability in the RS1 record}

Based on evidence from previous studies conducted in RS and the observed correlation between oxygen and carbon stable isotope ratios and trace elements, we suggest that $\delta^{18} \mathrm{O}_{\text {calcite }}$ reflects precipitation amount in this region.

There are notable dry periods (more positive ratios, greater than 2SD above mean $\left.\delta^{18} \mathrm{O}_{\text {calcite }}\right)$ around 5675 and $5575 \mathrm{yr} \mathrm{BP}$, which appear to have lasted for 20-50+ years, and two shorter dry intervals around 5400 and $5300 \mathrm{yr}$ BP. The duration of observed dry periods is consistent with spectral analysis showing 20-40-year periods in all PCs, as well as longer cycles (50+ years). We note that some Mesoamerican droughts in both the Common Era and the past century had similar multi-decadal lengths (e.g. Medina-Elizalde et al., 2016a). This similarity shows that multi-decadal precipitation cycles are an integral feature of YP hydroclimate, occurring even during a period of inferred higher mean precipitation and reduced precipitation variance.

Both of the multi-decadal dry periods have a sawtooth pattern in the $\delta^{18} \mathrm{O}_{\text {calcite, }}$ with slow drying and a rapid change back to wetter conditions. Although the $\delta^{18} \mathrm{O}_{\text {calcite }}$ was only outside the $2 \sigma$ envelope briefly (a few years at the inferred maximum of the dry period), the slow drying lasted for decades. The trace element to calcium ratios and $\delta^{13} \mathrm{C}_{\text {calcite }}$ don't follow the same sawtooth shape; instead, they have a few sharp increases during the dry periods.

Taken together, the qualitative agreement and the statistical correlations between trace elements and stable isotopes show that it is feasible to use $\mathrm{Mg} / \mathrm{Ca}$ and $\mathrm{Sr} / \mathrm{Ca}$ as paleoclimate proxies in this region. Furthermore, we suggest that it is prudent to collect data on all four 
proxies because they record hydrological variability in different ways, potentially enriching the interpretation of the record.

Further statistical analysis would help to strengthen the interpretations of these periods and improve the rigor or robustness of these results, as the $90 \%$ confidence interval is a low bar for significance. These analyses could include any combination of the following: wavelet transformations to see how periodicity changed over time, Butterworth filtering to reduce high frequency noise or remove long-term trends, or EOF analysis to check periodicity against other records. Butterworth filtering could also help clarify interpretations of the drivers behind each principal component identified in the record.

\subsection{Comparison to other records}

Analysis of RS1 compared to Itzamna showed decreased variability and increased mean $\delta^{18} \mathrm{O}$ in the mid-Holocene (compared to the late Holocene). Because both samples come from the same cave, we assume that the differences in the variability of both $\delta^{18} \mathrm{O}$ records are only due to changes in hydroclimate over time and not due to temperature variance or inter-cave differences, as might be the case when using stalagmites from two different caves for temporal comparisons.

Therefore, we conclude that the YP was experiencing significantly different climate patterns between the late Holocene and the mid-Holocene. Lower average $\delta^{18} \mathrm{O}_{\text {calcite }}$ during the mid-Holocene (RS1 growth period) suggests that there was more precipitation than during the late Holocene. Trace element ratios with a lack of evidence for PCP also support the hypothesized wetter mid-Holocene, as the aquifer may have been too wet for PCP to occur in the epikarst.

These observations are consistent with results from previous stalagmite studies in Belize that found wetter, less variable mid-Holocene hydroclimate (e.g. Metcalfe et al., 2009; Pollock et al., 2016) in comparison to the later Holocene. Lacustrine records from the YP also showed higher mid-Holocene lake levels (Hodell et al., 1995; Whitmore et al., 1996), and a series of calcite rafts from other caves in the YP show progressive drying from 7,000 years BP to the present (Kovacs et al., 2017). Regional agreement among these paleoclimate records, across proxies and archives, suggests that the driver of increased precipitation amount and decreased precipitation variability is not isolated to this cave site or restricted to this short interval of the 
mid-Holocene. Instead, the driver(s) is at least regional in scale, and persisted for several thousand years.

Increased precipitation amount is likely due (in part) to increased seasonality during the mid-Holocene, which preferentially warmed North Atlantic summer SSTs, promoting increased YP precipitation via enhanced moisture transport by the CLLJ and a more northerly mean position of the ITCZ. This pattern has been observed in the instrumental record and model simulations (Bhattacharya et al., 2017), and has been invoked to explain other observed proxy records (Ridley et al., 2015; Pollock et al., 2016).

Increased tropical cyclone activity could also have played a part in increasing YP precipitation in the mid-Holocene. Pausata et al. (2017) modeled tropical cyclone activity at 6 kyr BP and demonstrated that increased seasonality, a vegetated Sahara, and a reduction in Saharan dust emissions could lead to an increase in tropical cyclones during the mid-Holocene, especially in the Caribbean. Though we cannot resolve individual high-precipitation events in our record, our results are consistent with increased frequency of tropical cyclones from 5.7 to 5.2 kyr BP, compared to the late Holocene and pre-industrial periods.

Lower precipitation variability during the mid-Holocene could be related to reduced ENSO variability. Several studies have shown that the mid-Holocene was a period of reduced ENSO variance compared to the late Holocene (Carré et al., 2014; Chen et al., 2016; Emile-Geay et al., 2016; Koutavas et al., 2006; Koutavas and Joanides, 2012). Summer CLLJ variability is thought to be linked to tropical Pacific variability (Muñoz et al., 2008), so decreased Pacific SST variability could lead to a more stable CLLJ, yielding the diminished precipitation variation we observe in RS1.

Previous modeling, monitoring, and proxy data have suggested that ENSO mean state influences tropical Atlantic cyclone formation (Elsner et al., 1999; Frappier et al., 2014; LasesHernandez et al., 2019; Medina-Elizalde et al., 2016b; Wu \& Lau, 1992). Therefore, decreased ENSO variability during the mid-Holocene could reduce changes in the frequency of tropical cyclones, further decreasing the amplitude of precipitation variability in the YP.

Our study contributes to a wide range of work linking Atlantic Multidecadal Variability (AMV; formerly known as Atlantic Multidecadal Oscillation or AMO) to Caribbean and Gulf of Mexico hydroclimate (Alexander et al., 2014; Bhattacharya et al., 2017; Karmalkar et al., 2011; Knight et al., 2006). Instrumental, paleoclimate, and modeling data also support a link between 
AMV and hydroclimate over multiple other regions, including the North Atlantic (Knight et al., 2006), northeastern Brazil (Sutton et al., 2005), African Sahel (Folland et al., 1986; Rowell et al., 1992), western Europe (Folland et al., 1986; Knight et al., 2006; Sutton et al., 2005), and North America (Fensterer et al., 2012; Folland et al., 2001; Medina-Elizalde et al., 2017). Future work should examine whether paleoclimate records with decadal-scale resolution from these other regions also show reduced variance in the mid-Holocene relative to the late Holocene.

Regardless of the climate dynamics at play, the 20-50-year cyclicity and rapid drying observed in RS1 indicate significant multidecadal wet-dry cycles, much like there are in the present and late Holocene YP, despite the wetter, warmer climate state. Thus, we expect similar, multidecadal droughts both under future climate warming and in other paleoclimate records from this region, including others that overlap with shifts in ancient Maya society.

\section{Conclusions}

In this study, we have presented a precisely dated, high-resolution, multiproxy YP paleoclimate record spanning a 455-year-long interval (5720 - $5266 \mathrm{yr}$ BP) of the mid-Holocene. The record is consistent with previous observations of increased precipitation in the midHolocene compared to the late Holocene. Results from this study suggest that multi-decadal precipitation variations were a persistent feature in regional hydroclimate during the midHolocene, just as they were in the past 2 millennia, but with reduced amplitude. Because the mid-Holocene had a different climate mean state (more summer solar input and higher mean precipitation) than the late Holocene, we conclude that background climate can impact precipitation variability in the YP. We suggest that mid-Holocene reductions in ENSO and/or AMV variability, driven by altered seasonality, led to more stable YP precipitation patterns. As background climate changes under anthropogenic warming conditions, it will be important to model predicted changes in precipitation mean and variance. Models of future hydroclimate can be tested by comparing predicted variance at $6 \mathrm{kyr} \mathrm{BP}$ to that recorded in other proxy records and $6 \mathrm{kyr}$ models.

Although stalagmites provide only a short snapshot of hydroclimate during their growth period, this study demonstrates the utility of single-cave, multi-stalagmite analyses, especially when considering changes in variability over time. This work presents the first record of stalagmite $\mathrm{Mg} / \mathrm{Ca}$ and $\mathrm{Sr} / \mathrm{Ca}$ ratios in the Yucatán Peninsula. Our results support the inclusion of 
trace element ratios in stalagmites that cover changes in ancient Maya civilization to provide additional climate information. These results are a step forward in YP paleo proxy interpretations and provide a better understanding of controls on precipitation amount and variability.

\section{Acknowledgements}

Data generated in this study are available in the appendix. Other data from Rio Secreto, including data from Itzamna and drip waters, are available as supplementary data in MedinaElizalde et al. (2016a) and Lases-Hernandez et al. (2020). Trace element data from Río Secreto drip water will be available upon publication of Lases-Hernandez et al. (in prep.), a doctoral thesis.

This work was funded by US National Science Foundation grants AGS-1702848 (M. MedinaElizalde) and AGS-1502877 (S. Burns). Additional support was provided by the MIT EAPS Student Research Fund and the WHOI Ocean Ventures Fund. We appreciate Nick Scroxton's work on XRD analysis and statistical insights, and Sarah Weidman's contribution to drilling at MIT. Finally, we thank the staff at Río Secreto Cave for their assistance.

Upon final publication in a peer-reviewed journal, the full author list of this manuscript will be: Serrato Marks, Gabriela, Medina-Elizalde, Martín, Burns, Stephen, Weldeab, Syee, LasesHernandez, Fernanda, Cazares, Gabriela, McGee, David.

\section{References}

Akers, P. D., Brook, G. A., Railsback, L.B., Liang, F., Iannon, G., Webster, J.W., et al. (2016). An extended and higher-resolution record of climate and land use from stalagmite MC01 from Macal Chasm, Belize, revealing connections between major dry events, overall climate variability, and Maya sociopolitical changes. Palaeogeography, Palaeoclimatology, Palaeoecology, 459, 268-288. https://doi.org/10.1016/j.palaeo.2016.07.007

Bhattacharya, T., Chiang, J., \& Cheng, W. (2017) Ocean-atmosphere dynamics linked to 8001050 CE drying in Mesoamerica. Quaternary Science Reviews 169, $263-277$. https://doi.org/10.1016/j.quascirev.2017.06.005

Breitenbach, S. F. M, Rehfeld, K., Goswami, B., Baldini, J. U. L., Ridley, H.E., Kennett, D. J., et al. (2012). Constructing proxy records from age models (COPRA). Climate of the Past $\mathbf{8}$, 1765-1779. https://doi.org/10.5194/cp-8-1765-2012

Burns, S. J., Matter, A., Frank, N., \& Mangini, A. (1998). Speleothem-based paleoclimate record from northern Oman. Geology, 26(6), 499-502. https://doi.org/10.1130/00917613(1998)026\%3C0499:SBPRFN\%3E2.3.CO;2

Burns, S. J., Godfrey, L. R., Faina, P., McGee, D., Hardt, B., Ranivoharimanana, L., \& Randrianasy, J. (2016). Rapid human-induced landscape transformation in Madagascar at the end of the first millennium of the Common Era. Quaternary Science Reviews, 134, 9299. https://doi.org/10.1016/j.quascirev.2016.01.007

Bush, M. B., Correa-Metrio, A. Y., Hodell, D. A., Brenner, M., Anselmetti, F. S., Ariztegui, D., et al. (2009). Re-evaluation of Climate Change in Lowland Central America During the Last 
Glacial Maximum Using New Sediment Cores from Lake Petén Itzá, Guatemala (pp. 113128). https://doi.org/10.1007/978-90-481-2672-9 5

Carré, M., Sachs, J. P., Purca, S., Schauer, A. J., Braconnot, P., Falcón, R. A., et al. (2014). Holocene history of ENSO variance and asymmetry in the eastern tropical Pacific. Science, 345(6200), 1045-1048. https://doi.org/10.1126/science.1252220

Chen, S., Hoffmann, S. S., Lund, D. C., Cobb, K. M., Emile-Geay, J., \& Adkins, J. F. (2016). A high-resolution speleothem record of western equatorial Pacific rainfall: Implications for Holocene ENSO evolution. Earth and Planetary Science Letters, 442, 61-71. https://doi.org/10.1016/j.eps1.2016.02.050

Cruz, F. Burns, S. J., Jercinovic, M., Karmann, I., Sharp, W. D., \& Vuille, M. (2017) Evidence of rainfall variations in Southern Brazil from trace element ratios $(\mathrm{Mg} / \mathrm{Ca}$ and $\mathrm{Sr} / \mathrm{Ca})$ in a Late Pleistocene stalagmite. Geochimica et Cosmochimica Acta 71, 2250-2263. https://doi.org/10.1016/j.gca.2007.02.005

Dansgaard, W. (1964) Stable isotopes in precipitation. Tellus, 16, 436-468. https://doi.org/10.1111/j.2153-3490.1964.tb00181.x

Day, C. C, \& Henderson, G. M. (2013) Controls on trace-element partitioning in cave-analogue calcite. Geochimica et Cosmochimica Acta, 120, 612-627. https://doi.org/10.1016/j.gca.2013.05.044

Dee, S. G., Parsons, L. A., Loope, G. R., Overpeck, J. T., Ault, T. R., \& Emile-Geay, J. (2017). Improved spectral comparisons of paleoclimate models and observations via proxy system modeling: Implications for multi-decadal variability. Earth and Planetary Science Letters, 476, 34-46. https://doi.org/10.1016/j.eps1.2017.07.036

Douglas, P. M. J., Pagani, M., Canuto, M. A., Brenner, M., Hodell, D. A., Eglinton, T. I., \& Curtis, J. H. (2015). Drought, agricultural adaptation, and sociopolitical collapse in the Maya Lowlands. Proceedings of the National Academy of Sciences of the United States of America. https://doi.org/10.1073/pnas.1419133112

Elsner, J. B., Kara, A. B., \& Owens, M. A. (1999). Fluctuations in North Atlantic hurricane frequency. Journal of Climate, 12(2), 427-437. https://doi.org/10.1175/15200442(1999)012<0427:FINAHF $>2.0$. CO;2

Emile-Geay, J., Cobb, K. M., Carré, M. Braconnot, P., Leloup, K., Zhou, Y., et al. (2016). Links between tropical Pacific seasonal, interannual and orbital variability during the Holocene. Nature Geoscience, 9, 168-173. https://doi.org/10.1038/ngeo2608

Fairchild, I.J., Borsato, A., Tooth, A.F., Frisia, S., Hawkesworth, C. J., Huang, Y., et al. (2000). Controls on trace element (Sr-Mg) compositions of carbonate cave waters: implications for speleothem climatic records. Chemical Geology, 166(3-4), 255-269. https://doi.org/10.1016/S0009-2541(99)00216-8

Fairchild, I.J., Baker, A., Borsato, A., Frisia, S., Hinton, R.W., McDermott, F., \& Tooth, A.F. (2001). Annual to sub-annual resolution of multiple trace-element trends in speleothems. Journal of the Geological Society, 158(5), 831-841. https://doi.org/10.1144/jgs.158.5.831

Fensterer, C., Scholz, D., Hoffmann, D., Spötl, C., Pajón, J. M., \& Mangini, A. (2012). Cuban stalagmite suggests relationship between Caribbean precipitation and the Atlantic Multidecadal Oscillation during the past $1.3 \mathrm{ka}$. Holocene, 22(12), 1405-1412. https://doi.org/10.1177/0959683612449759

Folland, C. K., Palmer, T. N., \& Parker, D. E. (1986). Sahel rainfall and worldwide sea temperatures, 1901-85. Nature. https://doi.org/10.1038/320602a0 
Folland, C. K., Colman, A. W., Rowell, D. P., \& Davey, M. K. (2001). Predictability of northeast Brazil rainfall and real-time forecast skill, 1987-98. Journal of Climate. https://doi.org/10.1175/1520-0442(2001)014<1937:PONBRA $>2.0 . C O ; 2$

Frappier, A. B., Sahagian, D., Carpenter, S. J., González, L. A., \& Frappier, B. R. (2007). Stalagmite stable isotope record of recent tropic cyclone events. Geology, 35(2), 111-114. https://doi.org/10.1130/G23145A.1

Frappier, A., Pyburn, J., Pinkey-Drobnis, A.D., Wang, X., Corbett, D.R., \& Dahlin, B.H. (2014). Two millennia of tropical cyclone-induced mud layers in a northern Yucatán stalagmite: Multiple overlapping climatic hazards during the Maya Terminal Classic "megadroughts." Geophysical Research Letters, 41(14), 5148-5157. https://doi.org/10.1002/2014GL059882

Genty, D., Baker, A., Massault, M., Proctor, C., Gilmour, M., Pons-Branchu, E., \& Hamelin, B. (2001). Dead carbon in stalagmites: Carbonate bedrock paleodissolution vs. ageing of soil organic matter. Implications for 13C variations in speleothems, Geochimica et Cosmochimica Acta, 65(20), 3443-3457. https://doi.org/10.1016/S0016-7037(01)00697-4

Genty, D., Blamart, D., Ghaleb, B., Plagnes, V., Causse, C., Bakalowicz, M., et al. (2006). Timing and dynamics of the last deglaciation from European and North African $\delta 13 \mathrm{C}$ stalagmite profiles - comparison with Chinese and South Hemisphere stalagmites. Quaternary Science Reviews, 25(17-18), 2118-2142. https://doi.org/10.1016/j.quascirev.2006.01.030

Giannini, A., Kishnir, Y., \& Cane, M. A. (2000). Interannual Variability of Caribbean Rainfall, ENSO, and the Atlantic Ocean. Journal of Climate, 32(18), 297-311. https://doi.org/10.1175/1520-0442(2000)013\%3C0297:IVOCRE\%3E2.0.CO;2

Hellstrom, J., McCulloch, M., \& Stone, J. (1998). A detailed 31,000-year record of climate and vegetation change from the isotope geochemistry of two New Zealand speleothems. Quaternary Research, 50, 167-178. https://doi.org/10.1006/qres.1998.1991

Hodell, D. A., Curtis, J. H., \& Brenner, M. (1995). Possible role of climate in the collapse of Classic Maya civilization. Nature, 375(6530), 391-394. https://doi.org/10.1038/375391a0

Hodell, D. A., Brenner, M., \& Curtis, J. H. (2005). Climate change on the Yucatan Peninsula during the little ice age. Quaternary Research, 63, 109-121. https://doi.org/10.1016/j.yqres.2004.11.004

Johnson, K. R., Hu, C., Belshaw., N. S., et al. (2006). Seasonal trace-element and stable-isotope variations in a Chinese speleothem: The potential for high-resolution paleo monsoon reconstruction. Earth and Planetary Science Letters, 244(1-2), 394-407. https://doi.org/10.1016/j.epsl.2006.01.064

Karmalkar, A. V., Bradley, R. S., \& Diaz, H. F. (2011). Climate change in Central America and Mexico: regional climate model validation and climate change projections. Climate Dynamics, 37, 605-629. https://doi.org/10.1007/s00382-011-1099-9

Knight, J. R., Folland, C. K., \& Scaife, A. A. (2006). Climate impacts of the Atlantic multidecadal oscillation. Geophysical Research Letters, 33(17). https://doi.org/10.1029/2006GL026242

Koutavas, A., deMenocal., P.B., Olive, G.C., \& Lynch-Stieglitz, J. (2006). Mid-Holocene El Niño-Southern Oscillation (ENSO) attenuation revealed by individual foraminifera in eastern tropical Pacific sediments. Geology, 34(12), 993-996. https://doi.org/10.1130/G22810A.1 
Koutavas, A., Joanides, S. (2012). El Niño-Southern Oscillation extrema in the Holocene and Last Glacial Maximum. Paleoceanography and Paleoclimatology, 27(4), PA4208. https://doi.org/10.1029/2012PA002378

Lachniet, M. S., Burns, S. J., Piperno, D. R., Asmerom, Y., Polyak, V., Moy, C. M., \& Christenson, K. (2004). A 1500-year El Niño/Southern Oscillation and rainfall history for the isthmus of Panama from speleothem calcite. Journal of Geophysical Research Atmospheres, 109(D20). https://doi.org/10.1029/2004JD004694

Lachniet, M. S., Asmerom, Y., Polyak, V., \& Bernal, J. P. (2017). Two millennia of Mesoamerican monsoon variability driven by Pacific and Atlantic synergistic forcing. Quaternary Science Reviews, 155, 100-113. https://doi.org/10.1016/j.quascirev.2016.11.012

Lases-Hernandez, F., Medina-Elizalde, M., Burns, S., \& DeCesare, M. (2019). Long-term monitoring of drip water and groundwater stable isotopic variability in the Yucatán Peninsula: Implications for recharge and speleothem rainfall reconstruction. Geochimica et Cosmochimica Acta, 246, 41-59. https://doi.org/10.1016/j.gca.2018.11.028

Lases-Hernandez, F., Medina-Elizalde, M., Frappier, A. B. (2020). Drip water $\delta 180$ variability in the northeastern Yucatán Peninsula, Mexico: Implications for tropical cyclone detection and rainfall reconstruction from speleothems. Geochimica et Cosmochimica Acta 285, 237256. https://doi.org/10.1016/j.gca.2020.07.008

Lases-Hernandez, F., in prep. Characterization of geochemical and environmental processes that modulate the isotopic and elemental composition of drip water and calcite in Rio Secreto, a karstic system in the Yucatan Peninsula, Mexico. Doctoral Thesis.

Laskar, J., Robutel, P., Gastineau, M., Correia, C. M., \& Levrard, B. (2004). A long-term numerical solution for the insolation quantities of the Earth. Astronomy and Astrophysics, 428(1), 261-285. https://doi.org/10.1051/0004-6361:20041335

Lechleitner, F. A., Breitenbach, S. F. M., Rehfeld, K., Ridley, H. E., Asmerom, Y., Prufer, K. M. et al. (2017). Tropical rainfall over the last two millennia: evidence for a low-latitude hydrologic seesaw. Scientific Reports, 7(1), 45809. https://doi.org/10.1038/srep45809

Lewis, S. C., Gagan, M. K., Ayliffe, L. K., Zhao, J. X., Hantoro, W. S., Treble, P. C., \& Suwargadi, B. W. (2011). High-resolution stalagmite reconstructions of AustralianIndonesian monsoon rainfall variability during Heinrich stadial 3 and Greenland interstadial 4. Earth and Planetary Science Letters, 303(1-2), 133-142. https://doi.org/10.1016/j.eps1.2010.12.048

McCabe, G. J., Palecki, M. A., \& Betancourt, J. L. (2004). Pacific and Atlantic Ocean influences on multidecadal drought frequency in the United States. Proceedings of the National Academy of Sciences of the United States of America, 101(12), 4136-4141. https://doi.org/10.1073/pnas.0306738101

McGee, D., Donohoe, A., Marshall, J., \& Ferreira, D. (2014). Changes in ITCZ location and cross-equatorial heat transport at the Last Glacial Maximum, Heinrich Stadial 1, and the mid-Holocene. Earth and Planetary Science Letters, 390, 69-79. https://doi.org/10.1016/j.epsl.2013.12.043

Medina-Elizalde, M., Burns, S., Lea, D., Asmerom, Y., von Gunten, L., \& Polyak, V. (2010). High resolution stalagmite climate record from the Yucatán Peninsula spanning the Maya terminal classic period. Earth and Planetary Science Letters, 298(1-2), 255-262. https://doi.org/10.1016/j.eps1.2010.08.016

Medina-Elizalde, M., Burns, S. J., Polanco-Martinez, J. M., Beach, T., Lases-Hernandez, F., \& Shen, C. C. (2016a). High-resolution speleothem record of precipitation from the Yucatan 
Peninsula spanning the Maya Preclassic Period. Global and Planetary Change 138, 93-102. https://doi.org/10.1016/j.gloplacha.2015.10.003

Medina-Elizalde, M., Polanco-Martínez, J. M., Lases-Hernández, F., Bradley, R., \& Burns, S. (2016b). Testing the "tropical storm" hypothesis of Yucatan Peninsula climate variability during the Maya Terminal Classic Period. Quaternary Research 86, 111-119. https://doi.org/10.1016/j.yqres.2016.05.006

Medina-Elizalde, M., Burns, S.J., Polanco-Martinez, J.M., Lases-Hernández, F., Bradley, R., Wang H. et al. (2017). Synchronous precipitation reduction in the American Tropics associated with Heinrich 2. Scientific Reports 7, 11216. https://doi.org/10.1038/s41598-017$\underline{11742-8}$

Mestas-Nuñez, A. M., Enfield, D. B., \& Zhang, C. (2007). Water vapor fluxes over the IntraAmericas Sea: Seasonal and interannual variability and associations with rainfall. Journal of Climate, 20(9), 1910-1922. https://doi.org/10.1175/JCLI4096.1

Metcalfe, S., Breen, A., Murray, M., Furley, P., Fallick, A., \& McKenzie, A. (2009). Environmental change in northern Belize since the latest Pleistocene. Journal of Quaternary Science 24, 627-641. https://doi.org/10.1002/jqs.1248

Muñoz, E., Busalacchi, A. J., Nigam, S., \& Ruiz-Barradas, A. (2008). Winter and summer structure of the Caribbean low-level jet. Journal of Climate, 21(6), 1260-1276. https://doi.org/10.1175/2007JCLI1855.1

Pausata, F. S. R., Emanuel, K. A., Chiacchio, M., Diro, G. T., Zhang, Q., Sushama, L., et al. (2017). Tropical cyclone activity enhanced by Sahara greening and reduced dust emissions during the African Humid Period. Proceedings of the National Academy of Sciences of the United States of America, 114(24), 6221-6226. https://doi.org/10.1073/pnas.1619111114

Pollock, A. L., van Beynen, P. E., DeLong, K. L., Asmerom, Y., \& Reeder, P. P. (2016). A midHolocene paleoprecipitation record from Belize. Palaeogeography Palaeoclimatology

Palaeoecology 463, 103-111. https://doi.org/10.1016/j.palaeo.2016.09.021

Roberts, M. S., Smart, P. L., \& Baker, A. (1998). Annual trace element variations in a Holocene speleothem. Earth and Planetary Science Letters 154(1-4), 237-246 https://doi.org/10.1016/S0012-821X(97)00116-7

Rosenmeier, M. F., Hodell, D. A., Brenner, M., Curtis, J. H., \& Guilderson, T. P. (2002). A 4000-year lacustrine record of environmental change in the southern Maya lowlands, Petén, Guatemala. Quaternary Research, 57(2), 183-190. https://doi.org/10.1006/qres.2001.2305

Rowell, D. P., Folland, C. K., Maskell, K., Owen, J. A., \& Ward, M. N. (1992). Modelling the influence of global sea surface temperatures on the variability and predictability of seasonal Sahel rainfall. Geophysical Research Letters, 19(9), 905-908. https://doi.org/10.1029/92GL00939

Roy, P., Torrescano-Valle, N., Islebe, G., \& Gutiérrez-Ayala, L. V. (2017). Late Holocene hydroclimate of the western Yucatan Peninsula (Mexico). Journal of Quaternary Science 32(8), 1112-1120. https://doi.org/10.1002/jqs.2988

Sinclair, D. J., Banner, J. L., Taylor, F. W., Partin, J., Jenson, J., Mylroie, J. et al. (2012). Magnesium and strontium systematics in tropical speleothems from the Western Pacific. Chemical Geology 294-295, 1-17. https://doi.org/10.1016/j.chemgeo.2011.10.008

Stahle, D. W., Burnette, D. J., \& Diaz, J.V. (2012). Pacific and Atlantic influences on Mesoamerican climate over the past millennium. Climate Dynamics 39(6), 1431-1446. https://doi.org/10.1007/s00382-011-1205-z 
Sutton, R. T., \& Hodson, D. L. R. (2005). Ocean science: Atlantic Ocean forcing of North American and European summer climate. Science, 309(5731), 115-118. https://doi.org/10.1126/science.1109496

Tremaine, D. M., Froelich, P. N., \& Wang, Y. (2011). Speleothem calcite farmed in situ: Modern calibration of $\delta^{18} \mathrm{O}$ and $\delta^{13} \mathrm{C}$ paleoclimate proxies in a continuously-monitored natural cave system. Geochimica et Cosmochimica Acta 75(17), 4929-4950. https://doi.org/10.1016/j.gca.2011.06.005

Tremaine, D. M., \& Froelich, P. N. (2013). Speleothem trace element signatures: A hydrologic geochemical study of modern cave dripwaters and farmed calcite. Geochimica et Cosmochimica Acta 121, 522-545. https://doi.org/10.1016/j.gca.2013.07.026

Vuille, M., Bradley, R. S., Healy, R., Werner, M., Hardy, D. R., Thompson, L. G., \& Keimig, F. (2003). Modeling $\delta 180$ in precipitation over the tropical Americas: 2. Simulation of the stable isotope signal in Andean ice cores. Journal of Geophysical Research D: Atmospheres, 108(6). https://doi.org/10.1029/2001jd002039

Whitmore, T. J., Brenner, M., Curtis, J. H., Dahlin, B. H., \& Leyden, B. W. (1996). Holocene climatic and human influences on lakes of the Yucatan Peninsula, Mexico: An interdisciplinary, palaeolimnological approach. Holocene, 6(3), 273-287. https://doi.org/10.1177/095968369600600303

Willmott, C. J., \& K. Matsuura (2001). Terrestrial Air Temperature and Precipitation: Monthly and Annual Time Series (1950 - 1999), http://climate.geog.udel.edu/ climate/html pages/README.ghen ts2.html

Wong, C. I., \& Breecker, D. O. (2015). Advancements in the use of speleothems as climate archives. Quaternary Science Reviews 127, 1-18. https://doi.org/10.1016/j.quascirev.2015.07.019

Guoxiong Wu, \& Ngar-Cheung Lau. (1992). A GCM simulation of the relationship between tropical-storm formation and ENSO. Monthly Weather Review, 120(6), 958-977. https://doi.org/10.1175/1520-0493(1993)121<2137:cogsot $>2.0 . \operatorname{co} ; 2$ 


\section{Appendix A. Figures and Supplementary Information}

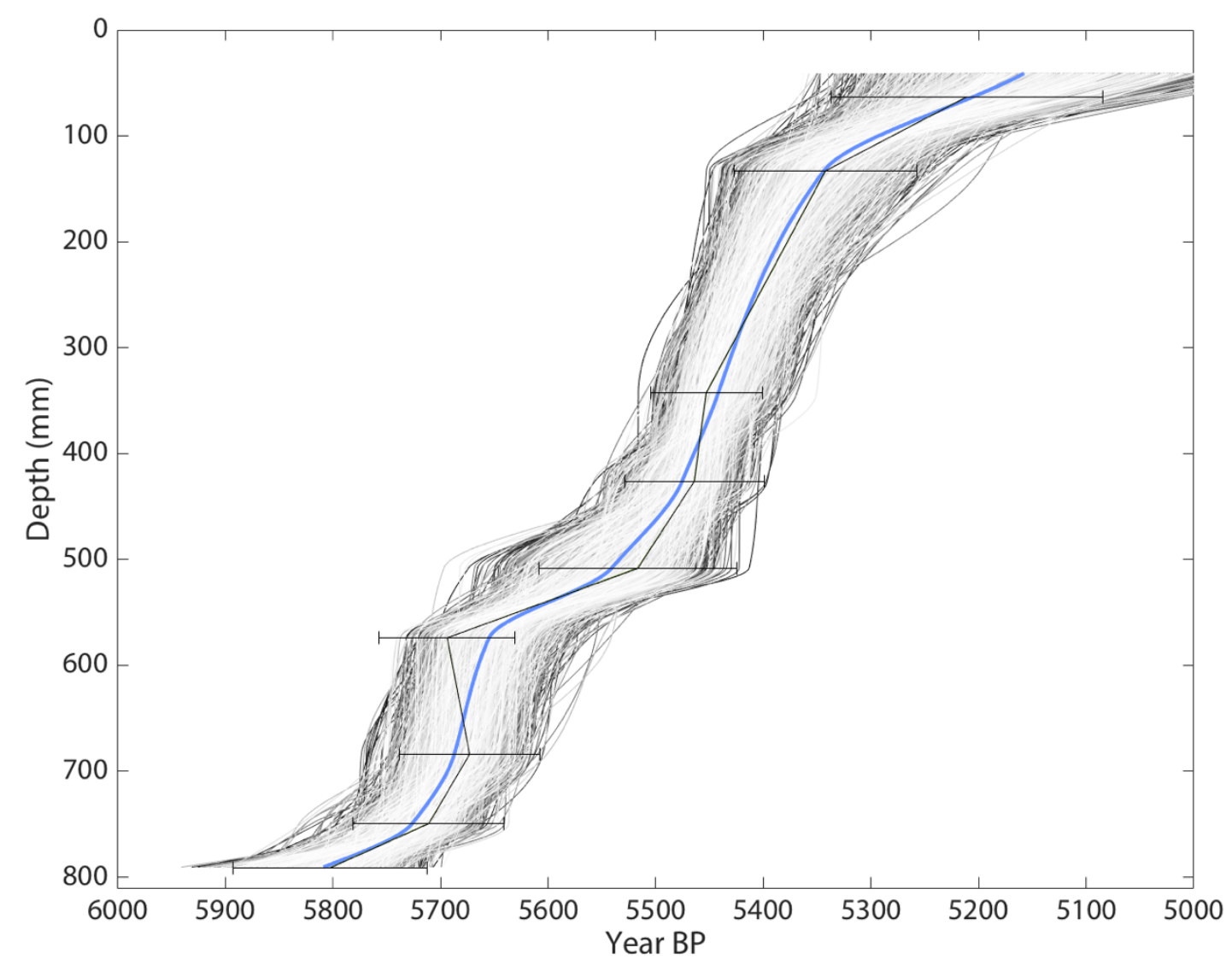

Figure A1. Age-depth model for RS1 based on U/Th dates with 2000 Monte Carlo simulations, without layer counting.

In addition to the layer counting and thickness measurements, XRD analysis was performed at UMass Amherst to identify the mineralogy of visually distinct segments. Samples $(2 \mathrm{~mm}$ x $2 \mathrm{~mm}$ $\mathrm{x} 1 \mathrm{~mm}$ deep, $\mathrm{n}=4$ samples) were drilled out of the stalagmite using a vertical drill press. The powders were mixed with glue and water and affixed to a glass microscope slide.

Initial XRD analysis of two samples from visually identical areas showed that the white, fibrous texture present in the vast majority of the stalagmite (Figure 4 ) is either $100 \%$ calcite or calcite with $1.5 \%$ iron oxide. The small amount of iron is consistent with darker, orange-brown borders present between each growth layer; because this border is very thin (less than $0.5 \mathrm{~mm}$ thick), the sample with $100 \%$ calcite must have excluded it, or had so little iron oxide that it was undetectable. The orange borders are present throughout the stalagmite, which suggests a constant source of iron oxides to the ground water, as opposed to a sudden flooding event or other temporary deposit.

These XRD results, clear growth banding, and closed-system behavior seen in U-series dating results suggests that the mineralogy is primary columnar calcite that has not be impacted by 
significant recrystallization or dissolution (Perrin et al., 2014). The exception to this conclusion is the pores or voids present near the central growth axis of the stalagmite (Figure A2), which were avoided during proxy sampling. When $\mathrm{U} / \mathrm{Th}$ dates fell within $5 \mathrm{~mm}$ of these pitting features, the dates were not used (Figure A2).
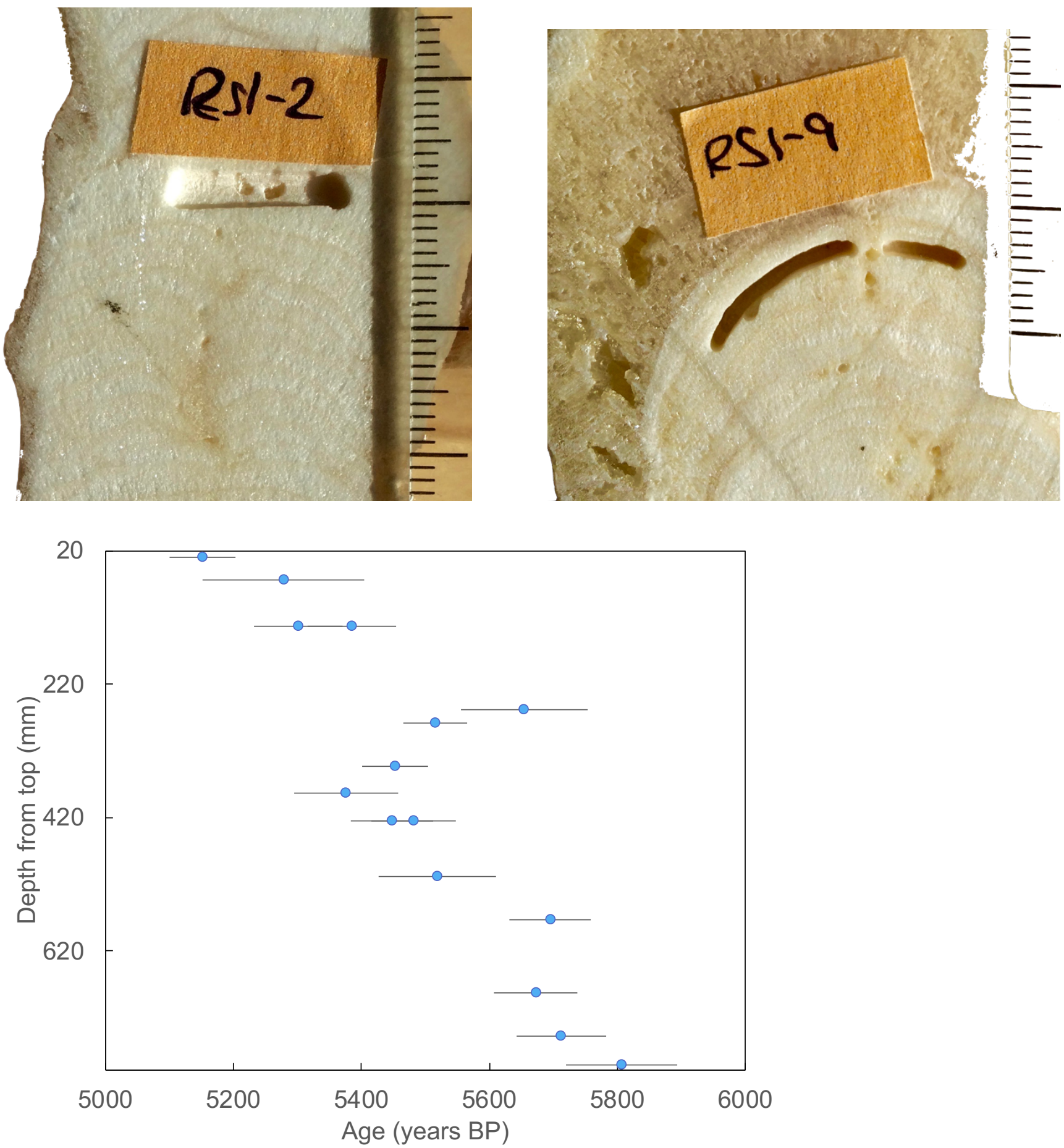

Figure A2. Top: Images of RS1 with examples of vertical pitting, possibly due to calcite dissolution, within $5 \mathrm{~mm}$ of a U/Th dating sample (horizontal pits labeled RS1-2 and RS1-9). 
These U/Th samples were not used because of their proximity to the dissolution features. Ruler shows mm-scale minor ticks. Bottom: Results from $15 \mathrm{U} /$ Th dates, including 5 that were not included in the final age model. Horizontal bars show 2 standard deviations.

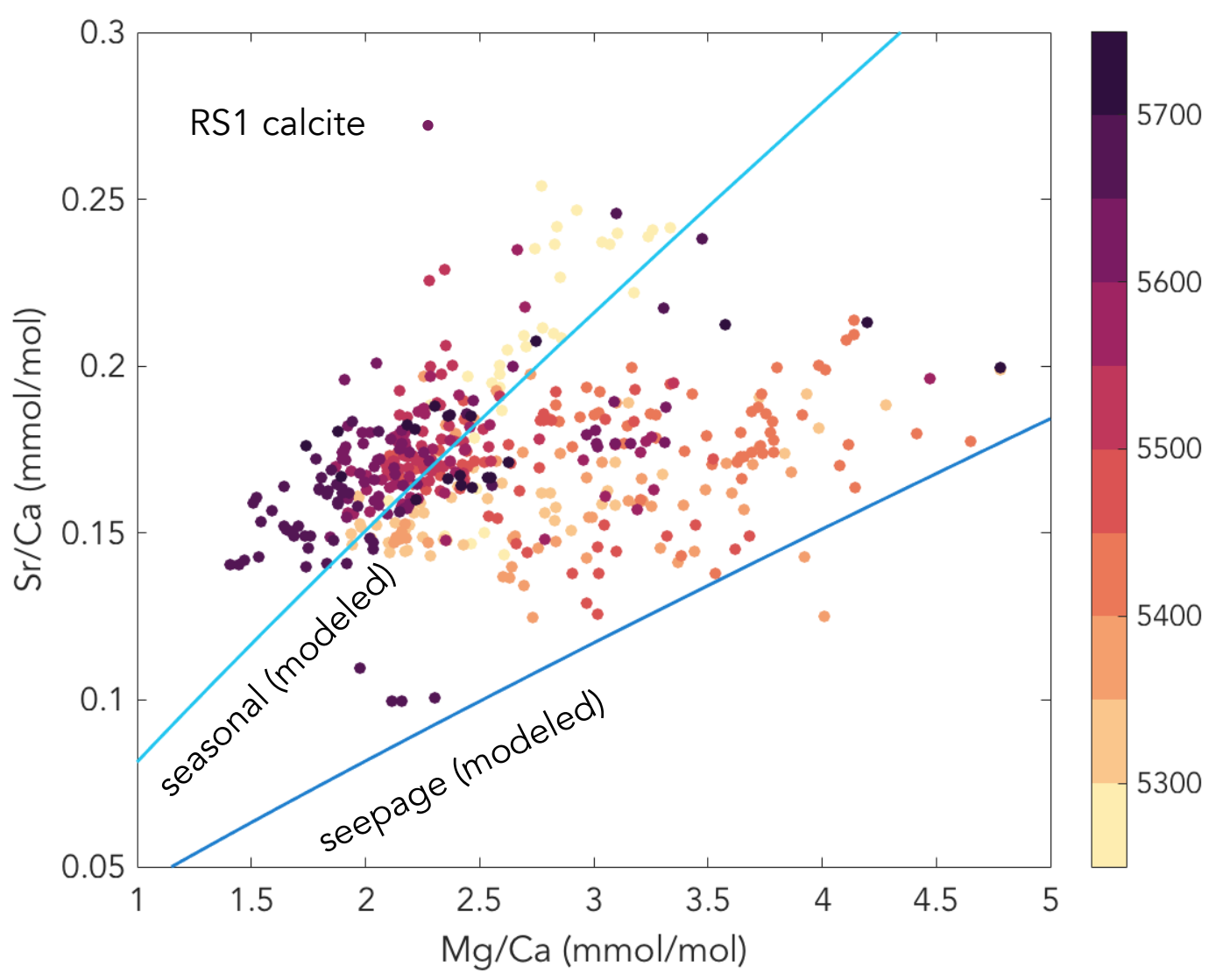

Figure A3. Modeled trace element data for calcite formed from groundwater, seepage-type, and seasonal-type drip water in Río Secreto Cave, compared to measured calcite data from RS1.

This analysis is a rough approximation to check whether the measured $\mathrm{Sr} / \mathrm{Ca}$ and $\mathrm{Mg} / \mathrm{Ca}$ values measured in RS1 are reasonable for Río Secreto Cave. Starting points for modeled drip water were determined based on minimum trace element to calcium ratios measured in the modern water. However, it is likely that mid-Holocene drip waters had lower $\mathrm{Mg} / \mathrm{Ca}$ and $\mathrm{Sr} / \mathrm{Ca}$ ratios, due to the wetter overall mean state. Qualitatively, there is a closer match between calcite data and seasonal-type drips, most noticeable for data from $\sim 5700$ and $\sim 5300 \mathrm{yr}$ BP. 


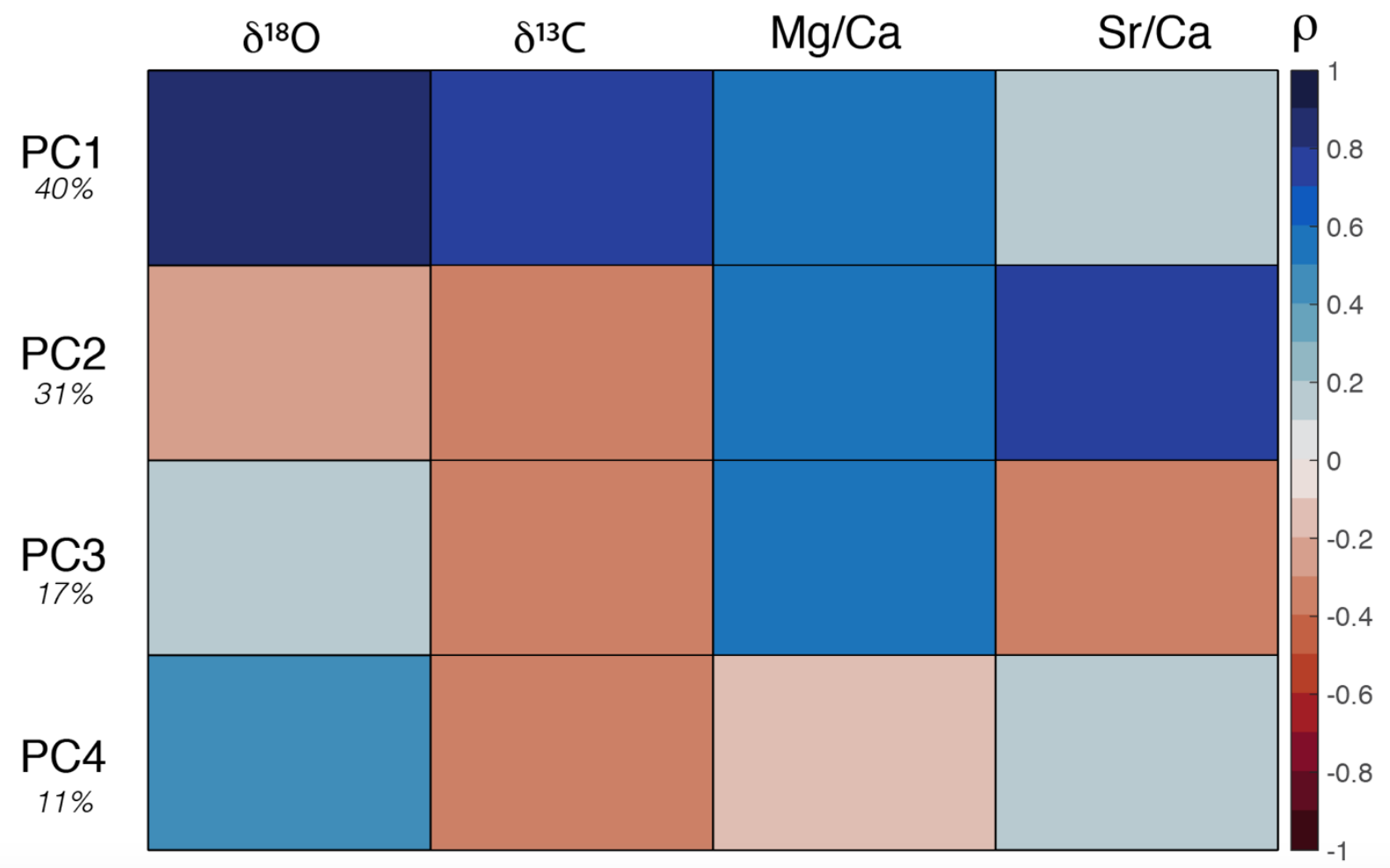

Figure A4. Spearman's rank correlation for geochemical records and principal components (PCs) derived from those records. All correlations were statistically significant ( $p$-value $<<$ 0.01). The variance explained by each $P C$ is noted in italics. 
Appendix B. Data

Table 1. U-Series data for 16 samples from RS1 based on analyses at MIT between 2015 and 2018.

\begin{tabular}{|c|c|c|c|c|c|c|c|c|c|c|c|}
\hline$\underset{\text { ID }}{\text { Sample }}$ & $\begin{array}{c}\text { Depth } \\
\mathrm{mm}\end{array}$ & $\begin{array}{l}{ }^{238} \mathrm{U} \\
\mathrm{ng} / \mathrm{g}\end{array}$ & $\pm 2 \sigma$ & $\begin{array}{c}{ }^{232} \mathrm{Th} \\
\mathrm{pg} / \mathrm{g}\end{array}$ & $\stackrel{ \pm}{2 \sigma}$ & $\begin{array}{c}\mathrm{d}^{234} \mathrm{U} \\
\% 0\end{array}$ & $\begin{array}{c} \pm \\
2 \sigma\end{array}$ & $\begin{array}{l}\left({ }^{230} \mathrm{Th} /\right. \\
\left.{ }^{238} \mathrm{U}\right) \\
\text { activity }\end{array}$ & $\pm 2 \sigma$ & $\begin{array}{l}{ }^{230} \mathrm{Th} / \\
{ }^{232} \mathrm{Th} \\
\mathrm{ppm} \\
\text { atomic }\end{array}$ & $\pm 2 \sigma$ \\
\hline RS1-G1 & 63 & 170 & 3.4 & 1225 & 24.7 & -5 & 2 & 4.95E-02 & $5.30 \mathrm{E}-04$ & 109 & 1.2 \\
\hline RS1-A1 & 133 & 147 & 2.9 & 269 & 5.6 & -2 & 2 & 4.84E-02 & 5.99E-04 & 421 & 4.0 \\
\hline RS1-A2 & 133 & 142 & 2.8 & 606 & 12.4 & -8 & 2 & 4.95E-02 & 5.93E-04 & 184 & 1.6 \\
\hline RS1 $-3^{*}$ & 259 & 119 & 2.0 & 369 & 8.0 & -3 & 3 & $5.16 \mathrm{E}-02$ & 7.00E-04 & 264 & 5 \\
\hline RS1 - 4* & 328 & 134 & 3.0 & 571 & 12.0 & -5 & 7 & 5.93E-02 & $8.00 \mathrm{E}-04$ & 220 & 3 \\
\hline B145 & 343 & 171 & 3.4 & 229 & 4.6 & -5 & 1 & 4.95E-02 & $4.13 \mathrm{E}-04$ & 587 & 5.1 \\
\hline RS1-B1 & 426 & 154 & 3.1 & 153 & 3.3 & -6 & 2 & 4.96E-02 & 5.55E-04 & 795 & 8.3 \\
\hline RS1-B2 & 426 & 158 & 3.2 & 16 & 1.2 & -9 & 2 & $4.89 \mathrm{E}-02$ & $5.49 \mathrm{E}-04$ & 7475 & 547 \\
\hline RS1-G2 & 508 & 142 & 2.8 & 124 & 3.1 & -4 & 1 & $5.00 \mathrm{E}-02$ & $7.84 \mathrm{E}-04$ & 913 & 20 \\
\hline RS1-G3 & 574 & 156 & 3.1 & 69 & 2.6 & -7 & 1 & $5.12 \mathrm{E}-02$ & $5.35 \mathrm{E}-04$ & 1837 & 61 \\
\hline C100 & 684 & 139 & 2.8 & 148 & 3.2 & -5 & 2 & 5.13E-02 & 5.36E-04 & 764 & 10 \\
\hline RS1-G4 & 749 & 134 & 2.7 & 290 & 6.3 & -4 & 2 & $5.20 \mathrm{E}-02$ & $5.29 \mathrm{E}-04$ & 380 & 4.9 \\
\hline RS1-3 & 791 & 160 & 3.2 & 223 & 15.9 & -4.3 & 1.6 & $5.25 \mathrm{E}-02$ & $7.48 \mathrm{E}-04$ & 598 & 41.8 \\
\hline RS1-C1 & 895 & 147 & 2.9 & 549 & 11.0 & 22 & 2 & $5.35 \mathrm{E}-02$ & $5.52 \mathrm{E}-04$ & 227 & 1.2 \\
\hline RS1-C2 & 895 & 135 & 2.7 & 171 & 3.6 & -4 & 2 & $5.80 \mathrm{E}-02$ & $7.46 \mathrm{E}-04$ & 726 & 7.8 \\
\hline RS1 - 4 & 927 & 110 & 2 & 53.1 & 16.9 & 1 & 2 & 5.37E-02 & 1.20E-03 & 1762 & 561 \\
\hline
\end{tabular}

Table 2. U-Series dates $(n=16)$ calculated based on data in Table 1. Ages are given as corrected (corr.) and uncorrected (uncorr.); corrected age in years before present (where present is 1950) was used for age-depth modeling. Dates that were excluded (excl.) or were replicates that were averaged to one date (repl.) are noted in the final two columns. Data span multiple pages.

\begin{tabular}{|c|c|c|c|c|c|c|c|c|c|c|c|}
\hline $\begin{array}{c}\text { Sample } \\
\text { ID }\end{array}$ & $\begin{array}{c}\text { Depth } \\
\mathrm{mm}\end{array}$ & $\begin{array}{c}\text { Uncorr. } \\
\text { Age (yr) }\end{array}$ & $\begin{array}{c}\mathbf{\pm} \\
\mathbf{2 \sigma}\end{array}$ & $\begin{array}{c}\text { Corr. } \\
\text { Age } \\
\text { (yr before } \\
\text { chem.) }\end{array}$ & $\mathbf{\pm 2 \sigma}$ & $\begin{array}{c}\mathbf{d}^{\mathbf{2 3 4} \mathbf{U}} \\
\text { init. } \\
\%\end{array}$ & $\begin{array}{c}\mathbf{\pm} \\
\mathbf{2 \sigma}\end{array}$ & $\begin{array}{c}\text { Corr. } \\
\text { Age } \\
\text { (yr } \\
\text { before } \\
1950)\end{array}$ & $\begin{array}{c}\mathbf{\pm} \\
\mathbf{2 \sigma}\end{array}$ & Excl & Repl \\
\hline RS1-G1 & 63 & 5564 & 62 & 5345 & 126 & -4.8 & 1.8 & 5280 & 126 & & \\
\hline RS1-A1 & 133 & 5423 & 69 & 5368 & 29 & -1.8 & 1.8 & 5300 & 70 & & Y \\
\hline RS1-A2 & 133 & 5581 & 69 & 5451 & 66 & -8.1 & 1.7 & 5390 & 69 & & Y \\
\hline RS1-3 & 259 & 5800 & 90 & 5710 & 100 & -3.0 & 3.0 & 5640 & 100 & Y & \\
\hline RS1-4* & 328 & 6700 & 100 & 6570 & 120 & -5.0 & 7.0 & 6500 & 120 & Y & \\
\hline B145 & 343 & 5560 & 48 & 5520 & 52 & -5.1 & 1.0 & 5450 & 52 & & \\
\hline RS1-B1 & 426 & 5578 & 65 & 5548 & 66 & -6.1 & 1.6 & 5480 & 66 & & Y \\
\hline RS1-B2 & 426 & 5517 & 64 & 5514 & 10 & -8.7 & 1.7 & 5450 & 64 & & Y \\
\hline RS1-G2 & 508 & 5611 & 91 & 5584 & 92 & -3.8 & 1.3 & 5520 & 92 & & \\
\hline
\end{tabular}




\begin{tabular}{|c|c|c|c|c|c|c|c|c|c|c|c|}
\hline RS1-G3 & 574 & 5775 & 63 & 5761 & 63 & -7.6 & 1.4 & 5690 & 63 & & \\
\hline C100 & 684 & 5772 & 63 & 5740 & 65 & -4.8 & 1.5 & 5670 & 65 & & \\
\hline RS1-G4 & 749 & 5844 & 62 & 5778 & 70 & -4.3 & 1.8 & 5710 & 70 & & \\
\hline RS1-3 & 791 & 5912 & 87 & 5870 & 23 & -4.4 & 1.6 & 5806 & 87 & & \\
\hline RS1-C1 & 895 & 5867 & 63 & 5756 & 62.9 & 22.0 & 1.7 & 5690 & 63 & Y & Y \\
\hline RS1-C2 & 895 & 6541 & 88 & 6503 & 89.7 & -4.2 & 1.8 & 6440 & 90 & Y & Y \\
\hline RS1-4 & 927 & 6013 & 139 & 5998 & 15 & 0.9 & 2.1 & 5934 & 139 & Y & \\
\hline
\end{tabular}

Table 3. Stable isotope and trace element data for RS1. Age is given as year before present, where present is 1950. Data are organized by increasing depth (measured from the top of the stalagmite) and span multiple pages. Missing data are noted with $\mathrm{NaN}$.

\begin{tabular}{|c|c|c|c|c|c|}
\hline $\begin{array}{c}\text { Depth } \\
\text { mm from top }\end{array}$ & $\begin{array}{c}\text { Age } \\
\text { Year BP }\end{array}$ & $\begin{array}{c}\mathbf{d}^{\mathbf{1 8}} \mathbf{O} \\
\%, \text { VPDB }\end{array}$ & $\begin{array}{c}\mathbf{d}^{13} \mathbf{C} \\
\%, \text { VPDB }\end{array}$ & $\begin{array}{l}\text { Mg/Ca } \\
\mathrm{mol} / \mathrm{mol}\end{array}$ & $\begin{array}{c}\text { Sr/Ca } \\
\mathrm{mol} / \mathrm{mol}\end{array}$ \\
\hline 41 & 5264 & -8.84 & -4.86 & $\mathrm{NaN}$ & $\mathrm{NaN}$ \\
\hline 43 & 5266 & -9.14 & -5.16 & 3.18E-03 & 2.36E-04 \\
\hline 45 & 5267 & -8.93 & -5.23 & 3.38E-03 & 2.48E-04 \\
\hline 47 & 5268 & -9.24 & -5.37 & 3.19E-03 & 2.20E-04 \\
\hline 49 & 5269 & -9.33 & -5.65 & 3.02E-03 & 2.38E-04 \\
\hline 51 & 5270 & -9.26 & -5.68 & 3.13E-03 & 2.40E-04 \\
\hline 53 & 5272 & -9.2 & -5.79 & 2.63E-03 & 2.34E-04 \\
\hline 55 & 5273 & $\mathrm{NaN}$ & $\mathrm{NaN}$ & 2.87E-03 & 2.37E-04 \\
\hline 55.5 & 5273 & -8.63 & -5.73 & $\mathrm{NaN}$ & $\mathrm{NaN}$ \\
\hline 57 & 5274 & $\mathrm{NaN}$ & $\mathrm{NaN}$ & $2.75 \mathrm{E}-03$ & 2.55E-04 \\
\hline 58 & 5275 & -9.19 & -5.81 & $\mathrm{NaN}$ & $\mathrm{NaN}$ \\
\hline 59 & 5275 & $\mathrm{NaN}$ & $\mathrm{NaN}$ & 2.94E-03 & 2.46E-04 \\
\hline 60.5 & 5276 & -8.23 & -5.71 & $\mathrm{NaN}$ & $\mathrm{NaN}$ \\
\hline 61 & 5276 & $\mathrm{NaN}$ & $\mathrm{NaN}$ & 3.33E-03 & 2.37E-04 \\
\hline 63 & 5278 & -8.25 & -5.86 & 2.89E-03 & 2.36E-04 \\
\hline 65 & 5279 & -9.06 & -5.75 & 2.80E-03 & 2.13E-04 \\
\hline 67 & 5280 & -9.08 & -5.74 & 2.69E-03 & 2.06E-04 \\
\hline 69 & 5281 & -8.77 & -5.5 & 2.88E-03 & 2.09E-04 \\
\hline 71 & 5282 & -8.94 & -5.46 & 2.80E-03 & 2.10E-04 \\
\hline 73 & 5284 & -9.65 & -5.37 & 2.59E-03 & 2.08E-04 \\
\hline 75 & 5285 & -9.6 & -5.51 & 2.59E-03 & 1.84E-04 \\
\hline 77 & 5286 & -9.23 & -5.34 & 2.63E-03 & 2.06E-04 \\
\hline 79 & 5287 & -9.41 & -5.19 & 2.58E-03 & 1.95E-04 \\
\hline 81 & 5289 & -9.06 & -5.41 & 2.60E-03 & 1.93E-04 \\
\hline 83 & 5290 & -8.7 & -5.22 & 2.48E-03 & 1.99E-04 \\
\hline
\end{tabular}




\begin{tabular}{|c|c|c|c|c|c|}
\hline 85 & 5291 & -8.55 & -5.43 & $2.28 \mathrm{E}-03$ & $1.88 \mathrm{E}-04$ \\
\hline 87 & 5292 & -9.43 & -5.72 & $2.54 \mathrm{E}-03$ & 1.76E-04 \\
\hline 89 & 5294 & -8.45 & -5.98 & $2.45 \mathrm{E}-03$ & 1.54E-04 \\
\hline 91 & 5295 & -9 & -6.31 & 2.64E-03 & 1.43E-04 \\
\hline 93 & 5296 & -9.4 & -6.28 & 2.46E-03 & 1.47E-04 \\
\hline 95 & 5297 & -9.34 & -6.23 & $2.31 \mathrm{E}-03$ & 1.50E-04 \\
\hline 97 & 5299 & -9.05 & -6.51 & 2.14E-03 & 1.63E-04 \\
\hline 99 & 5300 & $\mathrm{NaN}$ & $\mathrm{NaN}$ & $2.04 \mathrm{E}-03$ & $1.52 \mathrm{E}-04$ \\
\hline 99.5 & 5300 & -8.82 & -5.98 & $\mathrm{NaN}$ & $\mathrm{NaN}$ \\
\hline 101 & 5301 & $\mathrm{NaN}$ & $\mathrm{NaN}$ & $2.14 \mathrm{E}-03$ & 1.53E-04 \\
\hline 102.5 & 5302 & -9.3 & -6.27 & $\mathrm{NaN}$ & $\mathrm{NaN}$ \\
\hline 103 & 5302 & $\mathrm{NaN}$ & $\mathrm{NaN}$ & 2.19E-03 & $1.50 \mathrm{E}-04$ \\
\hline 105 & 5304 & -9.26 & -6.07 & $2.20 \mathrm{E}-03$ & $1.55 \mathrm{E}-04$ \\
\hline 107 & 5305 & -9.39 & -6.1 & $2.35 \mathrm{E}-03$ & 1.68E-04 \\
\hline 109 & 5306 & -7.31 & -5.29 & $4.66 \mathrm{E}-03$ & 1.92E-04 \\
\hline 111 & 5308 & -8.1 & -4.49 & $2.46 \mathrm{E}-03$ & $1.52 \mathrm{E}-04$ \\
\hline 113 & 5309 & -8.73 & -5.08 & 1.94E-03 & 1.43E-04 \\
\hline 115 & 5310 & -9.43 & -5.4 & 1.97E-03 & 1.62E-04 \\
\hline 117 & 5311 & -9.03 & -5 & 1.97E-03 & 1.60E-04 \\
\hline 119 & 5313 & -8.82 & -5.25 & 1.99E-03 & 1.43E-04 \\
\hline 121 & 5314 & -7.92 & -5.08 & 2.66E-03 & 1.48E-04 \\
\hline 123 & 5315 & -8.25 & -4.86 & 2.29E-03 & 1.48E-04 \\
\hline 125 & 5317 & -8.31 & -4.94 & $2.11 \mathrm{E}-03$ & 1.43E-04 \\
\hline 127.5 & 5318 & -8.32 & -4.97 & 2.10E-03 & $1.48 \mathrm{E}-04$ \\
\hline 130.5 & 5320 & -8.95 & -5.23 & 1.93E-03 & $1.50 \mathrm{E}-04$ \\
\hline 133 & 5322 & -8.68 & -5.15 & 2.02E-03 & $1.55 \mathrm{E}-04$ \\
\hline 135 & 5323 & -7.89 & -5.16 & 3.10E-03 & 1.59E-04 \\
\hline 137 & 5324 & -7.04 & -5.07 & 4.36E-03 & 1.91E-04 \\
\hline 139 & 5326 & -7.96 & -5.26 & $3.44 \mathrm{E}-03$ & 1.93E-04 \\
\hline 141 & 5327 & -8.87 & -5.42 & 2.15E-03 & 1.74E-04 \\
\hline 143 & 5328 & -8.45 & -4.85 & 2.38E-03 & 1.75E-04 \\
\hline 145 & 5330 & -7.15 & -4.82 & $5.10 \mathrm{E}-03$ & 2.07E-04 \\
\hline 147 & 5331 & -8.18 & -5.27 & 3.84E-03 & 1.74E-04 \\
\hline 149 & 5332 & -8.51 & -5.56 & 2.86E-03 & $1.71 \mathrm{E}-04$ \\
\hline 151 & 5334 & -8.93 & -5.85 & 2.35E-03 & $1.59 \mathrm{E}-04$ \\
\hline 153.5 & 5335 & -8.38 & -5.39 & $3.22 \mathrm{E}-03$ & 1.63E-04 \\
\hline 156.5 & 5337 & -8.79 & -5.26 & 2.84E-03 & $1.48 \mathrm{E}-04$ \\
\hline 159 & 5339 & -8.3 & -5.64 & 2.81E-03 & $1.62 \mathrm{E}-04$ \\
\hline 161 & 5340 & -8.96 & -5.98 & 2.76E-03 & 1.62E-04 \\
\hline
\end{tabular}




\begin{tabular}{|c|c|c|c|c|c|}
\hline 163 & 5342 & $\mathrm{NaN}$ & $\mathrm{NaN}$ & 2.91E-03 & 1.54E-04 \\
\hline 163.5 & 5342 & -8.45 & -5.77 & $\mathrm{NaN}$ & $\mathrm{NaN}$ \\
\hline 165 & 5343 & $\mathrm{NaN}$ & $\mathrm{NaN}$ & $2.40 \mathrm{E}-03$ & 1.64E-04 \\
\hline 166 & 5344 & -8.51 & -5.67 & $\mathrm{NaN}$ & $\mathrm{NaN}$ \\
\hline 167 & 5344 & $\mathrm{NaN}$ & $\mathrm{NaN}$ & 2.37E-03 & 1.59E-04 \\
\hline 168.5 & 5345 & -8.82 & -5.84 & $\mathrm{NaN}$ & $\mathrm{NaN}$ \\
\hline 169 & 5346 & $\mathrm{NaN}$ & $\mathrm{NaN}$ & $2.13 E-03$ & 1.53E-04 \\
\hline 171 & 5347 & -9.18 & -5.34 & 2.29E-03 & 1.43E-04 \\
\hline 173 & 5348 & $\mathrm{NaN}$ & $\mathrm{NaN}$ & 2.49E-03 & 1.48E-04 \\
\hline 173.5 & 5349 & -9.26 & -5.86 & $\mathrm{NaN}$ & $\mathrm{NaN}$ \\
\hline 175 & 5350 & $\mathrm{NaN}$ & $\mathrm{NaN}$ & $2.15 \mathrm{E}-03$ & 1.48E-04 \\
\hline 176 & 5350 & -10.25 & -6.83 & $\mathrm{NaN}$ & $\mathrm{NaN}$ \\
\hline 177.5 & 5351 & $\mathrm{NaN}$ & $\mathrm{NaN}$ & 2.12E-03 & 1.47E-04 \\
\hline 178 & 5352 & -9.61 & -6.48 & $\mathrm{NaN}$ & $\mathrm{NaN}$ \\
\hline 180 & 5353 & -9.05 & -5.85 & 2.18E-03 & 1.53E-04 \\
\hline 182 & 5355 & -9.07 & -5.18 & $2.15 \mathrm{E}-03$ & 1.49E-04 \\
\hline 184 & 5356 & -8.63 & -5.3 & 2.23E-03 & 1.48E-04 \\
\hline 186.5 & 5358 & -8.61 & -4.99 & 2.85E-03 & 1.36E-04 \\
\hline 189 & 5359 & -8.96 & -5.4 & 3.33E-03 & 1.63E-04 \\
\hline 191 & 5361 & -7.62 & -4.85 & 4.46E-03 & 1.25E-04 \\
\hline 193 & 5362 & -9.84 & -4.29 & 2.71E-03 & 1.25E-04 \\
\hline 195 & 5363 & -10.12 & -4.85 & 2.68E-03 & 1.38E-04 \\
\hline 197 & 5365 & -10.43 & -5.22 & 2.56E-03 & 1.35E-04 \\
\hline 199 & 5366 & -10.01 & -5.14 & $2.78 \mathrm{E}-03$ & 1.47E-04 \\
\hline 201 & 5368 & -10.28 & -5.44 & 2.57E-03 & $1.50 \mathrm{E}-04$ \\
\hline 203.5 & 5369 & -10.17 & -5.61 & $2.88 \mathrm{E}-03$ & 1.47E-04 \\
\hline 206 & 5371 & -9.45 & -5.73 & 3.09E-03 & 1.90E-04 \\
\hline 208 & 5372 & $\mathrm{NaN}$ & $\mathrm{NaN}$ & 3.49E-03 & 1.49E-04 \\
\hline 208.5 & 5373 & -9.21 & -5.41 & $\mathrm{NaN}$ & $\mathrm{NaN}$ \\
\hline 210 & 5374 & $\mathrm{NaN}$ & $\mathrm{NaN}$ & 3.39E-03 & 1.40E-04 \\
\hline 211 & 5374 & -9.52 & -5.4 & $\mathrm{NaN}$ & $\mathrm{NaN}$ \\
\hline 212 & 5375 & $\mathrm{NaN}$ & $\mathrm{NaN}$ & 3.29E-03 & 1.46E-04 \\
\hline 213.5 & 5376 & -9.14 & -5.12 & $\mathrm{NaN}$ & $\mathrm{NaN}$ \\
\hline 214 & 5376 & $\mathrm{NaN}$ & $\mathrm{NaN}$ & 3.81E-03 & 1.85E-04 \\
\hline 216 & 5378 & -9.45 & -5.82 & 3.59E-03 & $1.61 \mathrm{E}-04$ \\
\hline 218.5 & 5380 & -9.87 & -5.94 & 3.75E-03 & 1.75E-04 \\
\hline 221 & 5381 & -10.2 & -6.36 & 3.01E-03 & 1.56E-04 \\
\hline 223 & 5383 & -9.71 & -5.07 & 2.94E-03 & $1.54 \mathrm{E}-04$ \\
\hline 225.5 & 5385 & -9.67 & -4.99 & $3.28 \mathrm{E}-03$ & 1.60E-04 \\
\hline
\end{tabular}




\begin{tabular}{|c|c|c|c|c|c|}
\hline 228 & 5386 & -10.64 & -5.19 & 3.94E-03 & 1.69E-04 \\
\hline 230 & 5388 & -10.53 & -4.82 & 2.68E-03 & 1.64E-04 \\
\hline 232 & 5389 & -10.59 & -5.5 & 2.72E-03 & 1.98E-04 \\
\hline 234 & 5390 & $\mathrm{NaN}$ & $\mathrm{NaN}$ & 2.52E-03 & 1.91E-04 \\
\hline 234.5 & 5391 & -11.12 & -5.55 & $\mathrm{NaN}$ & $\mathrm{NaN}$ \\
\hline 236 & 5392 & $\mathrm{NaN}$ & $\mathrm{NaN}$ & 2.43E-03 & 1.76E-04 \\
\hline 237 & 5393 & -11.32 & -6 & $\mathrm{NaN}$ & $\mathrm{NaN}$ \\
\hline 238 & 5393 & $\mathrm{NaN}$ & $\mathrm{NaN}$ & $2.23 \mathrm{E}-03$ & $2.00 \mathrm{E}-04$ \\
\hline 239.5 & 5394 & -10.88 & -5.74 & $\mathrm{NaN}$ & $\mathrm{NaN}$ \\
\hline 240 & 5395 & $\mathrm{NaN}$ & $\mathrm{NaN}$ & $2.43 \mathrm{E}-03$ & 1.70E-04 \\
\hline 241.5 & 5396 & $\mathrm{NaN}$ & $\mathrm{NaN}$ & $2.78 \mathrm{E}-03$ & 1.73E-04 \\
\hline 242 & 5396 & -10.69 & -6.38 & $\mathrm{NaN}$ & $\mathrm{NaN}$ \\
\hline 243 & 5397 & $\mathrm{NaN}$ & $\mathrm{NaN}$ & $2.98 \mathrm{E}-03$ & 1.75E-04 \\
\hline 244 & 5397 & -10.17 & -5.98 & $\mathrm{NaN}$ & $\mathrm{NaN}$ \\
\hline 245 & 5398 & $\mathrm{NaN}$ & $\mathrm{NaN}$ & 3.23E-03 & 1.59E-04 \\
\hline 246 & 5399 & -9.1 & -5.65 & $\mathrm{NaN}$ & $\mathrm{NaN}$ \\
\hline 247 & 5399 & $\mathrm{NaN}$ & $\mathrm{NaN}$ & 3.88E-03 & 1.56E-04 \\
\hline 248.5 & 5401 & -8.44 & -4.97 & $\mathrm{NaN}$ & $\mathrm{NaN}$ \\
\hline 249.5 & 5401 & $\mathrm{NaN}$ & $\mathrm{NaN}$ & 4.77E-03 & $1.81 \mathrm{E}-04$ \\
\hline 251.5 & 5403 & -8.86 & -4.24 & 4.13E-03 & 1.79E-04 \\
\hline 253.5 & 5404 & $\mathrm{NaN}$ & $\mathrm{NaN}$ & 4.08E-03 & 1.70E-04 \\
\hline 255.5 & 5405 & -10.05 & -4.67 & 3.84E-03 & 1.92E-04 \\
\hline 257.5 & 5407 & $\mathrm{NaN}$ & $\mathrm{NaN}$ & 2.82E-03 & 1.90E-04 \\
\hline 259 & 5408 & -10.77 & -5.86 & 2.92E-03 & 1.73E-04 \\
\hline 261.5 & 5410 & -11.05 & -6.1 & 3.31E-03 & 1.80E-04 \\
\hline 264 & 5411 & -10.37 & -5.87 & 3.16E-03 & 2.01E-04 \\
\hline 266 & 5413 & -10.63 & -6.04 & $2.96 \mathrm{E}-03$ & $1.88 \mathrm{E}-04$ \\
\hline 268 & 5414 & -10.39 & -5.71 & $\mathrm{NaN}$ & $\mathrm{NaN}$ \\
\hline 273 & 5418 & -10.42 & -5.84 & 3.61E-03 & $1.68 \mathrm{E}-04$ \\
\hline 275 & 5419 & -10.44 & -5.87 & 3.73E-03 & 1.94E-04 \\
\hline 277 & 5421 & -10.21 & -5.72 & $\mathrm{NaN}$ & $\mathrm{NaN}$ \\
\hline 279 & 5422 & -10.18 & -5.65 & $\mathrm{NaN}$ & $\mathrm{NaN}$ \\
\hline 281 & 5423 & -10.06 & -5.65 & 3.80E-03 & 1.72E-04 \\
\hline 283 & 5425 & -9.79 & -5.42 & 3.76E-03 & $2.00 \mathrm{E}-04$ \\
\hline 285 & 5426 & -9.76 & -5.32 & 4.06E-03 & $1.99 \mathrm{E}-04$ \\
\hline 287 & 5428 & -9.58 & -5.12 & 4.14E-03 & $2.15 \mathrm{E}-04$ \\
\hline 289.5 & 5429 & -9.1 & -5.18 & $4.14 \mathrm{E}-03$ & 2.08E-04 \\
\hline 292 & 5431 & -9.75 & -5.54 & 3.67E-03 & 1.85E-04 \\
\hline 294 & 5433 & -9.54 & -5.28 & 3.65E-03 & 1.63E-04 \\
\hline
\end{tabular}




\begin{tabular}{|c|c|c|c|c|c|}
\hline 296 & 5434 & -10 & -5.53 & 3.64E-03 & 1.73E-04 \\
\hline 298.5 & 5436 & -9.67 & -5.43 & 3.80E-03 & 1.79E-04 \\
\hline 301 & 5438 & -10 & -5.07 & 3.71E-03 & 1.72E-04 \\
\hline 303 & 5439 & -9.79 & -4.78 & 3.65E-03 & 1.80E-04 \\
\hline 305 & 5440 & -10.26 & -5.2 & 3.44E-03 & 1.79E-04 \\
\hline 307 & 5442 & -10.81 & -5.32 & 3.00E-03 & 1.96E-04 \\
\hline 309 & 5443 & -10.96 & -5.55 & $2.77 \mathrm{E}-03$ & 1.82E-04 \\
\hline 311 & 5445 & -11.04 & -5.67 & 2.92E-03 & 1.84E-04 \\
\hline 313 & 5446 & -10.74 & -5.06 & 3.00E-03 & $1.85 \mathrm{E}-04$ \\
\hline 315 & 5448 & -10.61 & -5.01 & 3.31E-03 & 1.47E-04 \\
\hline 317 & 5449 & -10.77 & -5.18 & 3.52E-03 & $1.37 \mathrm{E}-04$ \\
\hline 319 & 5450 & -10.35 & -5.38 & $3.72 \mathrm{E}-03$ & 1.53E-04 \\
\hline 321.5 & 5452 & -10.93 & -5.83 & 3.01E-03 & 1.52E-04 \\
\hline 324 & 5454 & -11.03 & -5.9 & 3.02E-03 & 1.40E-04 \\
\hline 326 & 5455 & -11.24 & -6.18 & 3.02E-03 & 1.22E-04 \\
\hline 328.5 & 5457 & -11.14 & -6 & 2.90E-03 & 1.38E-04 \\
\hline 331 & 5459 & -10.26 & -5.71 & $3.26 \mathrm{E}-03$ & 1.50E-04 \\
\hline 333 & 5460 & -9.58 & -5.57 & 3.68E-03 & 1.44E-04 \\
\hline 335 & 5462 & -8.47 & -4.99 & 3.39E-03 & 1.95E-04 \\
\hline 337 & 5463 & -9.25 & -5.23 & 3.17E-03 & 1.93E-04 \\
\hline 339 & 5465 & -9.57 & -5.76 & 3.17E-03 & $1.79 \mathrm{E}-04$ \\
\hline 341 & 5466 & -10.14 & -5.71 & 2.84E-03 & 1.93E-04 \\
\hline 343 & 5467 & -10.18 & -5.68 & $2.77 \mathrm{E}-03$ & $1.81 \mathrm{E}-04$ \\
\hline 345 & 5469 & -10.37 & -5.76 & 2.77E-03 & 1.86E-04 \\
\hline 347 & 5470 & -10.08 & -5.41 & $2.82 \mathrm{E}-03$ & 1.83E-04 \\
\hline 349 & 5472 & -10.52 & -5.73 & $2.51 \mathrm{E}-03$ & $1.72 \mathrm{E}-04$ \\
\hline 351 & 5473 & -10.37 & -5.68 & $2.42 \mathrm{E}-03$ & 1.70E-04 \\
\hline 353 & 5474 & -10.17 & -5.76 & $2.56 \mathrm{E}-03$ & 1.72E-04 \\
\hline 355.5 & 5476 & -9.26 & -5.4 & $2.78 \mathrm{E}-03$ & $1.69 \mathrm{E}-04$ \\
\hline 358 & 5478 & -9.4 & -5.29 & 2.57E-03 & 1.55E-04 \\
\hline 360 & 5479 & -8.8 & -4.97 & $2.75 \mathrm{E}-03$ & 1.41E-04 \\
\hline 362 & 5481 & -10.04 & -5.7 & $\mathrm{NaN}$ & $\mathrm{NaN}$ \\
\hline 364 & 5482 & -9.97 & -5.52 & $2.40 \mathrm{E}-03$ & 1.64E-04 \\
\hline 366 & 5484 & -9.59 & -5.39 & $2.45 \mathrm{E}-03$ & 1.67E-04 \\
\hline 368.5 & 5485 & -9.19 & -5.19 & $2.42 \mathrm{E}-03$ & $1.94 \mathrm{E}-04$ \\
\hline 371 & 5487 & -9.72 & -5.64 & $2.45 \mathrm{E}-03$ & 1.69E-04 \\
\hline 373 & 5489 & -10.28 & -6.1 & 2.27E-03 & 1.66E-04 \\
\hline 375 & 5490 & -10.45 & -6.37 & $2.14 \mathrm{E}-03$ & 1.74E-04 \\
\hline 377 & 5491 & -10.71 & -6.99 & 2.10E-03 & 1.73E-04 \\
\hline
\end{tabular}




\begin{tabular}{|c|c|c|c|c|c|}
\hline 379 & 5493 & -10.77 & -7.19 & $2.10 \mathrm{E}-03$ & $1.71 \mathrm{E}-04$ \\
\hline 381.5 & 5494 & -10.42 & -6.77 & 2.17E-03 & 1.65E-04 \\
\hline 384 & 5496 & -10.03 & -6.21 & $2.28 \mathrm{E}-03$ & 1.63E-04 \\
\hline 386 & 5498 & -10.11 & -5.78 & 2.35E-03 & 1.76E-04 \\
\hline 388.5 & 5499 & -10.34 & -5.75 & 2.22E-03 & 1.69E-04 \\
\hline 391 & 5501 & -9.95 & -5.76 & 2.32E-03 & 1.71E-04 \\
\hline 393 & 5503 & -9.53 & -5.35 & 2.43E-03 & 1.81E-04 \\
\hline 395 & 5504 & -10.15 & -5.64 & 2.17E-03 & 1.73E-04 \\
\hline 397 & 5505 & -9.98 & -5.67 & $2.28 \mathrm{E}-03$ & $1.68 \mathrm{E}-04$ \\
\hline 399 & 5507 & -10.25 & -5.55 & $2.22 \mathrm{E}-03$ & 1.73E-04 \\
\hline 401 & 5508 & -9.17 & -5.15 & $2.44 \mathrm{E}-03$ & $1.64 \mathrm{E}-04$ \\
\hline 403 & 5510 & -9.1 & -5.27 & 2.60E-03 & 1.75E-04 \\
\hline 405.5 & 5511 & -9.52 & -5.47 & $2.41 \mathrm{E}-03$ & 1.78E-04 \\
\hline 408 & 5513 & -8.98 & -5.13 & 2.33E-03 & 1.62E-04 \\
\hline 410 & 5514 & -9 & -5.42 & $2.26 \mathrm{E}-03$ & 1.67E-04 \\
\hline 412 & 5516 & -8.56 & -5.42 & 2.32E-03 & 1.71E-04 \\
\hline 414 & 5517 & -9.22 & -5.66 & $2.44 \mathrm{E}-03$ & 1.68E-04 \\
\hline 416 & 5519 & -9.83 & -5.89 & $2.25 \mathrm{E}-03$ & $1.71 \mathrm{E}-04$ \\
\hline 418 & 5520 & -9.62 & -5.7 & $2.08 \mathrm{E}-03$ & 1.66E-04 \\
\hline 420 & 5521 & $\mathrm{NaN}$ & $\mathrm{NaN}$ & 2.30E-03 & 1.74E-04 \\
\hline 420.5 & 5522 & -9.09 & -5.32 & $\mathrm{NaN}$ & $\mathrm{NaN}$ \\
\hline 423.5 & 5524 & -9.89 & -5.09 & $\mathrm{NaN}$ & $\mathrm{NaN}$ \\
\hline 424 & 5524 & $\mathrm{NaN}$ & $\mathrm{NaN}$ & $2.09 \mathrm{E}-03$ & 1.69E-04 \\
\hline 426 & 5525 & $\mathrm{NaN}$ & $\mathrm{NaN}$ & 2.09E-03 & 1.71E-04 \\
\hline 427 & 5526 & -9.55 & -4.78 & $\mathrm{NaN}$ & $\mathrm{NaN}$ \\
\hline 430 & 5528 & -8.74 & -4.92 & 2.63E-03 & 1.94E-04 \\
\hline 432 & 5530 & -9.73 & -5.53 & $2.21 \mathrm{E}-03$ & 1.75E-04 \\
\hline 434.5 & 5531 & -9.79 & -5.52 & $2.25 \mathrm{E}-03$ & 1.64E-04 \\
\hline 437 & 5533 & -8.47 & -4.92 & 3.39E-03 & 1.96E-04 \\
\hline 439 & 5534 & -10.99 & -5.58 & 2.25E-03 & 1.77E-04 \\
\hline 441 & 5536 & -10.97 & -5.89 & 2.08E-03 & 1.70E-04 \\
\hline 443.5 & 5537 & -10.39 & -5.72 & $2.29 \mathrm{E}-03$ & $1.78 \mathrm{E}-04$ \\
\hline 446 & 5539 & -10.78 & -5.65 & 2.18E-03 & 1.85E-04 \\
\hline 448.5 & 5541 & -10.84 & -5.91 & $2.12 \mathrm{E}-03$ & 1.86E-04 \\
\hline 451 & 5543 & -10.71 & -5.78 & 2.34E-03 & $2.42 \mathrm{E}-04$ \\
\hline 453 & 5544 & -10.73 & -5.94 & $2.35 \mathrm{E}-03$ & 2.07E-04 \\
\hline 455 & 5545 & -10.54 & -6.12 & 2.30E-03 & $1.84 \mathrm{E}-04$ \\
\hline 457 & 5547 & -10.68 & -5.95 & $2.38 \mathrm{E}-03$ & 1.97E-04 \\
\hline 459 & 5548 & -10.76 & -6.01 & 2.40E-03 & $2.24 \mathrm{E}-04$ \\
\hline
\end{tabular}




\begin{tabular}{|c|c|c|c|c|c|}
\hline 461 & 5549 & -10.36 & -5.79 & $2.21 \mathrm{E}-03$ & $1.84 \mathrm{E}-04$ \\
\hline 463 & 5551 & -10.59 & -6.6 & 2.29E-03 & 1.90E-04 \\
\hline 465 & 5552 & -11.02 & -6.39 & $2.18 \mathrm{E}-03$ & 1.75E-04 \\
\hline 467 & 5553 & -10.57 & -5.96 & 2.13E-03 & 1.78E-04 \\
\hline 469 & 5555 & -10.54 & -6.31 & 2.21E-03 & 1.82E-04 \\
\hline 471 & 5556 & -9.71 & -5.87 & $2.28 \mathrm{E}-03$ & 1.97E-04 \\
\hline 473 & 5557 & -9.46 & -5.93 & 2.63E-03 & $1.78 \mathrm{E}-04$ \\
\hline 475 & 5559 & -9.71 & -5.34 & 2.77E-03 & $2.57 \mathrm{E}-04$ \\
\hline 477 & 5560 & -9.79 & -5.22 & 2.37E-03 & 1.72E-04 \\
\hline 479 & 5561 & -7.97 & -4.79 & 2.34E-03 & 1.59E-04 \\
\hline 481 & 5563 & -6.95 & -4.65 & $\mathrm{NaN}$ & $\mathrm{NaN}$ \\
\hline 481.5 & 5563 & $\mathrm{NaN}$ & $\mathrm{NaN}$ & 4.49E-03 & 1.97E-04 \\
\hline 483 & 5564 & -9.62 & -4.59 & $\mathrm{NaN}$ & $\mathrm{NaN}$ \\
\hline 484 & 5565 & $\mathrm{NaN}$ & $\mathrm{NaN}$ & $2.20 \mathrm{E}-03$ & 1.64E-04 \\
\hline 485.5 & 5566 & -9.49 & -4.55 & $\mathrm{NaN}$ & $\mathrm{NaN}$ \\
\hline 486.5 & 5566 & $\mathrm{NaN}$ & $\mathrm{NaN}$ & 2.17E-03 & 1.80E-04 \\
\hline 488.5 & 5568 & -9.58 & -4.7 & $\mathrm{NaN}$ & $\mathrm{NaN}$ \\
\hline 489 & 5568 & $\mathrm{NaN}$ & $\mathrm{NaN}$ & $2.12 \mathrm{E}-03$ & 1.79E-04 \\
\hline 491 & 5569 & -8.99 & -4.3 & $2.44 \mathrm{E}-03$ & $1.78 \mathrm{E}-04$ \\
\hline 493 & 5571 & -8.79 & -3.97 & 2.43E-03 & 1.73E-04 \\
\hline 495 & 5572 & -8.44 & -4.12 & $2.46 \mathrm{E}-03$ & 1.81E-04 \\
\hline 497 & 5573 & -8.57 & -4.18 & $2.40 \mathrm{E}-03$ & 1.94E-04 \\
\hline 499 & 5575 & -8.95 & -4.31 & $2.22 \mathrm{E}-03$ & 1.62E-04 \\
\hline 501 & 5576 & -9.44 & -4.59 & 2.16E-03 & $1.58 \mathrm{E}-04$ \\
\hline 503.5 & 5578 & -9.23 & -4.57 & 2.17E-03 & 1.67E-04 \\
\hline 506 & 5579 & -9 & -4.75 & $\mathrm{NaN}$ & $\mathrm{NaN}$ \\
\hline 506.5 & 5579 & $\mathrm{NaN}$ & $\mathrm{NaN}$ & $2.40 \mathrm{E}-03$ & 1.42E-04 \\
\hline 508 & 5580 & -8.62 & -4.52 & $\mathrm{NaN}$ & $\mathrm{NaN}$ \\
\hline 508.5 & 5581 & $\mathrm{NaN}$ & $\mathrm{NaN}$ & 3.27E-03 & 1.56E-04 \\
\hline 510 & 5582 & -8.56 & -4.72 & 2.98E-03 & 1.60E-04 \\
\hline 512 & 5583 & -8.34 & -5 & 3.26E-03 & 1.63E-04 \\
\hline 514 & 5584 & -8.39 & -4.94 & $3.25 \mathrm{E}-03$ & 1.83E-04 \\
\hline 516 & 5586 & -8.31 & -4.48 & 3.21E-03 & 1.73E-04 \\
\hline 518 & 5587 & -9.29 & -4.84 & 2.43E-03 & $1.70 \mathrm{E}-04$ \\
\hline 520 & 5588 & -9.81 & -5.07 & 2.12E-03 & $1.56 \mathrm{E}-04$ \\
\hline 522 & 5589 & -10.2 & -5.12 & 1.97E-03 & 1.56E-04 \\
\hline 524 & 5591 & -10.2 & -5.34 & $1.92 \mathrm{E}-03$ & 1.55E-04 \\
\hline 526.5 & 5592 & -10.66 & -5.5 & $1.92 \mathrm{E}-03$ & $1.62 \mathrm{E}-04$ \\
\hline 529 & 5594 & -10.23 & -5.43 & 2.11E-03 & 1.64E-04 \\
\hline
\end{tabular}




\begin{tabular}{|c|c|c|c|c|c|}
\hline 531 & 5595 & -10.16 & -5.51 & $2.13 \mathrm{E}-03$ & 1.65E-04 \\
\hline 533 & 5596 & -9.83 & -5.2 & $\mathrm{NaN}$ & $\mathrm{NaN}$ \\
\hline 535 & 5598 & -9.84 & -5.19 & $\mathrm{NaN}$ & $\mathrm{NaN}$ \\
\hline 537 & 5599 & -10.15 & -5.14 & $\mathrm{NaN}$ & $\mathrm{NaN}$ \\
\hline 538 & 5600 & $\mathrm{NaN}$ & $\mathrm{NaN}$ & 1.83E-03 & 1.71E-04 \\
\hline 539 & 5600 & -10.42 & -5.44 & $\mathrm{NaN}$ & $\mathrm{NaN}$ \\
\hline 539.5 & 5601 & $\mathrm{NaN}$ & $\mathrm{NaN}$ & 2.04E-03 & 1.50E-04 \\
\hline 541 & 5602 & -9.84 & -5.44 & $2.16 \mathrm{E}-03$ & 1.62E-04 \\
\hline 542.5 & 5602 & $\mathrm{NaN}$ & $\mathrm{NaN}$ & 2.22E-03 & 1.84E-04 \\
\hline 543 & 5603 & -9.85 & -5.57 & $\mathrm{NaN}$ & $\mathrm{NaN}$ \\
\hline 544 & 5603 & $\mathrm{NaN}$ & $\mathrm{NaN}$ & $3.41 \mathrm{E}-03$ & 1.77E-04 \\
\hline 545 & 5604 & -8.12 & -5.28 & $\mathrm{NaN}$ & $\mathrm{NaN}$ \\
\hline 547 & 5605 & -8.06 & -5.21 & $\mathrm{NaN}$ & $\mathrm{NaN}$ \\
\hline 549 & 5607 & -6.1 & -5.13 & 2.94E-03 & 1.77E-04 \\
\hline 551 & 5608 & -8.53 & -5.49 & $3.12 \mathrm{E}-03$ & 1.75E-04 \\
\hline 553 & 5609 & -8.69 & -5.7 & 2.66E-03 & 2.00E-04 \\
\hline 555 & 5610 & -8.12 & -5.17 & $2.44 \mathrm{E}-03$ & 1.88E-04 \\
\hline 556.5 & 5611 & -9.22 & -5.35 & 3.17E-03 & 1.76E-04 \\
\hline 559 & 5613 & -8.47 & -5.25 & 3.42E-03 & 1.96E-04 \\
\hline 561 & 5614 & -9.93 & -5.69 & 2.30E-03 & 1.73E-04 \\
\hline 563 & 5615 & -10.23 & -5.7 & $2.16 \mathrm{E}-03$ & 1.64E-04 \\
\hline 565 & 5616 & -10.27 & -5.77 & 2.12E-03 & 1.69E-04 \\
\hline 567 & 5618 & -10.28 & -5.86 & 2.17E-03 & 1.80E-04 \\
\hline 569 & 5619 & -10.13 & -5.77 & 2.14E-03 & 1.82E-04 \\
\hline 571 & 5620 & -9.89 & -5.72 & $2.20 \mathrm{E}-03$ & 1.57E-04 \\
\hline 573 & 5621 & -10.07 & -5.86 & $2.03 E-03$ & 2.07E-04 \\
\hline 575 & 5622 & -10.06 & -5.85 & $2.08 \mathrm{E}-03$ & 1.57E-04 \\
\hline 577 & 5624 & -10.13 & -5.83 & $2.01 \mathrm{E}-03$ & 1.62E-04 \\
\hline 579 & 5625 & -10.08 & -5.83 & 1.93E-03 & 1.78E-04 \\
\hline 581 & 5626 & -10.11 & -5.71 & 1.90E-03 & 1.97E-04 \\
\hline 583 & 5627 & -9.9 & -5.61 & 2.07E-03 & 1.69E-04 \\
\hline 585 & 5628 & -10.3 & -5.92 & $1.84 \mathrm{E}-03$ & $1.76 \mathrm{E}-04$ \\
\hline 587 & 5630 & -9.95 & -5.98 & 1.94E-03 & 1.69E-04 \\
\hline 589 & 5631 & -9.86 & -6.08 & $2.06 \mathrm{E}-03$ & 1.60E-04 \\
\hline 591 & 5632 & -9.86 & -6.15 & 2.04E-03 & 1.64E-04 \\
\hline 593 & 5633 & -9.86 & -6.27 & 1.99E-03 & 1.77E-04 \\
\hline 595 & 5634 & -9.58 & -6.26 & 2.05E-03 & 1.68E-04 \\
\hline 597 & 5635 & -9.5 & -6.31 & 2.14E-03 & 1.83E-04 \\
\hline 599 & 5637 & -10.05 & -6.27 & 1.91E-03 & 1.78E-04 \\
\hline
\end{tabular}




\begin{tabular}{|c|c|c|c|c|c|}
\hline 601 & 5638 & -10.16 & -6.34 & 1.88E-03 & 1.68E-04 \\
\hline 603 & 5639 & -9.87 & -6.12 & 2.00E-03 & 1.81E-04 \\
\hline 605 & 5640 & -10.05 & -6.19 & 1.91E-03 & 1.76E-04 \\
\hline 607 & 5641 & -9.39 & -5.79 & 2.15E-03 & 1.69E-04 \\
\hline 609 & 5642 & -9.01 & -5.69 & $2.29 E-03$ & 1.76E-04 \\
\hline 611 & 5643 & -9.85 & -5.86 & 2.19E-03 & $1.58 \mathrm{E}-04$ \\
\hline 615 & 5646 & $\mathrm{NaN}$ & $\mathrm{NaN}$ & 2.16E-03 & 1.57E-04 \\
\hline 616.5 & 5647 & $\mathrm{NaN}$ & $\mathrm{NaN}$ & 1.88E-03 & $1.60 \mathrm{E}-04$ \\
\hline 617.5 & 5647 & -10.5 & -6.38 & $\mathrm{NaN}$ & $\mathrm{NaN}$ \\
\hline 618 & 5647 & $\mathrm{NaN}$ & $\mathrm{NaN}$ & 1.96E-03 & 1.60E-04 \\
\hline 620 & 5649 & $\mathrm{NaN}$ & $\mathrm{NaN}$ & $1.88 \mathrm{E}-03$ & 1.50E-04 \\
\hline 620.5 & 5649 & -10.35 & -6.13 & $\mathrm{NaN}$ & $\mathrm{NaN}$ \\
\hline 621.5 & 5649 & $\mathrm{NaN}$ & $\mathrm{NaN}$ & 1.83E-03 & $1.48 \mathrm{E}-04$ \\
\hline 622.5 & 5650 & $\mathrm{NaN}$ & $\mathrm{NaN}$ & 1.93E-03 & $1.40 \mathrm{E}-04$ \\
\hline 623 & 5650 & -10.19 & -6.12 & $\mathrm{NaN}$ & $\mathrm{NaN}$ \\
\hline 625 & 5651 & $\mathrm{NaN}$ & $\mathrm{NaN}$ & 1.84E-03 & $1.50 \mathrm{E}-04$ \\
\hline 625.5 & 5652 & -10.45 & -6.21 & $1.72 \mathrm{E}-03$ & 1.49E-04 \\
\hline 628 & 5653 & -10.89 & -6.39 & $\mathrm{NaN}$ & $\mathrm{NaN}$ \\
\hline 629 & 5654 & $\mathrm{NaN}$ & $\mathrm{NaN}$ & 1.66E-03 & $1.50 \mathrm{E}-04$ \\
\hline 630.5 & 5654 & -10.7 & -6 & $\mathrm{NaN}$ & $\mathrm{NaN}$ \\
\hline 631 & 5655 & $\mathrm{NaN}$ & $\mathrm{NaN}$ & 1.64E-03 & $1.53 \mathrm{E}-04$ \\
\hline 633 & 5656 & -10.66 & -6.01 & 1.65E-03 & $1.50 \mathrm{E}-04$ \\
\hline 635 & 5657 & -11.13 & -6.08 & 1.70E-03 & 1.53E-04 \\
\hline 637 & 5658 & -10.25 & -5.64 & 1.73E-03 & $1.50 \mathrm{E}-04$ \\
\hline 639 & 5659 & -9.32 & -5.13 & 1.74E-03 & $1.40 \mathrm{E}-04$ \\
\hline 641 & 5660 & -9.79 & -5.46 & $1.75 E-03$ & 1.46E-04 \\
\hline 643 & 5661 & -9.72 & -5.7 & 1.90E-03 & 1.60E-04 \\
\hline 645 & 5662 & $\mathrm{NaN}$ & $\mathrm{NaN}$ & $1.52 \mathrm{E}-03$ & 1.56E-04 \\
\hline 645.5 & 5663 & -10.02 & -5.73 & $\mathrm{NaN}$ & $\mathrm{NaN}$ \\
\hline 647 & 5663 & $\mathrm{NaN}$ & $\mathrm{NaN}$ & $1.55 \mathrm{E}-03$ & 1.52E-04 \\
\hline 648 & 5664 & -9.65 & -5.36 & 1.92E-03 & $1.68 \mathrm{E}-04$ \\
\hline 650.5 & 5665 & -8.28 & -5.13 & $\mathrm{NaN}$ & $\mathrm{NaN}$ \\
\hline 653 & 5666 & -8 & -4.6 & 2.03E-03 & $1.45 \mathrm{E}-04$ \\
\hline 653.5 & 5667 & $\mathrm{NaN}$ & $\mathrm{NaN}$ & $2.08 E-03$ & 1.49E-04 \\
\hline 655 & 5668 & -7.87 & -4.76 & 1.96E-03 & $1.45 \mathrm{E}-04$ \\
\hline 656.5 & 5668 & $\mathrm{NaN}$ & $\mathrm{NaN}$ & 2.05E-03 & $1.51 \mathrm{E}-04$ \\
\hline 657 & 5669 & -7.22 & -4.42 & $2.78 \mathrm{E}-03$ & $1.71 \mathrm{E}-04$ \\
\hline 660 & 5670 & -7.06 & -4.46 & $\mathrm{NaN}$ & $\mathrm{NaN}$ \\
\hline 661 & 5671 & $\mathrm{NaN}$ & $\mathrm{NaN}$ & 1.56E-03 & 1.43E-04 \\
\hline
\end{tabular}




\begin{tabular}{|c|c|c|c|c|c|}
\hline 663 & 5672 & -7.33 & -4.62 & $\mathrm{NaN}$ & $\mathrm{NaN}$ \\
\hline 665 & 5673 & -7.47 & -4.8 & 1.39E-03 & 1.40E-04 \\
\hline 667 & 5674 & -7.37 & -4.8 & 1.46E-03 & $1.41 \mathrm{E}-04$ \\
\hline 669 & 5675 & -7.66 & -4.95 & 2.13E-03 & 9.98E-05 \\
\hline 671 & 5676 & -7.65 & -5.13 & 2.11E-03 & 9.98E-05 \\
\hline 673 & 5677 & -7.87 & -5.41 & $2.17 \mathrm{E}-03$ & 9.98E-05 \\
\hline 675 & 5678 & -7.19 & -5.02 & 2.35E-03 & $1.01 \mathrm{E}-04$ \\
\hline 677 & 5679 & -7.32 & -5.32 & 1.64E-03 & $1.55 \mathrm{E}-04$ \\
\hline 679 & 5680 & -7.09 & -4.91 & 1.46E-03 & $1.61 \mathrm{E}-04$ \\
\hline 681 & 5681 & -7.72 & -4.95 & 1.54E-03 & 1.61E-04 \\
\hline 683 & 5682 & -7.91 & -5.37 & 1.67E-03 & 1.65E-04 \\
\hline 685 & 5683 & -7.21 & -5 & 3.77E-03 & 2.32E-04 \\
\hline 687 & 5684 & -6.92 & -5.17 & $\mathrm{NaN}$ & $\mathrm{NaN}$ \\
\hline 689 & 5685 & -7.46 & -5.39 & 3.04E-03 & 2.47E-04 \\
\hline 691 & 5686 & -6.75 & -4.97 & $2.52 \mathrm{E}-03$ & 1.88E-04 \\
\hline 693 & 5687 & -7.73 & -5.06 & 2.04E-03 & 1.73E-04 \\
\hline 695.5 & 5688 & -7.42 & -5.18 & 2.08E-03 & $1.91 \mathrm{E}-04$ \\
\hline 698 & 5689 & -7.68 & -5.68 & 1.77E-03 & 1.74E-04 \\
\hline 700 & 5690 & -7.23 & -5.47 & 1.93E-03 & 1.64E-04 \\
\hline 702 & 5691 & -8.33 & -5.52 & 1.81E-03 & 1.61E-04 \\
\hline 704.5 & 5692 & -8.83 & -6.11 & 1.91E-03 & $1.58 \mathrm{E}-04$ \\
\hline 707 & 5693 & -8.92 & -5.84 & 1.81E-03 & 1.64E-04 \\
\hline 709 & 5694 & -8.79 & -5.75 & 1.81E-03 & 1.67E-04 \\
\hline 711 & 5695 & -9.28 & -5.9 & 1.78E-03 & 1.73E-04 \\
\hline 713 & 5696 & -9.64 & -6.03 & 1.87E-03 & 1.65E-04 \\
\hline 715 & 5697 & -9.82 & -6.32 & 1.89E-03 & $1.62 \mathrm{E}-04$ \\
\hline 717 & 5698 & -9.03 & -5.82 & 1.97E-03 & 1.62E-04 \\
\hline 719 & 5699 & -9.23 & -5.99 & 1.78E-03 & 1.63E-04 \\
\hline 721 & 5700 & -9.25 & -5.88 & $1.84 \mathrm{E}-03$ & 1.63E-04 \\
\hline 723 & 5701 & -8.91 & -5.73 & 1.95E-03 & $1.71 \mathrm{E}-04$ \\
\hline 725 & 5701 & -9.29 & -6.08 & 1.83E-03 & $1.86 \mathrm{E}-04$ \\
\hline 727 & 5702 & -9.95 & -6.4 & 1.71E-03 & 1.72E-04 \\
\hline 729 & 5703 & -9.76 & -6.32 & 2.29E-03 & $1.82 \mathrm{E}-04$ \\
\hline 731 & 5704 & -7.12 & -5.45 & $3.55 \mathrm{E}-03$ & $2.13 \mathrm{E}-04$ \\
\hline 733 & 5705 & -6.55 & -4.95 & 4.70E-03 & 1.97E-04 \\
\hline 735 & 5706 & -6.24 & -4.92 & $5.16 \mathrm{E}-03$ & $2.13 \mathrm{E}-04$ \\
\hline 737.5 & 5707 & -8.45 & -5.78 & 2.43E-03 & $2.14 \mathrm{E}-04$ \\
\hline 739 & 5707 & $\mathrm{NaN}$ & $\mathrm{NaN}$ & $2.20 \mathrm{E}-03$ & 1.65E-04 \\
\hline 740.5 & 5708 & -8.75 & -5.96 & 2.23E-03 & $1.58 \mathrm{E}-04$ \\
\hline
\end{tabular}




\begin{tabular}{|c|c|c|c|c|c|}
\hline 743.5 & 5709 & -8.58 & -5.96 & $2.44 \mathrm{E}-03$ & $1.65 \mathrm{E}-04$ \\
\hline 746.5 & 5711 & -8.53 & -5.73 & $2.44 \mathrm{E}-03$ & $1.67 \mathrm{E}-04$ \\
\hline 749 & 5712 & -8.64 & -5.81 & $\mathrm{NaN}$ & $\mathrm{NaN}$ \\
\hline 751 & 5712 & -7.46 & -4.99 & $2.73 \mathrm{E}-03$ & $1.73 \mathrm{E}-04$ \\
\hline 753 & 5713 & -9.21 & -5.05 & $2.40 \mathrm{E}-03$ & $1.61 \mathrm{E}-04$ \\
\hline 755 & 5714 & -9.18 & -5.31 & $2.52 \mathrm{E}-03$ & $1.65 \mathrm{E}-04$ \\
\hline 757 & 5715 & -8.32 & -5.49 & $2.93 \mathrm{E}-03$ & $2.16 \mathrm{E}-04$ \\
\hline 759 & 5716 & -9.06 & -4.93 & $2.30 \mathrm{E}-03$ & $1.87 \mathrm{E}-04$ \\
\hline 761 & 5716 & -9.3 & -5.26 & $2.43 \mathrm{E}-03$ & $1.84 \mathrm{E}-04$ \\
\hline 763 & 5717 & -9.3 & -5.38 & $2.47 \mathrm{E}-03$ & $1.85 \mathrm{E}-04$ \\
\hline 765 & 5718 & -8.97 & -5.06 & $2.54 \mathrm{E}-03$ & $1.64 \mathrm{E}-04$ \\
\hline 767 & 5719 & -8.78 & -5.11 & $2.60 \mathrm{E}-03$ & $1.83 \mathrm{E}-04$ \\
\hline 769 & 5719 & -9.39 & -5.34 & $2.04 \mathrm{E}-03$ & $1.89 \mathrm{E}-04$ \\
\hline 771 & 5720 & -9.6 & -5.33 & $2.23 \mathrm{E}-03$ & $1.80 \mathrm{E}-04$ \\
\hline 773 & 5721 & -9.87 & -5.17 & $2.02 \mathrm{E}-03$ & $1.88 \mathrm{E}-04$ \\
\hline 775 & 5722 & -10.35 & -5.35 & $\mathrm{NaN}$ & $\mathrm{NaN}$ \\
\hline 777 & 5722 & -10.4 & -5.42 & $\mathrm{NaN}$ & $\mathrm{NaN}$ \\
\hline 779 & 5723 & -10.15 & -5.08 & $\mathrm{NaN}$ & $\mathrm{NaN}$ \\
\hline 781 & 5724 & -9.65 & -5.07 & $\mathrm{NaN}$ & NaN \\
\hline 783 & 5725 & -9.6 & -5.16 & $\mathrm{NaN}$ & NaN \\
\hline 785.5 & 5726 & -10.11 & -5.17 & $\mathrm{NaN}$ & NaN \\
\hline 788 & 5726 & -9.4 & -5.12 & $\mathrm{NaN}$ & $\mathrm{NaN}$ \\
\hline 790.5 & 5727 & -9.39 & -5.53 & $\mathrm{NaN}$ & NaN \\
\hline
\end{tabular}




\title{
Chapter 3: New insights into northern Mexican paleoclimate during the first millennium of the Common Era
}

\begin{abstract}
Northern Mexico is arid, water stressed, and understudied in comparison to southern Mexico. There were major population centers in northern Mexico, including the city of Teotihuacan, that experienced dramatic shifts during the first millennium of the Common Era (CE). We lack precisely dated and high-resolution paleoclimate records to investigate the climate events under which these civilizations survived or collapsed. Previous studies have suggested a dipolar precipitation pattern in Mexico, where northern and southern precipitation are anticorrelated. However, the dipole was nearly impossible to verify without high-resolution datasets from northeast Mexico. In this chapter, I present a precisely dated speleothem from San Luis Potosí, Mexico (289 \pm 13 to $976 \pm 29 \mathrm{CE})$ as a new record of hydroclimatic change. We use stable isotopes and trace metal to calcium ratios to identify several shifts toward drier conditions, including multidecadal droughts peaking at $293 \pm 10,358 \pm 8$, and $566 \pm 11 \mathrm{CE}$. This study confirms anticorrelation between northeast Mexico and the Yucatan Peninsula, as well as the Cariaco Basin, during the first millennium CE. Furthermore, we demonstrate that ENSO was not a major influence on northern Mexican precipitation during this period. We suggest that Atlantic Ocean-based climate drivers are more significant, with positive AMV and positive NAO yielding decreased precipitation.
\end{abstract}

\section{Introduction}

There is great interest in Mesoamerican paleoclimate because of potential connections between Maya civilization and climate (Acuna-Soto et al., 2005; Curtis et al., 1996; Hodell et al., 1995; Hodell, Brenner, \& Curtis, 2005; Hodell et al., 2007; Neff et al., 2006) and future projections of hydrological change due to anthropogenic warming (Hellin et al., 2014; Lee \& Wang, 2014; Williams et al., 2020). Although there are extensive late Holocene records from the Yucatán Peninsula, the scientific community is missing paleoclimate information from northeast (NE) Mexico, which, like the better-studied Yucatán, has been populated for thousands of years (Arnold, 2000; Cuna et al., 2013). NE Mexican records are especially rare in the first millennium of the Common Era, because most tree ring records overlap very little with the first millennium (Cook et al., 2015; Stahle et al., 2011, 2016); the oldest local tree ring record dates to $897 \mathrm{CE}$ (Stahle et al., 2011).

Improving our understanding of NE Mexican paleoclimate is important from both a climate science perspective and an anthropological and cultural lens. As anthropogenic warming proceeds, modeling studies predict that northern Mexico and the southwestern United States will 
experience more droughts and megadroughts by the end of the $21^{\text {st }}$ century (Scheff et al., 2017; Williams et al., 2020). Predictions are robust across all indicators of drought or dryness, including decreased relative humidity and topsoil moisture, more negative (drier) Palmer Drought Severity Index (PDSI), and decreased precipitation (Scheff et al., 2017; Williams et al., 2020). Furthermore, the metropolitan region around San Luis Potosí is already facing declining water quality, water scarcity, and a decreasing groundwater level (Martinez et al., 2011). The region is home to more than 1 million people, and $94 \%$ of urban water comes from the deep aquifer (Martinez et al., 2011). Increased drought in a region that is water-stressed is likely to have significant effects on human populations, food systems, and economies, so it is important that future climate models are as accurate as possible. Paleoclimate data will help refine our understanding of NE Mexican hydroclimate in order to improve future simulations and drought preparedness.

From a historical and anthropological standpoint, important data are missing from the current understanding of NE Mexican history. While connections between climate and civilization have been studied carefully in southern Mexico and Central America, the lack of high-resolution paleoclimate records has precluded exhaustive work in central and northern Mexico; there is, however, some evidence for past climate-induced migration (Park et al., 2019) and extreme weather that affected civilizations in this region. Furthermore, human-generated records and environmental knowledge, from oral histories to illustrations, were systematically destroyed during European colonization of Mexico (Rodríguez-Alegría, 2017). Though scientific research cannot replace those losses, paleoclimatologists can work to improve and expand the body of literature related to environmental pressures on civilizations in this region.

One such civilization was centered at Teotihuacan, an urban center located $\sim 60 \mathrm{~km}$ northeast of modern-day Mexico City. Approximately 125,000-150,000 residents lived in the Teotihuacan valley in the city's apogee (Early Classic period, 100-500 CE) (Acuna-Soto et al., 2005; Mejía Ramón \& Johnson, 2019). They had extensive water management technology, including rain-fed canals, short-term water storage features, and a network of basins for the collection and release of rainwater (Mejía Ramón \& Johnson, 2019). These systems were designed to manage a wet season, which came with the possibility of flooding and erosion, and a dry season, when there was not enough rain to feed crops. There is some evidence that Teotihuacan Valley residents grew amaranth, which grows quickly and is much more drought- 
tolerant than maize (Mejía Ramón \& Johnson, 2019). In short, the city was well-equipped to manage highly seasonal precipitation. However, water could only be stored for a few months, not for years, so annual-scale droughts would still have been significant (Mejía Ramón \& Johnson, 2019). Around $550 \mathrm{CE}$, ceramics and other artifacts indicate that the state collapsed, and population decreased to only 20,000 (Mejía Ramón \& Johnson, 2019). There is no evidence of water management during the Epiclassic period (550-900 CE), leading today's archaeologists to the conclusion that any agriculture was much more rudimentary and vulnerable to climate fluctuations in comparison to the Early Classic (Mejía Ramón \& Johnson, 2019). New records of past hydrological change in this region could help elucidate the relationship between climate and significant points in the history of Teotihuacan.

Although paleoclimate data are currently lacking in the NE Mexican region, it is not because of a lack of sources for samples. In fact, this area has the potential to yield key speleothem-based records of paleoclimate on multiple timescales, as there is widespread karst in San Luis Potosí and Tamaulipas (Figure 1) (Oster et al., 2019). We note that, to our knowledge, there are no published speleothem records from central or northern Mexico, which is a missed opportunity (Figure 1). Wright et al. (in prep.) will present the longest, oldest record of NE Mexican paleoclimate, spanning 4.6-58.5 ka, complementing the higher-resolution, more recent record presented here.

There is rich potential for comparison between other parts of Central America, including the well-studied Yucatán Peninsula, and NE Mexico using speleothem records. This gap in data is especially noticeable in the first millennium of the Common Era; tree rings are rich archives of paleoclimate, but they only go back centuries (Cook et al., 2015; Stahle et al., 2011, 2016), and sediment cores are often at lower resolution and have larger age errors (Hodell, Brenner, Curtis, et al., 2005; Park et al., 2019). 


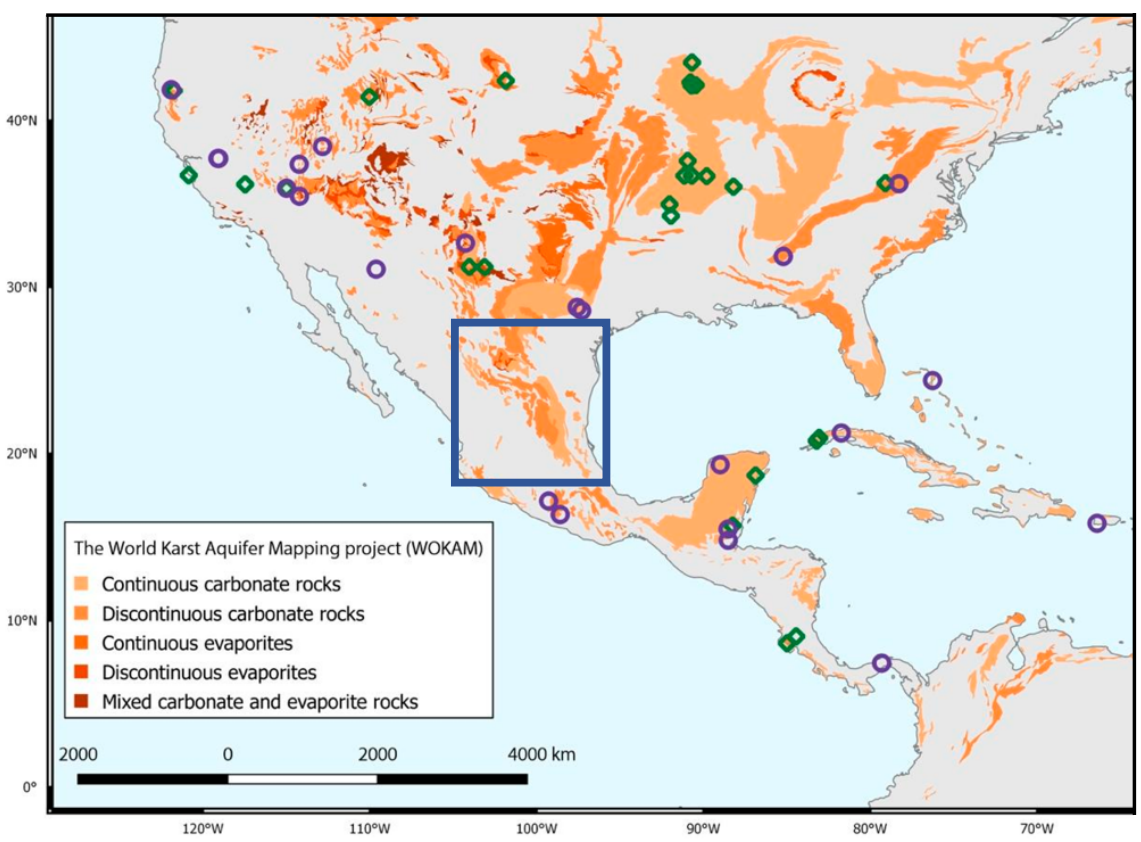

Figure 1. Locations of karst rocks (orange) and published speleothem records (purple and green points). Green points indicate speleothems that have not yet been added to the SISAL database. We note the extensive karst present in NE Mexico (without any published speleothem records) with a blue box. A version of this figure originally appeared in Oster et al. (2019) under a CC BY 4.0 license.

Here we present a new, precisely dated, multiproxy record of Common Era hydroclimate in a speleothem from San Luis Potosí, Mexico. This sample provides a new precipitation record spanning the first millennium of the Common Era, which includes several significant climate and societal periods in the first millennium that are of particular interest. These periods include the Mexican Early Classic Period (100-550 CE), the Mexican Epiclassic Period (550-850 CE), and the Medieval Climate Anomaly (850-1100 CE, MCA). While the Early Classic and Epiclassic periods have been studied extensively from an archaeological point of view, the climate record has primarily come from southern Mexico. Furthermore, the MCA marks clearly documented climate shifts in other parts of the world, but we lack a detailed understanding of how the MCA appears in records of North American hydroclimate, if at all. Finally, most reconstructions of the NAO and AMV are generally focused on the last millennium, and do not overlap very much with the first millennium CE (Trouet et al., 2009), so we are missing basic information about climate drivers during this important historical period. 


\subsection{Existing records and current understanding}

It remains unclear how Mexican hydroclimate responds to climate shifts on multiple timescales, from millennial to interannual, and how that response differs spatially. Although there is a need for further research in northern Mexico to better understand these spatial differences, there are existing paleoclimate records from other parts of Central America that have made great strides toward a clear understanding of Mexican climate. Speleothem, tree ring, lake, and marine sediment records from the Mesoamerican region have been used to examine how the dominant controls on Mexican precipitation - the tropical rain belt, the Caribbean Low-Level Jet (CLLJ), and the North American monsoon - responded to paleoclimatic changes and variability, including SST variations, insolation, glacial-interglacial transitions, and North Atlantic cooling events (Bernal et al., 2011; Davies et al., 2018; Lachniet et al., 2013; MedinaElizalde, Polanco-Martínez, et al., 2016; Park et al., 2017; Roy et al., 2016; Stahle et al., 2011, 2016; Wong et al., 2015b; Wright et al., in prep.). In this section, we will further introduce significant time periods in the first millennium and highlight existing climate research related to those periods.

\subsubsection{Early Classic Period (100 to $550 \mathrm{CE}$ )}

The Early Classic Period, as defined at Teotihuacan, spans 100-550 CE, which coincides with the European-centric Roman Warm Period (Buntgen et al., 2011; Wang et al., 2013). As the Roman Warm Period's name suggests, the PAGES 2k synthesis showed that the Northern Hemisphere's warmest 30-year period in the first millennium of the Common Era was centered at $395 \mathrm{CE}$ (PAGES 2k Consortium et al., 2013). In addition to warming, northern European paleo records also showed increased climate variability from 250 to $600 \mathrm{CE}$ (Buntgen et al., 2011) and cooler, arid conditions during the Migration Period (500-600 CE; sometimes called the Late Antique Ice Age) (Buntgen et al., 2011; Wang et al., 2013). Reconstructions suggest that the North Atlantic Oscillation (NAO) index was positive for most of the Early Classic, with a major shift to neutral conditions at $501 \pm 29 \mathrm{CE}$ (Drake, 2017; Olsen et al., 2012); the NAO index returned to positive at $545 \pm 28 \mathrm{CE}$.

Near the end of the Early Classic, there were two major volcanic eruptions in the tropics, dated precisely to 536 and $540 \mathrm{CE}$ and sometimes referred to as the 536 Dust Veil (Dull et al., 2019; Gautier et al., 2019; Larsen et al., 2008). The combination of the two eruptions produced visible atmospheric dimming that lasted for years and exceptional global cooling captured in 
both tree rings from around the world and ice cores from both poles (Dull et al., 2019; Gautier et al., 2019; Larsen et al., 2008; Pearl et al., 2020). After the 540 CE eruption, the Northern Hemisphere showed cold temperatures until 550 CE (Dull et al., 2019). A recent study identified Ilopango volcano in El Salvador as the likely source of the $540 \mathrm{CE}$ event, during the Tierra Blanca Joven eruption (Dull et al., 2019).

Though we have mentioned several European climate records, there are also paleorecords from Mexico and Belize from this time period. Juxtlahuaca Cave is a well-studied site in Oaxaca (southwestern Mexico) with stalagmites covering the Common Era at high resolution (Lachniet et al., 2012, 2017). A stalagmite from this site (JX-6) showed above average precipitation from $\sim 0$ to $200 \mathrm{CE}$, and variable (both above and below average) precipitation from 200 to $500 \mathrm{CE}$ (Lachniet et al., 2012). In Belize, several records of hydroclimate have been published from Yok Balum Cave, including Yok-I, a stalagmite with stable isotope ratios that were interpreted as recording an anomalously wet climate from 400 to $640 \mathrm{CE}$, partially spanning both the Classic and Epiclassic periods (Kennett et al., 2012). However, another sample from the same cave, Yok-G, showed a short but severe dry period from 400 to $425 \mathrm{CE}$ (Asmerom et al., 2020). A sediment core from central Mexico showed lowest stable isotope records from 100 to $400 \mathrm{CE}$, interpreted to be a wet period in comparison to the rest of the Common Era (Park et al., 2019); however, we note that this core has age model uncertainty on the scale of multiple centuries in this period. Therefore, although there are some periods of agreement in other parts of the paleorecord, the Early Classic was highly variable between and within Mesoamerican precipitation records.

\subsubsection{Mexican Epiclassic Period (550 to $850 \mathrm{CE}$ )}

In this work, we are defining the Epiclassic Period at Teotihuacan as beginning at $550 \mathrm{CE}$ after the collapse of government (Mejía Ramón \& Johnson, 2019) and ending at 850 CE, or the approximate earliest start of the Medieval Climate Anomaly (see following section).

The Juxtlahuaca stalagmite sample recorded increased $\delta^{18} \mathrm{O}$ values, interpreted as dry conditions, from 600 to $900 \mathrm{CE}$, with peak drought occurring around $770 \mathrm{CE}$ (Lachniet et al., 2012, 2017). The site is influenced by both Atlantic and Pacific Ocean forcing; there are droughts during synchronous El Nino-like modes and a positive NAO, and vice versa for wet intervals. Juxtlahuaca also sees precipitation decreases correlated with positive PDO, similar to the effect of ENSO (Lachniet et al., 2017). Similarly, the Yok-G record shows an arid interval 
between 625 and $825 \mathrm{CE}$. The reconstructed NAO index reached its peak first millennium value at $678 \pm 24 \mathrm{CE}$ after increasing rapidly starting at $550 \mathrm{CE}$ (Olsen et al., 2012); it remained high until $750 \pm 29 \mathrm{CE}$. Positive NAO is consistent with, but earlier than, the peak drought at Juxtlahuaca (Lachniet et al., 2012). In general, this period can be thought of as a relatively dry part of the first millennium in southern Mexico, with positive reconstructed NAO. However, we lack data on northeast Mexican hydroclimate at this period.

\subsubsection{Medieval Climate Anomaly (850-1100 CE)}

In the broadest sense, the Medieval Climate Anomaly (MCA) was a warm period in the Northern Hemisphere: reconstructions show that 830-1100 CE was generally anomalously warm, at least where data are present (PAGES 2k Consortium et al., 2013). Although some research has presented the MCA as a coherent feature of the Common Era, PAGES 2k temperature reconstructions (2013) showed that there was no worldwide MCA interval at a decadal scale. Instead, the timing of peak warmth varied globally. Regional studies support this interpretation; for example, Lachniet et al. (2017) suggest that the MCA and the Little Ice Age did not impact southwestern Mexico in the same manner that they did Europe, based on similar z-score means during the two periods. Instead, they found wet conditions at the beginning of the MCA and drought at the end. In contrast, records from the Yucatán Peninsula suggest dry conditions at the beginning of the MCA, with droughts during the Maya Terminal Classic Period (800-1000 CE), causing an estimated $40 \%$ reduction in precipitation in the Yucatán Peninsula during the driest periods (Kennett et al., 2012; Medina-Elizalde \& Rohling, 2012). Furthermore, tree rings from Moctezuma bald cypress in Queretaro, Mexico showed a drought from 897 to 922 CE (Stahle et al., 2011). In Texas, a stalagmite had a growth hiatus during the MCA, interpreted as extremely dry conditions throughout the period (Wong et al., 2015a). It appears that several regions of Mexico experienced dry conditions during the MCA, but the heterogenous timing of MCA droughts showcases the need for a better understanding of what happened in NE Mexico specifically, as insights from other regions don't appear to be generalizable. One open question is whether there was a significant shift in hydroclimate and controls on precipitation around 900 $\mathrm{CE}$, as was found in some records from the Mesoamerican region (Bhattacharya et al., 2015; Graham et al., 2011; Park et al., 2019). 


\subsection{Patterns and drivers of precipitation variability}

It is clear that both Eastern Pacific and North Atlantic Ocean conditions impact Mexican precipitation, but the exact mechanisms, timing, and nature of those impacts are still debated. Model simulations suggest that SST variability produced anti-phased precipitation anomalies over northern and southern Mexico during the Common Era (Bhattacharya et al., 2017). Cooler North Atlantic SSTs lead to increased precipitation in northern Mexico and decreased precipitation in the Yucatán Peninsula and southern Mexico (Bhattacharya et al., 2015, 2017; Bhattacharya \& Chiang, 2014; Rodriguez-Vera et al., 2019; Winter et al., 2015, 2020). The mechanism behind the negative correlation is variability in the CLLJ, where warmer SSTs can decrease the strength of the CLLJ, reducing moisture transport into Mexico (Bhattacharya et al., 2017). The dipolar hypothesis has remained largely untested, however, because of a lack of highresolution samples from northern Mexico (Figure 1).

To review the ocean-hydroclimate connections that have been invoked so far, the major Atlantic modes are the Atlantic Multidecadal Variability (AMV, previously known as Atlantic Multidecadal Oscillation or AMO) and the NAO, while the major Pacific sources of variability are ENSO and PDO. AMV describes shifts in basin-scale Atlantic sea surface temperatures (SST), with the AMV index based on smoothed North Atlantic SST over the instrumental era (Enfield et al., 2001; Knight et al., 2006). Positive AMV indicates that the water near northern Mexico, namely the Caribbean and Gulf of Mexico (GoM), has warmer SST. The AMV helps to show the relationship between Atlantic SST and precipitation in Mesoamerica; for example, there were significantly more hurricanes in the GoM during a positive AMV than a negative phase (Méndez \& Magaña, 2010; Poore et al., 2009). A negative AMV (cooler SST) is connected to wetter conditions in northern Mexico (Bhattacharya et al., 2017) and drier conditions in the Yucatán and Central America (Méndez \& Magaña, 2010; Winter et al., 2020) due to increased moisture transport into Mexico with strengthened CLLJ. The NAO mode describes changes in sea level pressure, where a positive NAO refers to an increased pressure gradient between the Icelandic Low and the North Atlantic Subtropical High (NASH) (Hurrell \& Deser, 2010). Previous work has suggested that a positive NAO mode can increase trade wind strength, decrease SSTs, and generally decrease moisture convergence over the Caribbean region (Bhattacharya et al., 2017; Giannini et al., 2000); therefore, NAO is negatively correlated with precipitation in much of Mexico. 
Changing Pacific modes, including the Pacific Decadal Oscillation (PDO) and El NiñoSouthern Oscillation (ENSO), also have an impact on Mexican precipitation. The PDO and ENSO indices track shifts in Pacific SST on a multi-decadal (PDO) or multi-annual (ENSO) basis. Positive PDO index and El Nino-like conditions are both associated with drying of large portions of Mexico, particularly along the western coast. High Eastern Equatorial Pacific SST leads to tropospheric warming and higher Atlantic SST (Bhattacharya et al., 2017; Giannini et al., 2000; Hunter et al., 2019; Méndez \& Magaña, 2010); this warming is negatively correlated with precipitation in most of Mexico. Some research has indicated that the strength of the ENSO effect on Mexican precipitation is modulated by other factors, such as insolation or cooccurrence with NAO. For example, Park et al. (2019) argue that Common Era precipitation change was driven by ITCZ shifts and ENSO, with droughts coming from strong El Niño-like conditions occurring synchronously with decreased insolation, yielding a southern-shifted ITCZ. Despite several studies that attribute precipitation shifts to ENSO, model-based analysis has failed to demonstrate a clear relationship between ENSO and Mexican precipitation; instead, Bhattacharya et al. (2017) showed that north Atlantic SST is the major driver. More work is required to understand the model-data or model-interpretation disagreement.

Diagnosing paleoclimate variability, or assigning causation to a specific climate mode, is complicated by a lack of certainty in the periodicity for most modes, with the notable exception of ENSO. For example, the instrumental record of AMV shows a significant period of 18-56 years, but paleo-periodicity depends on the type of reconstruction: reconstructions based on a GoM sediment core and tree rings show periods of 34-40 years (Poore et al., 2009), while another study suggests a 70-year period (Park et al., 2017). In summary, AMV, PDO, and NAO all have multidecadal periods, but it is still unclear exactly how long each period is in Mexico.

There are useful reconstructions of these climate modes available during the second millennium of the Common Era (Mann et al., 2009; Stahle et al., 2016; Trouet et al., 2009; Villalba, 1994), but they are virtually nonexistent in the first millennium. Therefore, we focus the analysis in this paper on other paleoclimate records from Mexico and the surrounding regions, rather than specific reconstructions of those modes.

\subsection{Scientific questions and hypotheses}

Given what we know already about Mesoamerican hydroclimate, we can make initial hypotheses about this new NE Mexican record. In this study, we tested the hypothesized dipolar 
hydroclimate in northern Mexico (in comparison to southern Mexico and Central America); more specifically, we investigated whether northern and southern Mexican precipitation records were anticorrelated during the first millennium of the Common Era. Because of the hypothesized dipolar pattern, we investigated whether significant European events (such as the Medieval Climate Anomaly) would be reflected in the NE Mexican record, but we suspected that they may be out of phase or different in response in comparison to other Mesoamerican records. Many records say there was some kind of change in climate regime around $900 \mathrm{CE}$, though the nature and cause remain unclear. We hypothesize that the $900 \mathrm{CE}$ regime change was large enough in spatial scale to appear in NE Mexican records, despite the dipole. Finally, given modern climate and weather, we also posit that NE Mexican precipitation is more closely related to Teotihuacan's precipitation than other sites with high-resolution records, and is therefore a better proxy for its climate history than are southern sites; based on this supposition, we compare our reconstruction to the history of expansion and contraction of settlements at Teotihuacan.

\section{Methods}

\subsection{Cave and setting}

The stalagmite sample, hereafter CP2, was sampled from Cueva de la Puente (CP) in San Luis Potosí, Mexico (21.98N, 100.57W; 2109 meters above sea level). The local geology is dominated by upper Cretaceous limestone and massive fluorite deposits in the El Doctor Platform (González-Partida et al., 2019) with very thin soil cover. The fluorite deposits near CP are the largest in the world (González-Partida et al., 2019). The landscape is arid/semi-arid and the vegetation is scrubland, with yucca trees, agave, and several types of cacti (Lemos-Espinal et al., 2018). CP2 is $30 \mathrm{~cm}$ long with an alternating white and translucent grey texture. The top portion of the stalagmite appeared broken, but the missing piece was not recovered in the area around the stalagmite.

\subsection{Monitoring and rainfall collection}

The majority of the literature on Mexican and Central American paleoclimate assumes that $\delta^{18} \mathrm{O}$ in speleothems is driven primarily by the amount of rainfall, called the "amount effect," which is a safe assumption based on monitoring data and an abundance of speleothems that use this interpretation (Lases-Hernandez et al., 2019; Medina-Elizalde, Burns, et al., 2016; MedinaElizalde \& Rohling, 2012; Oster et al., 2019; Winter et al., 2020). However, northern Mexico is 
closer to Texas than it is to the Peninsula, and $\delta^{18} \mathrm{O}_{\text {precip }}$ in Texas is impacted by shifting moisture sources (Wong et al., 2015a). As part of this study, we will test the hypothesis that, like other parts of Mexico, NE Mexico has a summer wet season with moisture from a single dominant source; if this hypothesis is supported, change in speleothem $\delta^{18} \mathrm{O}$ can be used as a proxy for change in amount of precipitation.

Samples of modern precipitation were collected by Juan Cancino in Rioverde (San Luis Potosí, Mexico), $\sim 55 \mathrm{~km}$ from $\mathrm{CP}$. We used evaporation-limiting precipitation collectors to collect the rain (Wright et al., in prep.), and stored samples in $1.5 \mathrm{ml}$ glass vials with conical inserts. Rain samples were analyzed for $\delta^{18} \mathrm{O}$ and $\delta \mathrm{D}$ at Chapman University. The $\delta^{18} \mathrm{O}$ of rainfall $\left(\delta^{18} \mathrm{O}_{\text {precip }}\right)$ was then averaged to monthly values and compared to CONAGUA rainfall amount data to quantify the amount effect.

\subsection{Trajectory analysis}

Rain-bearing back-trajectories were calculated based on NCEP GDAS one-degree archive data from 2005 to 2008, using HYSPLIT (Stein et al., 2015) and PySPLIT (Warner, 2018). The trajectories were analyzed for 72 hours prior to arrival at $\mathrm{CP}$, after being launched once per day, every day in the winter dry season (DJFM) or the wet summer season (JJAS). We repeated this analysis at the locations of other speleothem records, at Juxtlahuaca in southwestern Mexico (Lachniet et al., 2012, 2017) and Yok Balum in Belize (Asmerom et al., 2020; Baldini et al., 2016; Kennett et al., 2012) (Figure 2 and Appendix).

\subsection{U-Series dating}

We dated 11 horizons along the growth axis of the stalagmite, including 1 set of replicated ages (12 dates). CP2 has a high $U$ concentration (>1000 ng/g calcite), so only $50 \mathrm{mg}$ was necessary for U/Th chemistry. The powders were dissolved, spiked, and processed following methods adapted from Edwards et al. (1987). We eluted U and Th with AG1-X resin and passed the Th fraction through columns a second time to ensure highest possible yield. We analyzed both fractions with a Nu Plasma II multi-collector ICP-MS at MIT.

To create an age-depth model, we used the COPRA algorithm to run 2000 Monte Carlo simulations with PCHIP interpolation (Breitenbach et al., 2012). From these simulations, we extracted the median age model and 95\% confidence interval. 


\subsection{Stable Isotopes and Trace Elements}

CP2 was continuously sampled at MIT using a Sherline micromill at $0.5-2 \mathrm{~mm}$ resolution. After milling, $40-80 \mu \mathrm{g}$ of powder were split and shipped to the UC Irvine Center for Isotope Tracers in Earth Sciences (CITIES). Powders were analyzed on a Kiel IV Carbonate Preparation Device coupled to a Thermo Scientific Delta V-IRMS following methods in McCabe-Glynn et al. (2013) to determine $\delta^{18} \mathrm{O}$ and $\delta^{13} \mathrm{C}$. Samples of unknown composition were interspersed with standards, including NBS-18 and IAEA-CO-1. The analytical precision for $\delta^{18} \mathrm{O}$ and $\delta^{13} \mathrm{C}$ was $0.05 \%$ and $0.02 \%$, respectively. Remaining powdered samples weighing $\sim 1 \mathrm{mg}$ were dissolved in 3\% nitric acid for trace element analysis. $\mathrm{Mg}, \mathrm{Ca}$, and $\mathrm{Sr}$ were measured with an Agilent 7900 at MIT in no-gas mode. Analytical precision was $\sim 3 \%$ and $5 \%$ for $\mathrm{Mg} / \mathrm{Ca}$ and $\mathrm{Sr} / \mathrm{Ca}$ based on standard solutions.

\subsection{Data analysis}

All data analysis was completed with MATLAB version 2018b and Python 3.7, used with Jupyter Lab. We also used a wavelet toolbox for MATLAB (Grinsted et al., 2004) and the Climate Data Toolbox from Greene et al. (2019)

We used code from Tripti Bhattacharya (pers. comm.) to perform a robust empirical orthogonal functions (EOF) analysis, which includes the $95 \% \mathrm{CI}$ high and low age model boundaries in addition to the median age model for each proxy record. We included 4 sites in addition to CP (Asmerom et al., 2020; Davies et al., 2018; Haug et al., 2001; Lachniet et al., 2012); we took the z-scores of all proxies and filtered them with a 5-year low-pass Butterworth filter to reduce high frequency noise and account for differences in proxy behavior.

\section{Results}

In this section, we will begin by describing results from modern precipitation analyses, followed by a report of the geochemical timeseries data from CP2 and neighboring sites of interest. We then show results from spectral analysis and EOF analyses for the same neighboring sites.

\subsection{Modern climatology and monitoring}

We compared GPCC gridded data and a local rain station to find that they record almost identical monthly rainfall (GPCC-CONAGUA mean residual $=7 \mathrm{~mm} / \mathrm{month}$ ) over the past 50 years. Therefore, we assume that published analyses based on GPCC hold true for this specific 
site, which allows us to use an extended instrumental record: GPCC gridded data span 1891 to 2016 CE. Based on these data, we demonstrate that San Luis Potosí (SLP) has a summer wet season, but peak monthly precipitation is 3 to 5 times lower (drier) than southern Mexico (Figure 3). Therefore, we should not expect that northern and southern Mexico recorded precipitation changes the same way, even if they were both impacted by a large-scale climate event. We also note that modern precipitation seasonality and amount at Teotihuacan most closely resembles that of CP, not the southern sites (Figures 2 and 3).

Quantitatively, GPCC summer precipitation at Teotihuacan is more highly correlated to summer precipitation at SLP (Pearson's $r=0.61$, p-value $<<0.001$ ) than to that of Juxtlahuaca (Pearson's $r=0.42, \mathrm{p}$-value $=0.002$ ), though both sites reach statistically significant correlations. Spearman's rank correlation, which does not assume linear relationships, was not significant between Teotihuacan and Juxlahuaca $(\rho=0.25$, $p$-value $=0.081)$, but was significant between Teotihuacan and SLP $(\rho=0.60$, p-value $<<0.001)$. Furthermore, the climatology suggests that the CP2 stalagmite mostly recorded rainfall from April to October, assuming that seasonality has not changed dramatically in the past two millennia (Figure 3). We found that summer precipitation at $\mathrm{CP}$ is anticorrelated with precipitation in the Yucatán and Belize (Figure 2B). As expected, precipitation was most highly correlated with regions closest to CP, especially to the East/the Atlantic side (Figure 2B). This pattern was similar in correlations with Teotihuacan (Appendix).

Trajectory analysis showed that summer (wet season) moisture comes primarily from the Gulf of Mexico and Caribbean Sea (Figure 4). Though there are a few tracks from the Pacific, the parcels that come from the Pacific have very low moisture by the time they reach SLP.

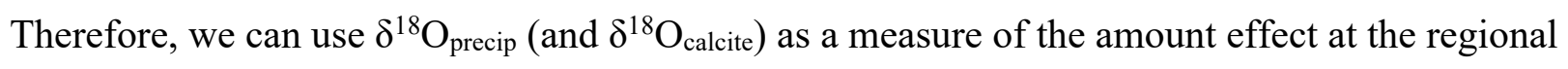
scale. Although it is possible that moisture source has changed over time, the amount effect has been demonstrated in several stalagmites and sediment cores over several millennia in Mexico (e.g. Bernal et al., 2011; Lachniet et al., 2012, 2017; Medina-Elizalde et al., 2016; MedinaElizalde \& Rohling, 2012). In addition, rainfall collected locally demonstrated a high correlation between precipitation amount and $\delta^{18} \mathrm{O}$, which supports the results from the trajectory analyses.

When we repeated the trajectory analysis for Juxtlahuaca and Yok Balum (Appendix), we found significant differences in comparison to the moisture trajectories observed at $\mathrm{CP}$. Juxtlahuaca precipitation has a similar seasonality, with very little moisture during the NH 
winter, but rain parcels travel from both the Pacific Ocean and the Atlantic/Gulf of Mexico. Yok Balum's rainfall is primarily Atlantic-derived, but the seasonality is very different: there are still many moisture-bearing trajectories in the winter; the dominant trajectory path also changes from the winter to the summer wet season (Appendix). These results demonstrate the importance of $\mathrm{CP} 2$ as a proxy record, as it is possible that CP2 is the most closely linked to summer, Atlanticderived rainfall of these three sites.

In summary, we have a clear understanding of the control(s) on $\delta^{18} \mathrm{O}_{\text {precip }}$ above the cave and can safely proceed with the assumption that $\delta^{18} \mathrm{O}_{\text {calcite }}$ is a proxy for paleo rainfall amount. If the $\delta^{13} \mathrm{C}$ and $\mathrm{Mg} / \mathrm{Ca}$ ratios match up with $\delta^{18} \mathrm{O}$, it would suggest that all three are controlled by hydroclimate.

Figure 2. Modern precipitation in northeast Mexico. A. Location of field site, Cueva de la Puente (CP), with wet season (JJAS) precipitation based on GPCC $0.5 \times$ x 0.5-degree V2018 averaged from 1891-2016 CE (Schneider et al., 2015). B. Spatial correlation between JJAS precipitation at CP and elsewhere from 1950-2000 CE, based on GPCC data. C. Comparison of GPCC data with rainfall data from the CONAGUA station closest to CP (La Salitrera, San Luis Potosí). The average residual was $7 \mathrm{~mm} / \mathrm{month}$, suggesting that GPCC precipitation amount reflects local precipitation at the cave site. D. Relationship between precipitation amount and $\delta^{18} \mathrm{O}_{\text {precip }}$ ("amount effect") in northeast Mexico. Each point averages one month of precipitation in 2018 (May - September). 
A. Mean monthly wet season (JJAS) precipitation

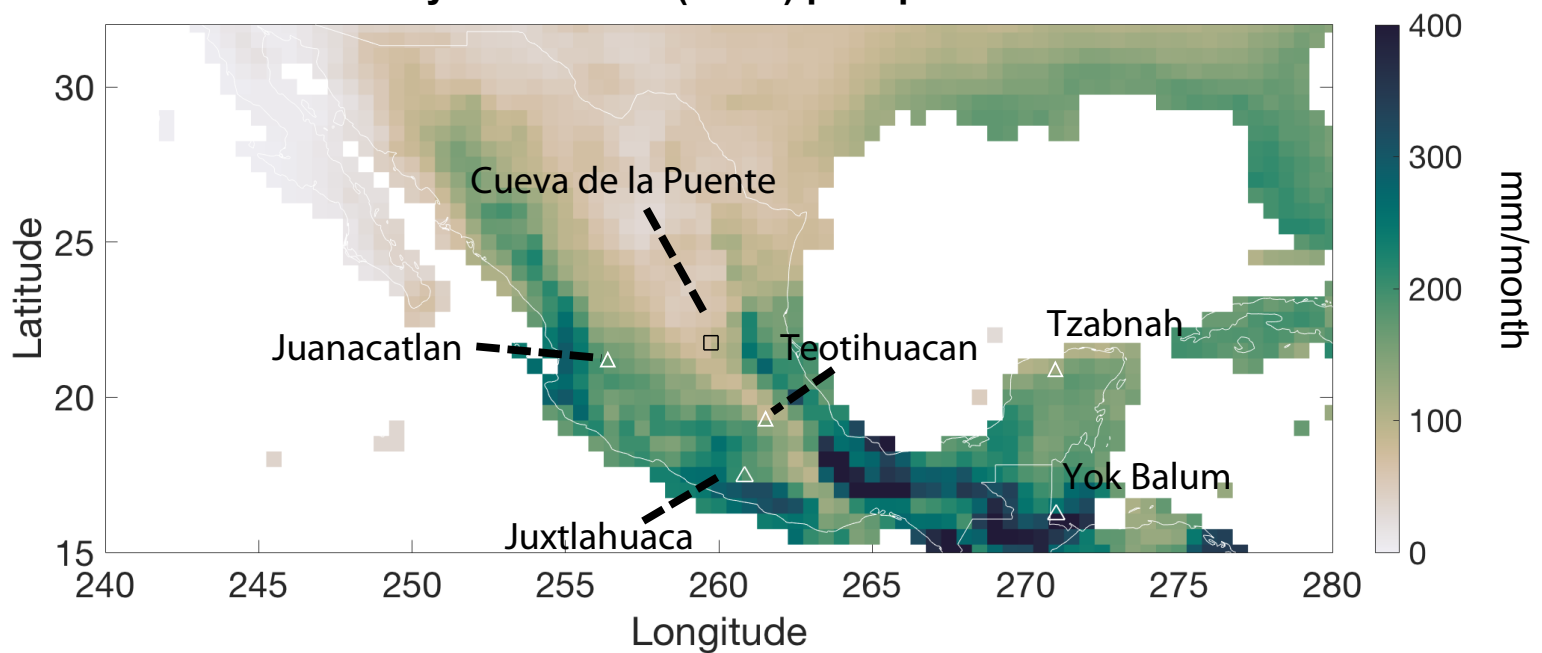

B. Correlation with mean monthly wet season (JJAS) precip. at CP, 1950 - 2000
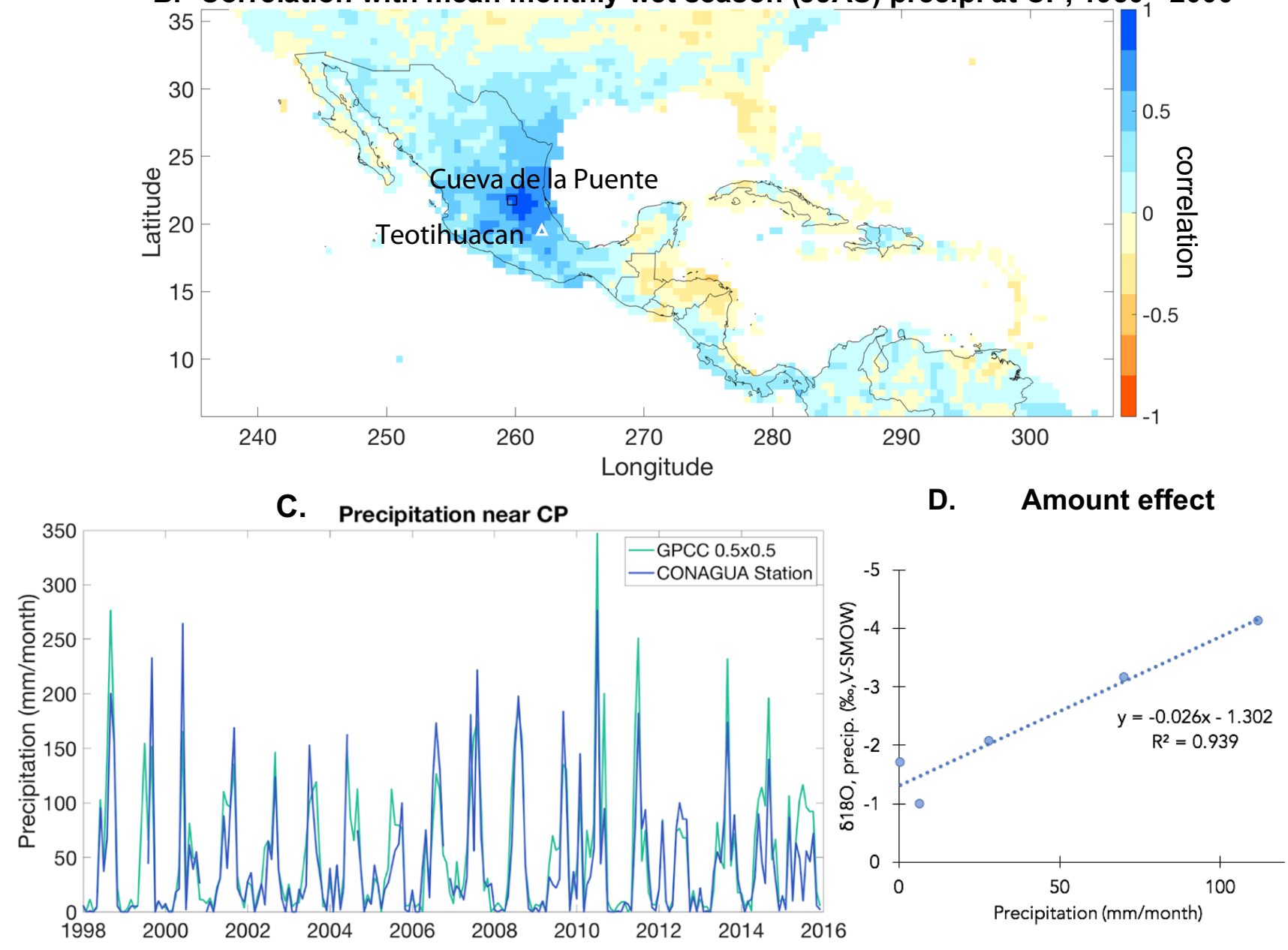


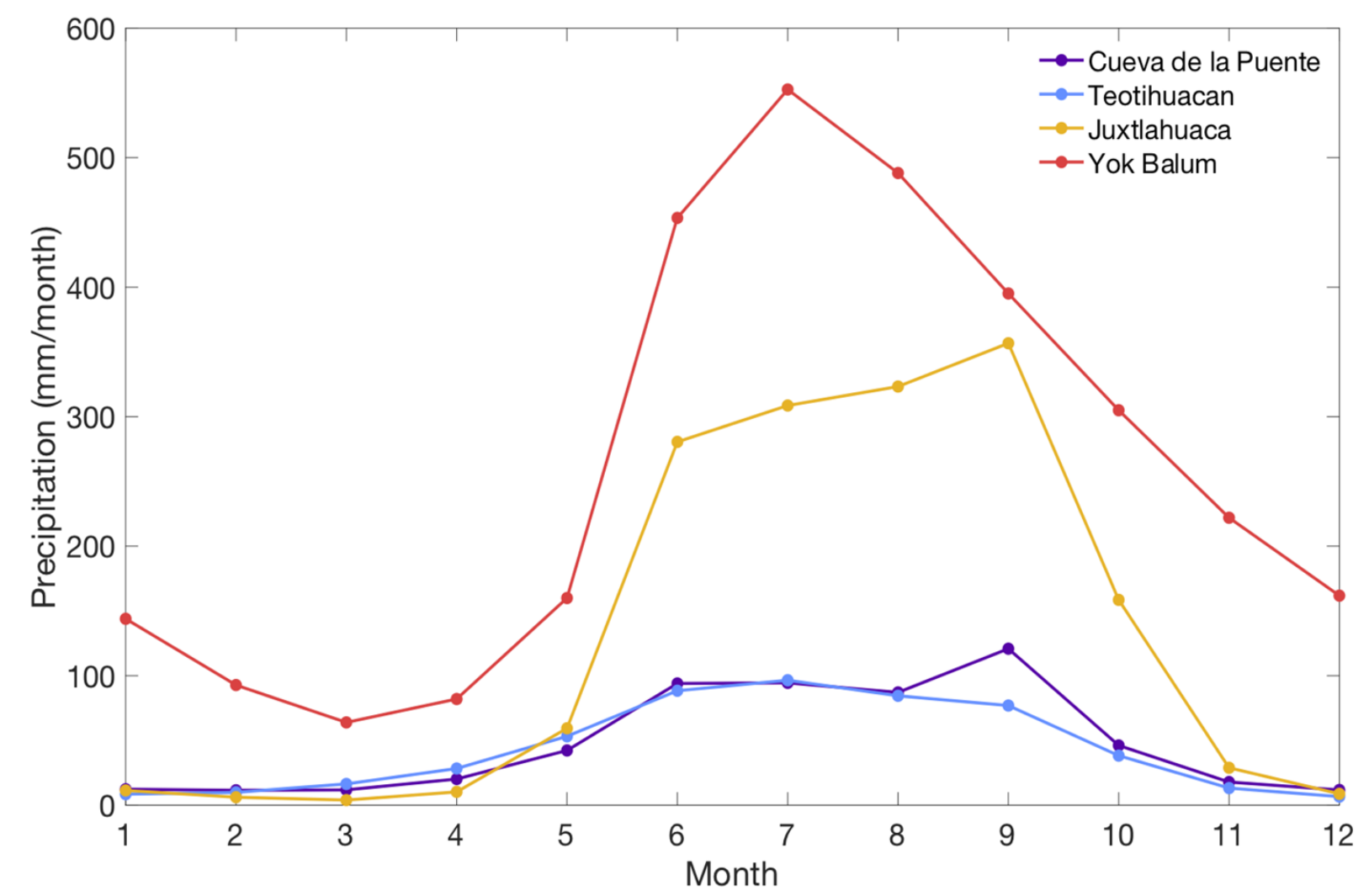

Figure 3. Climatology for grid points closest to Cueva de la Puente (this study), Juxtlahuaca (Lachniet et al., 2012, 2017), and Yok Balum (Asmerom et al., 2020; Kennett et al., 2012) Caves, based on 1891 2016 GPCC V2018 0.5 x 0.5 gridded data (Schneider et al., 2014, 2015). Cueva de la Puente, the northernmost site, is also the driest, with precipitation amount most similar to Teotihuacan, but all sites have a summer wet season. 

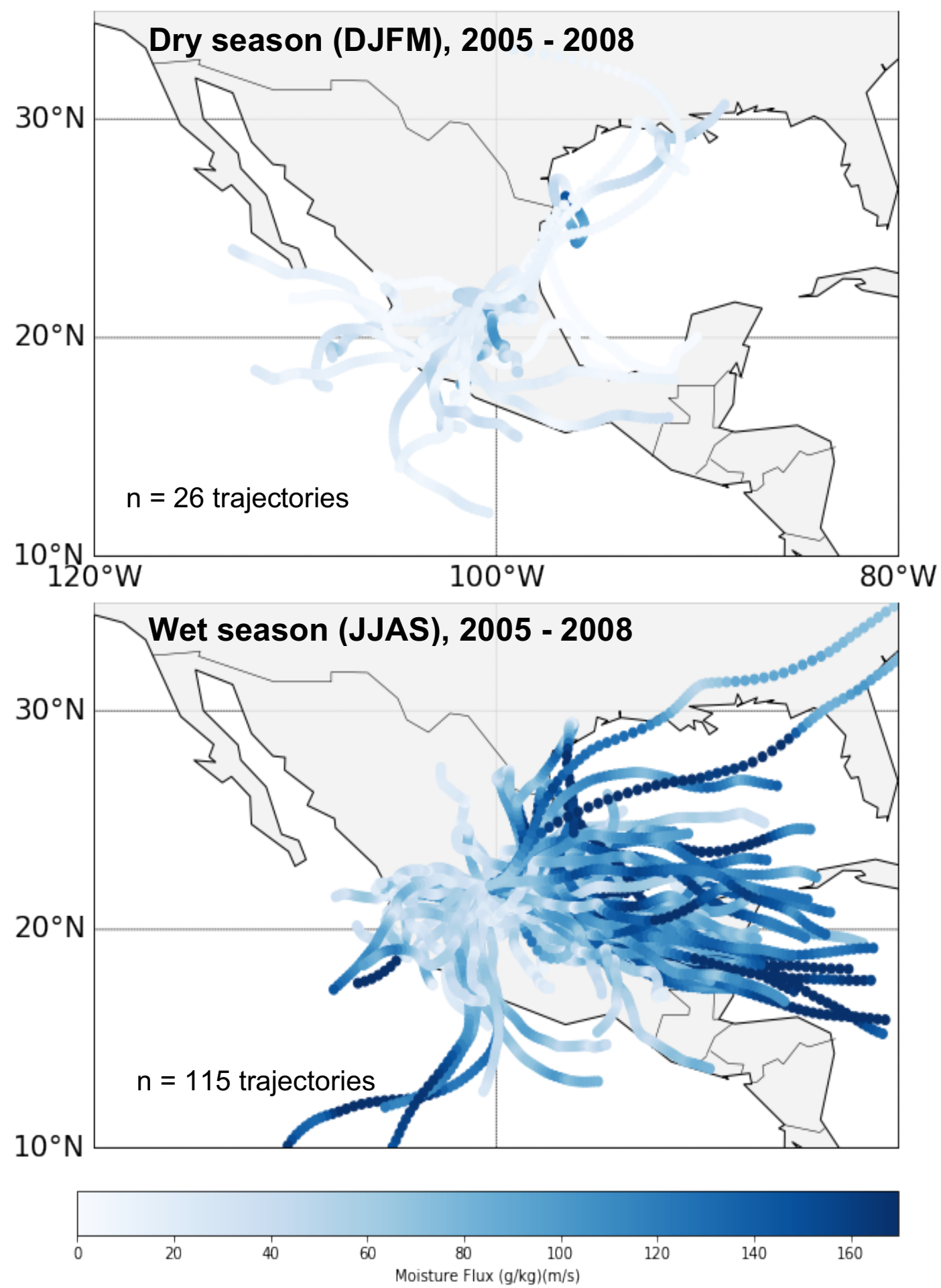

Figure 4. Rain-bearing moisture back-trajectories for dry season (DJFM, top) and wet season (JJAS, bottom) for Cueva de la Puente, analyzed with HYSPLIT (Stein et al., 2015) and PySPLIT (Warner, 2018) software. These trajectories show that the Caribbean Sea is the main source of moisture to CP, and that the vast majority of rain falls in the summer. Calculated with GDAS 0.5-degree meteorological data. See Appendix Figure A1 for trajectories in southern Mexico and Belize. 


\subsection{U-Series dating}

$\mathrm{U} / \mathrm{Th}$ analysis yielded tight age controls on the majority of the stalagmite, with uncertainty $<20$ years for 13 of 14 dates $( \pm 2 \mathrm{SD})$ including one pair of replicates; the mean uncertainty was 13 years (Figure 5 ). The top date has the greatest uncertainty ( \pm 23 years) due to higher detrital Th - often referred to as a "dirty" sample; it is the most sensitive to the initial ${ }^{230} \mathrm{Th} /{ }^{232} \mathrm{Th}$ correction (Figure 5). We used $4.4 \pm 2.2$ for the initial correction, which maintained stratigraphic order and is the default correction. All future age-proxy plots use the median age model derived from the COPRA software (Breitenbach et at., 2012). CP2 started growing at $289 \pm 13$ years CE, and the sample stops at $976 \pm 29$ years CE. The top of CP2 appears to have cracked off and was missing upon collection (Figure 5). The growth rate averaged $0.58 \mathrm{~mm} /$ year, with a range of 0.08 $-3 \mathrm{~mm} /$ year; average resolution is 3.1 years per sample. The white sections have a faster growth rate than the translucent grey sections (Figure 5). It is possible that the lower grey section ( $\sim 200$ $\mathrm{mm}$ from top) had a lower growth rate than is captured in the current age model, which is significant because it is close to the collapse of Teotihuacan. An additional date from this section would be a valuable improvement on the age model.

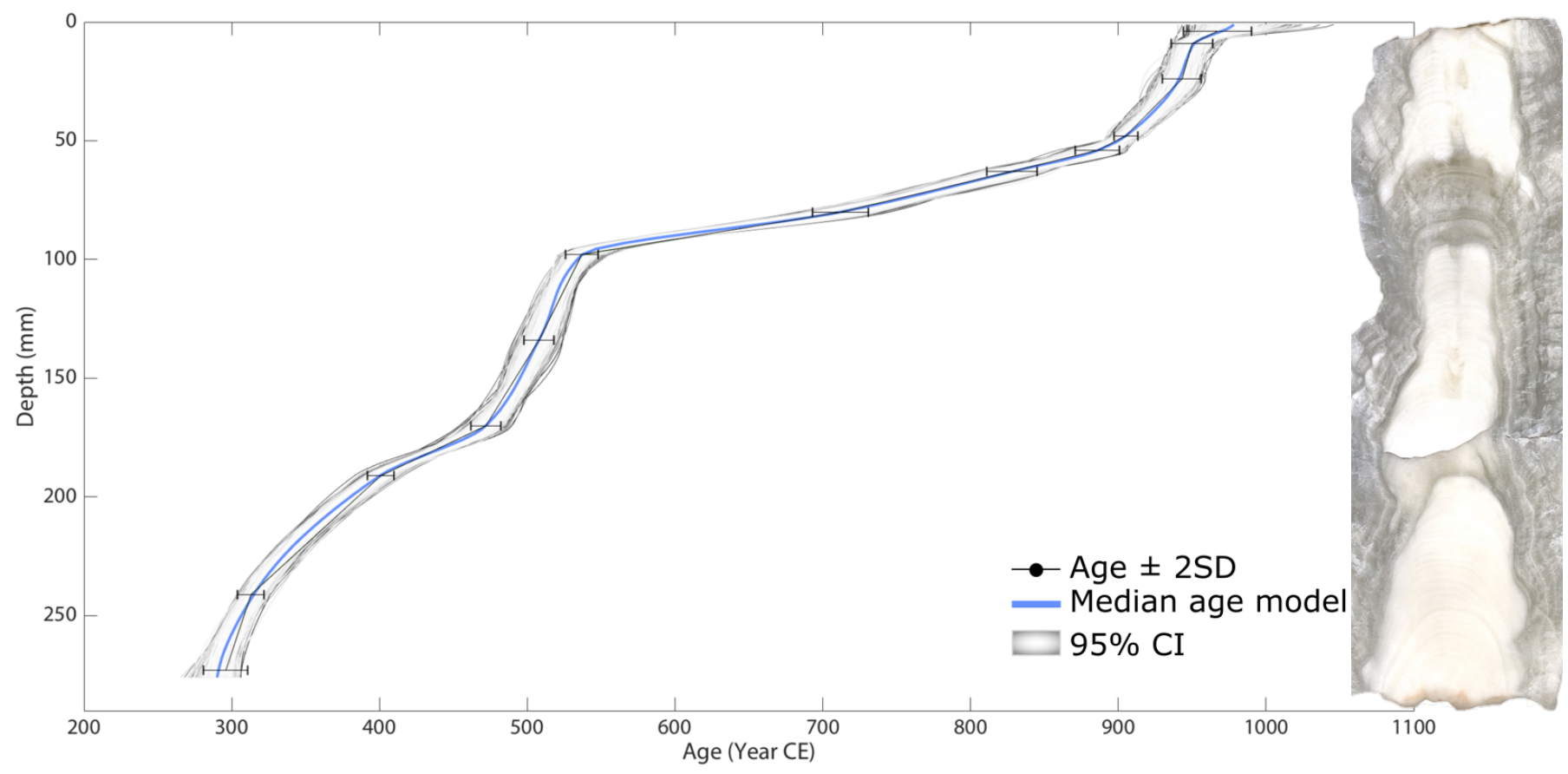

Figure 5. Age-depth model and scanned cross section for CP2, a stalagmite from San Luis Potosí, Mexico. The age model is based on 2000 Monte Carlo simulations with the COPRA algorithm (Breitenbach et at., 2012). Black horizontal show U-series dates \pm 2 standard deviations, while the blue line shows the median age model. Two replicate points were averaged to one date at $191 \mathrm{~mm}$ depth. Mean 2SD uncertainty is 13 years. 


\section{Year CE}
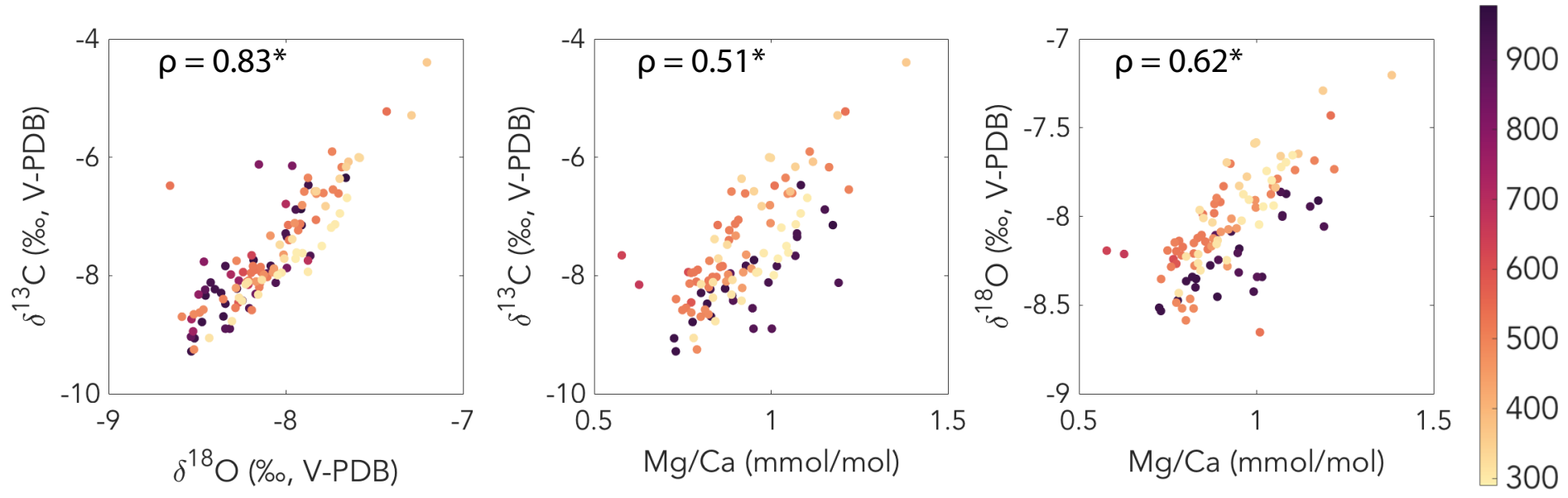

Figure 6. Spearman's rank correlation ( $\rho)$ for $\delta^{18} \mathrm{O}, \delta^{13} \mathrm{C}$, and $\mathrm{Mg} / \mathrm{Ca}$ in CP2. Asterisk $\left({ }^{*}\right)$ indicates statistical significance, based on $p$-value $<<0.001$.

\subsection{Stable isotopes and trace metal ratios}

Qualitatively, the $\delta^{18} \mathrm{O}$ and $\delta^{13} \mathrm{C}$ records are remarkably similar in shape, with several peaks occurring synchronously in both proxies (Figure 7 ). Mean $\delta^{18} \mathrm{O}$ was $-8.06 \pm 0.05 \% 0( \pm 2 \mathrm{SE}$ ), with a maximum of $-7.20 \%$ and a minimum of $-8.66 \%$; mean $\delta^{13} \mathrm{C}$ was $-7.59 \pm 0.08 \%$ ( $\left.\pm 2 \mathrm{SE}\right)$, ranging from $-4.40 \%$ to $-9.28 \%$. Maximum $\delta^{13} \mathrm{C}$ and $\delta^{18} \mathrm{O}$ both occurred at $358 \pm 8 \mathrm{CE}$ (Figure 7).

Mean $\mathrm{Mg} / \mathrm{Ca}$ was $0.87 \pm 0.01 \mathrm{mmol} / \mathrm{mol}( \pm 2 \mathrm{SE})$, with a minimum of $0.58 \mathrm{mmol} / \mathrm{mol}$ at $405 \pm 9 \mathrm{CE}$ and a maximum of $1.43 \mathrm{mmol} / \mathrm{mol}$ at $566 \pm 11 \mathrm{CE}$. Although the maximum $\mathrm{Mg} / \mathrm{Ca}$ value does not occur synchronously with maximum $\delta^{18} \mathrm{O}$ and $\delta^{13} \mathrm{C}$, there is a local maximum at the same time $(358 \pm 8 \mathrm{CE})$.

Mean $\mathrm{Sr} / \mathrm{Ca}$ was $0.102 \pm 0.0018 \mathrm{mmol} / \mathrm{mol}( \pm 2 \mathrm{SE})$, with a range of 0.054 to 0.16 $\mathrm{mmol} / \mathrm{mol}$. However, given its anticorrelation with $\mathrm{Mg} / \mathrm{Ca}$ in timeseries (Spearman's $\rho=-0.68$ ) and that it has the opposite relationship with $\mathrm{Mg} / \mathrm{Ca}$ as would be expected from prior calcite precipitation, we are excluding the $\mathrm{Sr} / \mathrm{Ca}$ from further analyses (Appendix Figure A2).

There is a statistically significant rank correlation between $\delta^{18} \mathrm{O}, \delta^{13} \mathrm{C}$, and $\mathrm{Mg} / \mathrm{Ca}$ in $\mathrm{CP} 2$ (Spearman's correlation, p-value $<<0.001$ ) (Figure 6). Trace element data resolution is higher than that of the stable isotopes $(\mathrm{Mg} / \mathrm{Ca} \mathrm{n}=209$, stable isotope $\mathrm{n}=121)$, so the stable isotopes were resampled to the same resolution for this correlation test. Shared trace element and stable isotope at identical depths $(\mathrm{n}=105)$ yielded higher correlations $\left(\delta^{18} \mathrm{O}\right.$ and $\delta^{13} \mathrm{C} \rho=0.88, \mathrm{Mg} / \mathrm{Ca}$ 
and $\delta^{13} \mathrm{C} \rho=0.72, \mathrm{Mg} / \mathrm{Ca}$ and $\delta^{18} \mathrm{O} \rho=0.70$, all $\mathrm{p}$-values $<<0.001$, which shows that that correlation coefficients were not artificially inflated by resampling. There was no significant correlation between growth rate and geochemical proxies. Coherence between $\mathrm{Mg} / \mathrm{Ca}, \delta^{18} \mathrm{O}$, and $\delta^{13} \mathrm{C}$ demonstrates that $\mathrm{Mg} / \mathrm{Ca}$ and stable isotopes can be used in concert as hydroclimate records from this region.
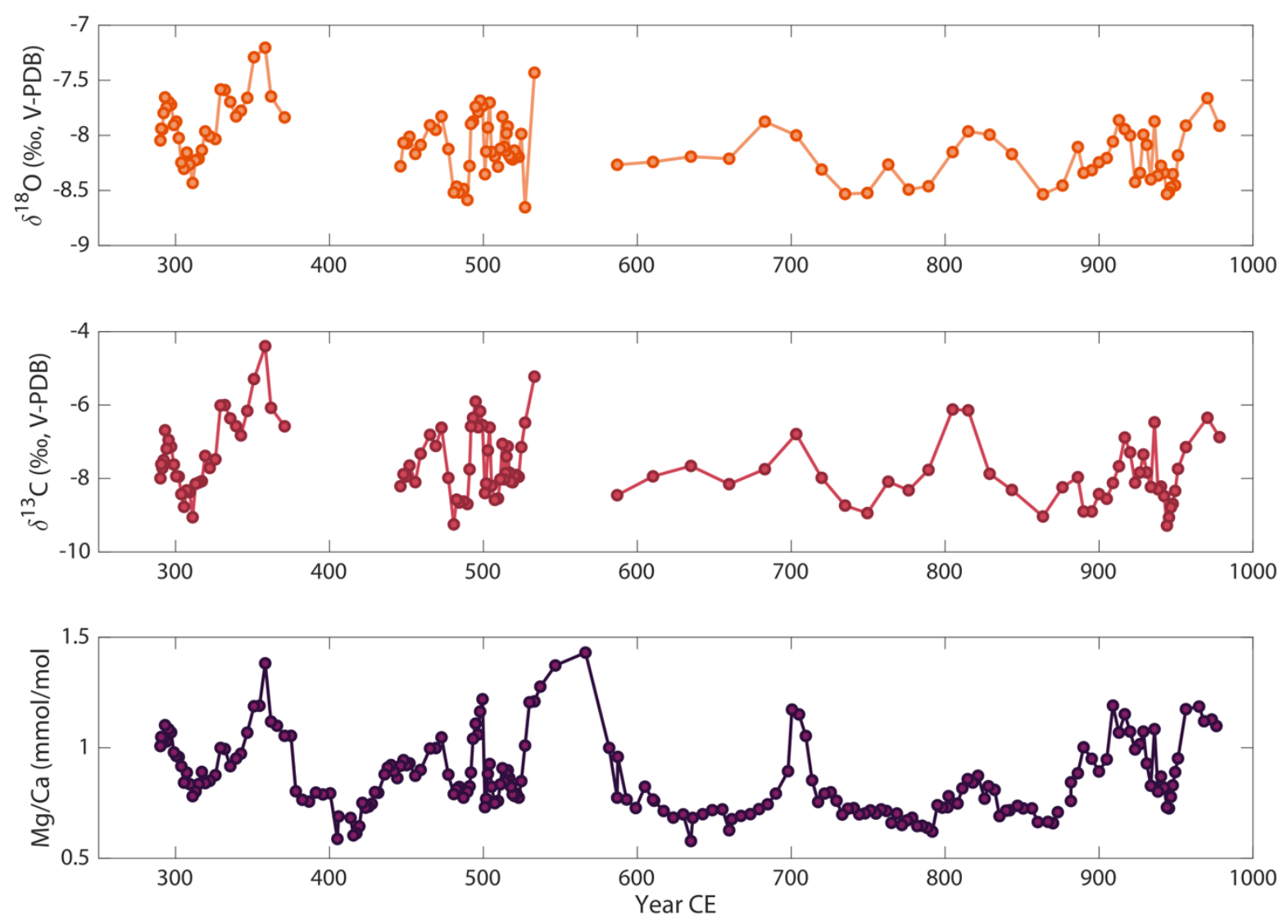

Figure 7. Stable isotope $\left(\delta^{18} \mathrm{O}\right.$ and $\left.\delta^{13} \mathrm{C}\right)$ and $\mathrm{Mg} / \mathrm{Ca}$ ratios in $\mathrm{CP} 2$, a Common Era stalagmite from $\mathrm{NE}$ Mexico.

Several peaks stand out as major ratio increases (drying) in all three proxies, such as those at $293 \pm 10,358 \pm 8$, and $566 \pm 11 \mathrm{CE}$. There are also several smaller increases between 700 and $1200 \mathrm{CE}$ (i.e. $701 \pm 19,815 \pm 18,915 \pm 9$ ). The peak at $358 \pm 8 \mathrm{CE}$ is most extreme, in that it has the maximum $\delta^{18} \mathrm{O}$ and $\delta^{13} \mathrm{C}$ ratios and is $>2 \mathrm{SD}$ over the mean proxy values. In total, there were 8 instances of $\mathrm{Mg} / \mathrm{Ca}$ increasing at least 1SD over the mean (drying) and 4 instances of decreases 1SD less than the mean, interpreted as wet periods (Figures 7 and 8). These anomalies 
were only counted if at least two consecutive data points were outside the \pm 1 SD envelope, in order to avoid over-interpretation of a single point.

In addition, it is notable that the dry period peaking at $566 \pm 11 \mathrm{CE}$ began around $523 \pm 8$ CE, well before to the massive Tierra Blanca Joven Ilopango eruption at 540 CE (Dull et al., 2019). Therefore, we can rule out the Ilopango eruption as the initial cause for this drought, though it may have played a role in prolonging it.

We acknowledge gaps in sampling of stable isotopes, as powders have not yet been analyzed around a break in the stalagmite between 375 and $450 \mathrm{CE}$ (Figure 7). This portion of the stalagmite is also grey, meaning that it may have a slower growth rate. There is also varying sampling resolution throughout the stalagmite, but we plan to increase the resolution and coverage. The $\mathrm{Mg} / \mathrm{Ca}$ data that we do have, however, shows that there were no major changes in proxy values that were not captured at lower resolution; in other words, the stable isotope data aren't "missing" any significant variations in $\mathrm{Mg} / \mathrm{Ca}$ (Figure 7). That said, it would be helpful to have higher resolution data covering 525-600 CE and 800-980 CE, given the dramatic increase in values and the importance of the MCA, respectively. 

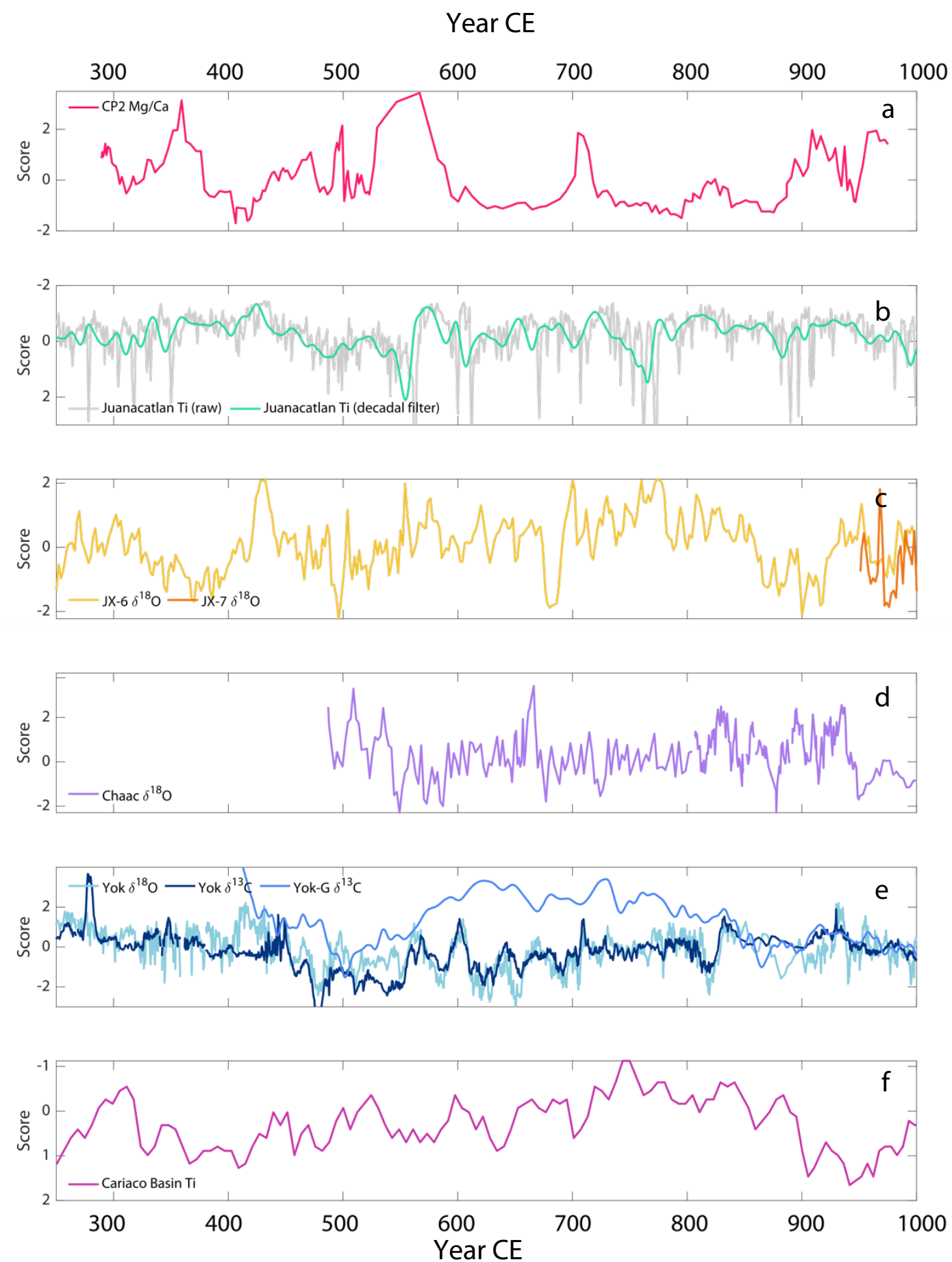

Figure 8. Z-scores of a) CP2 Mg/Ca (this study) with previously published records; higher values indicate drier conditions on each panel. b) Juanacatlan titanium, raw and with a 10-year Butterworth filter (Davies et al., 2018) c) Juxtlahuaca (JX) 6 and 7 (Lachniet et al., 2012, 2017), d) Chaac (MedinaElizalde, Polanco-Martínez, et al., 2016), e) Yok-I (Kennett et al., 2012) and Yok-G (Asmerom et al., 2020) from Yok Balum Cave, Belize, f) Cariaco Basin titanium (Haug et al., 2001). Note the reversed y-axis for Juanacatlan and Cariaco Basin, as higher Ti scores are interpreted as more precipitation (Haug et al., 2001; Davies et al., 2018). See Appendix for figure with \pm 1 SD vertical bars. 


\subsection{Mexican Early Classic Period (300-550 CE)}

Qualitatively, the Early Classic Period appears more variable than the subsequent centuries. The CP2 record captured two drying events during the first part of the Early Classic, peaking at $293 \pm 10$ and $358 \pm 8 \mathrm{CE}$ (Figures 7 and 8). Based on the modern relationship between monthly $\delta^{18} \mathrm{O}_{\text {precip }}$ and rainfall amount, we estimate that $\mathrm{CP} 2 \delta^{18} \mathrm{O}$ recorded a maximum of a $37 \%$ decrease in rainfall amount, in comparison to mean $\delta^{18} \mathrm{O}$ from the full record, during the dry event at 358 \pm 8 . Although the two dry periods are not reflected in other regional records, the coherence between all three proxies in CP2 (Figure 7) is suggestive that these periods of elevated values were driven by shifts in hydroclimate.

After the $358 \pm 8 \mathrm{CE}$ dry event, the stalagmite transitioned to a much slower growth rate, which could indicate further drying; in $\mathrm{Mg} / \mathrm{Ca}$, however, there is a decrease to significantly lower (wetter) values after the peak. Higher resolution stable isotope measurements during this period will help clarify the climate state at $\mathrm{CP}$ after the drought at $358 \pm 8 \mathrm{CE}$ and ensure that the change in growth rate was not the primary driver of $\mathrm{Mg} / \mathrm{Ca}$ change. Nonetheless, the $\mathrm{Mg} / \mathrm{Ca}$ data indicate that there was a multi-year-long wet period in the early $5^{\text {th }}$ century.

The $\mathrm{CP} 2$ record shows two significant increases in all proxies (interpreted as drying) at the end of the Early Classic. The first is a short event from 490 to $501 \mathrm{CE}( \pm 9)$ with values greater than one standard deviation over the mean, but not as severe as subsequent droughts. The second is much longer: the increase started at $523 \pm 8 \mathrm{CE}$ and it continued into the Epiclassic Period.

\subsection{Mexican Epiclassic Period (550-850 CE)}

All CP2 proxies reached a local maximum at $566 \pm 11 \mathrm{CE}$, followed by a return to mean values at $587 \pm 12 \mathrm{CE}$. However, we note that this period is has low sample resolution, with an average of 6 years per sample in $\mathrm{Mg} / \mathrm{Ca}$. There is a single low data point just before the peak in $\delta^{18} \mathrm{O}$, which would indicate an anomalously wet period, but this could be an outlier because the other two proxies don't reproduce the dramatic decrease. As with the Early Classic, further highresolution stable isotope data will be useful to identify whether the single data point is accurate and improve our understanding of the timing of the $566 \pm 11 \mathrm{CE}$ drought.

There was an increase in $\mathrm{Mg} / \mathrm{Ca}$ peaking at $701 \pm 19 \mathrm{CE}$ (spanning 691-718 CE, which means that the duration of the drought was longer than the uncertainty of \pm 19 years). There were simultaneous increases in the stable isotopes, but they did not rise above the +1SD cutoff (Figure 7). Juxtlahuaca (Lachniet et al., 2012) and Yok-I (Kennett et al., 2012) both show 
increased values at a similar time and with a similar duration, which suggests that this short, moderate drought may have had a vast spatial extent. This event needs further study to better characterize the timing and understand potential human-environmental connections. Lachniet et al. (2012) found a long-term drought that culminated much later, in $770 \mathrm{CE}$, which is not replicated in $\mathrm{CP} 2$.

\subsection{Medieval Climate Anomaly in CP2 (850-976 CE)}

The CP2 sample recorded part of the MCA, ending at $976 \pm 29 \mathrm{CE}$, so we define the MCA as 850-976 CE in subsequent sections. We checked the mean values of geochemical proxies from 850 to $976 \mathrm{CE}$ against the overall mean to test for a shifted mean state during the portion of the MCA captured in CP2, using p-value $<0.05$ as the cutoff for significance. Both $\delta^{18} \mathrm{O}$ and $\delta^{13} \mathrm{C}$ were significantly lower (wetter) than the overall average (one-sample Z-test; $\delta^{18} \mathrm{O}$ p-value $=0.016 ; \delta^{13} \mathrm{C}$-value $\left.=0.019\right)$; these results were confirmed with a Mann-Whitney Utest, which demonstrated that the medians were also significantly lower during the MCA (pvalue $=0.03$ ). $\mathrm{Mg} / \mathrm{Ca}$ was not significantly different (one-sample Z-test; $\mathrm{Mg} / \mathrm{Ca} \mathrm{p}$-value = 0.057). The results from the stable isotopes contrast with drying reported in southern Mexico during the MCA. Based on other data showing coherent drying in Mesoamerica around $1000 \mathrm{CE}$ (Kennett et al., 2012), it's possible that drying started later on, after CP2 had stopped growing. That said, two significant ( $>1 \mathrm{SD}$ increase) $\mathrm{Mg} / \mathrm{Ca}$ peaks occurred between 850 and 1000 (Figure $8)$, which could indicate dry events, even if the mean state was wetter.

\subsection{Spatial and Spectral Analyses}

Although it is useful to examine the proxy records directly to better understand individual time periods, such as those highlighted in the previous sections, different types of analyses are more useful for quantitative testing of the potential precipitation dipole.

Wavelet analysis of normalized, 20-year low-pass Butterworth filtered data shows a multidecadal (64-128 years) period in $\mathrm{Mg} / \mathrm{Ca}$ until $675 \mathrm{CE}$, after which that period is no longer significant (Figure 9). Stable isotopes do not show significant periodicity. Before Butterworth filtering, there is a notable lack of periodicity at 4-10 years in $\mathrm{Mg} / \mathrm{Ca}$, which is the only proxy with high enough sampling resolution to resolve periodicity under 20 years. Less than half of the stable isotope record is at a high enough resolution to detect ENSO periodicity. As a preliminary result, it appears that there is no significant or persistent ENSO signal in the CP2 record, but 
once we have high resolution data for $\delta^{18} \mathrm{O}$ and $\delta^{13} \mathrm{C}$ (less than 4 years per sample), we will rerun the wavelet analysis.
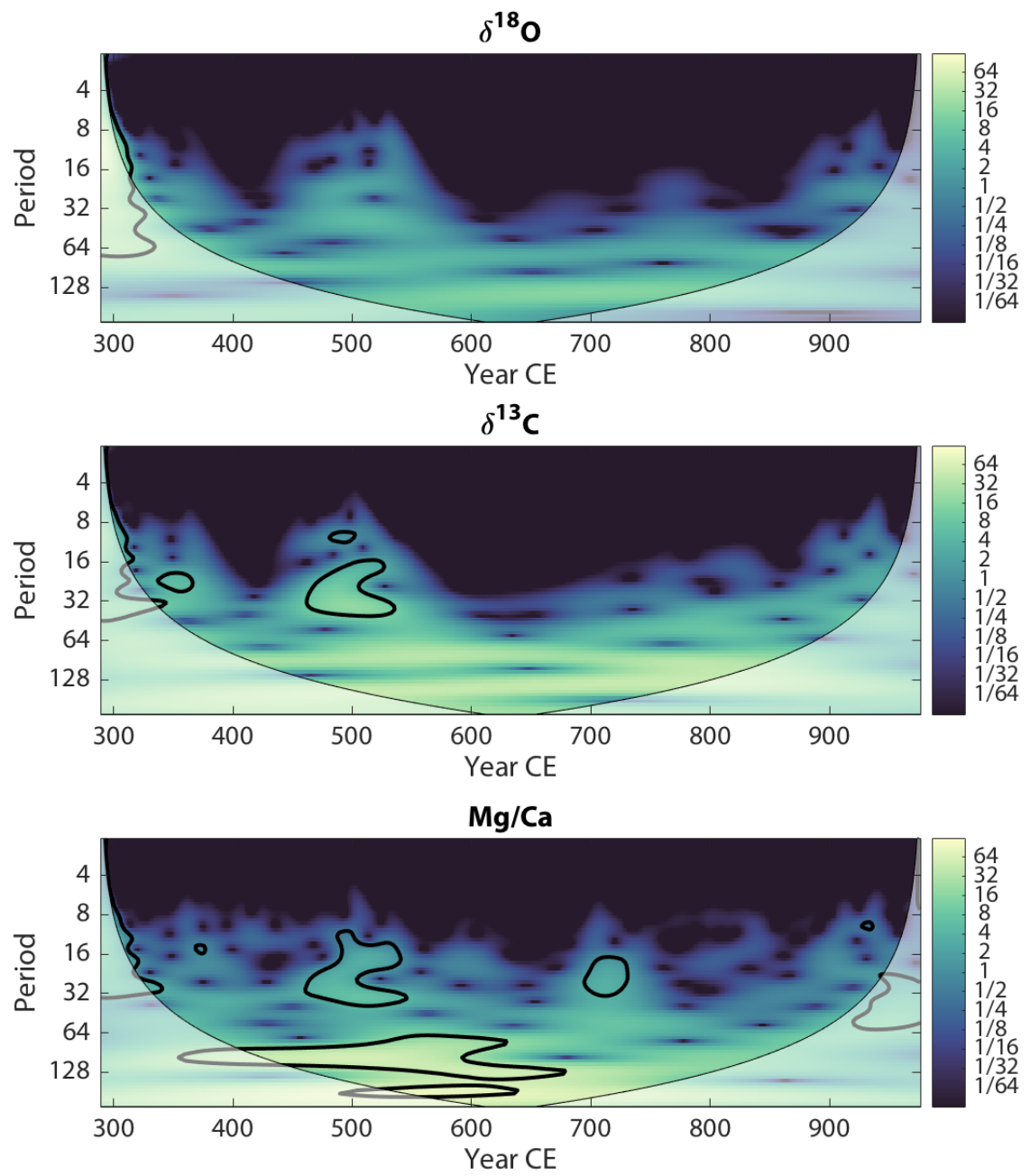

Figure 9. Wavelet analysis for $\mathrm{CP} 2$ stable isotopes and $\mathrm{Mg} / \mathrm{Ca}$, all analyzed after normalizing and applying a 20-year low-pass Butterworth filter to account for sampling frequency; black lines denote statistically significant periods. Before $\sim 675 \mathrm{CE}$, there is a multidecadal period (64 to 128 years) in $\mathrm{Mg} / \mathrm{Ca}$. The other proxies do not show any long-term significant trends, which may be due to resolution.

As noted previously, coherence across all three geochemical proxies in CP2 suggests that they are recording responses to the same broad forcing, presumed to be hydrological changes. Because $\delta^{18} \mathrm{O}$ and $\mathrm{Mg} / \mathrm{Ca}$ are highly correlated, and $\mathrm{Mg} / \mathrm{Ca}$ has better temporal resolution and coverage, we used $\mathrm{Mg} / \mathrm{Ca}$ as the main basis for our empirical orthogonal functions (EOF) analyses. 
Age-model-enabled EOF analysis demonstrated, in a quantitative way, the broad pattern noted throughout this study: CP (and therefore, NE Mexico) behaves differently from southern Mexico, Belize, and the Cariaco Basin (Figure 10). More specifically, we note that CP is positively correlated with mode 1 , which highlights a slow drying from $\sim 500 \mathrm{CE}$ to $1000 \mathrm{CE}$ (Figure 10) and explained $41 \%$ of the variance seen in the records. The other 4 orthogonal modes of variability (not shown) were not statistically significant based on the scree slope test (Appendix). The Cariaco Basin and Yok Balum sites are highly anticorrelated with mode 1 (Figure 10); both sites maintain the same sign of correlation within the 95\% CI of their age models. Juxtlahuaca and Juanacatlan, however, are only slightly correlated with mode 1 - they have the lowest weights and the sign of correlation flips for the low end of the $95 \% \mathrm{CI}$. Significantly, the EOF analysis demonstrated that the spatial correlation patterns from the first millennium of the Common Era (Figure 10) are remarkably similar to the modern correlation between summer precipitation at $\mathrm{CP}$ and the rest of Mesoamerica (Figure 1B). 

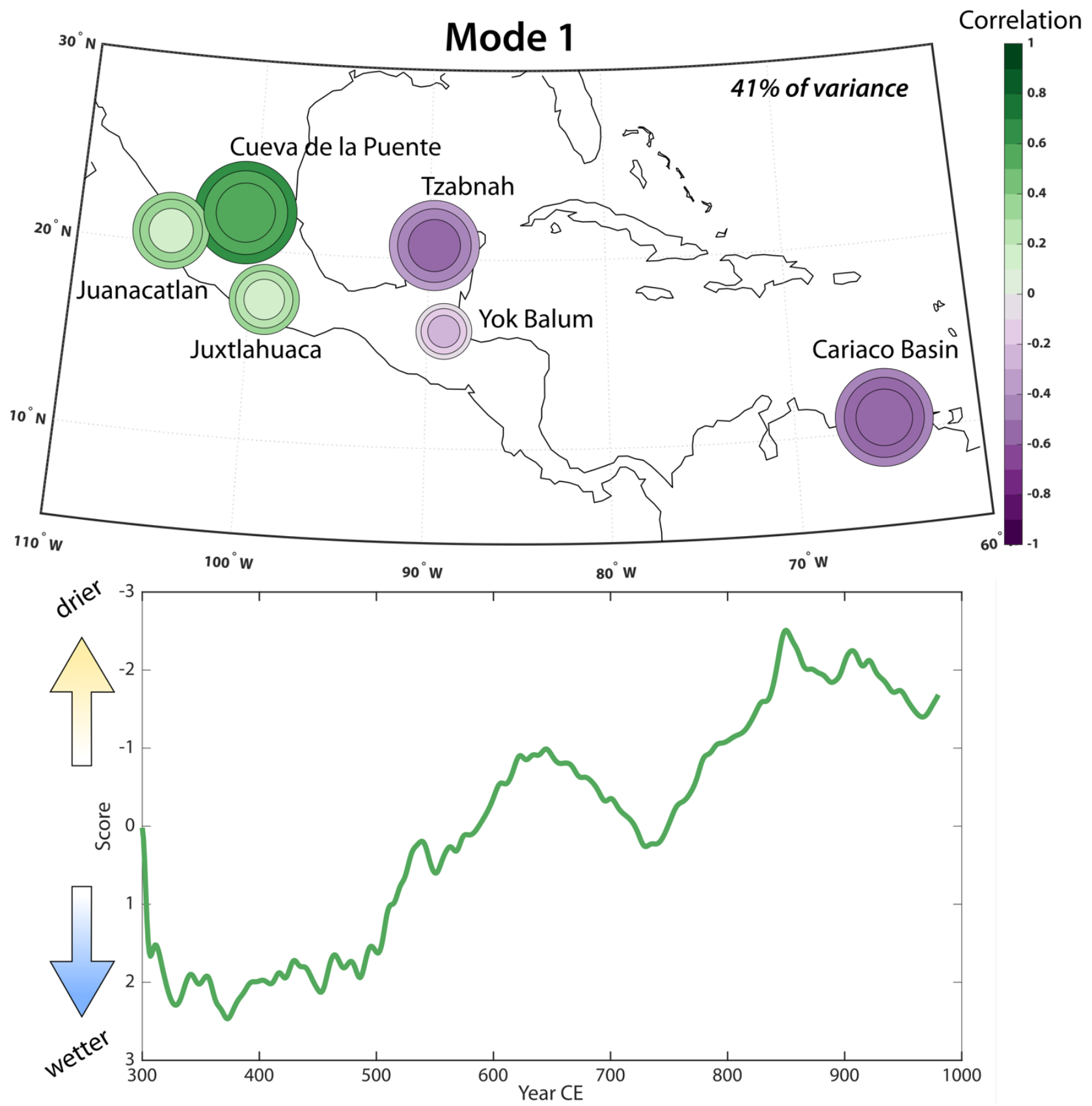

Figure 10. Top: Empirical orthogonal function (EOF) analysis of CP2 Mg/Ca from Cueva de la Puente (this study) with JX-6 $\delta^{18} \mathrm{O}$ from Juxtlahuaca (Lachniet et al., 2012, 2017), Juanacatlan Ti (Davies et al., 2018), YOK-I $\delta^{18}$ O from Yok Balum (Kennett et al., 2012), Chaac $\delta^{18} \mathrm{O}$ from Tzabnah (Medina-Elizalde \& Rohling, 2012), and Cariaco Basin Ti (Haug et al., 2001). The inner circle of each target indicates the correlation at the low $95 \% \mathrm{Cl}$ age model; the middle circle indicates the correlation with the median age model, and the outer circle shows the high $95 \% \mathrm{Cl}$. Larger target shapes indicate higher loading at that site, and color denotes the correlation coefficient. Figure and analysis based on code from Tripti Bhattacharya (pers. comm). Bottom: Statistically significant EOF mode 1 ( $41 \%$ of variance). Y-axis is reversed to match convention of other figures; negative scores correspond to lower precipitation/moisture. 


\section{Discussion}

Across all three geochemical proxies, the $\mathrm{CP} 2$ record shows a fairly stable mean state punctuated by decadal-scale droughts/dry events, which occurred more commonly than anomalously wet events. On longer scales (centuries), we note that moisture in NE Mexico and the Yucatán and Cariaco Basin are anticorrelated, which supports the existence of a dipolar precipitation pattern. Examining at the records at a decadal scale highlights the spatial complexity of Mexican precipitation.

\subsection{Mexican Early Classic Period (300-550 CE)}

Results from EOF mode 1 indicate that, in northeast Mexico, 300-500 CE was substantially wetter than the next 500 years. If we assume that the climate mean state and drought events were similar at Teotihuacan, EOF mode 1 further confirms the idea that there was plenty of water in the city in those centuries. Given how much the city grew from 100 to $500 \mathrm{CE}$, with extensive drought preparation and water management strategies, we suggest that the decadal-scale droughts before $500 \mathrm{CE}$ did not pose a significant pressure or threat on the Teotihuacan Valley. Further archaeological investigation is required to confirm or refute this hypothesis.

It is also notable that the NAO index was positive for most of the Early Classic, but it shifted to neutral or negative at $501 \pm 29 \mathrm{CE}$ (Drake, 2017; Olsen et al., 2012) and that there was an anomalously warm period centered at 395 CE (PAGES 2k Consortium et al., 2013). Furthermore, Lachniet et al. $(2012,2017)$ indicates that 300 to 400 was a pluvial (high precipitation) period at Juxtlahuaca, showing a wet period synchronous with that of the CP2 record around 400 .

Because reconstructed NAO was positive from 300 to $500 \mathrm{CE}$ and NAO is negatively correlated with rainfall in most of Mexico (Bhattacharya et al., 2017; Giannini et al., 2000), we suggest that EOF mode 1 does not reflect NAO-based forcing, as it has the opposite response to that expected from NAO. Instead, it could reflect AMV, PDO, or another ocean-atmosphere feedback. Finally, because previous research has suggested that PDO is not a major driver of Atlantic Mexican precipitation (Bhattacharya et al., 2017), the process of elimination suggests that EOF mode 1 is primarily reflective of AMV. Analysis of subsequent time periods (Sections 4.3 and 4.4) will help to further support or refute this idea. 


\subsection{Mexican Epiclassic Period (550-800 CE)}

The climate state between $\sim 550$ and $800 \mathrm{CE}$ is of particular interest because of the archaeological record at Teotihuacan, which indicates dramatic decrease in population and rapid abandonment of agriculture (Acuna-Soto et al., 2005; Lachniet et al., 2012, 2017; Mejía Ramón \& Johnson, 2019; Park et al., 2019). Although there is some debate about the specific timing and cause of the population decline, the majority of archaeological studies land somewhere between $550 \mathrm{CE}$ and $650 \mathrm{CE}$, with many recent studies converging on the earlier end of that estimate (Acuna-Soto et al., 2005; Cowgill, 2013; De Tapia, 2012; Mejía Ramón \& Johnson, 2019). In any case, they tend to agree that Teotihuacan reached its peak population in the Early Classic and that there were major shifts after $550 \mathrm{CE}$.

In the instrumental era, we demonstrate that Teotihuacan receives an almost identical amount of precipitation as Cueva de la Puente, and has very similar climatology or seasonality. Although paleoclimate investigations at sites in southern Mexico are valuable in many other ways, we suggest that they are not the best sites for investigation of climate-driven social change at Teotihuacan, despite their modern correlation. In addition, rather than looking for one specific drought, or identifying individual events, climate scientists and archaeologists can move toward considering the long-term climate state under which complex societies developed. EOF mode 1 demonstrates that NE Mexican climate was relatively wet until $500 \mathrm{CE}$, after which moisture declined. Though Juxtlahuaca and Juanacatlan are weakly correlated with mode 1, they are still slightly positively weighted. Therefore, we argue that EOF mode 1 is representative of the northern and central Mexican precipitation pattern, which reflects Caribbean-derived summer moisture. Although decadal-scale droughts were a persistent feature of this period, it appears that the relatively wet background climate state and water management practices at Teotihuacan allowed the city to effectively weather those dry periods before $500 \mathrm{CE}$. A trend toward drying that started at $500 \mathrm{CE}$ (EOF mode 1) and a subsequent significant drought event (peaking at 566 $\pm 11 \mathrm{CE}$ ) occurred close to the depopulation, which suggests that hydroclimate may have been a factor in the societal changes. Furthermore, after the collapse of the state around $550 \mathrm{CE}$, people in the Teotihuacan Valley were unable to rebound, based on evidence that agriculture collapsed entirely and population stayed significantly lower than peak levels for centuries (Mejía Ramón \& Johnson, 2019). This occurred despite a relatively wet and stable period at CP2, which requires more analysis from archaeologists. It is possible that it was more difficult for the population to 
rebound or bring back extensive agriculture under significantly different conditions than those from 100-500 CE.

Finally, under the assumption that Juxtlahuaca precipitation is primarily controlled by NAO and PDO/ENSO (Lachniet et al., 2012, 2017), rather than AMV, and the lack of extreme, multidecadal droughts recorded in that stalagmite from 550-700 CE, we suggest that the drought peaking at $566 \pm 11 \mathrm{CE}$ in CP2 was primarily driven by AMV, or an Atlantic SST warm event. This interpretation would explain why the decades-long drought seen in CP2 was not recorded at Juxtlahuaca (Lachniet et al., 2012). We also note that the NAO index rapidly increased from 550 to $750 \mathrm{CE}$ (Appendix), at which point Juxtlahuaca did record a drought, so perhaps increasingly positive NAO overlapped with a peak in AMV at $550 \mathrm{CE}$ to create the multidecadal drought seen in $\mathrm{CP} 2$.

\subsection{Medieval Climate Anomaly in CP2 (850-976 CE)}

The Medieval Climate Anomaly is an important time period because it is marked by mega-droughts in southwest North America, but we have no data to assess responses in NE Mexico. NAO reconstructions from the end of the MCA suggest that there was a persistent positive NAO throughout the MCA (Trouet et al., 2009). Positive NAO has been linked to decreased precipitation in northern Mexico (Bhattacharya et al., 2017; Giannini et al., 2000), so as in the Early Classic Period, a persistently positive NAO would be expected to yield dry MCA conditions.

Instead, CP2 shows slightly wetter median proxy values during the MCA. However, we find that the median proxy values are not the most informative statistic; this is consistent with the findings in Lachniet et al. (2017). Instead, we examine the timing and approximate length of drying events during the MCA. There are two major dry periods captured in CP2 between 800 and 1000, which may correspond to the Terminal Classic droughts recorded in Chaac or at Yok Balum (Kennett et al., 2012; Medina-Elizalde, Polanco-Martínez, et al., 2016), but are not synchronous with drying in JX-6 and JX-7 (Lachniet et al., 2012, 2017).

These results show that the MCA did not occur as a distinct shift to wetter or drier hydroclimate mean state in northern Mexico; instead, it is reflected with increased drought durations. Though Kennett et al. (2012) suggest that the $\sim 100$-year-long dry period in Yok Balum during the MCA is a mean-state shift that is equivalent to that observed in Europe, we argue that it is actually further evidence of extended droughts, as that stalagmite shows a 
temporary increase in proxy data that later return to baseline values. As further evidence that the MCA was a period of extended droughts, Chaac recorded one of the longest and most dramatic droughts of its whole growth period centered at 928 CE (Medina-Elizalde \& Rohling, 2012). Finally, Montezuma bald cypress tree ring record showed a drought from 897 to $922 \mathrm{CE}$ (Stahle et al., 2011), which may be the same drought seen in CP2 at the same time.

\subsection{Periodicity and long-term trends}

Results from the wavelet analysis showed that there was no prominent ENSO signal $(<10$ years per cycle), unlike the Juxtlahuaca records (Lachniet et al., 2012, 2017), the Park et al. (2019) sediment record, or the Chaac record (Medina-Elizalde, Polanco-Martínez, et al., 2016; Medina-Elizalde \& Rohling, 2012). In order to ensure that the lack of periodicity is not a result

of sampling frequency, however, we will proceed with higher resolution sampling throughout the record. On a preliminary basis, these results suggest that other climate forcings were more significant during the CP2 growth period, or that the effects of ENSO were very weak at this site. Trajectory analysis that showed that the majority of summer precipitation is coming from the Atlantic and the Caribbean, not the Pacific, for CP; in contrast, other sites have more moisture sourced from the Pacific (Appendix). Therefore, we argue that ENSO was not a major influence on northern Mexican precipitation during the first millennium of the Common Era.

Instead, $\mathrm{CP} 2 \mathrm{Mg} / \mathrm{Ca}$ shows significant periods at 64 to 128 years per cycle. Based on current understanding of AMV, including a lack of consensus on the periodicity, it is plausible that this is an expression of hydroclimatic change driven by shifting Atlantic SST (AMV).

The most prominent result from the EOF analysis was opposite multi-centennial trends in NE Mexico and the Cariaco Basin, with NE Mexico gradually drying and the Cariaco Basin gradually receiving higher river discharge (increasing Ti accumulation) from 500 to $1000 \mathrm{CE}$. Using the Cariaco Basin record as an indicator of Atlantic ITCZ position, we would expect that increasing Ti accumulation in Cariaco Basin sediments means a northward-shifted ITCZ (Haug et al., 2001). This northward shift suggests a warmer North Atlantic relative to the South Atlantic, similar to the SST patterns associated with a positive phase of the AMV. EOF Mode 1, which indicates increasing precipitation at Cariaco from 500 to $1000 \mathrm{CE}$, would suggest a northward-moving ITCZ, and thus a trend toward more consistently warm North Atlantic SSTs. This does not match up with NH summer insolation, which show a modest downward trend, decreasing by $3 \mathrm{~W} / \mathrm{m}^{2}$ at the latitude of CP during the growth period of CP2 (Appendix) (Greene 
et al., 2019). Therefore, we rule out insolation as the main driver behind EOF Mode 1. Instead, we posit that EOF Mode 1 may be driven by internal ocean-atmosphere variability or by a longterm decrease in volcanic eruption frequency (Sigl et al., 2015). Strikingly, this multi-centennial trend toward a northward-shifted ITCZ (and warmer North Atlantic SSTs) produced dipolar patterns similar to those observed in modern correlations (Figure 2) and last millennium climate model simulations (Bhattacharya et al., 2017). In this framework, NE Mexico and Atlantic ITCZ position are connected because both respond to North Atlantic SST and NASH changes, but not because tropical rain belt precipitation directly impacts NE Mexico.

\section{Conclusions}

This study presents a new, high-resolution, precisely dated stalagmite from northern Mexico spanning $289 \pm 13$ to $976 \pm 29$ years CE; this is the first stalagmite record from the first millennium of the Common Era in northern Mexico. We show that $\mathrm{Mg} / \mathrm{Ca}$ and stable isotope ratios can be used as proxies of past hydrological change in this region. Using this record, we have demonstrated that there is regional variability in Mexican Common Era hydroclimate, remarkably consistent with modern correlation. More specifically, these results provide a test of the hypothesized (but previously untested) dipolar northern vs southern Mexican hydroclimate in the first millennium CE. The dominant mode of the new stalagmite record shows that northeast Mexican precipitation is anticorrelated with that of southern Mexico; in NE Mexico, this mode showed a relatively wet period from 300 to 500, followed by a drying trend until 1000 .

These data help provide new insights into human-environmental connections at Teotihuacan. We posit that the wet period from 300 to 500 CE may have helped support the Classic Period of development in the Teotihuacan Valley. The decades-long drought peaking at $566 \mathrm{CE}$ may have played a role in depopulation, currently estimated at $550 \mathrm{CE}$. Furthermore, the CP2 stalagmite record suggests that there were several decadal-scale droughts in the centuries following the collapse, which may have complicated recovery and a return to higher population levels.

The spatial variability in the Common Era suggests that paleoclimate studies need a more nuanced approach to discussing Mesoamerican hydroclimate; we shouldn't conclude that all of Central America or Mexico was dry, for example, based only on the Yucatán Peninsula; even central Mexico is different from NE Mexico. This is not to say that individual paleoclimate 
records are not useful for understanding nationwide or continent-wide climate shifts, especially on multi-centennial (or longer) time scales, but interpretations of these records must take into account the possibility of opposing responses in different parts of the country. Furthermore, we point out that the records vary widely from each other on decadal to centennial scales; this supports the need for more paleoclimate records from more of Mexico to refine our understanding of decadal-scale droughts.

Taking this finding one step further, we note that Mexican archives of past hydrology are often compared to or correlated with shifts in human civilization, no matter how far away the study site is from the archaeological site in question. The new hydroclimate record presented here might have important implications for the history of Teotihuacan and the lack of recovery after population decline, but we are wary of assuming greater spatial coherence than is warranted.

\subsection{Future Work}

While these data provide new insights into a previously under-studied region, there is still much more to do. First, we plan to analyze two more dates from the top of CP2 to refine the most uncertain point of the age-depth model. If these new dates have uncertainties similar to the rest of the dates in the stalagmite, they will reduce the uncertainty at least 5-fold. It's particularly important to refine that area because of the potential to further analyze the MCA at highresolution. In addition, we plan to obtain and analyze higher resolution stable isotope and $\mathrm{Mg} / \mathrm{Ca}$ data for the whole length of the CP2 stalagmite, especially filling in the gap after $400 \mathrm{CE}$. These additional data points will make our analyses more robust, as they will ensure that we have a clearer sense of when the peaks and troughs in the CP2 record occurred.

On a broader scale, this stalagmite is just one of a suite from northeast Mexico, including another one discussed in Chapter 3. Taken together, this suite of samples will advance paleoclimatologists' understanding of Mexican climate from 58ky BP to the present.

\section{Acknowledgements}

We acknowledge support from NSF grants AGS-1804512 and AGS-1806090. We also appreciate funding from the MIT EAPS Student Research Fund, the MIT MISTI Mexico program, and an NSF GRFP award (GSM). Initial work for this project was also supported by UC MEXUS-CONACYT Collaborative Grant from the University of California Institute for Mexico and the United States (UC MEXUS CN-16-120). Collaborators include Kevin Wright, Tripti Bhattacharya, Kathleen Johnson, Laura Beramendi-Orosco, Juan Cancino, and Sergio Sanchez-Armass. 


\section{References}

Acuna-Soto, R., Stahle, D. W., Therrell, M. D., Chavez, S. G., \& Cleaveland, M. K. (2005).

Drought, epidemic disease, and the fall of classic period cultures in Mesoamerica (AD 750950). Hemorrhagic fevers as a cause of massive population loss. Medical Hypotheses. https://doi.org/10.1016/j.mehy.2005.02.025

Arnold, P. J. (2000). Sociopolitical complexity and the gulf Olmecs: A view from the Tuxtla Mountains, Veracruz, Mexico. Olmec Art and Archaeology in Mesoamerica, 58, 116-135. http://www.jstor.org/stable/42622270

Asmerom, Y., Baldini, J. U. L., Prufer, K. M., Polyak, V. J., Ridley, H. E., Aquino, V. V., Baldini, L. M., Breitenbach, S. F. M., Macpherson, C. G., \& Kennett, D. J. (2020). Intertropical convergence zone variability in the Neotropics during the Common Era. Science Advances, 6(7), eaax3644. https://doi.org/10.1126/sciadv.aax3644

Baldini, L. M., Baldini, J. U. L., McElwaine, J. N., Frappier, A. B., Asmerom, Y., Liu, K. B., Prufer, K. M., Ridley, H. E., Polyak, V., Kennett, D. J., MacPherson, C. G., Aquino, V. V., Awe, J., \& Breitenbach, S. F. M. (2016). Persistent northward North Atlantic tropical cyclone track migration over the past five centuries. Scientific Reports, 6 . https://doi.org/10.1038/srep37522

Bernal, J. P., Lachniet, M. S., McCulloch, M., Mortimer, G., Morales, P., \& Cienfuegos, E. (2011). A speleothem record of Holocene climate variability from southwestern Mexico. Quaternary Research, 75(1), 104-113. https://doi.org/10.1016/j.yqres.2010.09.002

Bhattacharya, T., Byrne, R., Böhnel, H., Wogau, K., Kienel, U., Ingram, B. L., \& Zimmerman, S. (2015). Cultural implications of late holocene climate change in the Cuenca Oriental, Mexico. Proceedings of the National Academy of Sciences of the United States of America, 112(6), 1693-1698. https://doi.org/10.1073/pnas.1405653112

Bhattacharya, T., \& Chiang, J. C. H. (2014). Spatial variability and mechanisms underlying El Niño-induced droughts in Mexico. Climate Dynamics, 43(12), 3309-3326. https://doi.org/10.1007/s00382-014-2106-8

Bhattacharya, T., Chiang, J. C. H., \& Cheng, W. (2017). Ocean-atmosphere dynamics linked to 800-1050 CE drying in mesoamerica. Quaternary Science Reviews, 169, 263-277. https://doi.org/10.1016/j.quascirev.2017.06.005

Breitenbach, S. F. M., Rehfeld, K., Goswami, B., Baldini, J. U. L., Ridley, H. E., Kennett, D. J., Prufer, K. M., Aquino, V. V., Asmerom, Y., Polyak, V. J., Cheng, H., Kurths, J., \& Marwan, N. (2012). Constructing proxy records from age models (COPRA). Climate of the Past, 8(5), 1765-1779. https://doi.org/10.5194/cp-8-1765-2012

Buntgen, U., Tegel, W., Nicolussi, K., McCormick, M., Frank, D., Trouet, V., Kaplan, J. O., Herzig, F., Heussner, K.-U., Wanner, H., Luterbacher, J., \& Esper, J. (2011). 2500 Years of European Climate Variability and Human Susceptibility. Science, 331(6017), 578-582. https://doi.org/10.1126/science.1197175

Cook, E. R., Seager, R., Kushnir, Y., Briffa, K. R., Büntgen, U., Frank, D., Krusic, P. J., Tegel, W., Schrier, G. Vander, Andreu-Hayles, L., Baillie, M., Baittinger, C., Bleicher, N., Bonde, N., Brown, D., Carrer, M., Cooper, R., Eùfar, K., DIttmar, C., ... Zang, C. (2015). Old World megadroughts and pluvials during the Common Era. Science Advances, 1(10). https://doi.org/10.1126/sciadv.1500561

Cowgill, G. L. (2013). Possible migrations and shifting identities in the central Mexican 
epiclassic. Ancient Mesoamerica, 24(1), 131-149.

https://doi.org/10.1017/S0956536113000060

Cuna, E., Zawisza, E., Caballero, M., Ruiz-Fernández, A. C., Lozano-García, S., \& Alcocer, J. (2013). Environmental impacts of Little Ice Age cooling in central Mexico recorded in the sediments of a tropical alpine lake. J Paleolimnol, 51(1), 1-14. https://doi.org/10.1007/s10933-013-9748-0

Curtis, J. H., Hodell, D. A., \& Brenner, M. (1996). Climate variability on the Yucatan Peninsula (Mexico) during the past 3500 years, and implications for Maya cultural evolution. Quaternary Research, 46(1), 37-47. https://doi.org/10.1006/qres.1996.0042

Davies, S. J., Metcalfe, S. E., Aston, B. J., Byrne, R. A., Champagne, M. R., Jones, M. D., Leng, M. J., \& Noren, A. (2018). A 6,000 year record of environmental change from the eastern Pacific margin of central Mexico. Quaternary Sci Rev. https://doi.org/10.1016/j.quascirev.2018.11.008

De Tapia, E. M. C. (2012). Silent hazards, invisible risks: Prehispanic erosion in the teotihuacan valley, central Mexico. In Surviving Sudden Environmental Change: Answers from Archaeology (pp. 143-165).

Drake, B. L. (2017). Changes in North Atlantic Oscillation drove Population Migrations and the Collapse of the Western Roman Empire. Scientific Reports, 7(1). https://doi.org/10.1038/s41598-017-01289-z

Dull, R. A., Southon, J. R., Kutterolf, S., Anchukaitis, K. J., Freundt, A., Wahl, D. B., Sheets, P., Amaroli, P., Hernandez, W., Wiemann, M. C., \& Oppenheimer, C. (2019). Radiocarbon and geologic evidence reveal Ilopango volcano as source of the colossal 'mystery' eruption of 539/40 CE. Quaternary Science Reviews, 222.

https://doi.org/10.1016/j.quascirev.2019.07.037

Edwards, R. L., Chen, J. H., \& Wasserburg, G. J. (1987). 238U234U230Th232Th systematics and the precise measurement of time over the past 500,000 years. Earth and Planetary Science Letters, 81(2-3), 175-192. https://doi.org/10.1016/0012-821X(87)90154-3

Enfield, D. B., Mestas-Nuñez, A. M., \& Trimble, P. J. (2001). The Atlantic multidecadal oscillation and its relation to rainfall and river flows in the continental U.S. Geophysical Research Letters, 28(10), 2077-2080. https://doi.org/10.1029/2000GL012745

Gautier, E., Savarino, J., Hoek, J., Erbland, J., Caillon, N., Hattori, S., Yoshida, N., Albalat, E., Albarede, F., \& Farquhar, J. (2019). 2600-Years of Stratospheric Volcanism Through Sulfate Isotopes. Nature Communications, 10(1). https://doi.org/10.1038/s41467-01908357-0

Giannini, A., Kushnir, Y., \& Cane, M. A. (2000). Interannual variability of Caribbean rainfall, ENSO, and the Atlantic Ocean. 13(2), 297-311. https://doi.org/10.1175/15200442(2000)013<0297:IVOCRE $>2.0 . C O ; 2$

González-Partida, E., Camprubí, A., Carrillo-Chávez, A., Díaz-Carreño, E. H., González-Ruiz, L. E., Farfán-Panamá, J. L., Cienfuegos-Alvarado, E., Morales-Puente, P., \& VázquezRamírez, J. T. (2019). Giant fluorite mineralization in central mexico by means of exceptionally low salinity fluids: An unusual style among MVT deposits. Minerals, 9(1). https://doi.org/10.3390/min9010035

Graham, N. E., Ammann, C. M., Fleitmann, D., Cobb, K. M., \& Luterbacher, J. (2011). Support for global climate reorganization during the "Medieval Climate Anomaly." Climate Dynamics. https://doi.org/10.1007/s00382-010-0914-z

Greene, C. A., Thirumalai, K., Kearney, K. A., Delgado, J. M., Schwanghart, W., Wolfenbarger, 
N. S., Thyng, K. M., Gwyther, D. E., Gardner, A. S., \& Blankenship, D. D. (2019). The Climate Data Toolbox for MATLAB. Geochemistry, Geophysics, Geosystems, 20(7), 37743781. https://doi.org/10.1029/2019GC008392

Grinsted, A., Moore, J. C., \& Jevrejeva, S. (2004). Application of the cross wavelet transform and wavelet coherence to geophysical time series. Nonlinear Processes in Geophysics. https://doi.org/10.5194/npg-11-561-2004

Haug, G. H., Hughen, K. A., Sigman, D. M., \& Peterson, L. C. (2001). Southward migration of the intertropical convergence zone through the Holocene. Science.

Hellin, J., Bellon, M. R., \& Hearne, S. J. (2014). Maize landraces and adaptation to climate change in Mexico. Journal of Crop Improvement, 28, 484-501. https://doi.org/10.1080/15427528.2014.921800

Hodell, D. A., Brenner, M., \& Curtis, J. H. (2005). Terminal Classic drought in the northern Maya lowlands inferred from multiple sediment cores in Lake Chichancanab (Mexico). Quaternary Science Reviews, 24(12-13), 1413-1427. https://doi.org/10.1016/j.quascirev.2004.10.013

Hodell, D. A., Brenner, M., \& Curtis, J. H. (2007). Climate and cultural history of the Northeastern Yucatan Peninsula, Quintana Roo, Mexico. Climatic Change, 83(1-2), 215240. https://doi.org/10.1007/s10584-006-9177-4

Hodell, D. A., Brenner, M., Curtis, J. H., Medina-González, R., Ildefonso-Chan Can, E., Albornaz-Pat, A., \& Guilderson, T. P. (2005). Climate change on the Yucatan Peninsula during the Little Ice Age. Quaternary Research, 63(2), 109-121. https://doi.org/10.1016/j.yqres.2004.11.004

Hodell, D. A., Curtis, J. H., \& Brenner, M. (1995). Possible role of climate in the collapse of Classic Maya civilization. Nature, 375(6530), 391-394. https://doi.org/10.1038/375391a0

Hunter, S., Allen, D., \& Kohfeld, K. (2019). Spatial and temporal variability of Terminal Classic Period droughts from multiple proxy records on the Yucatan Peninsula, Mexico. Climate of the Past Discussions. https://doi.org/10.5194/cp-2019-68

Hurrell, J. W., \& Deser, C. (2010). North Atlantic climate variability: The role of the North Atlantic Oscillation. Journal of Marine Systems, 79(3-4), 231-244. https://doi.org/10.1016/j.jmarsys.2009.11.002

Kennett, D. J., Breitenbach, S. F. M., Aquino, V. V., Asmerom, Y., Awe, J., Baldini, J. U. L., Bartlein, P., Culleton, B. J., Ebert, C., Jazwa, C., Macri, M. J., Marwan, N., Polyak, V., Prufer, K. M., Ridley, H. E., Sodemann, H., Winterhalder, B., \& Haug, G. H. (2012). Development and Disintegration of Maya Political Systems in Response to Climate Change. Science, 338(6108), 788-791. https://doi.org/10.1126/science.1226299

Knight, J. R., Folland, C. K., \& Scaife, A. A. (2006). Climate impacts of the Atlantic multidecadal oscillation. Geophysical Research Letters, 33(17). https://doi.org/10.1029/2006GL026242

Lachniet, M. S., Asmerom, Y., Bernal, J. P., Polyak, V. J., \& Vazquez-Selem, L. (2013). Orbital pacing and ocean circulation-induced collapses of the Mesoamerican monsoon over the past 22,000 y. Proceedings of the National Academy of Sciences, 110(23), 9255-9260. https://doi.org/10.1073/pnas.1222804110

Lachniet, M. S., Asmerom, Y., Polyak, V., \& Bernal, J. P. (2017). Two millennia of Mesoamerican monsoon variability driven by Pacific and Atlantic synergistic forcing. Quaternary Science Reviews, 155, 100-113. https://doi.org/10.1016/j.quascirev.2016.11.012 
Lachniet, M. S., Bernal, J. P., Asmerom, Y., Polyak, V., \& Piperno, D. (2012). A 2400 yr Mesoamerican rainfall reconstruction links climate and cultural change. Geology, 40(3), 259-262. https://doi.org/10.1130/G32471.1

Larsen, L. B., Vinther, B. M., Briffa, K. R., Melvin, T. M., Clausen, H. B., Jones, P. D., Siggaard-Andersen, M. L., Hammer, C. U., Eronen, M., Grudd, H., Gunnarson, B. E., Hantemirov, R. M., Naurzbaev, M. M., \& Nicolussi, K. (2008). New ice core evidence for a volcanic cause of the A.D. 536 dust veil. Geophysical Research Letters, 35(4). https://doi.org/10.1029/2007GL032450

Lases-Hernandez, F., Medina-Elizalde, M., Burns, S., \& DeCesare, M. (2019). Long-term monitoring of drip water and groundwater stable isotopic variability in the Yucatán Peninsula: Implications for recharge and speleothem rainfall reconstruction. Geochimica et Cosmochimica Acta, 246, 41-59. https://doi.org/10.1016/j.gca.2018.11.028

Lee, J. Y., \& Wang, B. (2014). Future change of global monsoon in the CMIP5. Climate Dynamics. https://doi.org/10.1007/s00382-012-1564-0

Lemos-Espinal, J. A., Smith, G. R., \& Woolrich-Piña, G. A. (2018). Amphibians and reptiles of the state of San Luis Potosí, Mexico, with comparisons with adjoining states. ZooKeys. https://doi.org/10.3897/zookeys.753.21094

Mann, M. E., Zhang, Z., Rutherford, S., Bradley, R. S., Hughes, M. K., Shindell, D., Ammann, C., Faluvegi, G., \& Ni, F. (2009). Global signatures and dynamical origins of the little ice age and medieval climate anomaly. Science. https://doi.org/10.1126/science.1177303

Martinez, S. E., Escolero, O., \& Wolf, L. (2011). Total Urban Water Cycle Models in Semiarid Environments-Quantitative Scenario Analysis at the Area of San Luis Potosi, Mexico. Water Resources Management. https://doi.org/10.1007/s11269-010-9697-6

Medina-Elizalde, M., Burns, S. J., Polanco-Martínez, J. M., Beach, T., Lases-Hernández, F., Shen, C. C., \& Wang, H. C. (2016). High-resolution speleothem record of precipitation from the Yucatan Peninsula spanning the Maya Preclassic Period. Global and Planetary Change, 138, 93-102. https://doi.org/10.1016/j.gloplacha.2015.10.003

Medina-Elizalde, M., Polanco-Martínez, J. M., Lases-Hernández, F., Bradley, R., \& Burns, S. (2016). Testing the "tropical storm" hypothesis of Yucatan Peninsula climate variability during the Maya Terminal Classic Period. Quaternary Research, 86(2), 111-119. https://doi.org/10.1016/j.yqres.2016.05.006

Medina-Elizalde, M., \& Rohling, E. J. (2012). Collapse of classic maya civilization related to modest reduction in precipitation. Science, 335(6071), 956-959. https://doi.org/10.1126/science.1216629

Mejía Ramón, A. G., \& Johnson, N. E. (2019). Sociopolitical organization, landscape change, and hydraulic engineering in the Teotihuacan Valley, Mexico: 1250 B.C.-A.D. 1810. Wiley Interdisciplinary Reviews: Water, 6(2), e1335. https://doi.org/10.1002/wat2.1335

Méndez, M., \& Magaña, V. (2010). Regional Aspects of Prolonged Meteorological Droughts over Mexico and Central America. Journal of Climate, 23(5), 1175-1188. https://doi.org/10.1175/2009JCLI3080.1

Neff, H., Pearsall, D. M., Jones, J. G., Arroyo de Pieters, B., \& Freidel, D. E. (2006). Climate change and population history in the Pacific Lowlands of Southern Mesoamerica. Quaternary Research, 65(3), 390-400. https://doi.org/10.1016/j.yqres.2005.10.002

Olsen, J., Anderson, N. J., \& Knudsen, M. F. (2012). Variability of the North Atlantic Oscillation over the past 5,200 years. Nature Geoscience, 5(11), 808-812. https://doi.org/10.1038/ngeo1589 
Oster, J., Warken, S., Sekhon, N., Arienzo, M., \& Lachniet, M. S. (2019). Speleothem Paleoclimatology for the Caribbean, Central America, and North America. Quaternary, 2(1), 5. https://doi.org/10.3390/quat2010005

PAGES 2k Consortium, Ahmed, M., Anchukaitis, K. J., Asrat, A., Borgaonkar, H. P., Braida, M., Buckley, B. M., Büntgen, U., Chase, B. M., Christie, D. A., Cook, E. R., Curran, M. A. J., Diaz, H. F., Esper, J., Fan, Z. X., Gaire, N. P., Ge, Q., Gergis, J., González-Rouco, J. F., ... Zorita, E. (2013). Continental-scale temperature variability during the past two millennia. Nature Geoscience, 6(5), 339-346. https://doi.org/10.1038/ngeo1797

Park, J., Byrne, R., \& Böhnel, H. (2017). The combined influence of Pacific decadal oscillation and Atlantic multidecadal oscillation on central Mexico since the early 1600s. Earth and Planetary Science Letters. https://doi.org/10.1016/j.epsl.2017.02.013

Park, J., Byrne, R., \& Böhnel, H. (2019). Late Holocene Climate Change in Central Mexico and the Decline of Teotihuacan. Annals of the American Association of Geographers, 109(1), 104-120. https://doi.org/10.1080/24694452.2018.1488577

Pearl, J. K., Anchukaitis, K. J., Donnelly, J. P., Pearson, C., Pederson, N., Lardie Gaylord, M. C., McNichol, A. P., Cook, E. R., \& Zimmermann, G. L. (2020). A late Holocene subfossil Atlantic white cedar tree-ring chronology from the northeastern United States. Quaternary Science Reviews, 228. https://doi.org/10.1016/j.quascirev.2019.106104

Poore, R. Z., DeLong, K. L., Richey, J. N., \& Quinn, T. M. (2009). Evidence of multidecadal climate variability and the Atlantic Multidecadal Oscillation from a Gulf of Mexico seasurface temperature-proxy record. Geo-Marine Letters, 29(6), 477-484. https://doi.org/10.1007/s00367-009-0154-6

Rodríguez-Alegría, E. (2017). A City Transformed: From Tenochtitlan to Mexico City in the Sixteenth Cen-tury. The Oxford Handbook of the Aztecs, January, 1-15. https://doi.org/10.1093/oxfordhb/9780199341962.013.27

Rodriguez-Vera, G., Romero-Centeno, R., Castro, C. L., \& Castro, V. M. (2019). Coupled interannual variability of wind and sea surface temperature in the Caribbean Sea and the Gulf of Mexico. Journal of Climate, 32(14), 4263-4280. https://doi.org/10.1175/JCLI-D18-0573.1

Roy, P. D., Rivero-Navarrete, A., Sánchez-Zavala, J. L., Beramendi-Orosco, L. E., MuthuSankar, G., \& Lozano-Santacruz, R. (2016). Atlantic Ocean modulated hydroclimate of the subtropical northeastern Mexico since the last glacial maximum and comparison with the southern US. Earth and Planetary Science Letters, 434, 141-150. https://doi.org/10.1016/j.eps1.2015.11.048

Scheff, J., Seager, R., Liu, H., \& Coats, S. (2017). Are glacials dry? Consequences for paleoclimatology and for greenhouse warming. Journal of Climate, 30(17), 6593-6609. https://doi.org/10.1175/JCLI-D-16-0854.1

Schneider, U., Becker, A., Finger, P., Meyer-Christoffer, A., Rudolf, B., \& Ziese, M. (2015). GPCC Full Data Reanalysis Version 7.0 at $0.5^{\circ}$ : Monthly Land-Surface Precipitation from Rain-Gauges built on GTS-based and Historic Data. In Global Precipitation Climatology Centre. https://doi.org/10.5676/DWD_GPCC/FD_M V6 050

Schneider, U., Becker, A., Finger, P., Meyer-Christoffer, A., Ziese, M., \& Rudolf, B. (2014). GPCC's new land surface precipitation climatology based on quality-controlled in situ data and its role in quantifying the global water cycle. Theoretical and Applied Climatology, 115(1-2), 15-40. https://doi.org/10.1007/s00704-013-0860-x

Sigl, M., Winstrup, M., McConnell, J. R., Welten, K. C., Plunkett, G., Ludlow, F., Büntgen, U., 
Caffee, M., Chellman, N., Dahl-Jensen, D., Fischer, H., Kipfstuhl, S., Kostick, C., Maselli, O. J., Mekhaldi, F., Mulvaney, R., Muscheler, R., Pasteris, D. R., Pilcher, J. R., ...

Woodruff, T. E. (2015). Timing and climate forcing of volcanic eruptions for the past 2,500 years. Nature, 523(7562), 543-549. https://doi.org/10.1038/nature14565

Stahle, D. W., Diaz, J. V., Burnette, D. J., Paredes, J. C., Heim, R. R., Fye, F. K., Soto, R. A., Therrell, M. D., Cleaveland, M. K., \& Stahle, D. K. (2011). Major Mesoamerican droughts of the past millennium. Geophysical Research Letters, 38(5). https://doi.org/10.1029/2010GL046472

Stahle, D. W., Cook, E. R., Burnette, D. J., Villanueva, J., Cerano, J., Burns, J. N., Griffin, D., Cook, B. I., Acuña, R., Torbenson, M. C. A., Sjezner, P., \& Howard, I. M. (2016). The Mexican Drought Atlas: Tree-ring reconstructions of the soil moisture balance during the late pre-Hispanic, colonial, and modern eras. Quaternary Science Reviews, 149, 34-60. https://doi.org/10.1016/j.quascirev.2016.06.018

Stein, A. F., Draxler, R. R., Rolph, G. D., Stunder, B. J. B., Cohen, M. D., \& Ngan, F. (2015). Noaa's hysplit atmospheric transport and dispersion modeling system. Bulletin of the American Meteorological Society, 96(12), 2059-2077. https://doi.org/10.1175/BAMS-D14-00110.1

Trouet, V., Esper, J., Graham, N. E., Baker, A., Scourse, J. D., \& Frank, D. C. (2009). Persistent positive north atlantic oscillation mode dominated the medieval climate anomaly. Science. https://doi.org/10.1126/science.1166349

Villalba, R. (1994). Tree-ring and glacial evidence for the Medieval Warm Epoch and the Little Ice Age in southern South America. The Medieval Warm Period. https://doi.org/10.1007/978-94-011-1186-7_4

Wang, T., Surge, D., \& Walker, K. J. (2013). Seasonal climate change across the Roman Warm Period/Vandal Minimum transition using isotope sclerochronology in archaeological shells and otoliths, southwest Florida, USA. Quaternary International, 308-309, 230-241. https://doi.org/10.1016/j.quaint.2012.11.013

Warner, M. S. C. (2018). Introduction to PySPLIT: A python toolkit for NOAA ARL's HYSPLIT model. Computing in Science and Engineering, 20(5), 47-62. https://doi.org/10.1109/MCSE.2017.3301549

Williams, A. P., Cook, E. R., Smerdon, J. E., Cook, B. I., Abatzoglou, J. T., Bolles, K., Baek, S. H., Badger, A. M., \& Livneh, B. (2020). Large contribution from anthropogenic warming to an emerging North American megadrought. Science, 368(6488), 314-318. https://doi.org/10.1126/science.aaz9600

Winter, A., Zanchettin, D., Lachniet, M., Vieten, R., Pausata, F. S. R., Ljungqvist, F. C., Cheng, H., Edwards, R. L., Miller, T., Rubinetti, S., Rubino, A., \& Taricco, C. (2020). Initiation of a stable convective hydroclimatic regime in Central America circa 9000 years BP. Nature Communications, 11(1). https://doi.org/10.1038/s41467-020-14490-y

Winter, A., Zanchettin, D., Miller, T., Kushnir, Y., Black, D., Lohmann, G., Burnett, A., Haug, G. H., Estrella-Martinez, J., Breitenbach, S. F. M., Beaufort, L., Rubino, A., \& Cheng, H. (2015). Persistent drying in the tropics linked to natural forcing. Nature Communications, 6(1), 7627. https://doi.org/10.1038/ncomms8627

Wong, C. I., Banner, J. L., \& Musgrove, M. (2015a). Holocene climate variability in Texas, USA: An integration of existing paleoclimate data and modeling with a new, highresolution speleothem record. Quaternary Sci Rev, 127. https://doi.org/10.1016/j.quascirev.2015.06.023 
Wong, C. I., Banner, J. L., \& Musgrove, M. (2015b). Holocene climate variability in Texas, USA: An integration of existing paleoclimate data and modeling with a new, highresolution speleothem record. Quaternary Science Reviews, 127, 155-173. https://doi.org/10.1016/j.quascirev.2015.06.023

Wright, K., Johnson, K.R., Serrato Marks, G., McGee, D., Bhattacharya, T., Goldsmith, G., Tabor, C., Lacaille-Muzquiz, J.-L., Lum, G., Beramendi-Orosco, L., Precipitation in Mexico dominated by changes in Atlantic Meridional Overturning Circulation, in prep. for Science Advances.

\section{Appendix A: Figures and Supplementary Information}

We also sampled CP5, a small ( $<10 \mathrm{~cm}$ long) stalagmite with significant hiatuses. CP5 overlapped with CP2 for decades at the beginning and end of CP2's growth period, but did not capture the majority of the first millennium. Because of its significant growth irregularities, CP5 serves as a comparison, similar to a farmed calcite growth plate. CP5 did not capture enough time to be helpful alone. In comparison with $\mathrm{CP} 5, \mathrm{Mg} / \mathrm{Ca}$ and stable isotope ratios from $\mathrm{CP} 2$ overlap within error, suggesting that the cave environment is producing reproducible geochemical signals despite intra-drip differences. 


\section{Juxtlahuaca}

\section{Yok Balum}

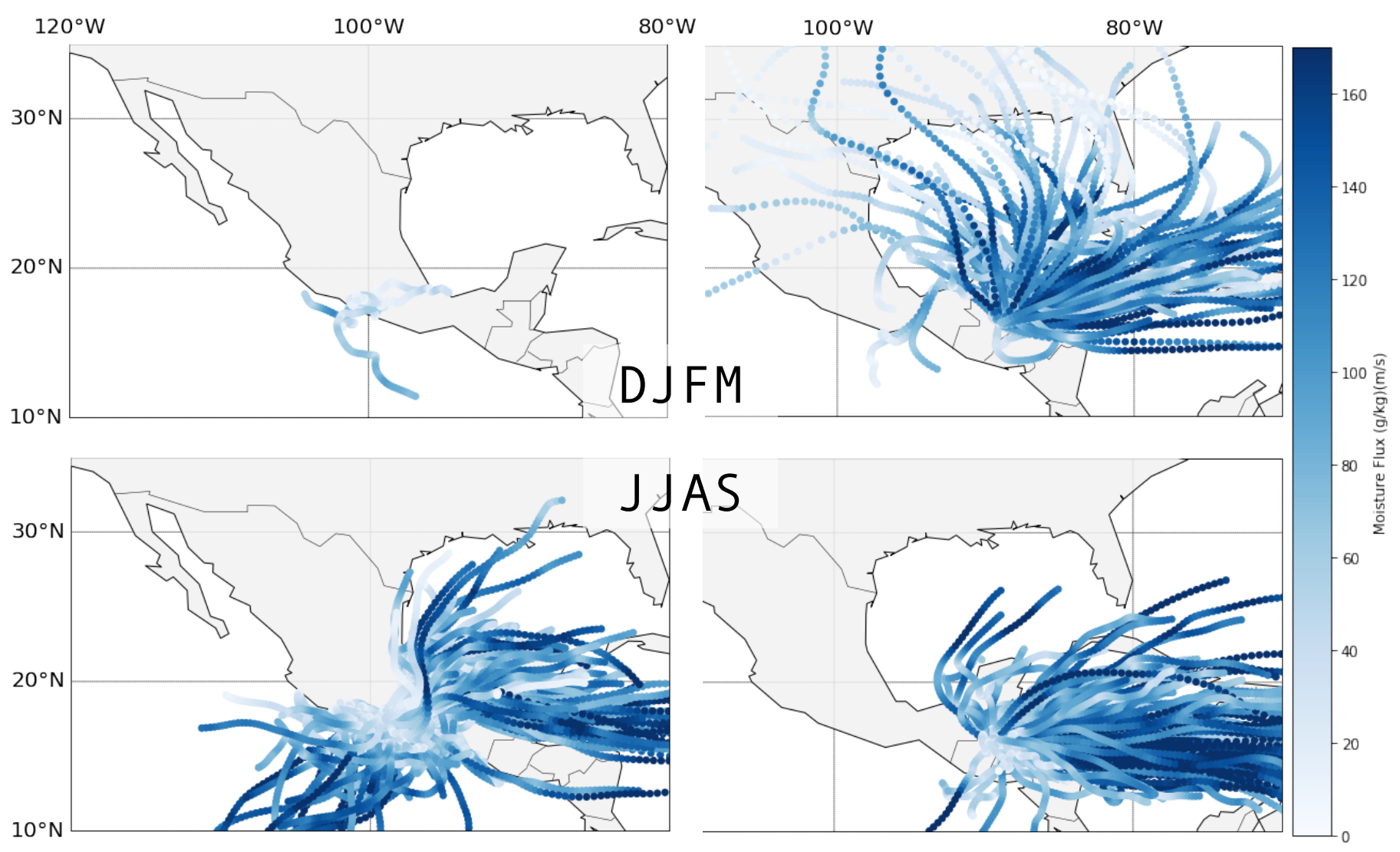

Figure A1. Rain-bearing trajectories for Juxtlahuaca and Yok Balum caves from 2005 to 2008 during DJFM (top) and JJAS (bottom). Juxtlahuaca has more Pacific-derived moisture than Yok Balum and Cueva de la Puente (this study, Figure 2).

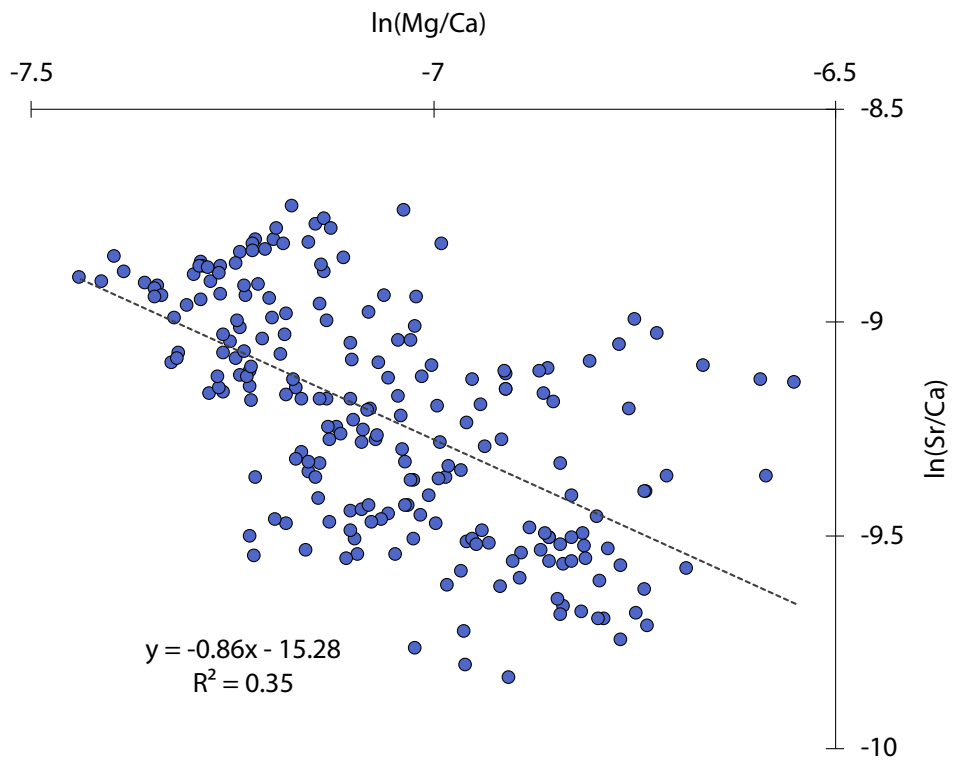


Figure A2. Comparison of $\mathrm{Mg} / \mathrm{Ca}$ and $\mathrm{Sr} / \mathrm{Ca}$ reveals that they are anti-correlated, suggesting that $\mathrm{Sr} / \mathrm{Ca}$ is controlled by another mechanism, not necessarily precipitation. It is the inverse of the relationship expected if both ratios are driven by prior calcite precipitation.

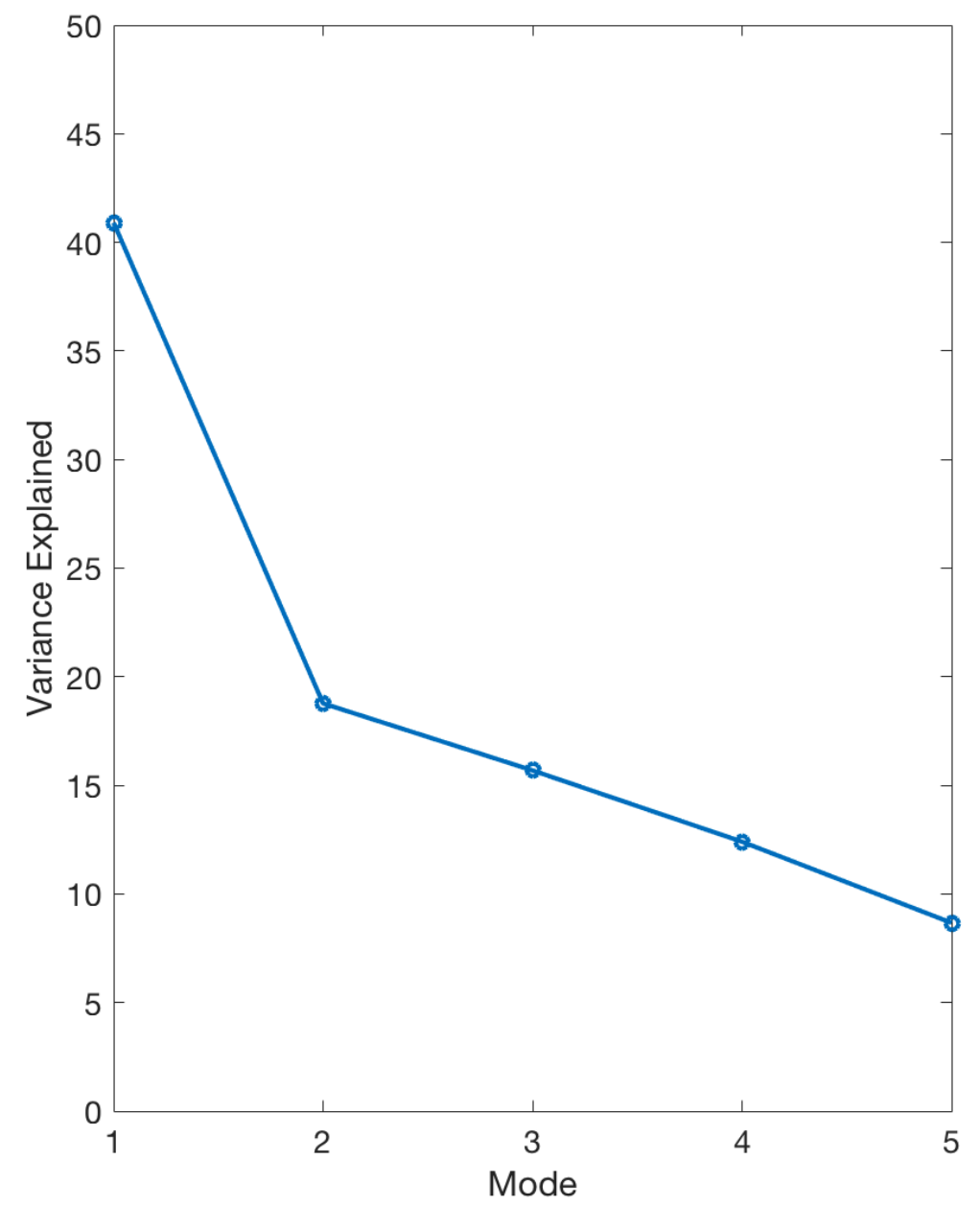

Figure A3. Variance explained by modes 1 through 5 of the EOF analysis. Mode 1 is statistically significant based on the scree slope test. 


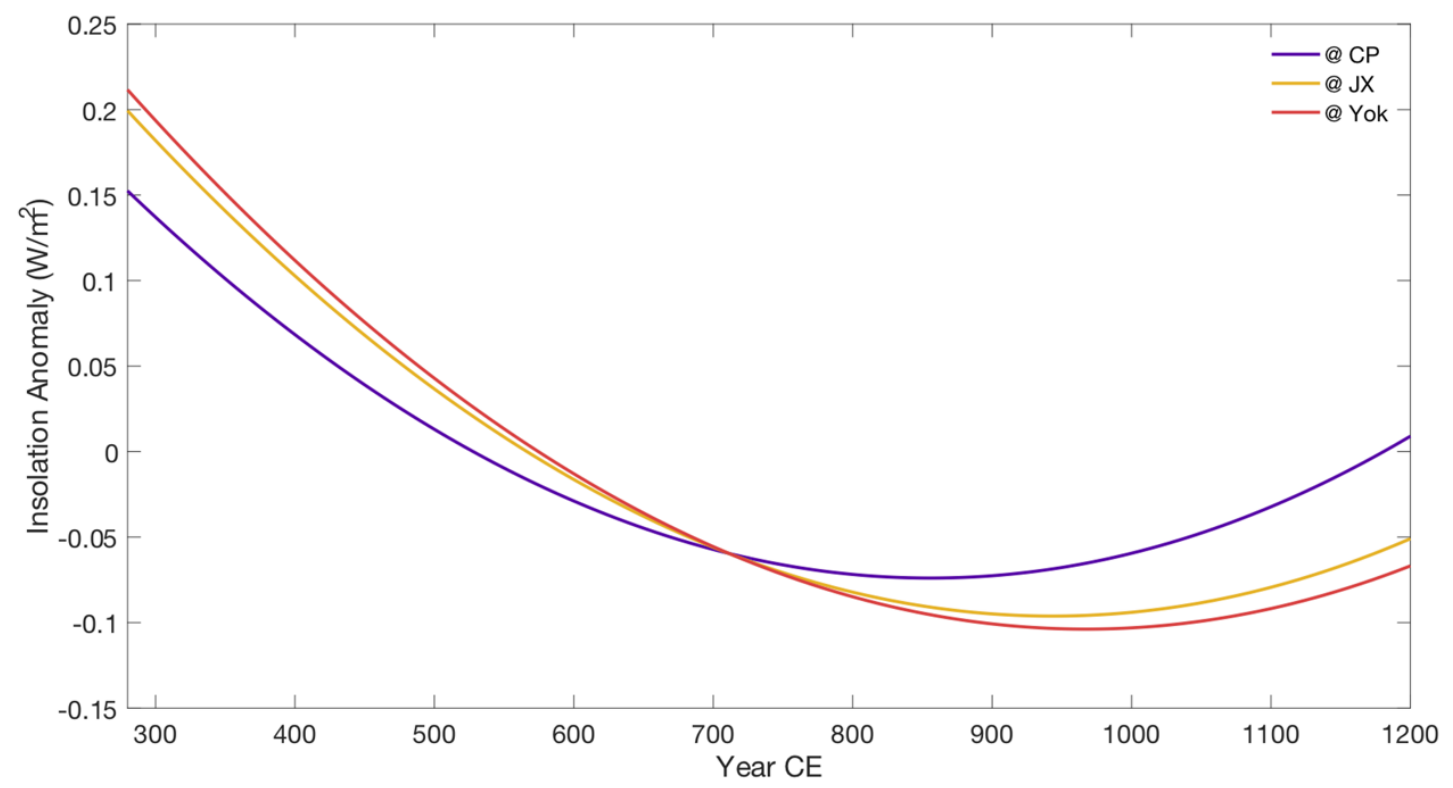

Figure A4. June 21 Insolation anomaly at CP, Juxtlahuaca, and Yok Balum, generated with the climate data toolbox from Greene et al. (2019).

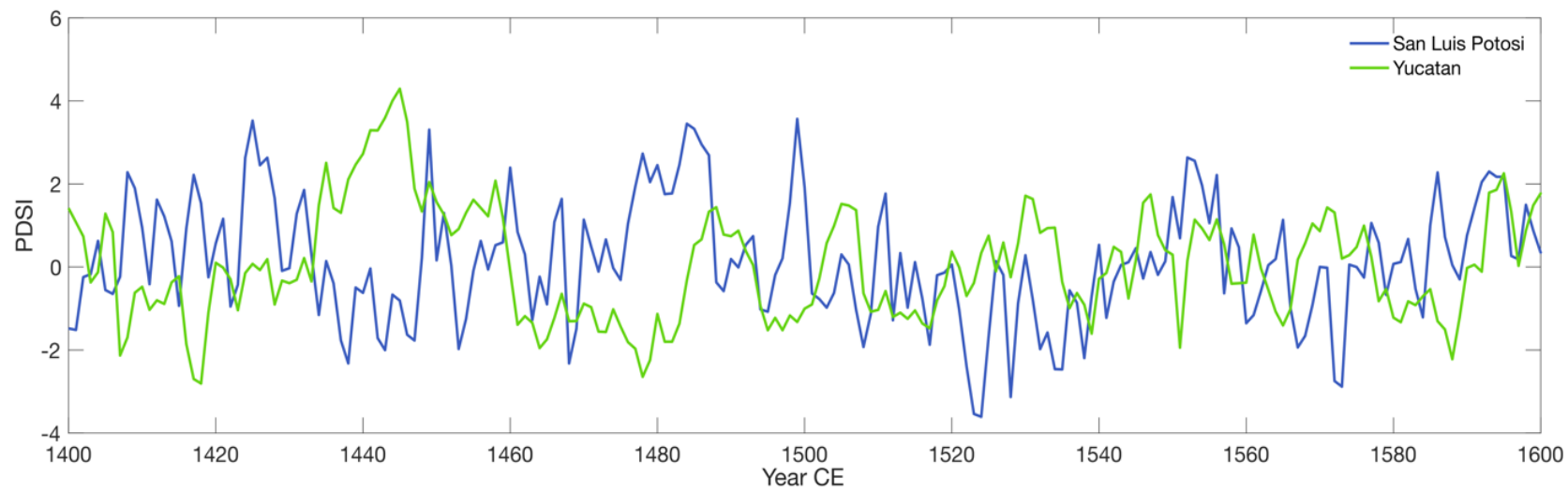

Figure A5. Reconstructed Palmer Drought Severity Index (PDSI) for San Luis Potosí and the Yucatán Peninsula (JJA) (Stahle et al., 2016). 


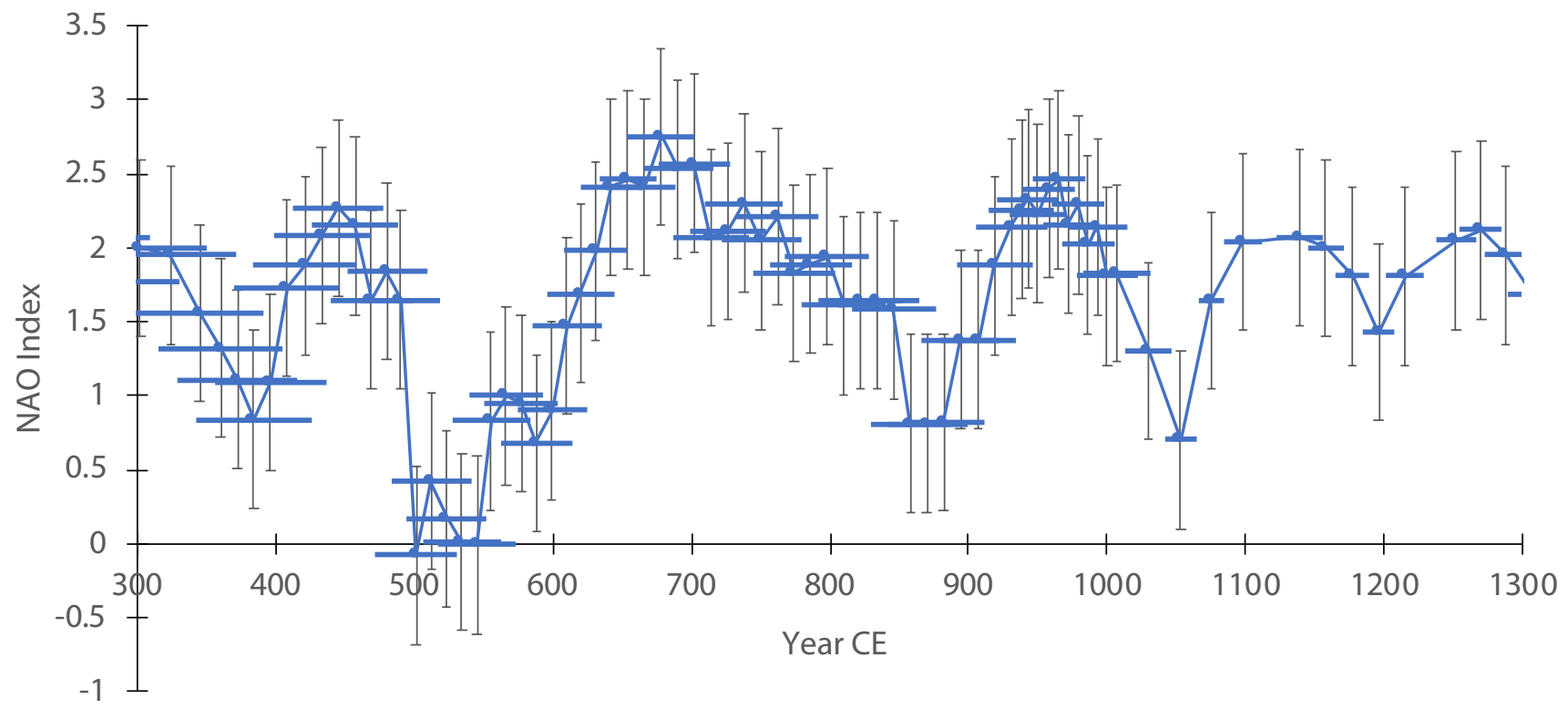

Figure A6. A subset of reconstructed North Atlantic Oscillation (NAO) index values from Olsen et al. (2012). Blue horizontal bars indicate age model uncertainty, black vertical bars indicate index uncertainty ( \pm 0.6 throughout the record).

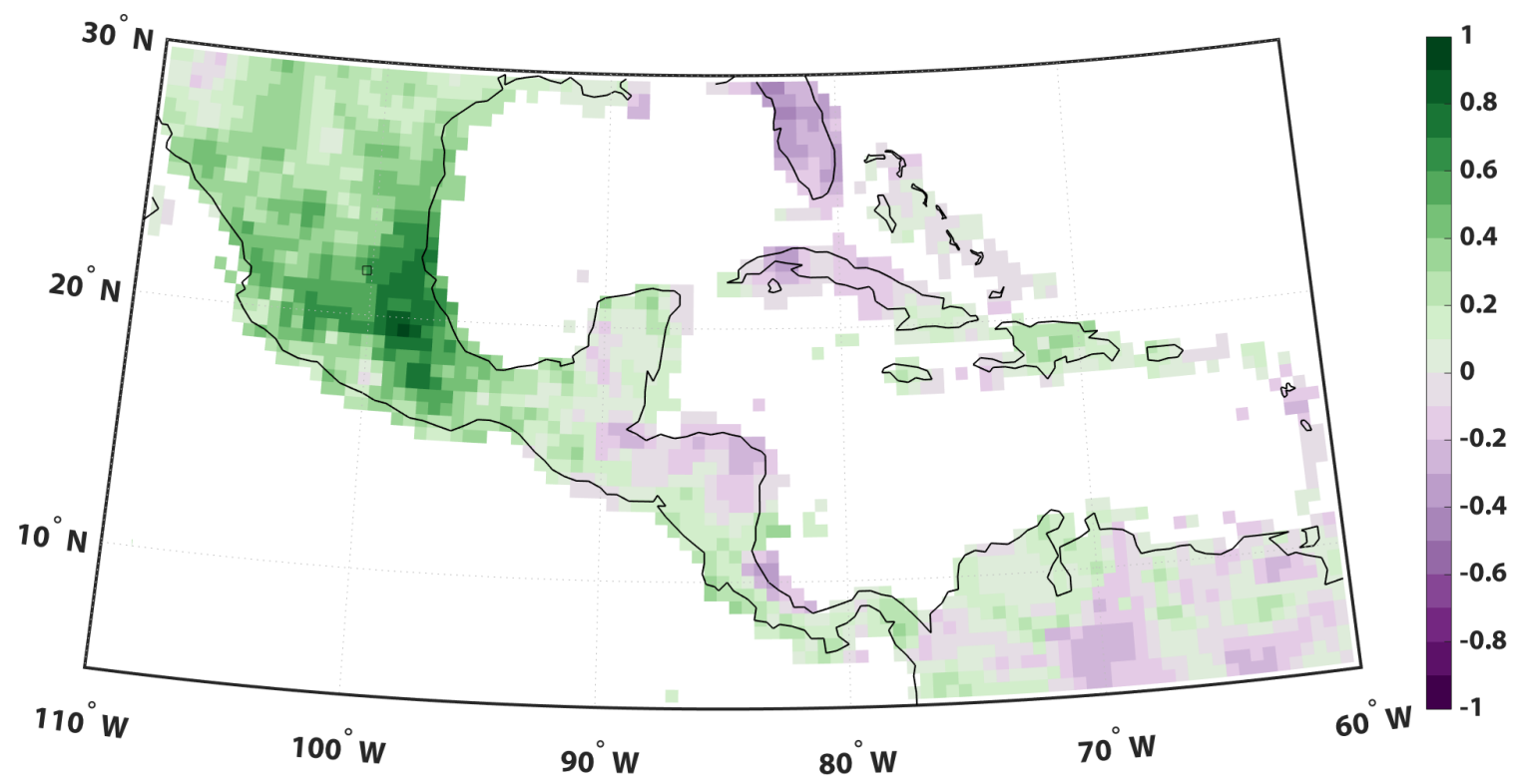

Figure A7. Correlation between rainfall at Teotihuacan over 1950 to 2000 compared to all other grid points in GPCC data (similar to Figure 1B in the main text). Black square denotes CP site. 


\section{Appendix B: Data}

Table 1. U-Series data for 14 CP2 samples, based on analysis at MIT between 2017 and 2020.

Dates are shown in Table 2.

\begin{tabular}{|c|c|c|c|c|c|c|c|c|c|c|c|}
\hline $\begin{array}{c}\text { Sample } \\
\text { ID }\end{array}$ & $\begin{array}{c}\text { Depth } \\
\text { mm }\end{array}$ & $\begin{array}{l}{ }^{238} \mathrm{U} \\
\mathrm{ng} / \mathrm{g}\end{array}$ & $\begin{array}{c} \pm \\
2 \sigma\end{array}$ & $\begin{array}{c}{ }^{232} \mathrm{Th} \\
\mathrm{pg} / \mathrm{g}\end{array}$ & $\pm 2 \sigma$ & $\begin{array}{c}\mathbf{d}^{234} \mathbf{U} \\
\% 0\end{array}$ & $\begin{array}{c} \pm \\
2 \sigma\end{array}$ & $\begin{array}{c}{ }^{\left({ }^{230} \mathrm{Th} /\right.} \\
\left.{ }^{238} \mathrm{U}\right) \\
\text { activity }\end{array}$ & $\pm 2 \sigma$ & $\begin{array}{l}{ }^{230} \mathrm{Th} / \\
{ }^{232} \mathrm{Th} \text {, } \\
\mathrm{ppm} \\
\text { atomic }\end{array}$ & $\pm 2 \sigma$ \\
\hline CP2-top & 4 & 1071 & 21 & 2754 & 59.2 & 944 & 1 & 1.94E-02 & 1.89E-04 & 120 & 1.5 \\
\hline CP2-9 & 9 & 1027 & 21 & 258 & 6.6 & 944 & 2 & 1.90E-02 & $2.50 \mathrm{E}-04$ & 1203 & 24.7 \\
\hline CP2-24 & 24 & 1017 & 20 & 504 & 11.0 & 930 & 5 & 1.91E-02 & 2.14E-04 & 613 & 8.6 \\
\hline CP2A & 48 & 1032 & 21 & 394 & 18.0 & 971 & 2 & 2.01E-02 & 1.36E-04 & 838 & 34.9 \\
\hline CP2M & 54 & 816 & 16 & 162 & 5.0 & 940 & 2 & 2.01E-02 & 2.70E-04 & 1612 & 43.3 \\
\hline CP2S & 63 & 610 & 12 & 54 & 4.2 & 970 & 1 & $2.14 \mathrm{E}-02$ & 3.10E-04 & 3847 & 291.3 \\
\hline CP2T & 80 & 590 & 12 & 93 & 4.5 & 957 & 2 & 2.34E-02 & $3.36 \mathrm{E}-04$ & 2345 & 106.8 \\
\hline CP2B & 98 & 851 & 17 & 180 & 17.9 & 967 & 2 & 2.66E-02 & 1.99E-04 & 2002 & 196.3 \\
\hline CP2C & 134 & 1177 & 24 & 295 & 16.6 & 970 & 2 & $2.72 \mathrm{E}-02$ & 1.68E-04 & 1720 & 91.0 \\
\hline CP2D & 170 & 1097 & 22 & 100 & 15.3 & 968 & 2 & 2.78E-02 & 1.71E-04 & 4826 & 730.5 \\
\hline CP2E & 191 & 1396 & 28 & 330 & 17.0 & 987 & 1 & 2.93E-02 & 1.46E-04 & 1968 & 93.6 \\
\hline $\mathrm{CP} 2 \mathrm{~F}$ & 191 & 1430 & 29 & 71 & 18.0 & 987 & 1 & 2.93E-02 & $1.61 \mathrm{E}-04$ & 9356 & 2356.3 \\
\hline CP2G & 241 & 1216 & 24 & 153 & 10.8 & 998 & 1 & $3.11 \mathrm{E}-02$ & 1.67E-04 & 3917 & 265.3 \\
\hline CP2-btm & 273 & 1165 & 23 & 347 & 7.1 & 985 & 1 & $3.12 \mathrm{E}-02$ & 2.69E-04 & 1666 & 16.1 \\
\hline
\end{tabular}

Table 2. U-Series dates $(n=14)$ calculated based on data in Table 1. Ages are given as corrected (corr.) and uncorrected (uncorr.); corrected age in years before present (where present is 1950) was used for age-depth modeling.

\begin{tabular}{|c|c|c|c|c|c|c|c|c|c|c|}
\hline $\begin{array}{l}\text { Sample } \\
\text { ID }\end{array}$ & $\begin{array}{l}\text { Depth } \\
\mathrm{mm}\end{array}$ & $\begin{array}{l}\text { Uncorr. } \\
\text { Age (yr) }\end{array}$ & $\begin{array}{l} \pm \\
2 \sigma\end{array}$ & $\begin{array}{l}\text { Corr. Age } \\
\text { (yr before } \\
\text { chemistry) }\end{array}$ & $\begin{array}{l} \pm \\
2 \sigma\end{array}$ & $\begin{array}{l}\mathbf{d}^{234} \mathbf{U} \\
\text { init. } \\
\% \text { \% }\end{array}$ & $\begin{array}{l} \pm \\
2 \sigma\end{array}$ & $\begin{array}{l}\text { Corr. Age } \\
\text { (yr before } \\
1950)\end{array}$ & $\begin{array}{l} \pm \\
2 \sigma\end{array}$ & $\begin{array}{l}\text { Year of } \\
\text { chemistry } \\
(y r C E)\end{array}$ \\
\hline CP2-top & 4 & 1092 & 11 & 1052 & 23 & 947 & 1.3 & 985 & 23 & 2017 \\
\hline CP2-9 & 9 & 1073 & 14 & 1069 & 14 & 947 & 2.0 & 999 & 14 & 2020 \\
\hline CP2-24 & 24 & 1084 & 13 & 1076 & 13 & 932 & 5.1 & 1006 & 13 & 2020 \\
\hline CP2A & 48 & 1120 & 8 & 1114 & 8 & 974 & 1.9 & 1045 & 8 & 2019 \\
\hline CP2M & 54 & 1136 & 15 & 1133 & 15 & 943 & 1.6 & 1063 & 15 & 2020 \\
\hline CP2S & 63 & 1193 & 17 & 1191 & 17 & 973 & 1.5 & 1121 & 17 & 2020 \\
\hline CP2T & 80 & 1310 & 19 & 1307 & 19 & 960 & 2.3 & 1237 & 19 & 2020 \\
\hline CP2B & 98 & 1485 & 11 & 1482 & 11 & 971 & 1.6 & 1413 & 11 & 2019 \\
\hline CP2C & 134 & 1514 & 9 & 1511 & 10 & 974 & 1.7 & 1442 & 10 & 2019 \\
\hline CP2D & 170 & 1549 & 10 & 1547 & 10 & 972 & 1.9 & 1478 & 10 & 2019 \\
\hline CP2E & 191 & 1620 & 8 & 1616 & 8 & 991 & 1.3 & 1547 & 8 & 2019 \\
\hline CP2F & 191 & 1618 & 9 & 1618 & 9 & 992 & 1.3 & 1549 & 9 & 2019 \\
\hline CP2G & 241 & 1708 & 9 & 1706 & 9 & 1003 & 1.3 & 1637 & 9 & 2019 \\
\hline CP2-btm & 273 & 1727 & 15 & 1723 & 15 & 989 & 0.7 & 1656 & 15 & 2017 \\
\hline
\end{tabular}


Table 3. Geochemical proxy data for CP2 with age in year CE. Data are organized by increasing depth (measured from the top of the stalagmite) and span multiple pages. Missing data is indicated with NaN.

\begin{tabular}{|c|c|c|c|c|c|}
\hline $\begin{array}{c}\text { Depth } \\
\text { mm from top }\end{array}$ & $\begin{array}{c}\text { Age } \\
\text { Year CE }\end{array}$ & $\begin{array}{l}\mathrm{Mg} / \mathrm{Ca} \\
\mathrm{mol} / \mathrm{mol}\end{array}$ & $\begin{array}{c}\mathrm{Sr} / \mathrm{Ca} \\
\mathrm{mol} / \mathrm{mol}\end{array}$ & $\begin{array}{c}\mathbf{d}^{18} \mathbf{O} \\
\%, \text { VPDB }\end{array}$ & $\begin{array}{c}\mathbf{d}^{\mathbf{1 3}} \mathbf{C} \\
\%, \text { VPDB }\end{array}$ \\
\hline 1.00 & 976.1 & $\mathrm{NaN}$ & $\mathrm{NaN}$ & -6.874 & -7.914 \\
\hline 2.00 & 974.2 & 1.099E-03 & 6.267E-05 & $\mathrm{NaN}$ & $\mathrm{NaN}$ \\
\hline 3.00 & 971.3 & 1.128E-03 & 6.162E-05 & $\mathrm{NaN}$ & $\mathrm{NaN}$ \\
\hline 3.75 & 968.9 & $\mathrm{NaN}$ & $\mathrm{NaN}$ & -6.347 & -7.662 \\
\hline 4.25 & 967.2 & 1.120E-03 & 6.160E-05 & $\mathrm{NaN}$ & $\mathrm{NaN}$ \\
\hline 5.00 & 964.2 & 1.186E-03 & 6.604E-05 & $\mathrm{NaN}$ & $\mathrm{NaN}$ \\
\hline 7.00 & 956.5 & 1.175E-03 & $6.247 \mathrm{E}-05$ & -7.147 & -7.911 \\
\hline 9.00 & 951.7 & 9.518E-04 & 7.391E-05 & -7.738 & -8.182 \\
\hline 11.00 & 949.9 & 8.900E-04 & 7.421E-05 & -8.338 & -8.453 \\
\hline 13.00 & 948.4 & 8.301E-04 & 7.166E-05 & -8.691 & -8.352 \\
\hline 15.00 & 947.3 & 7.783E-04 & 7.237E-05 & -8.786 & -8.473 \\
\hline 17.00 & 946.3 & $7.260 \mathrm{E}-04$ & 7.481E-05 & -9.061 & -8.515 \\
\hline 19.50 & 945.0 & 7.307E-04 & 7.152E-05 & -9.282 & -8.533 \\
\hline 22.50 & 943.0 & 8.195E-04 & 7.105E-05 & -8.477 & -8.341 \\
\hline 25.00 & 941.2 & 8.701E-04 & 7.173E-05 & -8.22 & -8.276 \\
\hline 27.00 & 939.2 & 8.021E-04 & 7.720E-05 & -8.294 & -8.365 \\
\hline 29.00 & 937.0 & 1.084E-03 & 8.227E-05 & -6.47 & -7.873 \\
\hline 31.00 & 934.5 & 8.282E-04 & 7.432E-05 & -8.231 & -8.4 \\
\hline 33.00 & 931.7 & $9.290 \mathrm{E}-04$ & 6.679E-05 & -7.835 & -8.085 \\
\hline 34.50 & 929.5 & 1.073E-03 & 7.010E-05 & -7.346 & -7.994 \\
\hline 36.00 & 927.3 & 1.016E-03 & 6.789E-05 & -7.839 & -8.341 \\
\hline 38.00 & 924.0 & 9.925E-04 & 6.648E-05 & -8.117 & -8.424 \\
\hline 40.00 & 920.6 & 1.073E-03 & 6.339E-05 & -7.288 & -8.001 \\
\hline 42.00 & 917.0 & 1.152E-03 & 5.876E-05 & -6.884 & -7.944 \\
\hline 44.00 & 913.1 & 1.069E-03 & $6.229 \mathrm{E}-05$ & -7.666 & -7.862 \\
\hline 46.00 & 909.0 & 1.191E-03 & 6.060E-05 & -8.122 & -8.057 \\
\hline 48.00 & 905.0 & $9.475 \mathrm{E}-04$ & 5.982E-05 & -8.553 & -8.206 \\
\hline 50.00 & 900.2 & 8.928E-04 & 5.747E-05 & -8.424 & -8.245 \\
\hline 51.50 & 895.7 & 9.503E-04 & 5.530E-05 & -8.899 & -8.316 \\
\hline 53.00 & 890.7 & 1.002E-03 & 5.376E-05 & -8.899 & -8.341 \\
\hline 54.00 & 886.8 & 8.848E-04 & 8.037E-05 & -7.965 & -8.106 \\
\hline 54.99 & 882.4 & 8.441E-04 & $1.008 \mathrm{E}-04$ & $\mathrm{NaN}$ & $\mathrm{NaN}$ \\
\hline 55.00 & 882.4 & 7.593E-04 & $1.200 \mathrm{E}-04$ & $\mathrm{NaN}$ & $\mathrm{NaN}$ \\
\hline
\end{tabular}




\begin{tabular}{|c|c|c|c|c|c|}
\hline 55.99 & 877.0 & $\mathrm{NaN}$ & $\mathrm{NaN}$ & -8.239 & -8.455 \\
\hline 56.50 & 873.9 & 7.087E-04 & 1.180E-04 & $\mathrm{NaN}$ & $\mathrm{NaN}$ \\
\hline 57.00 & 870.8 & $6.588 \mathrm{E}-04$ & 1.123E-04 & $\mathrm{NaN}$ & $\mathrm{NaN}$ \\
\hline 57.49 & 867.6 & $6.651 \mathrm{E}-04$ & $1.151 \mathrm{E}-04$ & $\mathrm{NaN}$ & $\mathrm{NaN}$ \\
\hline 57.98 & 864.4 & $\mathrm{NaN}$ & $\mathrm{NaN}$ & -9.035 & -8.535 \\
\hline 58.48 & 861.1 & 6.641E-04 & 1.134E-04 & $\mathrm{NaN}$ & $\mathrm{NaN}$ \\
\hline 59.00 & 857.5 & $7.260 \mathrm{E}-04$ & 1.103E-04 & $\mathrm{NaN}$ & $\mathrm{NaN}$ \\
\hline 59.80 & 851.8 & 7.259E-04 & 1.063E-04 & $\mathrm{NaN}$ & $\mathrm{NaN}$ \\
\hline 60.29 & 848.3 & 7.375E-04 & $1.188 \mathrm{E}-04$ & $\mathrm{NaN}$ & $\mathrm{NaN}$ \\
\hline 60.80 & 844.5 & $\mathrm{NaN}$ & $\mathrm{NaN}$ & -8.311 & -8.17 \\
\hline 61.00 & 843.1 & 7.174E-04 & 1.220E-04 & $\mathrm{NaN}$ & $\mathrm{NaN}$ \\
\hline 61.31 & 840.8 & 7.156E-04 & 1.239E-04 & $\mathrm{NaN}$ & $\mathrm{NaN}$ \\
\hline 61.92 & 836.5 & 6.910E-04 & 1.046E-04 & $\mathrm{NaN}$ & $\mathrm{NaN}$ \\
\hline 62.40 & 833.2 & 8.097E-04 & 9.672E-05 & $\mathrm{NaN}$ & $\mathrm{NaN}$ \\
\hline 62.88 & 830.0 & $\mathrm{NaN}$ & $\mathrm{NaN}$ & -7.872 & -7.994 \\
\hline 63.00 & 829.1 & $8.262 \mathrm{E}-04$ & 9.834E-05 & $\mathrm{NaN}$ & $\mathrm{NaN}$ \\
\hline 63.38 & 826.7 & 7.698E-04 & 1.059E-04 & $\mathrm{NaN}$ & $\mathrm{NaN}$ \\
\hline 64.03 & 822.5 & 8.735E-04 & 1.186E-04 & $\mathrm{NaN}$ & $\mathrm{NaN}$ \\
\hline 64.55 & 819.1 & 8.426E-04 & 1.262E-04 & $\mathrm{NaN}$ & $\mathrm{NaN}$ \\
\hline 65.00 & 816.2 & $\mathrm{NaN}$ & $\mathrm{NaN}$ & -6.144 & -7.964 \\
\hline 65.05 & 815.9 & 8.584E-04 & 1.315E-04 & $\mathrm{NaN}$ & $\mathrm{NaN}$ \\
\hline 65.59 & 812.4 & 8.167E-04 & 1.435E-04 & $\mathrm{NaN}$ & $\mathrm{NaN}$ \\
\hline 66.08 & 809.2 & 7.481E-04 & $1.498 \mathrm{E}-04$ & $\mathrm{NaN}$ & $\mathrm{NaN}$ \\
\hline 66.59 & 806.0 & $\mathrm{NaN}$ & $\mathrm{NaN}$ & -6.121 & -8.152 \\
\hline 67.00 & 803.4 & 7.813E-04 & $1.490 \mathrm{E}-04$ & $\mathrm{NaN}$ & $\mathrm{NaN}$ \\
\hline 67.10 & 802.7 & 7.310E-04 & 1.500E-04 & $\mathrm{NaN}$ & $\mathrm{NaN}$ \\
\hline 67.62 & 799.4 & 7.293E-04 & 1.487E-04 & $\mathrm{NaN}$ & $\mathrm{NaN}$ \\
\hline 68.11 & 796.3 & 7.401E-04 & 1.468E-04 & $\mathrm{NaN}$ & $\mathrm{NaN}$ \\
\hline 68.62 & 793.0 & $6.211 \mathrm{E}-04$ & 1.389E-04 & $\mathrm{NaN}$ & NaN \\
\hline 69.00 & 790.6 & $\mathrm{NaN}$ & $\mathrm{NaN}$ & -7.766 & -8.462 \\
\hline 69.13 & 789.8 & 6.380E-04 & 1.353E-04 & $\mathrm{NaN}$ & $\mathrm{NaN}$ \\
\hline 69.63 & 786.5 & $6.471 \mathrm{E}-04$ & 1.347E-04 & $\mathrm{NaN}$ & $\mathrm{NaN}$ \\
\hline 70.13 & 783.3 & $6.458 \mathrm{E}-04$ & 1.337E-04 & $\mathrm{NaN}$ & $\mathrm{NaN}$ \\
\hline 70.64 & 779.9 & 6.836E-04 & $1.300 \mathrm{E}-04$ & $\mathrm{NaN}$ & $\mathrm{NaN}$ \\
\hline 71.00 & 777.5 & $\mathrm{NaN}$ & $\mathrm{NaN}$ & -8.321 & -8.492 \\
\hline 71.16 & 776.4 & 6.719E-04 & 1.283E-04 & $\mathrm{NaN}$ & $\mathrm{NaN}$ \\
\hline 71.68 & 772.9 & 6.507E-04 & 1.314E-04 & $\mathrm{NaN}$ & $\mathrm{NaN}$ \\
\hline 72.17 & 769.7 & 7.028E-04 & 1.199E-04 & $\mathrm{NaN}$ & $\mathrm{NaN}$ \\
\hline 72.68 & 766.4 & 6.607E-04 & $1.248 \mathrm{E}-04$ & $\mathrm{NaN}$ & $\mathrm{NaN}$ \\
\hline
\end{tabular}




\begin{tabular}{|c|c|c|c|c|c|}
\hline 73.00 & 764.2 & $\mathrm{NaN}$ & $\mathrm{NaN}$ & -8.086 & -8.265 \\
\hline 73.18 & 762.9 & 7.142E-04 & 1.135E-04 & $\mathrm{NaN}$ & $\mathrm{NaN}$ \\
\hline 73.70 & 759.3 & 7.213E-04 & 1.155E-04 & $\mathrm{NaN}$ & $\mathrm{NaN}$ \\
\hline 74.19 & 755.9 & 7.027E-04 & 1.150E-04 & $\mathrm{NaN}$ & $\mathrm{NaN}$ \\
\hline 74.71 & 752.3 & 7.170E-04 & 1.092E-04 & $\mathrm{NaN}$ & $\mathrm{NaN}$ \\
\hline 75.00 & 750.3 & $\mathrm{NaN}$ & $\mathrm{NaN}$ & -8.943 & -8.523 \\
\hline 75.22 & 748.7 & 7.033E-04 & 1.047E-04 & $\mathrm{NaN}$ & $\mathrm{NaN}$ \\
\hline 75.74 & 745.1 & 6.991E-04 & 1.057E-04 & $\mathrm{NaN}$ & $\mathrm{NaN}$ \\
\hline 76.22 & 741.6 & 7.272E-04 & 1.027E-04 & $\mathrm{NaN}$ & $\mathrm{NaN}$ \\
\hline 76.74 & 737.9 & 7.245E-04 & 1.087E-04 & $\mathrm{NaN}$ & $\mathrm{NaN}$ \\
\hline 77.00 & 735.8 & $\mathrm{NaN}$ & $\mathrm{NaN}$ & -8.737 & -8.532 \\
\hline 77.25 & 734.0 & 6.981E-04 & 1.088E-04 & $\mathrm{NaN}$ & $\mathrm{NaN}$ \\
\hline 77.76 & 730.2 & 7.606E-04 & 1.043E-04 & $\mathrm{NaN}$ & $\mathrm{NaN}$ \\
\hline 78.25 & 726.4 & 7.989E-04 & 1.031E-04 & $\mathrm{NaN}$ & $\mathrm{NaN}$ \\
\hline 78.77 & 722.4 & 7.927E-04 & 1.033E-04 & $\mathrm{NaN}$ & $\mathrm{NaN}$ \\
\hline 79.00 & 720.6 & $\mathrm{NaN}$ & $\mathrm{NaN}$ & -7.982 & -8.31 \\
\hline 79.29 & 718.3 & 7.550E-04 & 1.147E-04 & $\mathrm{NaN}$ & $\mathrm{NaN}$ \\
\hline 79.79 & 714.3 & 8.530E-04 & 1.123E-04 & $\mathrm{NaN}$ & $\mathrm{NaN}$ \\
\hline 80.29 & 710.3 & 1.054E-03 & 1.109E-04 & $\mathrm{NaN}$ & $\mathrm{NaN}$ \\
\hline 80.80 & 705.9 & 1.151E-03 & 1.173E-04 & $\mathrm{NaN}$ & $\mathrm{NaN}$ \\
\hline 81.00 & 704.1 & $\mathrm{NaN}$ & $\mathrm{NaN}$ & -6.79 & -8.00 \\
\hline 81.30 & 701.3 & $1.173 \mathrm{E}-03$ & 1.244E-04 & $\mathrm{NaN}$ & $\mathrm{NaN}$ \\
\hline 81.56 & 698.7 & 8.939E-04 & 1.312E-04 & $\mathrm{NaN}$ & $\mathrm{NaN}$ \\
\hline 82.34 & 690.9 & 7.929E-04 & $1.288 \mathrm{E}-04$ & $\mathrm{NaN}$ & $\mathrm{NaN}$ \\
\hline 82.83 & 685.6 & 7.444E-04 & 1.306E-04 & $\mathrm{NaN}$ & $\mathrm{NaN}$ \\
\hline 83.00 & 683.8 & $\mathrm{NaN}$ & $\mathrm{NaN}$ & -7.746 & -7.875 \\
\hline 83.34 & 679.9 & 7.227E-04 & 1.315E-04 & $\mathrm{NaN}$ & $\mathrm{NaN}$ \\
\hline 83.84 & 674.2 & 7.000E-04 & 1.319E-04 & $\mathrm{NaN}$ & $\mathrm{NaN}$ \\
\hline 84.36 & 668.1 & 6.920E-04 & 1.357E-04 & $\mathrm{NaN}$ & $\mathrm{NaN}$ \\
\hline 84.86 & 662.1 & $6.770 \mathrm{E}-04$ & 1.381E-04 & $\mathrm{NaN}$ & $\mathrm{NaN}$ \\
\hline 85.00 & 660.4 & 6.270E-04 & $\mathrm{NaN}$ & -8.155 & -8.212 \\
\hline 85.36 & 656.0 & 7.214E-04 & $1.345 \mathrm{E}-04$ & $\mathrm{NaN}$ & $\mathrm{NaN}$ \\
\hline 85.89 & 649.4 & 7.180E-04 & 1.455E-04 & $\mathrm{NaN}$ & $\mathrm{NaN}$ \\
\hline 86.39 & 643.1 & 6.997E-04 & 1.410E-04 & $\mathrm{NaN}$ & $\mathrm{NaN}$ \\
\hline 86.91 & 636.7 & $6.831 \mathrm{E}-04$ & 1.423E-04 & $\mathrm{NaN}$ & $\mathrm{NaN}$ \\
\hline 87.00 & 635.5 & 5.780E-04 & $\mathrm{NaN}$ & -7.658 & -8.193 \\
\hline 87.40 & 630.6 & 6.989E-04 & 1.384E-04 & $\mathrm{NaN}$ & $\mathrm{NaN}$ \\
\hline 87.92 & 624.0 & $6.841 \mathrm{E}-04$ & 1.408E-04 & $\mathrm{NaN}$ & $\mathrm{NaN}$ \\
\hline 88.43 & 617.7 & $7.141 \mathrm{E}-04$ & 1.419E-04 & $\mathrm{NaN}$ & $\mathrm{NaN}$ \\
\hline
\end{tabular}




\begin{tabular}{|c|c|c|c|c|c|}
\hline 88.94 & 611.5 & 7.606E-04 & 1.261E-04 & $\mathrm{NaN}$ & $\mathrm{NaN}$ \\
\hline 89.00 & 610.7 & 7.663E-04 & $\mathrm{NaN}$ & -7.942 & -8.241 \\
\hline 89.44 & 605.4 & 8.240E-04 & 1.176E-04 & $\mathrm{NaN}$ & $\mathrm{NaN}$ \\
\hline 89.95 & 599.3 & 7.275E-04 & 1.112E-04 & $\mathrm{NaN}$ & $\mathrm{NaN}$ \\
\hline 90.46 & 593.3 & 7.661E-04 & 1.081E-04 & $\mathrm{NaN}$ & $\mathrm{NaN}$ \\
\hline 90.97 & 587.5 & 9.588E-04 & 1.081E-04 & $\mathrm{NaN}$ & $\mathrm{NaN}$ \\
\hline 91.00 & 587.2 & 7.742E-04 & $\mathrm{NaN}$ & -8.455 & -8.267 \\
\hline 91.47 & 582.0 & 9.996E-04 & 1.096E-04 & $\mathrm{NaN}$ & $\mathrm{NaN}$ \\
\hline 93.00 & 566.4 & 1.430E-03 & 1.074E-04 & $\mathrm{NaN}$ & $\mathrm{NaN}$ \\
\hline 95.50 & 546.8 & 1.372E-03 & 1.082E-04 & $\mathrm{NaN}$ & $\mathrm{NaN}$ \\
\hline 98.00 & 536.8 & 1.277E-03 & 1.116E-04 & $\mathrm{NaN}$ & $\mathrm{NaN}$ \\
\hline 100.50 & 533.1 & 1.210E-03 & $\mathrm{NaN}$ & -5.226 & -7.431 \\
\hline 103.00 & 529.9 & 1.206E-03 & 1.205E-04 & $\mathrm{NaN}$ & $\mathrm{NaN}$ \\
\hline 105.50 & 527.0 & 1.014E-03 & 1.017E-04 & -6.48 & -8.653 \\
\hline 108.00 & 524.8 & 8.491E-04 & 9.369E-05 & -7.146 & -7.987 \\
\hline 110.00 & 523.1 & 7.744E-04 & 9.119E-05 & -7.955 & -8.196 \\
\hline 112.00 & 521.6 & 7.927E-04 & 8.875E-05 & -7.903 & -8.172 \\
\hline 114.00 & 520.2 & 7.821E-04 & 8.699E-05 & -7.944 & -8.138 \\
\hline 116.00 & 519.0 & 7.890E-04 & 8.571E-05 & -8.104 & -8.219 \\
\hline 118.00 & 517.8 & $8.234 \mathrm{E}-04$ & 7.937E-05 & -8.086 & -8.209 \\
\hline 120.00 & 516.8 & 8.630E-04 & 7.884E-05 & -7.84 & -8.185 \\
\hline 122.00 & 515.7 & 8.984E-04 & 7.846E-05 & -7.126 & -7.919 \\
\hline 123.50 & 514.9 & 8.810E-04 & 8.041E-05 & -7.400 & -7.982 \\
\hline 124.50 & 514.4 & 8.562E-04 & 7.772E-05 & -7.856 & -8.142 \\
\hline 126.00 & 513.5 & 8.455E-04 & 7.734E-05 & -8.024 & -8.105 \\
\hline 128.00 & 512.3 & 9.075E-04 & 8.229E-05 & -7.058 & -7.83 \\
\hline 130.00 & 511.0 & 8.344E-04 & 7.961E-05 & -8.023 & -8.122 \\
\hline 132.00 & 509.5 & 7.596E-04 & 7.714E-05 & -8.546 & -8.284 \\
\hline 134.50 & 507.5 & 7.495E-04 & 7.791E-05 & -8.584 & -8.192 \\
\hline 137.00 & 505.4 & 8.238E-04 & 7.571E-05 & -8.198 & -8.15 \\
\hline 138.50 & 504.2 & 9.268E-04 & 8.585E-05 & -6.612 & -7.703 \\
\hline 140.00 & 503.0 & 8.819E-04 & 8.887E-05 & -7.234 & -7.93 \\
\hline 141.50 & 501.8 & 7.698E-04 & 8.955E-05 & -8.136 & -8.147 \\
\hline 142.50 & 501.1 & 7.314E-04 & 8.590E-05 & -8.398 & -8.353 \\
\hline 144.50 & 499.5 & 1.220E-03 & 8.624E-05 & -6.546 & -7.734 \\
\hline 146.50 & 497.9 & 1.164E-03 & $1.008 \mathrm{E}-04$ & -6.168 & -7.685 \\
\hline 148.00 & 496.7 & 1.060E-03 & 1.026E-04 & -6.605 & -7.788 \\
\hline 150.00 & 495.0 & 1.109E-03 & 1.127E-04 & -5.904 & -7.739 \\
\hline
\end{tabular}




\begin{tabular}{|c|c|c|c|c|c|}
\hline 152.00 & 493.3 & 1.041E-03 & 1.101E-04 & -6.348 & -7.875 \\
\hline 153.50 & 491.9 & 8.881E-04 & 1.184E-04 & -6.58 & -7.896 \\
\hline 154.50 & 491.1 & 8.256E-04 & 1.132E-04 & -7.751 & -8.278 \\
\hline 156.00 & 489.6 & 8.013E-04 & 9.667E-05 & -8.696 & -8.586 \\
\hline 158.50 & 487.1 & 7.744E-04 & 1.030E-04 & -8.626 & -8.486 \\
\hline 161.00 & 484.3 & 8.230E-04 & 1.032E-04 & -8.655 & -8.519 \\
\hline 162.50 & 482.5 & $8.133 \mathrm{E}-04$ & $9.510 \mathrm{E}-05$ & -8.576 & -8.465 \\
\hline 164.00 & 480.6 & 7.906E-04 & 8.172E-05 & -9.25 & -8.518 \\
\hline 166.50 & 477.2 & 8.787E-04 & 9.169E-05 & -7.984 & -8.124 \\
\hline 169.50 & 472.7 & 1.047E-03 & 1.046E-04 & -6.616 & -7.828 \\
\hline 171.50 & 469.1 & 9.984E-04 & 1.056E-04 & -7.114 & -7.95 \\
\hline 173.00 & 465.4 & 9.967E-04 & 1.102E-04 & -6.81 & -7.908 \\
\hline 175.00 & 459.5 & 8.999E-04 & $1.088 \mathrm{E}-04$ & -7.326 & -8.087 \\
\hline 176.00 & 456.1 & 8.734E-04 & 1.039E-04 & -8.10 & -8.168 \\
\hline 177.02 & 452.6 & 9.297E-04 & 8.809E-05 & -7.648 & -8.013 \\
\hline 177.52 & 450.7 & 9.213E-04 & $9.318 \mathrm{E}-05$ & -7.944 & -8.073 \\
\hline 178.03 & 448.8 & 9.442E-04 & 8.741E-05 & -7.882 & -8.067 \\
\hline 178.54 & 446.8 & 9.184E-04 & 8.559E-05 & -8.210 & -8.281 \\
\hline 179.05 & 444.8 & 8.627E-04 & 1.082E-04 & $\mathrm{NaN}$ & $\mathrm{NaN}$ \\
\hline 179.55 & 442.9 & 8.928E-04 & $1.225 \mathrm{E}-04$ & $\mathrm{NaN}$ & $\mathrm{NaN}$ \\
\hline 180.06 & 440.9 & $9.218 \mathrm{E}-04$ & 1.486E-04 & $\mathrm{NaN}$ & $\mathrm{NaN}$ \\
\hline 180.57 & 438.9 & 9.104E-04 & 1.116E-04 & $\mathrm{NaN}$ & $\mathrm{NaN}$ \\
\hline 181.08 & 436.8 & 8.798E-04 & 1.606E-04 & $\mathrm{NaN}$ & $\mathrm{NaN}$ \\
\hline 182.09 & 432.7 & 7.965E-04 & 1.390E-04 & $\mathrm{NaN}$ & $\mathrm{NaN}$ \\
\hline 182.60 & 430.6 & 7.995E-04 & 1.239E-04 & $\mathrm{NaN}$ & $\mathrm{NaN}$ \\
\hline 183.11 & 428.6 & 7.468E-04 & $1.248 \mathrm{E}-04$ & $\mathrm{NaN}$ & $\mathrm{NaN}$ \\
\hline 183.61 & 426.6 & 7.340E-04 & 1.351E-04 & $\mathrm{NaN}$ & $\mathrm{NaN}$ \\
\hline 184.12 & 424.5 & 7.292E-04 & $1.458 \mathrm{E}-04$ & $\mathrm{NaN}$ & $\mathrm{NaN}$ \\
\hline 184.63 & 422.6 & 7.508E-04 & $1.540 \mathrm{E}-04$ & $\mathrm{NaN}$ & $\mathrm{NaN}$ \\
\hline 185.14 & 420.6 & 6.449E-04 & 1.310E-04 & $\mathrm{NaN}$ & $\mathrm{NaN}$ \\
\hline 185.64 & 418.7 & $6.133 \mathrm{E}-04$ & $1.440 \mathrm{E}-04$ & $\mathrm{NaN}$ & $\mathrm{NaN}$ \\
\hline 186.15 & 416.9 & 6.039E-04 & 1.360E-04 & $\mathrm{NaN}$ & $\mathrm{NaN}$ \\
\hline 186.66 & 415.0 & $6.828 \mathrm{E}-04$ & 1.410E-04 & $\mathrm{NaN}$ & $\mathrm{NaN}$ \\
\hline 189.00 & 407.4 & 6.892E-04 & 1.410E-04 & $\mathrm{NaN}$ & $\mathrm{NaN}$ \\
\hline 189.25 & 406.7 & 5.878E-04 & 1.370E-04 & $\mathrm{NaN}$ & $\mathrm{NaN}$ \\
\hline 191.00 & 402.0 & 7.939E-04 & 1.410E-04 & $\mathrm{NaN}$ & $\mathrm{NaN}$ \\
\hline 193.00 & 397.3 & 7.889E-04 & 1.550E-04 & $\mathrm{NaN}$ & $\mathrm{NaN}$ \\
\hline 195.00 & 392.6 & 7.973E-04 & 1.570E-04 & $\mathrm{NaN}$ & $\mathrm{NaN}$ \\
\hline 197.00 & 388.1 & 7.569E-04 & 1.490E-04 & $\mathrm{NaN}$ & $\mathrm{NaN}$ \\
\hline
\end{tabular}




\begin{tabular}{|c|c|c|c|c|c|}
\hline 199.00 & 383.6 & 7.648E-04 & 1.620E-04 & $\mathrm{NaN}$ & $\mathrm{NaN}$ \\
\hline 201.00 & 379.3 & 8.031E-04 & 1.540E-04 & $\mathrm{NaN}$ & $\mathrm{NaN}$ \\
\hline 202.50 & 376.1 & 1.054E-03 & 7.450E-05 & $\mathrm{NaN}$ & $\mathrm{NaN}$ \\
\hline 204.50 & 371.9 & 1.054E-03 & 7.453E-05 & -6.579 & -7.837 \\
\hline 207.00 & 366.9 & 1.100E-03 & 7.537E-05 & $\mathrm{NaN}$ & $\mathrm{NaN}$ \\
\hline 209.00 & 362.9 & 1.118E-03 & 7.840E-05 & -6.076 & -7.647 \\
\hline 211.00 & 359.1 & 1.382E-03 & 8.620E-05 & -4.396 & -7.204 \\
\hline 213.00 & 355.4 & 1.190E-03 & 8.320E-05 & $\mathrm{NaN}$ & $\mathrm{NaN}$ \\
\hline 215.00 & 351.8 & $1.188 \mathrm{E}-03$ & 8.320E-05 & -5.291 & -7.291 \\
\hline 217.50 & 347.4 & 1.068E-03 & 8.860E-05 & -6.161 & -7.66 \\
\hline 220.00 & 343.1 & 9.733E-04 & $9.230 \mathrm{E}-05$ & -6.827 & -7.776 \\
\hline 222.00 & 339.9 & 9.515E-04 & 9.770E-05 & -6.575 & -7.828 \\
\hline 224.50 & 336.0 & 9.167E-04 & 1.014E-04 & -6.363 & -7.696 \\
\hline 227.00 & 332.3 & 9.946E-04 & 9.370E-05 & -6.00 & -7.589 \\
\hline 229.00 & 329.5 & 9.993E-04 & 1.054E-04 & -6.01 & -7.583 \\
\hline 231.50 & 326.1 & 8.760E-04 & 9.910E-05 & -7.479 & -8.034 \\
\hline 234.50 & 322.2 & 8.507E-04 & $9.460 \mathrm{E}-05$ & -7.713 & -8.009 \\
\hline 237.00 & 319.3 & 8.402E-04 & 1.005E-04 & -7.384 & -7.964 \\
\hline 239.00 & 317.0 & 8.908E-04 & 8.530E-05 & -8.074 & -8.135 \\
\hline 241.00 & 314.8 & 8.359E-04 & 9.610E-05 & -8.112 & -8.213 \\
\hline 243.00 & 312.8 & 8.020E-04 & 9.390E-05 & -8.146 & -8.226 \\
\hline 245.00 & 310.7 & 7.812E-04 & 8.910E-05 & -9.056 & -8.432 \\
\hline 247.00 & 308.7 & 8.357E-04 & 9.310E-05 & -8.374 & -8.264 \\
\hline 249.00 & 306.8 & 8.879E-04 & 8.520E-05 & -8.322 & -8.156 \\
\hline 251.00 & 304.9 & 8.423E-04 & 8.030E-05 & -8.772 & -8.304 \\
\hline 253.00 & 303.0 & $9.166 \mathrm{E}-04$ & 7.700E-05 & -8.426 & -8.247 \\
\hline 255.00 & 301.2 & 9.583E-04 & 7.430E-05 & -7.95 & -8.024 \\
\hline 257.00 & 299.5 & 9.633E-04 & 7.340E-05 & -7.937 & -7.875 \\
\hline 259.00 & 297.9 & 9.792E-04 & 7.360E-05 & -7.621 & -7.906 \\
\hline 261.50 & 296.0 & 1.070E-03 & 7.330E-05 & -7.135 & -7.722 \\
\hline 264.00 & 294.3 & 1.084E-03 & 7.450E-05 & -6.95 & -7.695 \\
\hline 266.00 & 293.1 & 1.029E-03 & 7.630E-05 & -7.19 & -7.744 \\
\hline 268.00 & 291.9 & 1.102E-03 & 7.300E-05 & -6.687 & -7.655 \\
\hline 270.00 & 290.9 & 1.043E-03 & 7.230E-05 & -7.501 & -7.797 \\
\hline 272.00 & 290.0 & 1.019E-03 & 7.180E-05 & -7.715 & -7.945 \\
\hline 274.00 & 289.2 & 1.049E-03 & 7.520E-05 & -7.611 & -7.939 \\
\hline 276.00 & 288.5 & $1.008 \mathrm{E}-03$ & 7.040E-05 & -7.994 & -8.046 \\
\hline
\end{tabular}




\title{
Chapter 4: A novel speleothem-derived record of drying during the 8.2 ka event in northern Mexico
}

\begin{abstract}
The $8.2 \mathrm{ka}$ event was a rapid discharge of meltwater from a proglacial lake associated with the Laurentide Ice Sheet. The pulse of water may have weakened Atlantic Meridional Overturning Circulation (AMOC) by $10-25 \%$, so it serves as a potential analog for weakening AMOC under anthropogenic climate change. In this chapter, I present the first decadal-scale resolution record of northern Mexican hydroclimate during the 8.2 ka event, using a speleothem from Rioverde, San Luis Potosi, Mexico. We show stable isotope and trace element to calcium ratio data from this precisely-dated stalagmite, which grew from $21.3 \pm 0.26$ to $11.8 \pm 0.05 \mathrm{ka} \mathrm{BP}$, followed by a hiatus, then a second growth period from $8.89 \pm 0.05$ to $6.9 \pm 0.13 \mathrm{ka} \mathrm{BP}$ (the focus of this work). There is a statistically significant increase in mean $\delta^{13} \mathrm{C}$ and $\mathrm{Sr} / \mathrm{Ca}$ from before the $8.2 \mathrm{ka}$ event to after $8.0 \mathrm{ka}$, and a slight (but not statistically significant) increase in $\mathrm{Mg} / \mathrm{Ca}$. There is a 200-year-long period of elevated $\delta^{18} \mathrm{O}$ from 8.2 to $8.0 \mathrm{ka}$, followed by a return to pre-event values. We interpret this as decreased precipitation amount $\left(\delta^{18} \mathrm{O}\right)$ that significantly impacted soil moisture and vegetation $\left(\delta^{13} \mathrm{C}, \mathrm{Mg} / \mathrm{Ca}, \mathrm{Sr} / \mathrm{Ca}\right)$ to the point where recovery to pre-event conditions was impossible for hundreds of years. This work demonstrates that northern Mexico is sensitive to weakening AMOC, suggesting that increased drought resilience and improved water management practices will be important in the coming decades and centuries to prevent water scarcity.
\end{abstract}

\section{Introduction}

As in Chapter 3, this Chapter will present a new climate record from northeastern Mexico, an understudied region of Mexico. This Chapter examines a site that is east of Cueva de la Puente and the city of San Luis Potosi (Chapter 3), near Rioverde, San Luis Potosi, Mexico. Both sites are part of the Mexican arid zone, which is simultaneously experiencing increasing water scarcity and a rapidly growing population (Martinez et al., 2010). The two sites are not identical, however, and they have some key differences in weather, climate, and water use.

There are two types of freshwater in the Rioverde Valley: to the North, there is brackish, undrinkable water with dissolved calcium sulfate, and in the South, there is potable water that can be used for crop irrigation (Aguilar-Ortega et al., 2010). In both regions, the water is distributed in a deep calcareous aquifer and a shallower alluvial aquifer (Aguilar-Ortega et al., 2010). Due to high demand for the useable water from the southern region, there is an imbalance between recharge and extraction. Therefore, the shallow aquifer is vulnerable to being emptied completely, and deep wells could begin to exploit the calcareous aquifer (Aguilar-Ortega et al., 
2010). Irrigation systems can only use the southern freshwater, so agriculture is dependent on sufficient water in the aquifers. These pressures will only worsen under anthropogenic climate change (Scheff et al., 2017; Williams et al., 2020)

One of many controls on precipitation and moisture in the Mexican arid region is the Atlantic Meridional Overturning Circulation (AMOC). Some data suggest that AMOC is at its weakest state since the Little Ice Age, and as anthropogenic warming progresses, AMOC is projected to weaken even further (Thornalley et al., 2018). In order to best prepare for the effects of decreased AMOC strength, we need to know exactly what those effects will be. The paleoclimate record provides some previous examples of AMOC weakening, which act as imperfect analogues for the present and future. Two such events include the so-called $8.2 \mathrm{ka}$ event and the Younger Dryas (YD). The $8.2 \mathrm{ka}$ event ( $\mathrm{ka}=$ thousand years before present) is particularly interesting in that it was an extreme event with a very short timescale, which is rarely captured in the geological record, and that it occurred during an interglacial period. While the $8.2 \mathrm{ka}$ event has been studied extensively in some regions, such as Europe and the Arctic, there are still several questions that remain. For instance, at the most basic level, how did the Mexican arid region respond to a weakened AMOC during the $8.2 \mathrm{ka}$ ? Weakened AMOC can yield decreased Atlantic SSTs and increased winds, which both contribute to drying, during major events like Heinrich Stadials (Wright et al., in prep), but the 8.2 ka event was different. To our knowledge, there is no existing record of hydroclimate in northern Mexico that has a high enough resolution and low enough dating uncertainties to clearly show how the region responded to the $8.2 \mathrm{ka}$ event. In this work, we present that record, from a stalagmite that grew in San Luis Potosí, Mexico.

\subsection{The 8.2 ka event}

The 8.2 ka event occurred because of the catastrophic draining of Lakes Agassiz and Ojibway, proglacial lakes associated with the Laurentide Ice Sheet. The huge freshwater outflow through the Hudson Strait weakened AMOC by $10-25 \%$, according to multiple climate simulations (Morrill, Legrande, et al., 2013), and induced approximately 160 years of $1-3{ }^{\circ} \mathrm{C}$ cooling in the Northern Hemisphere (Matero et al., 2017; Thomas et al., 2007). It's also possible that there was a significant dome or saddle collapse that induced flooding or atmospheric changes across North America (Matero et al., 2017). Early estimates found cooling of up to 4-8 ${ }^{\circ} \mathrm{C}$ in central Greenland (Alley et al., 1997), but more recent work has adjusted that estimate to 3- 
$4{ }^{\circ} \mathrm{C}$ (Kobashi et al., 2007). Though there were some regions with long-lasting impacts, the freshwater pulse and associated cooling was so short that the entire event is within the age model uncertainty of many records, or poor resolution renders it difficult to perform robust analyses.

Despite its brevity, this event has been studied for decades. Freshwater input in the North Atlantic Ocean decreases sea surface temperature (SST) because cross-equatorial northward heat transport (such as the warm Gulf Stream) slows down (McGee et al., 2014; Wong et al., 2015). In addition, there is stronger wind, including northeasterly winds that bring cold, dry air into the Caribbean Low-Level Jet (CLLJ), over Mexico, and into the Pacific (Wong et al., 2015). In many ways, the $8.2 \mathrm{ka}$ event was similar to the YD or a Heinrich Stadial, but on a smaller and shorter scale, as they were all driven by substantial freshwater input to the Atlantic (Ebbesen \& Hald, 2004; Kendall et al., 2008; Oster et al., 2017; Teller et al., 2002). North Atlantic SSTs cooled by $6-8{ }^{\circ} \mathrm{C}$ after the YD (Ebbesen \& Hald, 2004), but the 8.2 ka event was not as dramatic: the mean annual temperature depression outside of Greenland was $1{ }^{\circ} \mathrm{C}$ (Morrill, Anderson, et al., 2013). Based on Heinrich Stadials and the YD, we know that the overall impact of freshwater events like this is reduced moisture flux over most of northern Mexico (Roy et al., 2016; Wright et al., in prep.) and southward displacement of the ITCZ due to cooler SST (Lachniet et al., 2013; Vellinga \& Wood, 2002). Furthermore, a proxy data synthesis noted that New Mexico, USA was wetter during the $8.2 \mathrm{ka}$ event, while southern Mexico and the rest of Central America was drier, but there is a large spatial data gap between those two regions (Morrill, Anderson, et al., 2013). In this work, we will investigate how the 8.2 ka event impacted precipitation in northern Mexico to fill in that gap in knowledge.

Due to the North Atlantic origin of the $8.2 \mathrm{ka}$ event, its impacts have been studied at length Europe and Canada. Ice core records estimate the duration of the cool anomaly as precisely 150160 years (Kobashi et al., 2007; Morrill, Anderson, et al., 2013; Thomas et al., 2007) but temperature was not the only significant change. For example, pollen studies have shown that there were major vegetation changes in Norway and central Europe (Switzerland and Germany) after the $8.2 \mathrm{ka}$ event, with entire forest ecosystems rearranging themselves within decades (Paus, 2009; Tinner \& Lotter, 2001). There were also longer-lasting effects that continued long after temperatures returned to pre-event levels; in Norway, the vegetation effects lasted for 400 years after the event (Paus, 2009). In terms of precipitation, however, the consequences of the 8.2 ka event are more spatially variable. For instance, Canadian proxy records reveal no 
discernable change in moisture during the 8.2 ka event, and northern European datasets show wetter conditions even as central European records demonstrated clear drying (Morrill, Anderson, et al., 2013).

\subsubsection{North America during the $8.2 \mathrm{ka}$}

While there are no existing data on northern Mexican responses to the $8.2 \mathrm{ka}$ event, there have been several investigations into other regions in or near North America. For example, a speleothem record in California recorded more variable $\delta^{13} \mathrm{C}$ and lower trace element to calcium ratios during the $8.2 \mathrm{ka}$ event, interpreted as increased winter storms and wetter conditions in the Pacific (Oster et al., 2017). Similarly, a speleothem from the Guadalupe Mountains, New Mexico, USA showed a negative $\delta^{18} \mathrm{O}$ anomaly (wetter) compared to early Holocene values, and a guano core indicated that the Grand Canyon, Arizona, USA saw more storms (Asmerom et al., 2007; Wurster et al., 2008). In Nevada, speleothems recorded a wet period between 10.3 and 8.2 ka, followed by a long shift to drier conditions after the event (Steponaitis et al., 2015). Further to the south, a speleothem from Cueva del Diablo completely stopped growing from 8.2 to 8.0 ka, which was understood as severe drying (Bernal et al., 2011). Similarly, pollen in a lake sediment core from western central Mexico (west of Cueva del Diablo and Mexico City) showed a significant change in dominant vegetation at $8.2 \mathrm{ka}$, with a decrease in alder species (LozanoGarcía et al., 2013); the authors attributed the change to colder, drier climate, but the proxies in the sediment core were not directly recording precipitation changes (Lozano-García et al., 2013). Lachniet et al. (2013) also found drying during the $8.2 \mathrm{ka}$, but the drying trend began earlier than the 8.2 ka event.

However, in Nevada, the 8.2 ka event was just the beginning of a much longer local drying trend, which continued through the end of the speleothem record at $3.8 \mathrm{ka}$ (Steponaitis et al., 2015). Steponaitis et al. (2015) suggest the wet early Holocene was controlled by ice remaining from the Laurentide ice sheet, referred to as the 8.5 ka remnant, which increased winter precipitation in the western US. Once that remnant sheet collapsed over Hudson Bay, it no longer dammed Lakes Agassiz and Ojibway, yielding (or contributing to) the rapid glacial lake outflow that characterizes the $8.2 \mathrm{ka}$ event (Steponaitis et al., 2015). Another study links drying in the Great Basin to decreased Arctic ice extent (Lachniet et al., 2020), which was low from $\sim 9.0$ to $6.0 \mathrm{ka}$ (Stranne et al., 2014). 
Because northern Mexico is situated between locations that dried (southern Mexico) and regions that received more storms and precipitation (California, Arizona), it remains unclear how precipitation in much of Mexico - including the parts most vulnerable to decreasing precipitation - responded to the $8.2 \mathrm{ka}$ event.

\subsubsection{Atlantic Ocean and Gulf of Mexico before, during, and after the $8.2 \mathrm{ka}$}

A Gulf of Mexico (GOM) sediment core (Orca Basin; core MD02-2550) showed SST cooling of $\sim 1^{\circ} \mathrm{C}$ from before the $8.2 \mathrm{ka}$ to $8 \mathrm{ka}$, based on $\mathrm{Mg} / \mathrm{Ca}$ paleothermometry (LoDico et al., 2006). The cooling was temporary, and was superimposed on an overall gradual warming trend from 9.4 to $7 \mathrm{ka}$. Therefore, the authors also reconstructed $\delta^{18} \mathrm{O}_{\mathrm{GOM}}$ from $\delta^{18} \mathrm{O}_{\text {foram }}$ to better understand how the GOM responded to the $8.2 \mathrm{ka}$ event. Sea level changed significantly from the early Holocene through the $8.2 \mathrm{ka}$, so the $\delta^{18} \mathrm{O}_{\text {foram }}$ values were ice volume-corrected; for reference, sea level rose by $15 \mathrm{~m}$ from 9.5 to $7.5 \mathrm{ka}$ BP in Chesapeake Bay (Cronin et al., 2007). LoDico et al. (2006) further accounted for temperature shifts using $\mathrm{Mg} / \mathrm{Ca}$ thermometry, which yielded a reconstruction of $\delta^{18} \mathrm{O}_{\mathrm{GOM}}$. They found that the early Holocene mean $\delta^{18} \mathrm{O}_{\mathrm{GOM}}$ was $0.9 \%$ (VSMOW) with centennial-scale oscillations of $0.5 \%$ above and below the mean (LoDico et al., 2006). $\delta^{18} \mathrm{O}_{\mathrm{GOM}}$ reached a minimum $(0.4 \%$ VSMOW, change $=-1 \%$ ) from 8.6 to $8.3 \mathrm{ka}$, interpreted as a low salinity event. However, due to age model uncertainty on the order of 100 years, LoDico et al. (2006) note that it is difficult to tell whether this is truly a response that preceded the $8.2 \mathrm{ka}$ event, or if the foraminifera were actually recording a synchronous response. It's possible that the source of the $-1 \%$ pulse was sourced from freshwater travelling from the Laurentide Ice Sheet (LoDico et al., 2006; Moore et al., 2000; Teller et al., 2002)

Regardless of the precise timing and source of the $\delta^{18} \mathrm{O}_{\mathrm{GOM}}$ minimum, it is significant for this work that the $\delta^{18} \mathrm{O}_{\mathrm{GOM}}$ decreased appreciably around $8.6 \mathrm{ka}$. The most commonly used speleothem geochemical proxy, $\delta^{18} \mathrm{O}_{\text {calcite, }}$, is generally interpreted as precipitation amount, based on previous work and ongoing local monitoring efforts (Frappier et al., 2014; Lachniet et al., 2013, 2017). However, $\delta^{18} \mathrm{O}_{\text {precip }}$ can also be influenced by changing moisture source or shifting $\delta^{18} \mathrm{O}$ of the source water, so it's important to verify $\delta^{18} \mathrm{O}$ results with other proxies. We showed in Chapter 3 that the majority of precipitation that reaches the NE Mexico region is sourced from the GOM and Atlantic (rather than the Pacific). Therefore, it is possible that decreasing $\delta^{18} \mathrm{O}_{\mathrm{GOM}}$ starting at $8.6 \mathrm{ka}$ could produce a similar decrease in $\delta^{18} \mathrm{O}_{\text {calcite }}$ in Rioverde. 
To get a better sense of how the $8.2 \mathrm{ka}$ event impacted precipitation NE Mexico without potential source effects on $\delta^{18} \mathrm{O}_{\text {calcite, }}$, we used a multiproxy approach, including $\delta^{13} \mathrm{C}$ and trace element to calcium ratios. The controls on $\delta^{13} \mathrm{C}$ are related to hydrology, but are not identical to those of $\delta^{18} \mathrm{O}$. Some of the most significant or relevant controls in the NE Mexican region include $\mathrm{CO}_{2}$ degassing, prior calcite precipitation (PCP), or changes in vegetation and soil conditions (Bajo et al., 2017; Borsato et al., 2016; Medina-Elizalde et al., 2016; Wong \& Breecker, 2015; Wright et al., in prep.). Under dry conditions, increased prior calcite precipitation, increased $\mathrm{CO}_{2}$ degassing, and decreased respiration can all increase the $\delta^{13} \mathrm{C}$ values observed in the speleothem. Furthermore, these same processes correspond to higher $\mathrm{Mg} / \mathrm{Ca}$ and $\mathrm{Sr} / \mathrm{Ca}$ values in the speleothem under dry environmental conditions (Fairchild et al., 2000, 2006; Tremaine \& Froelich, 2013).

\subsection{The Atlantic Meridional Overturning Circulation and Mexican Precipitation}

Wright et al. (in prep.) demonstrated that, on millennial timescales, orbital forcing is not a major driver of precipitation in the northeast Mexican region. Instead, weakened AMOC was a more important factor in reducing rainfall. The speleothem used in the Wright et al. (in prep.) paper demonstrated increased stable isotope ratios and $\mathrm{Mg} / \mathrm{Ca}$ during Heinrich Stadials due to AMOC weakening. The weakened northward heat transport to the North Atlantic yields a cooler Gulf of Mexico and Caribbean Sea, and intensifies the CLLJ. Freshwater hosing experiments demonstrated that stronger wind (the CLLJ) decreased precipitation by an estimated 1-2 mm per day and increased $\delta^{18} \mathrm{O}_{\text {precip }}$; along the same lines, strengthened AMOC conditions yielded increased precipitation and decreased $\delta^{18} \mathrm{O}_{\text {precip }}$ (Lohmann et al., 2016; Thiagarajan et al., 2014). Wind anomalies from a stronger CLLJ reduce moisture convergence over Mexico, while decreased SSTs decrease the moisture content of low-level air transported over the region (Wright et al., in prep.).

\subsection{Scientific questions}

In this work, we will attempt to answer several questions about past hydroclimate in NE Mexico, with our main focus on the 8.2 ka event. First, because we are missing high-resolution data from this region, we need to find out whether the $8.2 \mathrm{ka}$ event made conditions wetter, drier, or neither. Based on drier conditions recorded in the southwestern Mexican sediment core with pollen (Lozano-García et al., 2013), the drier Cueva del Diablo speleothem (Bernal et al., 2011), 
and drying after freshwater events (Wright et al., in prep.), we hypothesize that NE Mexico will be drier after the $8.2 \mathrm{ka}$, but the effect size is unknown.

If the $8.2 \mathrm{ka}$ event does appear in the NE Mexican precipitation record, we also need to investigate how long the shift(s) lasted. Response duration ranged from 150 to 400 years around the North Atlantic (Kobashi et al., 2007; Morrill, Legrande, et al., 2013). This will help put the $8.2 \mathrm{ka}$ event into context and illustrate how sensitive this region is to droughts (or other precipitation shifts). We will also investigate the North-South dipole discussed at length in Chapter 3. While the dipole has been confirmed during the Common Era and on millennial timescales, primarily controlled by SST, it has not been explored in-depth on decadal to centennial scales. We need more high-resolution data to understand how the dipole responds to AMOC weakening on short timescales.

Using the full suite of proxies, we will test whether the response to the $8.2 \mathrm{ka}$ was a true change in moisture amount, meaning that the proxies all record drying, or if it was a change in only one or two of the proxies. For example, Wright et al. (in prep.) showed that decreased soil moisture was the dominant response to freshwater input events on longer timescales.

Most importantly for modern residents of the San Luis Potosi region, we will explore this paleo record's implications about future climate change and water in this region, given (potential) ongoing weakening of AMOC.

\section{Methods}

\subsection{Cave and setting and stalagmite}

Grutas de la Catedral (GC) is the largest cave in a system or group of caves close to Rioverde, San Luis Potosi, Mexico, known as Grutas de la Catedral y del Angel (Cathedral and Angel Caves or Grottos). Rioverde is semi-arid, with cacti as the dominant vegetation, but it is not as dry as Cueva de la Puente (Chapter 3). From 2013 to 2017, GC received an average of $40 \%$ more wet season precipitation than did Cueva de la Puente (sum of MJJASO precipitation amount; we used an extended wet season to account for any potential seasonal differences). The majority of GC's precipitation falls during the boreal summer, with a notable mid-summer drought in July (Figure 1B). GC falls in between a region with recent droughts (negative PDSI) and another with recent wet periods (positive PDSI) (Figure 1A). 
PDSI
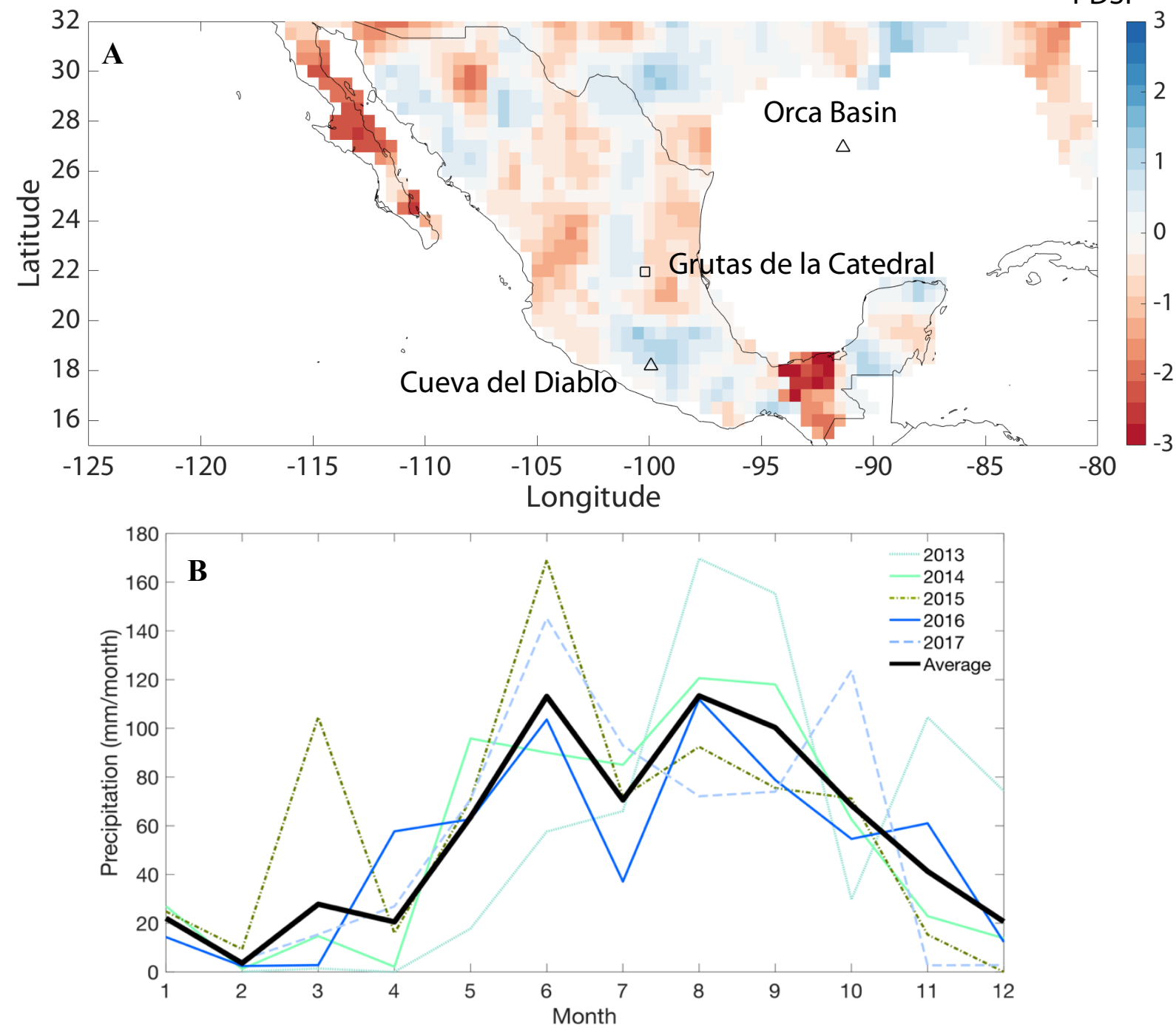

Figure 1. A. Location of Grutas de la Catedral (this study; black square), Cueva del Diablo (Bernal et al., 2011; black triangle), Orca Basin (LoDico et al., 2006; black triangle) over the median Palmer Drought Severity Index (PDSI) from 2000 to 2006 CE (Cook et al., 2004), which had high data coverage and no significant annual-scale events, such as the national drought in 2011. B. Climatology of monthly precipitation amount in Rioverde from 2013 to 2017, the most recent years with high data coverage. Based on daily data from CONAGUA station Nogal Oscuro $(22.03 \mathrm{~N}, 100.18 \mathrm{~W})$, averaged to monthly precipitation.

The entrance to GC $(21.94 \mathrm{~N}, 100.24 \mathrm{~W})$ is developed for tourism, but the majority of the system is inaccessible without vertical caving equipment. The chamber studied in this work is down a $20 \mathrm{~m}$ drop, a $\sim 1.5$ hour-long hike from the tourist area. Therefore, we are almost certain that the chamber is not influenced by tourist presence. 
GC1 is a $29 \mathrm{~cm}$ long, candlestick-shaped stalagmite that was sampled from GC. The texture is alternating translucent grey (dominant) and a white, more porous texture (less common). We have not yet completed XRD analysis to confirm that the sample is calcite, but trace element results show that the ratios are not changing based on visible texture. At present, we assume that this sample was precipitated under equilibrium conditions and that kinetic fractionation was not a significant control on stable isotope ratios. Once we are able to retrieve monitoring equipment and glass plates, we will be able to quantitatively demonstrate that this is the case.

\subsection{Monitoring and rainfall collection}

Samples of modern precipitation were collected by Juan Cancino in Rioverde over several months. We used evaporation-limiting precipitation collectors to collect the rain (Wright et al., in prep.), and stored samples in $1.5 \mathrm{ml}$ glass vials with conical inserts. Rain samples were analyzed for $\delta^{18} \mathrm{O}$ and $\delta \mathrm{D}$ at Chapman University. The $\delta^{18} \mathrm{O}$ of rainfall $\left(\delta^{18} \mathrm{O}_{\text {precip }}\right)$ was then averaged to monthly values and compared to CONAGUA-reported rainfall amount data to quantify the amount effect. Note that we are using the same amount effect data for this chapter and the previous chapter.

This is the first study of this cave, so we are working to establish basic information (i.e. temperature, relative humidity, $\mathrm{CO}_{2}$ ) about the modern environment. We left monitoring equipment in the cave for retrieval at a later date.

We determined the average monthly precipitation at GC using daily precipitation data from the nearest CONAGUA station, Nogal Oscuro (22.03N, 100.18W), from 2013 to 2017 (Figure 1).

\subsection{U-Series dating}

We dated 18 horizons along the growth axis of the stalagmite using $0.2 \mathrm{~g}$ of sample. Powders were dissolved, spiked, and processed following methods adapted from Edwards et al (1987). After removing $U$ and $T h$ from solution via iron coprecipitation, we separated $U$ and $T h$ in 0.5 $\mathrm{mL}$ bed volume columns with AG1-X8 resin (Lawrence Edwards et al., 1987). We analyzed both fractions with a Nu Plasma II multi-collector ICP-MS at MIT. Samples were bracketed with 2\% nitric acid blanks and CRM 112a standard with $13.5 \mathrm{ppb}{ }^{238} \mathrm{U}$. Total procedural blanks were 2.5 pg ${ }^{238} \mathrm{U}$ and $0.55 \mathrm{pg}{ }^{232} \mathrm{Th}$. We used an initial ${ }^{232} \mathrm{Th} /{ }^{230} \mathrm{Th}$ correction of $4.4 \pm 2.2 \mathrm{ppm}$, the 
standard correction in the MIT lab. We used the COPRA algorithm to run 2000 Monte Carlo simulations with PCHIP interpolation (Breitenbach et al., 2012). From these simulations, we extracted the median age-depth model and 95\% upper and lower confidence interval on the model.

\subsection{Stable isotopes and trace elements}

GC1 was continuously sampled by Gianna Lum at the UC Irvine Center for Isotope Tracers in Earth Sciences (CITIES) using a Sherline micromill at $0.5 \mathrm{~mm}$ resolution. Powders (n =46) were analyzed on a Kiel IV Carbonate Preparation Device coupled to a Thermo Scientific Delta V-IRMS following methods in McCabe-Glynn et al. (2013) to determine $\delta^{18} \mathrm{O}$ and $\delta^{13} \mathrm{C}$ (McCabe-Glynn et al., 2013). Samples of unknown composition were interspersed with standards, including NBS-18 and IAEA-CO-1. The analytical precision for $\delta^{18} \mathrm{O}$ and $\delta^{13} \mathrm{C}$ was $0.04 \%$ and $0.05 \%$, respectively.

All remaining powder was weighed out into samples of $\sim 1 \mathrm{mg}$, which were dissolved in 3\% nitric acid for trace element analysis at MIT. $\mathrm{Mg}, \mathrm{Ca}, \mathrm{Sr}$, and Th were measured with an Agilent 7900 in no-gas mode, then ratioed to metal/Ca. Day-to-day shifts in $\mathrm{Mg} / \mathrm{Ca}$ and $\mathrm{Sr} / \mathrm{Ca}$ measured in identical standard solutions ranged from $<1 \%$ to $5 \%$, so we focus our analysis on variability greater than $5 \%$. All data were corrected for instrumental drift using standards of known composition. 191 samples have been analyzed so far for trace element ratios, out of a total of more than 900 samples. Ca counts for all samples were tracked to ensure that there was enough powder to achieve $\mathrm{Mg}$ and $\mathrm{Sr}$ counts within the detection limits, and $\mathrm{Th} / \mathrm{Ca}$ was analyzed simultaneously to check for detritus. However, $\mathrm{Th} / \mathrm{Ca}$ in the $\mathrm{GC} 1$ sample was below $\mathrm{Th} / \mathrm{Ca}$ concentration in the rinse and blank solutions, so it was only detectable in some samples.

\subsection{Data analysis}

All data analysis was completed with MATLAB version 2018b and Python 3.7, used with Jupyter Lab. At this point, the trace element and stable isotope data are too sparse for wavelet analysis, but we will apply a wavelet toolbox for MATLAB (Grinsted et al., 2004) and the Climate Data Toolbox (Greene et al., 2019) once we have more high-resolution data.

In addition, it would be helpful for this work to include a freshwater hosing experiment that replicates the amount of fresh water thought to have been added to the Atlantic during the 
$8.2 \mathrm{ka}$ event, as in Wright et al. (in prep.). This has not yet been completed, but may be added to the analysis in the future.

\section{Results}

\subsection{U-Series dating}

8 samples in the top $150 \mathrm{~mm}$ of the stalagmite showed approximately continuous growth (no major hiatuses) from $8.90 \pm 0.06$ to $6.84 \pm 0.14 \mathrm{ka} \mathrm{BP}$ ( $\pm 2 \mathrm{SD}$ uncertainty). 6 of the 8 samples fell between 8.9 and $8.0 \mathrm{ka}$, with a mean uncertainty of 42 years; these precise dates allow for high confidence in analysis of the 8.2 ka event.

After $8.90 \pm 0.06 \mathrm{ka}$, there is a hiatus in growth, indicated by both U/Th dates and a thick band of detritus visible within the sample. The stalagmite sample extends another $\sim 150 \mathrm{~mm}$ (29 $\mathrm{cm}$ total length) after the hiatus, covering $11.56 \pm 0.14$ to $21.76 \pm 0.18 \mathrm{ka} \mathrm{BP}$ (Appendix), but there is currently very low proxy sample resolution, or no data, during these later time periods, so this work will focus on the top half. In total, we generated $18 \mathrm{U} / \mathrm{Th}$ dates with a median 2SD uncertainty of 70 years. Although we can make some preliminary conclusions because we have good age control on the lower half of the stalagmite (Appendix), additional proxy data will make the interpretations of the earlier sections much more rigorous.

Nonetheless, we note that the younger part of the second half of the stalagmite appears to have captured most of the Younger Dryas (12.84 to $11.65 \mathrm{ka}$, counting error $<44$ years, Rasmussen et al., 2006), the Bølling-Allerød (began at $14.69 \mathrm{ka}$, counting error $<186$ years), and the end of the glacial period (Appendix). We note rapid increase in $\mathrm{Mg} / \mathrm{Ca}$ and $\mathrm{Ba} / \mathrm{Ca}$ before the end of the Younger Dryas (Appendix). Once the additional proxy data points are complete, this work will compare this stalagmite's record of the $8.2 \mathrm{ka}$ event to that of the Younger Dryas, as well as comparing this sampling site to a site further to the east (Wright et al., in prep.) and southwestern Mexico, at Juxtlahuaca Cave (Lachniet et al., 2013). 

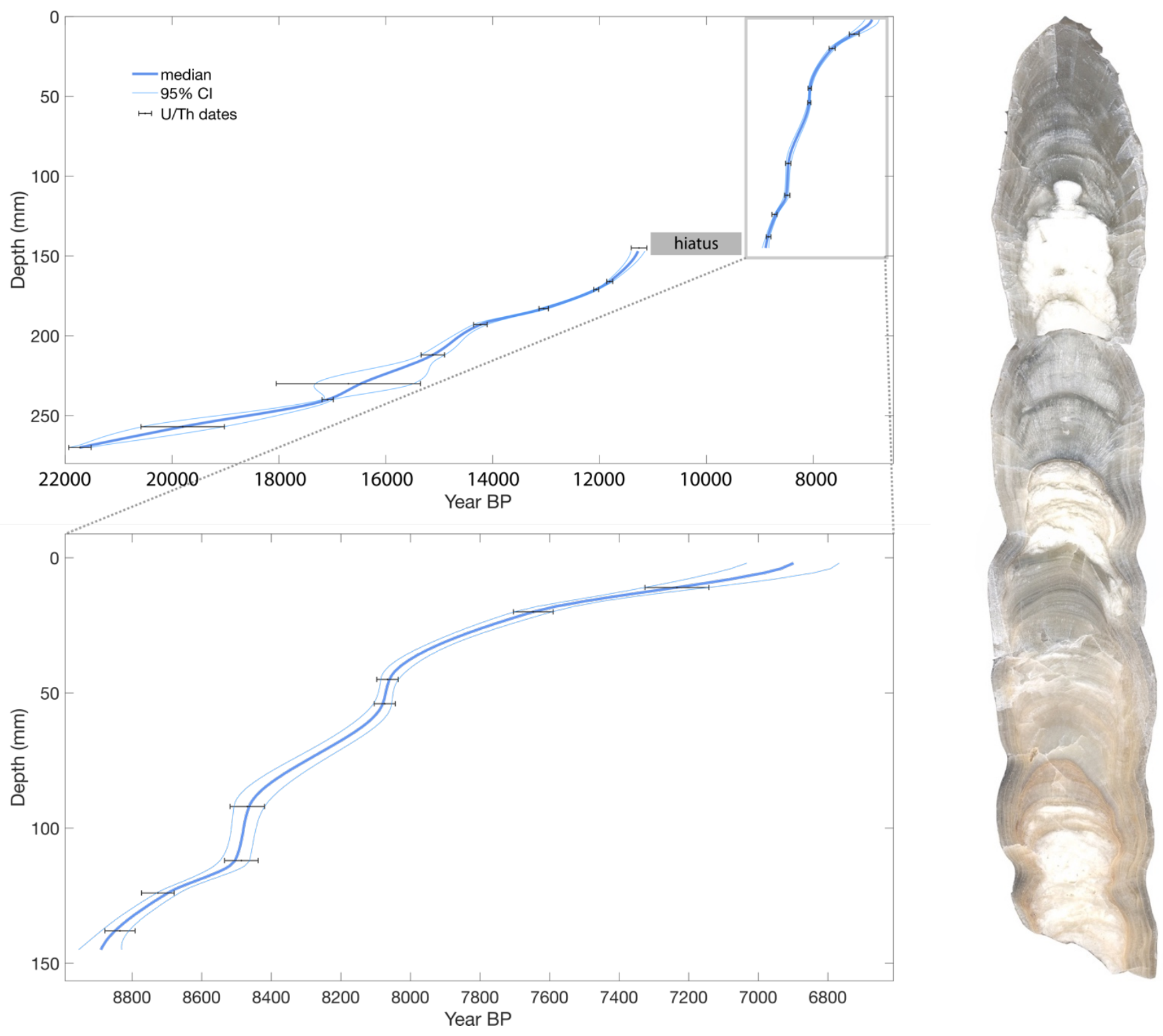

Figure 2. Age-depth model for $\mathrm{GC} 1$ based on $18 \mathrm{U} /$ Th dates and 2000 Monte Carlo simulations in COPRA (Breitenbach et al., 2012). Inset shows the top $150 \mathrm{~mm}$ of the stalagmite, which covers the 8.2 ka event (full time span of the top $150 \mathrm{~mm}$ is $8.90 \pm 0.06$ to $6.84 \pm 0.14 \mathrm{ka} \mathrm{BP}$ ). There is a hiatus around $150 \mathrm{~mm}$ from the top, which lasted for approximately $2 \mathrm{ka}$. Scanned cross-section of the stalagmite is shown on the right.

\subsection{Stable isotopes and trace element ratios}

We report data from the older portion of the stalagmite in the Appendix, but for the sake of clarity and specificity, references to statistics and values in this results section will focus exclusively on the portion younger than $8.9 \mathrm{ka}$, unless otherwise specified. Proxy data from 7.4 to $6.8 \mathrm{ka}$ are not plotted due to low resolution or large gaps between samples. 
The top $150 \mathrm{~mm}$ of the stalagmite was sampled at $0.5 \mathrm{~mm}$, but only some of that data has been analyzed, so the effective resolution averages $1 \mathrm{~mm}$. Existing data have a median temporal resolution of 6 years per sample, or sub-decadal resolution. This is much higher resolution than most other samples from this time period, due to rapid growth in GC1. For comparison, proxy data needed to have $<15$ years per sample to be considered in an 8.2 ka proxy assimilation (Morrill, Anderson, et al., 2013); GC1 fits these criteria. This high-resolution data is even more informative because it is paired with low dating uncertainty ( $<50$ years at $8.2 \mathrm{ka}$ ). Although we have not yet achieved sub-decadal resolution with all proxy measurements, the lower resolution data will complement the high-resolution trace element data.
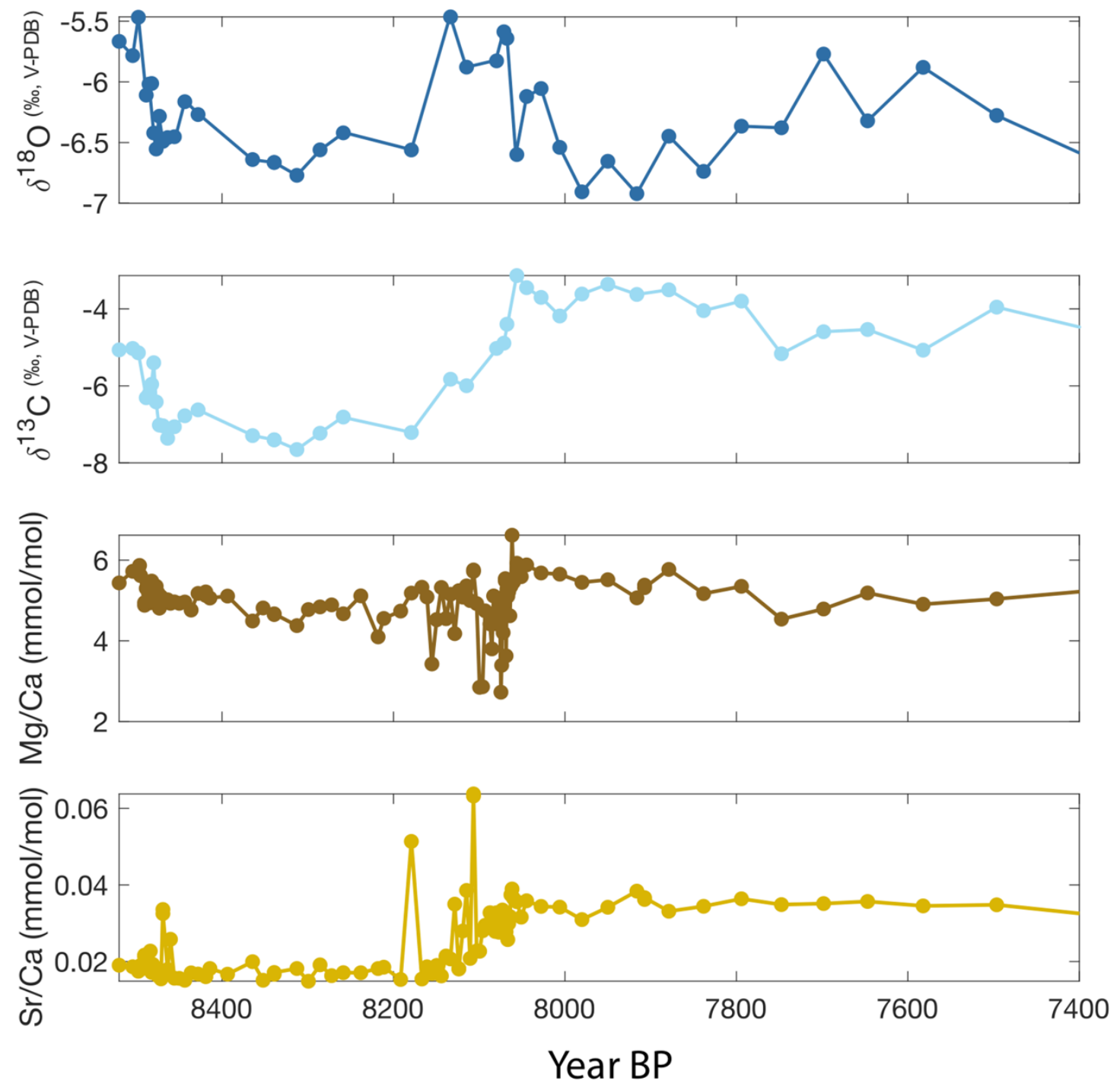

Figure 3. Stable isotope and trace metal to calcium ratios for the younger portion of GC1, a stalagmite from northeastern Mexico. All four proxy records show some response to the 8.2 
ka event. Proxy data from 7.5 to 6.8 ka have been sampled, but are not plotted due to low resolution/large gaps between samples.

Mean $\delta^{18} \mathrm{O}_{\text {calcite }}$ was $-6.2 \pm 0.86 \%$ ( $\pm 2 \mathrm{SD}$ ), ranging from -6.9 to $-5.2 \%$. During the $8.2 \mathrm{ka}$ event ( 8.179 to $8.056 \mathrm{ka}$ ), maximum $\delta^{18} \mathrm{O}$ was $-5.5 \%$, a $0.73 \%$ increase above mean values (Figure 3). $\delta^{13} \mathrm{C}$ showed larger amplitude variability than $\delta^{18} \mathrm{O}$, with a mean of $-5.2 \pm 3.1 \%$ o $( \pm$ $2 \mathrm{SD})$. There was a $4.1 \%$ increase from $8.18 \mathrm{ka}$ to the local maximum values at $8.056 \mathrm{ka}$. Unlike $\delta^{18} \mathrm{O}, \delta^{13} \mathrm{C}$ values did not return to the previous baseline after the $8.2 \mathrm{ka}$ event, at least until the speleothem stopped growing around $6.9 \mathrm{ka}$.

Mean $\mathrm{Mg} / \mathrm{Ca}$ was $5.039 \pm 1.44 \mathrm{mmol} / \mathrm{mol}( \pm 2 \mathrm{SD})$ and mean $\mathrm{Sr} / \mathrm{Ca}$ was $0.0285 \pm 0.019$ $\mathrm{mmol} / \mathrm{mol}( \pm 2 \mathrm{SD})$. It is possible that the $2 \mathrm{SD}$ of $\mathrm{Sr} / \mathrm{Ca}$ is artificially high because of the two single-point peaks (Figure 3); however, there were no signs of instrumental error for those data points. Specifically, $\mathrm{Mg} / \mathrm{Ca}$ is not abnormally high, nor was $\mathrm{Th} / \mathrm{Ca}$, which could indicate a layer of clay or other contaminants. Nonetheless, samples from around those points will be (re)analyzed to ensure that these are real increases in $\mathrm{Sr} / \mathrm{Ca}$.

After the hiatus that marks the start of the section of the speleothem we focus on here, both stable isotopes decreased from 8.6 to $8.5 \mathrm{ka}$, which we interpret as a change toward wetter conditions. Though we are aware that hiatuses do not always mark a dry period, the decrease toward wetter conditions at the very start of the younger growth period is consistent with the hiatus marking dry conditions, followed by growth starting, and conditions continuing toward wetter hydroclimate. Then, there is little variability in stable isotopes until the $8.2 \mathrm{ka}$ event. The trend from 8.6 to $8.5 \mathrm{ka}$ is not replicated in the trace element ratios, suggesting that primary calcite precipitation was not occurring.

$\delta^{13} \mathrm{C}, \mathrm{Mg} / \mathrm{Ca}$, and $\mathrm{Sr} / \mathrm{Ca}$ show a shifted (increased) baseline after $8.2 \mathrm{ka}$ event. Both $\delta^{13} \mathrm{C}$ and $\mathrm{Sr} / \mathrm{Ca}$ were significantly higher after $8.2 \mathrm{ka}$ (unpaired t-test, $\delta^{13} \mathrm{C} \mathrm{p}$-value $<<0.001, \mathrm{Sr} / \mathrm{Ca} \mathrm{p}$ value $=0.23) . \mathrm{Mg} / \mathrm{Ca}$ became more variable and showed an overall trend of increased values from 8.2 to $8.0 \mathrm{ka}$, but the mean was not significantly different (unpaired t-test, $\mathrm{p}$-value $=0.59$ ). In contrast, $\delta^{18} \mathrm{O}$ had a $\sim 1 \%$ increase from 8.2 to $8.1 \mathrm{ka} \mathrm{BP}$, but decreased back to baseline (or lower than baseline) pre-event values after $8 \mathrm{ka}$; there was no statistically significant difference in the median or mean (Wilcoxon test and unpaired t-test, both p-values $>0.3$ ). 

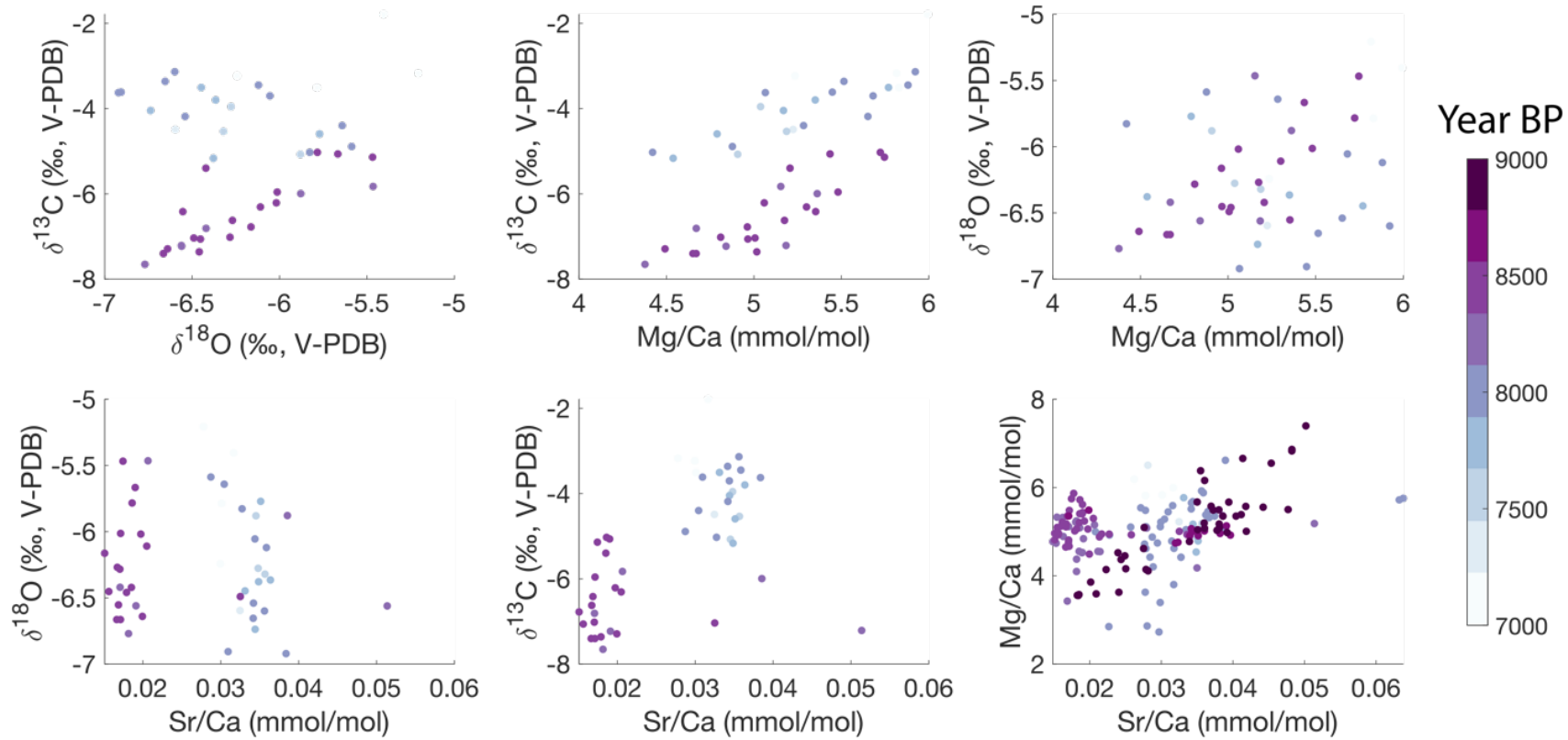

Figure 4. Cross plots of geochemical proxies $\left(\delta^{18} \mathrm{O}, \delta^{13} \mathrm{C}, \mathrm{Mg} / \mathrm{Ca}\right.$, and $\left.\mathrm{Sr} / \mathrm{Ca}\right)$ from $\mathrm{GC}$. We note the presence of two distinct populations in most proxies, split around the 8ka BP mark.

When comparing proxy relationships from before and after the $8.2 \mathrm{ka}$ event, we also found differences in correlation (slope) between the proxies, especially $\delta^{13} \mathrm{C}$ (Figure 4). Before $8.2 \mathrm{ka}, \delta^{18} \mathrm{O}$ and $\delta^{13} \mathrm{C}$ are significantly correlated (Spearman's $\rho=0.89$, p-value $<<0.001$ ), but after $\sim 8.0 \mathrm{ka}$, they are not significantly correlated (Spearman's $\rho=-0.11$, p-value $=0.57$ ). The change in correlation is indicative that $\delta^{13} \mathrm{C}$ is less sensitive to changes in hydrology that affect $\delta^{18} \mathrm{O}$ after $8.2 \mathrm{ka}$.

There is no similar pattern in trace element to calcium ratios. Both before and after 8.2 $\mathrm{ka}$, the rank correlation between $\mathrm{Mg} / \mathrm{Ca}$ and $\mathrm{Sr} / \mathrm{Ca}$ is positive $(\rho=0.33)$; the statistical significance decreases slightly after $8.2 \mathrm{ka}$, but remains significant (before $8.2 \mathrm{ka}$, p-value $=$ 0.0011 ; after $8.2 \mathrm{ka}$, $\mathrm{p}$-value $=0.0049$ ). We also tested the correlation between the natural log of $\mathrm{Mg} / \mathrm{Ca}$ and $\mathrm{Sr} / \mathrm{Ca}$ (Figure 5), which some studies have used as an indicator of prior calcite precipitation (Sinclair et al., 2012). The scatter plot yielded a slope of 0.68 , which is close to the slopes of 0.7-1 suggested to relate to PCP (Sinclair et al., 2012). However, due to the low correlation coefficient $\left(r^{2}=0.1\right)$, we will not analyze this relationship in depth.

The number of samples is much higher for trace elements $(n=170)$ than stable isotopes ( $n=46$ ), so we did not calculate the correlation between the two types of proxies. Qualitatively, there appears to be little relationship between $\mathrm{Sr} / \mathrm{Ca}$ and $\delta^{18} \mathrm{O}$ (Figure 4), as $\mathrm{Sr} / \mathrm{Ca}$ shows two 
distinct populations, low before the $8.2 \mathrm{ka}$ and higher after, that span a full range of $\delta^{18} \mathrm{O}$ values. $\delta^{13} \mathrm{C}$ and $\mathrm{Sr} / \mathrm{Ca}$ are more correlated in that the $\delta^{13} \mathrm{C}$ values are also higher for the younger, higher population of $\mathrm{Sr} / \mathrm{Ca}$ data.

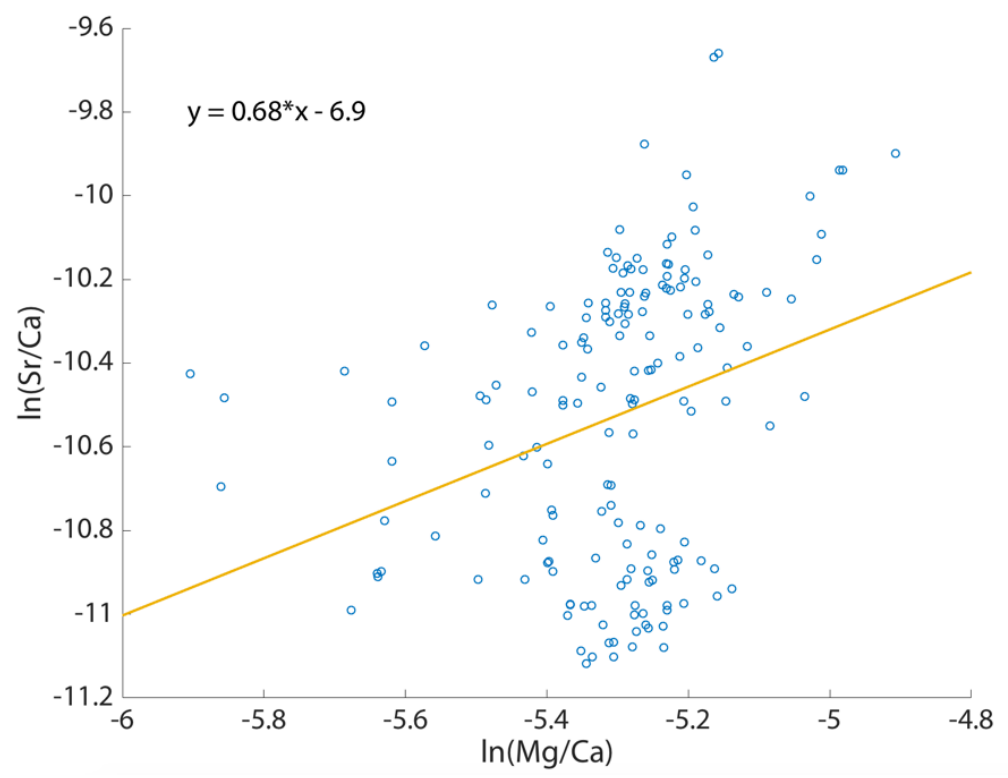

Figure 5. Cross plot of $\ln (\mathrm{Mg} / \mathrm{Ca})$ and $\ln (\mathrm{Sr} / \mathrm{Ca})$. The slope is 0.68 , which approaches the estimated slope related to prior calcite precipitation $(m=0.7-1)$ (Sinclair et al., 2012). However, the low correlation coefficient $\left(r^{2}=0.1\right)$ suggests that this is not a robust analysis.

\subsection{Comparison to other records}

We used the Greenland Ice Sheet Project 2 (GISP2) record of methane and nitrogen stable isotopes to represent the canonical $8.2 \mathrm{ka}$ event (Figure 5). The GISP2 record captured a sharp cooling event starting at $8.175 \mathrm{ka} \pm 30$ years which continued for 150 to 160 years (Figure 5, dashed grey lines) (Kobashi et al., 2007; Thomas et al., 2007). At the same time, reconstructed Gulf of Mexico SST showed two cycles of $\sim 1^{\circ} \mathrm{C}$ temperature change between 8.2 and 8.0 (Figure 5) (LoDico et al., 2006). As detailed in the introduction section, $\delta^{18} \mathrm{O}_{\mathrm{GOM}}$ may have decreased by 1\%o earlier than the $8.2 \mathrm{ka}$ event (from 8.6 to $8.4 \mathrm{ka}$ ), but age model uncertainty and coarse sampling resolution made it difficult to diagnose the exact timing (LoDico et al., 2006). GC1 $\delta^{18} \mathrm{O}_{\text {calcite }}$ also decreases from 8.5 to $8.4 \mathrm{ka}$, which could suggest that changing $\delta^{18} \mathrm{O}_{\mathrm{GOM}}$ is a major driver of $\mathrm{GC} 1 \delta^{18} \mathrm{O}_{\text {calcite, }}$ but we note that $\mathrm{GC} 1 \delta^{13} \mathrm{C}$ also decreases at the same time (Figures 5 and 7). Because $\delta^{18} \mathrm{O}$ and $\delta^{13} \mathrm{C}$ both decreased from 8.5 to $8.4 \mathrm{ka}$, we know that they are both being controlled by moisture amount, not $\delta^{18} \mathrm{O}$ of source water. Furthermore, $\delta^{18} \mathrm{O}_{\mathrm{GOM}}$ increased rapidly from 8.4 to $8.3 \mathrm{ka}$, which is not reflected in the $\mathrm{GC} 1$ record. Therefore, the 
synchronous increase in $\mathrm{GC} 1 \delta^{18} \mathrm{O}_{\text {calcite }}$ and the three other proxies at $8.2 \mathrm{ka}$ is indicative of drier conditions. This question highlights the importance of multiproxy sampling in speleothems.

In an ideal case, we would prefer to compare the GC1 data to other high-resolution records from the same region to better understand the different responses recorded in $\delta^{18} \mathrm{O}_{\text {calcite }}$ versus the other proxies. However, there appear to be very few local records. The closest speleothem sample is from Cueva del Diablo (Bernal et al., 2011), which had a growth hiatus during the $8.2 \mathrm{ka}$ event (Figure 6); the data that do exist from before and after the $8.2 \mathrm{ka}$ event are coarse, with resolution of $\sim 50$ years per sample. Nonetheless, the pause in growth at this specific period does support lower precipitation in Mexico during the $8.2 \mathrm{ka}$ event.

In comparing the $\delta^{13} \mathrm{C}$ record from GC1 to the GISP2 data (Kobashi et al., 2007), we note that the GC1 increase is synchronous with the beginning of the $8.2 \mathrm{ka}$ event (Figure 6). Age model uncertainty (or timing uncertainty for the $8.2 \mathrm{ka}$ event) is similar in both GC1 and GISP2, approximately 50 years. 


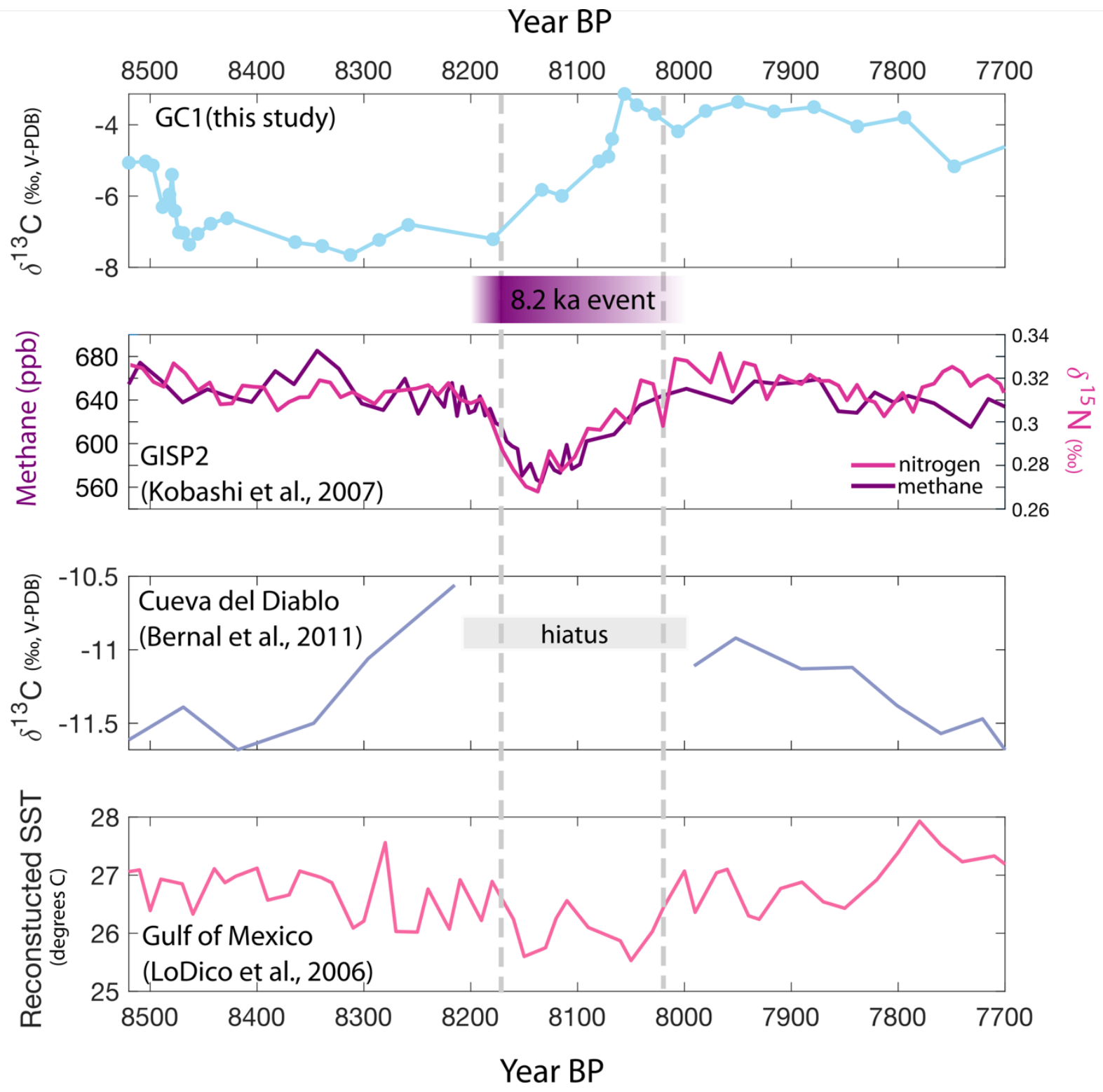

Figure 6. Increasing $\delta^{13} \mathrm{C}$ in GC1 observed at 8.2 ka was synchronous with changes recorded in the Greenland Ice Sheet (Kobashi et al., 2007), a hiatus in a stalagmite from central Mexico, interpreted as extremely dry climate (Bernal et al., 2011), and a $1^{\circ} \mathrm{C}$ decrease in GoM SST (LoDico et al., 2006). Grey lines are the beginning and end based on GISP2. Color gradient for 8.2 ka represents uncertainty in age model at the start and end, 150 years later. 

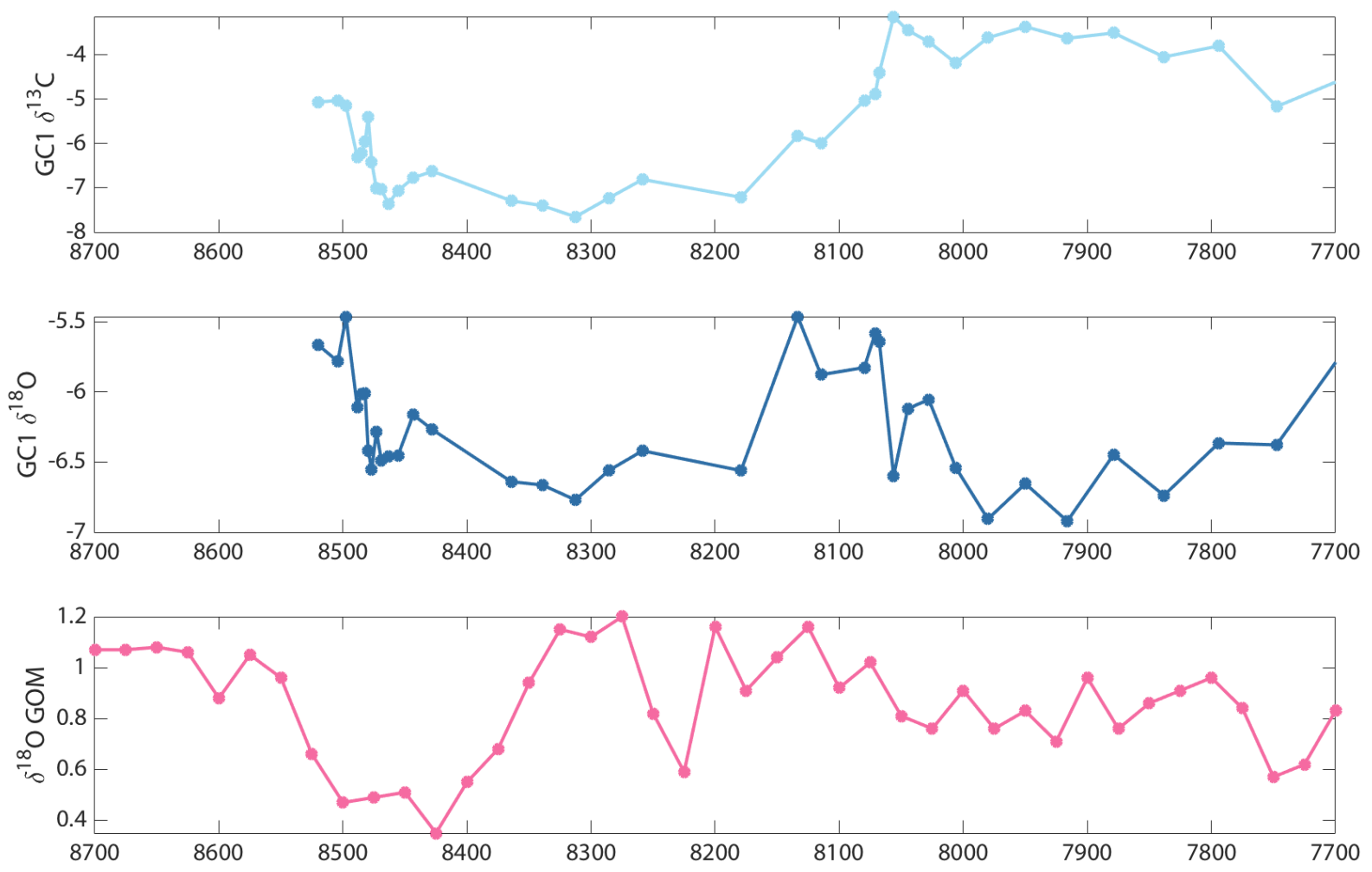

Figure 7. Comparison of GC1 stable isotope data with reconstructed $\delta^{18} \mathrm{O}_{\mathrm{GOM}}$ (LoDico et al., 2006) across the 8.2 ka event. Reconstructed $\delta^{18} \mathrm{O}_{\mathrm{GOM}}, \mathrm{GC} 1 \delta^{18} \mathrm{O}_{\text {calcite }}$, and $\mathrm{GC} 1 \delta^{13} \mathrm{C}_{\text {calcite }}$ all decrease from 8.5 to $8.4 \mathrm{ka}$, but $\delta^{18} \mathrm{O}_{\text {Gom }}$ shows an opposite pattern from 8.4 to $8.2 \mathrm{ka}$.

\section{Discussion}

\subsection{Interpretation of the $8.2 \mathrm{ka}$ response}

The primary goal of this research was to find out how the arid part of Mexico responded to the $8.2 \mathrm{ka}$ event, and to detect how long its effects lasted. We interpret the increase in $\delta^{18} \mathrm{O}$ from 8.2 to $8.0 \mathrm{ka}$ as a short term, direct impact of the $8.2 \mathrm{ka}$ event. Furthermore, we demonstrated that $\delta^{18} \mathrm{O}$ is most likely controlled by precipitation amount, rather than change in source water $\delta^{18} \mathrm{O}$ or a moisture source change. Therefore, increased $\delta^{18} \mathrm{O}$ is indicative of drying in northern Mexico. It is highly likely that this drying occurred because of the $8.2 \mathrm{ka}$ freshwater outflow into the Atlantic, and not simply by chance, because of the synchronicity with the GISP2 ice core records, which showed decreased methane and $\delta^{15} \mathrm{~N}$ from 8.2 to $8.0 \mathrm{ka}$. As detailed in Wright et al. (in prep.), a possible mechanism for decreased precipitation in response to weakened AMOC is the combination of a strengthened CLLJ and a reduction in Caribbean SSTs, 
which would increase moisture export from NE Mexico and decrease moisture import from the Caribbean, respectively.

Based on the significantly increased mean values observed in $\delta^{13} \mathrm{C}$ and $\mathrm{Sr} / \mathrm{Ca}$ (and, to a lesser extent, the slight increase in $\mathrm{Mg} / \mathrm{Ca}$ ), which increased at the same time as $\delta^{18} \mathrm{O}$, we show that moisture amount was not the only major change in northern Mexico. In $\mathrm{GC} 1, \delta^{18} \mathrm{O}$ reached a local maximum almost 100 years earlier than the other proxies (local maximum $\delta^{18} \mathrm{O}$ at $8.13 \mathrm{ka}$, local maximum $\delta^{13} \mathrm{C}$ at $8.05 \mathrm{ka}$ ). We suggest that the trace elements and $\delta^{13} \mathrm{C}$ were slower to respond because they reflect a longer-term shift in the environment in NE Mexico, similar to what Steponaitis et al. (2015) noted in Nevada. We interpret the increases in other proxies as decreasing soil moisture, changing vegetation, and increased PCP in the karst. In northern Mexico, the $8.2 \mathrm{ka}$ event was just the beginning of a larger change.

In addition, we note that the $8.2 \mathrm{ka}$ event was strong enough to disrupt the dipole pattern of precipitation, as far as we can tell from the southern Mexico Cueva del Diablo hiatus (Bernal et al., 2011), forest change in the southwest (Lozano-García et al., 2013) and proxy assimilation (Morrill, Anderson, et al., 2013), in combination with the northeast Mexican record in GC1. Costa Rica and the Cariaco Basin also showed summer drying, which supports both the disrupted dipole and a southward-shifted ITCZ (Haug et al., 2001; Lachniet et al., 2004).

Decadal-scale resolution and low age uncertainty means this record should be incorporated as a benchmark for future $8.2 \mathrm{ka}$ event modeling, especially because it is the only record between New Mexico and southern Mexico to record the $8.2 \mathrm{ka}$ event at that level of resolution.

\subsection{Implications for future climate change}

If we assume that estimated AMOC reduction of 10-25\% during the $8.2 \mathrm{ka}$, and future projections of AMOC weakening, are both correct, the $8.2 \mathrm{ka}$ event can be considered an imperfect analog for future climate change. Therefore, the results of this study have serious implications for Rioverde and northern Mexico more broadly, because weakened AMOC could lead to significant drying. Given that the deep aquifer is already being depleted rapidly, a longterm drought that further limits aquifer recharge could cause worsened water scarcity and poor water quality. The long-term impacts on vegetation/degassing are particularly concerning, because a 10-25\% decrease in AMOC strength appears to have generated extensive, long-term 
change in the soil and ecosystem above the cave. Further work is needed to determine whether there was a longer, slower background climate shift starting at $8.2 \mathrm{ka}$ in addition to the abrupt change; that clarification has important implications for modeling future precipitation changes.

\section{Conclusions}

\subsection{Conclusions}

This work presents the first high resolution, precisely dated record of the $8.2 \mathrm{ka}$ event in northern (arid) Mexico. We found that the $8.2 \mathrm{ka}$ event yielded decreased precipitation amount for $\sim 200$ years in NE Mexico (increased $\delta^{18} \mathrm{O}$ ), but increased $\delta^{13} \mathrm{C}, \mathrm{Mg} / \mathrm{Ca}$, and $\mathrm{Sr} / \mathrm{Ca}$ ratios suggest that the $8.2 \mathrm{ka}$ event was just the beginning of a longer-term change in climate, as the increased mean (drier conditions) remained for more than 1,000 years. This region is sensitive to drought, especially as AMOC weakens. These results suggest that the San Luis Potosi region needs more drought preparedness and hydrological engineering to improve water scarcity as soon as possible. Future work will also present data from the Younger Dryas and the BøllingAllerød, other significant climate events that will further elucidate how northern Mexico responds to a changing Atlantic Ocean.

\subsection{Future Work}

Though we have not examined the existing, low resolution data in detail, it is exciting that the YD and Bølling-Allerød were captured in GC1. We plan to run stable isotope ratio analysis on the $0.5 \mathrm{~mm}$ sampled powders around the YD to get the full potential resolution on the multiproxy dataset. There are also 500 powders still to be analyzed for higher resolution trace metal data, both in the top part of the stalagmite that we have studied in-depth and the bottom, older part. Our interpretations would also benefit from a few more U-series dates around the 8.2 ka and YD to make sure we have the smallest possible uncertainty, especially because this speleothem dataset could be one of the best-constrained records of the $8.2 \mathrm{ka}$ event in Mexico.

When travel restrictions are lifted after COVID-19, it would be helpful to perform at least

one field trip to the cave to retrieve monitoring devices, measure the modern cave environment, and place or retrieve glass plates to farm calcite. 


\section{Acknowledgements}

We acknowledge support from NSF grants AGS-1804512 and AGS-1806090. We also appreciate funding from the MIT EAPS Student Research Fund, the MIT MISTI Mexico program, and an NSF GRFP award (GSM). Initial work for this project was also supported by UC MEXUS-CONACYT Collaborative Grant from the University of California Institute for Mexico and the United States (UC MEXUS CN-16-120). We appreciate drilling work by Gianna Lum, rainfall sampling by Cheva Berrones-Benitez and Juan Cancino, and field assistance from Jim Kennedy, Esteban Berrones, Corinne Wong, and Chris Wood. Collaborators include Kevin Wright, Tripti Bhattacharya, Kathleen Johnson, Laura Beramendi-Orosco, Juan Cancino, and Sergio Sanchez-Armass.

\section{References}

Aguilar-Ortega, F., Charcas-Salazar, H., Aguirre-Rivera, J. R., Castro-Larragoitia, J., \& FloresFlores, J. L. (2010). Estado actual del aprovechamiento del agua subterránea del valle de Rioverde, San Luis Potosí, México. Tecnologia y Ciencias Del Agua.

Alley, R. B., Mayewski, P. A., Sowers, T., Stuiver, M., Taylor, K. C., \& Clark, P. U. (1997). Holocene climatic instability: A prominent, widespread event 8200 yr ago. Geology, 25(6), 483-486. https://doi.org/10.1130/0091-7613(1997)025<0483:HCIAPW>2.3.CO;2

Asmerom, Y., Polyak, V., Burns, S., \& Rassmssen, J. (2007). Solar forcing of Holocene climate: New insights from a speleothem record, southwestern United States. Geology. https://doi.org/10.1130/G22865A.1

Bajo, P., Borsato, A., Drysdale, R., Hua, Q., Frisia, S., Zanchetta, G., Hellstrom, J., \& Woodhead, J. (2017). Stalagmite carbon isotopes and dead carbon proportion (DCP) in a near-closed-system situation: An interplay between sulphuric and carbonic acid dissolution. Geochimica et Cosmochimica Acta. https://doi.org/10.1016/j.gca.2017.04.038

Bernal, J. P., Lachniet, M. S., McCulloch, M., Mortimer, G., Morales, P., \& Cienfuegos, E. (2011). A speleothem record of Holocene climate variability from southwestern Mexico. Quaternary Research, 75(1), 104-113. https://doi.org/10.1016/j.yqres.2010.09.002

Borsato, A., Johnston, V. E., Frisia, S., Miorandi, R., \& Corradini, F. (2016). Temperature and altitudinal influence on karst dripwater chemistry: Implications for regional-scale palaeoclimate reconstructions from speleothems. Geochimica et Cosmochimica Acta. https://doi.org/10.1016/j.gca.2015.11.043

Breitenbach, S. F. M., Rehfeld, K., Goswami, B., Baldini, J. U. L., Ridley, H. E., Kennett, D. J., Prufer, K. M., Aquino, V. V., Asmerom, Y., Polyak, V. J., Cheng, H., Kurths, J., \& Marwan, N. (2012). Constructing proxy records from age models (COPRA). Climate of the Past, 8(5), 1765-1779. https://doi.org/10.5194/cp-8-1765-2012

Cook, E. R., Woodhouse, C. A., Eakin, C. M., Meko, D. H., \& Stahle, D. W. (2004). Long-term aridity changes in the western United States. Science, 306(5698), 1015-1018. https://doi.org/10.1126/science.1102586

Cronin, T. M., Vogt, P. R., Willard, D. A., Thunell, R., Halka, J., Berke, M., \& Pohlman, J. (2007). Rapid sea level rise and ice sheet response to 8,200-year climate event. Geophysical Research Letters, 34(20). https://doi.org/10.1029/2007GL031318

Ebbesen, H., \& Hald, M. (2004). Unstable Younger Dryas climate in the northeast North Atlantic. Geology, 32(8), 673-676. https://doi.org/10.1130/G20653.1

Fairchild, I. J., Borsato, A., Tooth, A. F., Frisia, S., Hawkesworth, C. J., Huang, Y., McDermott, 
F., \& Spiro, B. (2000). Controls on trace element ( $\mathrm{Sr}-\mathrm{Mg})$ compositions of carbonate cave waters: implications for speleothem climatic records. Chem Geol, 166(3-4), 255-269. https://doi.org/10.1016/s0009-2541(99)00216-8

Fairchild, I. J., Smith, C. L., Baker, A., Fuller, L., Spötl, C., Mattey, D., \& McDermott, F. (2006). Modification and preservation of environmental signals in speleothems. EarthScience Reviews. https://doi.org/10.1016/j.earscirev.2005.08.003

Frappier, A. B., Pyburn, J., Pinkey-Drobnis, A. D., Wang, X., Corbett, D. R., \& Dahlin, B. H. (2014). Two millennia of tropical cyclone-induced mud layers in a northern Yucatán stalagmite: Multiple overlapping climatic hazards during the Maya Terminal Classic "megadroughts." Geophysical Research Letters, 41(14), 5148-5157. https://doi.org/10.1002/2014GL059882

Greene, C. A., Thirumalai, K., Kearney, K. A., Delgado, J. M., Schwanghart, W., Wolfenbarger, N. S., Thyng, K. M., Gwyther, D. E., Gardner, A. S., \& Blankenship, D. D. (2019). The Climate Data Toolbox for MATLAB. Geochemistry, Geophysics, Geosystems, 20(7), 3774 3781. https://doi.org/10.1029/2019GC008392

Grinsted, A., Moore, J. C., \& Jevrejeva, S. (2004). Application of the cross wavelet transform and wavelet coherence to geophysical time series. Nonlinear Processes in Geophysics. https://doi.org/10.5194/npg-11-561-2004

Haug, G. H., Hughen, K. A., Sigman, D. M., \& Peterson, L. C. (2001). Southward migration of the intertropical convergence zone through the Holocene. Science.

Kendall, R. A., Mitrovica, J. X., Milne, G. A., Törnqvist, T. E., \& Li, Y. (2008). The sea-level fingerprint of the 8.2 ka climate event. Geology. https://doi.org/10.1130/G24550A.1

Kobashi, T., Severinghaus, J. P., Brook, E. J., Barnola, J. M., \& Grachev, A. M. (2007). Precise timing and characterization of abrupt climate change 8200 years ago from air trapped in polar ice. Quaternary Science Reviews. https://doi.org/10.1016/j.quascirev.2007.01.009

Lachniet, M. S., Asmerom, Y., Bernal, J. P., Polyak, V. J., \& Vazquez-Selem, L. (2013). Orbital pacing and ocean circulation-induced collapses of the Mesoamerican monsoon over the past 22,000 y. Proceedings of the National Academy of Sciences, 110(23), 9255-9260. https://doi.org/10.1073/pnas.1222804110

Lachniet, M. S., Asmerom, Y., Polyak, V., \& Bernal, J. P. (2017). Two millennia of Mesoamerican monsoon variability driven by Pacific and Atlantic synergistic forcing. Quaternary Science Reviews, 155, 100-113. https://doi.org/10.1016/j.quascirev.2016.11.012

Lachniet, M. S., Asmerom, Y., Polyak, V., \& Denniston, R. (2020). Great Basin Paleoclimate and Aridity Linked to Arctic Warming and Tropical Pacific Sea Surface Temperatures. Paleoceanography and Paleoclimatology. https://doi.org/10.1029/2019PA003785

Lachniet, M. S., Burns, S. J., Piperno, D. R., Asmerom, Y., Polyak, V. J., Moy, C. M., \& Christenson, K. (2004). A 1500-year El Niño/Southern Oscillation and rainfall history for the Isthmus of Panama from speleothem calcite. Journal of Geophysical Research D: Atmospheres, 109(20). https://doi.org/10.1029/2004JD004694

Lawrence Edwards, R., Chen, J. H., \& Wasserburg, G. J. (1987). 238U234U230Th232Th systematics and the precise measurement of time over the past 500,000 years. Earth and Planetary Science Letters, 81(2-3), 175-192. https://doi.org/10.1016/0012-821X(87)901543

LoDico, J. M., Flower, B. P., \& Quinn, T. M. (2006). Subcentennial-scale climatic and hydrologic variability in the Gulf of Mexico during the early Holocene. Paleoceanography. 
https://doi.org/10.1029/2005PA001243

Lohmann, G., Zhang, X., \& Knorr, G. (2016). Abrupt climate change experiments: The role of freshwater, ice sheets and deglacial warming for the Atlantic Meridional Overturning Circulation. Polarforschung, 85(2), 161-170. https://doi.org/10.2312/polfor.2016.013

Lozano-García, S., Torres-Rodríguez, E., Ortega, B., Vázquez, G., \& Caballero, M. (2013). Ecosystem responses to climate and disturbances in western central Mexico during the late Pleistocene and Holocene. Palaeogeography, Palaeoclimatology, Palaeoecology, 370, 184 195. https://doi.org/10.1016/j.palaeo.2012.12.006

Martinez, S., Escolero, O., \& Kralisch, S. (2010). Water management in San Luis Potosí Metropolitan Area, Mexico. International Journal of Water Resources Development. https://doi.org/10.1080/07900627.2010.489292

Matero, I. S. O., Gregoire, L. J., Ivanovic, R. F., Tindall, J. C., \& Haywood, A. M. (2017). The 8.2 ka cooling event caused by Laurentide ice saddle collapse. Earth and Planetary Science Letters. https://doi.org/10.1016/j.epsl.2017.06.011

McCabe-Glynn, S., Johnson, K. R., Strong, C., Berkelhammer, M., Sinha, A., Cheng, H., \& Edwards, R. L. (2013). Variable North Pacific influence on drought in southwestern North America since AD 854. Nature Geoscience, 6(8), 617-621. https://doi.org/10.1038/ngeo1862

McGee, D., Donohoe, A., Marshall, J., \& Ferreira, D. (2014). Changes in ITCZ location and cross-equatorial heat transport at the Last Glacial Maximum, Heinrich Stadial 1, and the mid-Holocene. Earth and Planetary Science Letters, 390, 69-79. https://doi.org/10.1016/j.epsl.2013.12.043

Medina-Elizalde, M., Polanco-Martínez, J. M., Lases-Hernández, F., Bradley, R., \& Burns, S. (2016). Testing the "tropical storm" hypothesis of Yucatan Peninsula climate variability during the Maya Terminal Classic Period. Quaternary Research, 86(2), 111-119. https://doi.org/10.1016/j.yqres.2016.05.006

Moore, T. C., Walker, J. C. G., Rea, D. K., Lewis, C. F. M., Shane, L. C. K., \& Smith, A. J. (2000). Younger Dryas interval and outflow from the Laurentide ice sheet. Paleoceanography, 15(1), 4-18. https://doi.org/10.1029/1999PA000437

Morrill, C., Anderson, D. M., Bauer, B. A., Buckner, R., Gille, E. P., Gross, W. S., Hartman, M., $\&$ Shah, A. (2013). Proxy benchmarks for intercomparison of 8.2 ka simulations. Climate of the Past. https://doi.org/10.5194/cp-9-423-2013

Morrill, C., Legrande, A. N., Renssen, H., Bakker, P., \& Otto-Bliesner, B. L. (2013). Model sensitivity to North Atlantic freshwater forcing at $8.2 \mathrm{ka}$. Climate of the Past. https://doi.org/10.5194/cp-9-955-2013

Oster, J. L., Sharp, W. D., Covey, A. K., Gibson, J., Rogers, B., \& Mix, H. (2017). Climate response to the 8.2 ka event in coastal California. Scientific Reports. https://doi.org/10.1038/s41598-017-04215-5

Paus, A. (2009). Vegetation and environment of the Rødalen alpine area, Central Norway, with emphasis on the early Holocene. Vegetation History and Archaeobotany. https://doi.org/10.1007/s00334-009-0228-4

Roy, P. D., Rivero-Navarrete, A., Sánchez-Zavala, J. L., Beramendi-Orosco, L. E., MuthuSankar, G., \& Lozano-Santacruz, R. (2016). Atlantic Ocean modulated hydroclimate of the subtropical northeastern Mexico since the last glacial maximum and comparison with the southern US. Earth and Planetary Science Letters, 434, 141-150.

https://doi.org/10.1016/j.epsl.2015.11.048 
Scheff, J., Seager, R., Liu, H., \& Coats, S. (2017). Are glacials dry? Consequences for paleoclimatology and for greenhouse warming. Journal of Climate, 30(17), 6593-6609. https://doi.org/10.1175/JCLI-D-16-0854.1

Sinclair, D. J., Banner, J. L., Taylor, F. W., Partin, J., \& Jenson, J. (2012). Magnesium and strontium systematics in tropical speleothems from the Western Pacific. Chemical ....

Steponaitis, E., Andrews, A., McGee, D., Quade, J., Hsieh, Y.-T., Broecker, W. S., Shuman, B. N., Burns, S. J., \& Cheng, H. (2015). Mid-Holocene drying of the U.S. Great Basin recorded in Nevada speleothems. Quaternary Science Reviews, 127, 174-185. https://doi.org/10.1016/j.quascirev.2015.04.011

Stranne, C., Jakobsson, M., \& Björk, G. (2014). Arctic Ocean perennial sea ice breakdown during the Early Holocene Insolation Maximum. Quaternary Science Reviews. https://doi.org/10.1016/j.quascirev.2013.10.022

Teller, J. T., Leverington, D. W., \& Mann, J. D. (2002). Freshwater outbursts to the oceans from glacial Lake Agassiz and their role in climate change during the last deglaciation. Quaternary Science Reviews, 21(8-9), 879-887. https://doi.org/10.1016/S02773791(01)00145-7

Thiagarajan, N., Subhas, A. V., Southon, J. R., Eiler, J. M., \& Adkins, J. F. (2014). Abrupt preBølling-Allerød warming and circulation changes in the deep ocean. Nature, 511(7507), 75-78. https://doi.org/10.1038/nature13472

Thomas, E. R., Wolff, E. W., Mulvaney, R., Steffensen, J. P., Johnsen, S. J., Arrowsmith, C., White, J. W. C., Vaughn, B., \& Popp, T. (2007). The 8.2 ka event from Greenland ice cores. Quaternary Science Reviews. https://doi.org/10.1016/j.quascirev.2006.07.017

Thornalley, D. J. R., Oppo, D. W., Ortega, P., Robson, J. I., Brierley, C. M., Davis, R., Hall, I. R., Moffa-Sanchez, P., Rose, N. L., Spooner, P. T., Yashayaev, I., \& Keigwin, L. D. (2018). Anomalously weak Labrador Sea convection and Atlantic overturning during the past 150 years. Nature. https://doi.org/10.1038/s41586-018-0007-4

Tinner, W., \& Lotter, A. F. (2001). Central European vegetation response to abrupt climate change at $8.2 \mathrm{ka}$. Geology. https://doi.org/10.1130/00917613(2001)029<0551:CEVRTA > 2.0.CO;2

Tremaine, D. M., \& Froelich, P. N. (2013). Speleothem trace element signatures: A hydrologic geochemical study of modern cave dripwaters and farmed calcite. Geochimica et Cosmochimica Acta, 121, 522-545. https://doi.org/10.1016/j.gca.2013.07.026

Vellinga, M., \& Wood, R. A. (2002). Global climatic impacts of a collapse of the atlantic thermohaline circulation. Climatic Change. https://doi.org/10.1023/A:1016168827653

Williams, A. P., Cook, E. R., Smerdon, J. E., Cook, B. I., Abatzoglou, J. T., Bolles, K., Baek, S. H., Badger, A. M., \& Livneh, B. (2020). Large contribution from anthropogenic warming to an emerging North American megadrought. Science, 368(6488), 314-318. https://doi.org/10.1126/science.aaz9600

Wong, C. I., Banner, J. L., \& Musgrove, M. (2015). Holocene climate variability in Texas, USA: An integration of existing paleoclimate data and modeling with a new, high-resolution speleothem record. Quaternary Science Reviews, 127, 155-173. https://doi.org/10.1016/j.quascirev.2015.06.023

Wong, C. I., \& Breecker, D. O. (2015). Advancements in the use of speleothems as climate archives. Quaternary Sci Rev, 127, 1-18. https://doi.org/10.1016/j.quascirev.2015.07.019

Wurster, C. M., Patterson, W. P., McFarlane, D. A., Wassenaar, L. I., Hobson, K. A., Athfield, N. B., \& Bird, M. I. (2008). Stable carbon and hydrogen isotopes from bat guano in the 
Grand Canyon, USA, reveal younger dryas and 8.2 ka events. Geology, 36(9), 683-686. https://doi.org/10.1130/G24938A.1

Wright, K., Johnson, K.R., Serrato Marks, G., McGee, D., Bhattacharya, T., Goldsmith, G., Tabor, C., Lacaille-Muzquiz, J.-L., Lum, G., Beramendi-Orosco, L., Precipitation in Mexico dominated by changes in Atlantic Meridional Overturning Circulation, in prep. for Science Advances.

\section{Appendix A. Figures}

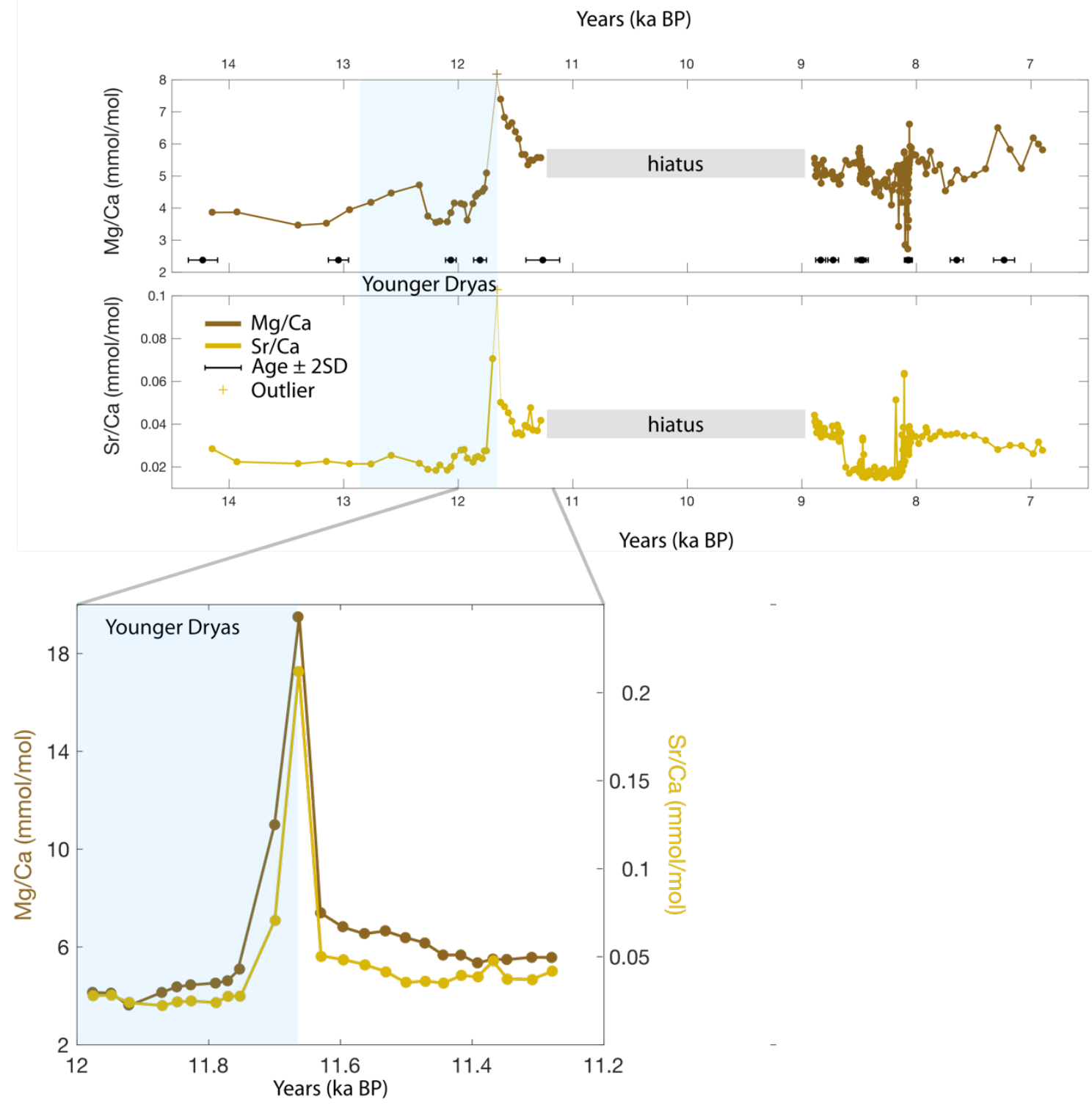

Figure A1. Full extent of current data on trace element to calcium ratios from GC1 (14.18 \pm 0.13 to $6.84 \pm 0.14 \mathrm{ka}$ ). The blue box denotes the Younger Dryas, which occurred from 12.839 
to $11.653 \mathrm{ka}$ (Rasmussen et al., 2006).

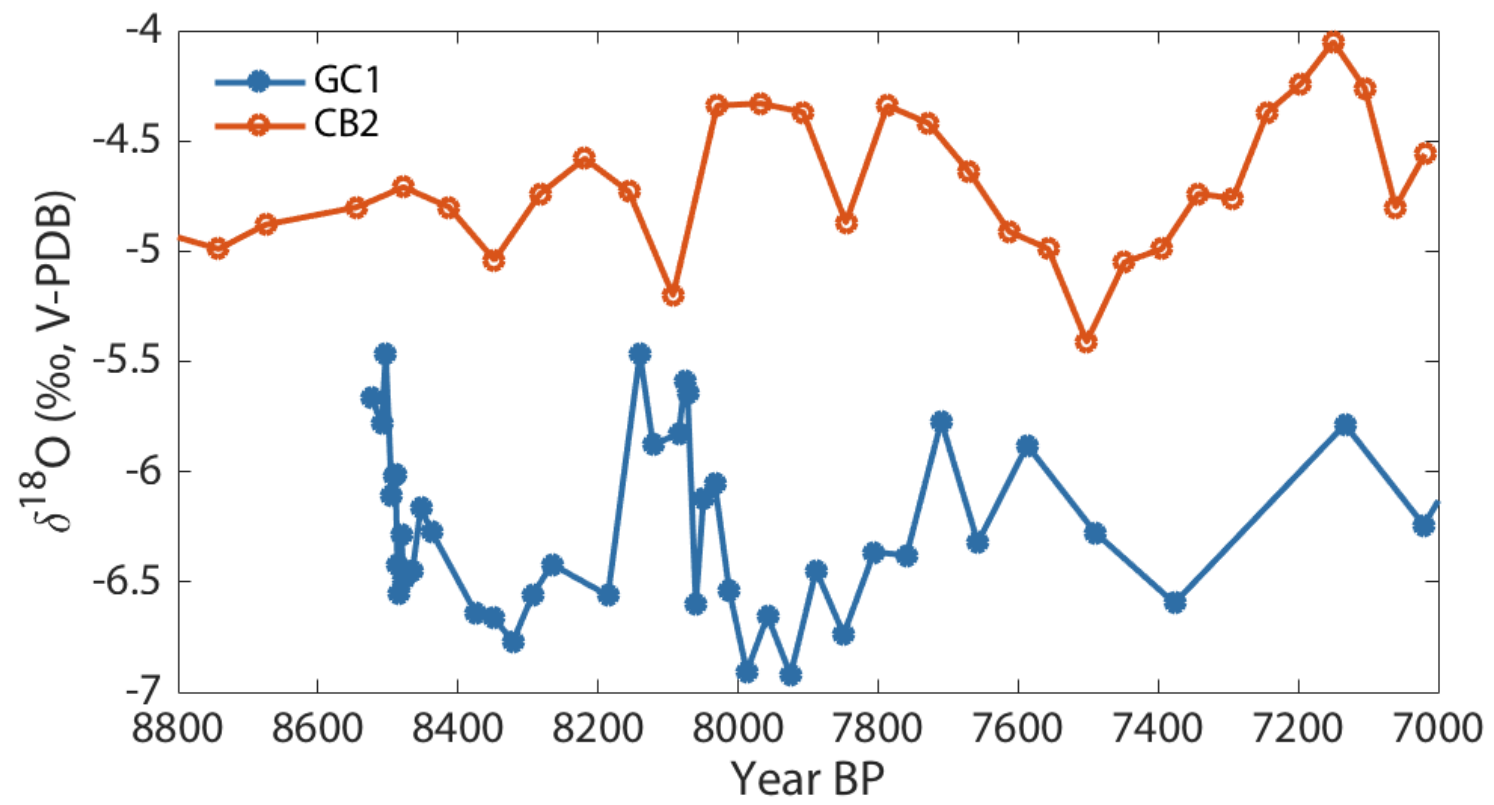

$8.2 \mathrm{ka}$

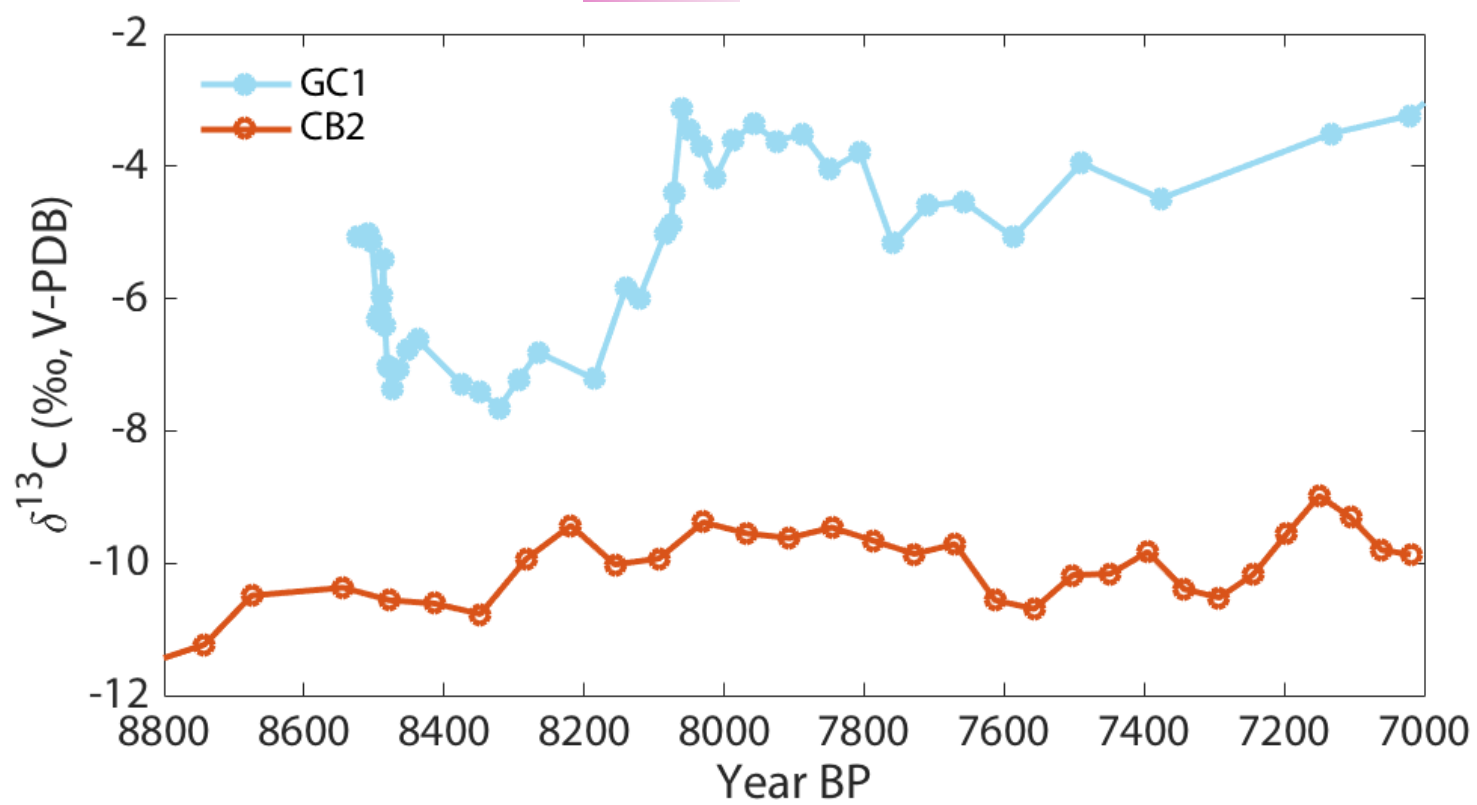

Figure A2. Comparing GC1 and CB2 (Wright et al., in prep.) proxy data over the 8.2 ka event. Due to high uncertainty in the age model for $C B 2$ at this period $(2 S D=2-5 \mathrm{ka}$ ), it's difficult to know whether there is a real signal here. To better compare these two records, we will need to do higher resolution dating and drilling on CB2. 


\section{Appendix B. Data}

Table 1. U-Series data for 18 samples from GC1 based on analyses at MIT between 2017 and 2020, sorted by increasing depth.

\begin{tabular}{|c|c|c|c|c|c|c|c|c|c|c|c|}
\hline Sample ID & $\begin{array}{c}\text { Depth } \\
\mathrm{mm}\end{array}$ & $\begin{array}{l}{ }^{238} \mathrm{U} \\
\mathrm{ng} / \mathrm{g}\end{array}$ & $\begin{array}{c} \pm \\
2 \sigma\end{array}$ & $\begin{array}{c}{ }^{232} \mathrm{Th} \\
\mathrm{pg} / \mathrm{g}\end{array}$ & $\begin{array}{c} \pm \\
2 \sigma\end{array}$ & $\begin{array}{c}\mathbf{d}^{\mathbf{2 3 4}} \mathbf{U} \\
\% 0\end{array}$ & $\begin{array}{c} \pm \\
2 \sigma\end{array}$ & $\begin{array}{c}{ }^{230} \mathrm{Th} / \\
\left.{ }^{238} \mathrm{U}\right) \\
\text { activity }\end{array}$ & $\pm 2 \sigma$ & $\begin{array}{l}{ }^{230} \mathrm{Th} / \\
{ }^{232} \mathrm{Th} \\
\mathrm{ppm} \\
\text { atomic }\end{array}$ & $\begin{array}{c} \pm \\
2 \sigma\end{array}$ \\
\hline GC1 top & 11 & 6.6 & 1.3 & 800 & 16 & 1174.2 & 1.7 & 0.1439 & 0.001 & 190.1 & 1.3 \\
\hline GC1 & $\angle U$ & 111 & 2 & 551 & 11 & 1200.3 & 1.4 & 0.1527 & 0.0009 & 490 & 3 \\
\hline GC1- & 45 & 102 & 2 & 78.2 & 1.8 & 1255.9 & 1.6 & 0.1634 & 0.0006 & 3390 & 40 \\
\hline GC1-2 & 54 & 134 & 3 & 124 & 3 & 1282.7 & 1.6 & 0.1656 & 0.0006 & 2840 & 30 \\
\hline GC1 & 92 & 131 & 3 & 550 & 11 & 1267.2 & 1.6 & 0.1731 & 008 & 656 & 4 \\
\hline GC1 & 2 & 96.2 & 1.9 & 150 & 3 & 1238 & 2 & 5 & 9 & 1734 & 17 \\
\hline GC1-124 & 124 & 122 & 2 & 364 & 7 & 1256 & 3 & 0.1769 & 08 & 944 & 6 \\
\hline GC1-138 & 138 & 148 & 3 & 521 & 11 & 1268.8 & 1.5 & 0.1802 & 0.0007 & 813 & 4 \\
\hline GC1-145 & 145 & 81.2 & 1.6 & 1480 & 30 & 1059.6 & 1.4 & 0.2146 & 0.0009 & 187.4 & 0.7 \\
\hline GC1-3 & 166 & 99.3 & 2 & 441 & 9 & 1123.6 & 1.8 & 0.2223 & 0.0008 & 796 & 3 \\
\hline GC1-4 & 171 & 121 & 2 & 344 & 7 & 1169.8 & 2 & 0.2314 & 0.0007 & 1296 & 5 \\
\hline GC1-183 & 183 & 165 & 3 & 1460 & 30 & 1261.7 & 1.2 & 0.2614 & 0.0011 & 470.6 & 2 \\
\hline GC1-193 & 193 & 122 & 2 & 2210 & 40 & 1213 & 3 & 0.2799 & 0.001 & 245.5 & 0.9 \\
\hline GC1-212 & 212 & 81.9 & 1.6 & 2660 & 50 & 1129.2 & 1.5 & 0.2889 & 0.0013 & 141.4 & 0.7 \\
\hline GC1-230 & 230 & 64.6 & 1.3 & 13300 & 300 & 1125 & 2 & 0.362 & 0.004 & 28 & 0.3 \\
\hline GC1-240 & 240 & 160 & 3 & 1920 & 40 & 1129 & 2 & 0.3171 & 0.0012 & 419.8 & 1.7 \\
\hline GC1-5 & 257 & 82.3 & 1.6 & 8930 & 180 & 1113.7 & 1.5 & 0.386 & 0.003 & 56.5 & 0.4 \\
\hline GC1-270 & 270 & 62.7 & 1.3 & 1230 & 20 & 1059.4 & 1.7 & 0.384 & 0.002 & 311 & 1.8 \\
\hline
\end{tabular}

Table 2. U-Series dates calculated based on data in Table 1. Ages are given as corrected (corr.) and uncorrected (uncorr.); corrected age in years before present (where present is 1950) was used for agedepth modeling. Year of chem. column denotes the year in which chemistry was completed. Data span multiple pages.

\begin{tabular}{|c|c|c|c|c|c|c|c|c|c|}
\hline $\begin{array}{l}\text { Sample } \\
\text { ID }\end{array}$ & $\begin{array}{l}\text { Uncorr. } \\
\text { Age (yr) }\end{array}$ & $\pm 2 \sigma$ & $\begin{array}{l}\text { Corr. } \\
\text { Age } \\
\text { (yr } \\
\text { before } \\
\text { chem.) }\end{array}$ & $\pm 2 \sigma$ & $\underset{\% o}{d^{234}} U_{\%}$ init. & $\pm 2 \sigma$ & $\begin{array}{c}\text { Corr. Age } \\
\text { (yr before } \\
1950 \text { ) }\end{array}$ & $\pm 2 \sigma$ & $\begin{array}{c}\text { Year of } \\
\text { chem. }\end{array}$ \\
\hline GC1 top & 7410 & 50 & 7260 & 100 & 1198.3 & 1.8 & 7190 & 100 & 2017 \\
\hline GC1-20 & 7790 & 50 & 7730 & 60 & 1226.7 & 1.5 & 7660 & 60 & 2020 \\
\hline GC1-1 & 8150 & 30 & 8140 & 30 & 1285.1 & 1.7 & 8070 & 30 & 2018 \\
\hline GC1-2 & 8160 & 30 & 8150 & 30 & 1312.5 & 1.7 & 8080 & 30 & 2018 \\
\hline GC1-92 & 8600 & 40 & 8550 & 50 & 1298.1 & 1.6 & 8480 & 50 & 2020 \\
\hline GC1-112 & 8580 & 50 & 8560 & 50 & 1268 & 2 & 8490 & 50 & 2020 \\
\hline
\end{tabular}




\begin{tabular}{|c|c|c|c|c|c|c|c|c|c|}
\hline GC1-124 & 8840 & 40 & 8800 & 50 & 1288 & 3 & 8730 & 50 & 2020 \\
\hline GC1-138 & 8960 & 40 & 8910 & 40 & 1301 & 1.6 & 8840 & 40 & 2020 \\
\hline GC1-145 & 11890 & 50 & 11630 & 140 & 1094.9 & 1.5 & 11560 & 140 & 2020 \\
\hline GC1-3 & 11950 & 50 & 11880 & 60 & 1161.9 & 1.9 & 11810 & 60 & 2018 \\
\hline GC1-4 & 12180 & 40 & 12140 & 40 & 1211 & 2 & 12070 & 40 & 2018 \\
\hline GC1-183 & 13250 & 60 & 13130 & 80 & 1309.3 & 1.3 & 13060 & 80 & 2020 \\
\hline GC1-193 & 14580 & 60 & 14330 & 130 & 1262 & 3 & 14260 & 130 & 2020 \\
\hline GC1-212 & 15700 & 80 & 15300 & 200 & 1178.7 & 1.8 & 15200 & 200 & 2020 \\
\hline GC1-230 & 20000 & 200 & 17200 & $\begin{array}{c}150 \\
0\end{array}$ & 1180 & 6 & 17100 & 1500 & 2018 \\
\hline GC1-240 & 17350 & 70 & 17180 & 110 & 1185 & 2 & 17110 & 110 & 2020 \\
\hline GC1-5 & 21590 & 160 & 20100 & 800 & 1178 & 3 & 20000 & 800 & 2018 \\
\hline GC1-270 & 22110 & 140 & 21840 & 190 & 1126.7 & 1.9 & 21770 & 190 & 2020 \\
\hline
\end{tabular}

Table 3. Stable isotope and trace element data for GC1. Age is given as year before present, where present is 1950. Data are organized by increasing depth (measured from the top of the stalagmite) and span multiple pages. Missing data are noted with NaN.

\begin{tabular}{|c|c|c|c|c|c|}
\hline $\begin{array}{c}\text { Depth } \\
\text { mm from top }\end{array}$ & $\begin{array}{c}\text { Age } \\
\text { Year BP }\end{array}$ & $\begin{array}{c}\mathrm{Mg} / \mathrm{Ca} \\
\mathrm{mol} / \mathrm{mol}\end{array}$ & $\begin{array}{c}\mathrm{Sr} / \mathrm{Ca} \\
\mathrm{mol} / \mathrm{mol}\end{array}$ & $\begin{array}{c}\mathbf{d}^{13} \mathbf{C} \\
\% \text {, VPDB }\end{array}$ & $\begin{array}{c}\mathbf{d}^{\mathbf{1 8}} \mathbf{O} \\
\% \text {, VPDB }\end{array}$ \\
\hline 2 & 6839 & 5.816E-03 & 2.779E-05 & -3.17 & -5.21 \\
\hline 4 & 6864 & 5.994E-03 & 3.166E-05 & -1.79 & -5.40 \\
\hline 5.5 & 6909 & 6.189E-03 & 2.620E-05 & $\mathrm{NaN}$ & $\mathrm{NaN}$ \\
\hline 8 & 7021 & $5.235 \mathrm{E}-03$ & 2.995E-05 & -3.23 & -6.24 \\
\hline 10 & 7133 & 5.830E-03 & 3.011E-05 & -3.51 & -5.79 \\
\hline 12 & 7256 & $6.505 \mathrm{E}-03$ & $2.812 \mathrm{E}-05$ & $\mathrm{NaN}$ & $\mathrm{NaN}$ \\
\hline 14 & 7377 & $5.224 \mathrm{E}-03$ & 3.247E-05 & -4.49 & -6.60 \\
\hline 16 & 7490 & $5.038 \mathrm{E}-03$ & $3.481 \mathrm{E}-05$ & -3.95 & -6.28 \\
\hline 18 & 7587 & 4.907E-03 & 3.452E-05 & -5.07 & -5.88 \\
\hline 20 & 7658 & $5.187 \mathrm{E}-03$ & 3.568E-05 & -4.54 & -6.32 \\
\hline 22 & 7710 & 4.789E-03 & 3.513E-05 & -4.59 & -5.77 \\
\hline 24 & 7759 & $4.538 \mathrm{E}-03$ & 3.486E-05 & -5.17 & -6.38 \\
\hline 26 & 7806 & $5.350 \mathrm{E}-03$ & 3.638E-05 & -3.80 & -6.37 \\
\hline 28 & 7849 & 5.169E-03 & 3.442E-05 & -4.05 & -6.74 \\
\hline 30 & 7889 & 5.770E-03 & 3.312E-05 & -3.50 & -6.45 \\
\hline 31.5 & 7916 & 5.317E-03 & 3.667E-05 & $\mathrm{NaN}$ & $\mathrm{NaN}$ \\
\hline 31.5 & 7916 & $5.381 \mathrm{E}-03$ & 3.620E-05 & $\mathrm{NaN}$ & $\mathrm{NaN}$ \\
\hline 32 & 7925 & $5.065 \mathrm{E}-03$ & 3.839E-05 & -3.63 & -6.92 \\
\hline 34 & 7958 & $5.515 \mathrm{E}-03$ & $3.417 \mathrm{E}-05$ & -3.36 & -6.65 \\
\hline 36 & 7988 & 5.448E-03 & 3.095E-05 & -3.61 & -6.91 \\
\hline 38 & 8013 & 5.652E-03 & 3.420E-05 & -4.18 & -6.54 \\
\hline
\end{tabular}




\begin{tabular}{|c|c|c|c|c|c|}
\hline 40 & 8033 & 5.681E-03 & 3.439E-05 & -3.70 & -6.05 \\
\hline 42 & 8049 & 5.881E-03 & 3.586E-05 & -3.45 & -6.12 \\
\hline 43 & 8055 & 5.590E-03 & 3.158E-05 & $\mathrm{NaN}$ & $\mathrm{NaN}$ \\
\hline 44 & 8060 & 5.923E-03 & 3.562E-05 & -3.14 & -6.60 \\
\hline 45 & 8064 & 5.456E-03 & 3.650E-05 & $\mathrm{NaN}$ & $\mathrm{NaN}$ \\
\hline 45.5 & 8066 & 6.617E-03 & 3.895E-05 & $\mathrm{NaN}$ & $\mathrm{NaN}$ \\
\hline 46 & 8067 & 5.351E-03 & 3.743E-05 & $\mathrm{NaN}$ & $\mathrm{NaN}$ \\
\hline 46.5 & 8069 & 4.622E-03 & 3.176E-05 & $\mathrm{NaN}$ & $\mathrm{NaN}$ \\
\hline 47 & 8070 & 5.216E-03 & 2.992E-05 & $\mathrm{NaN}$ & $\mathrm{NaN}$ \\
\hline 47.5 & 8071 & 5.104E-03 & 2.571E-05 & $\mathrm{NaN}$ & $\mathrm{NaN}$ \\
\hline 48 & 8072 & 5.284E-03 & 3.044E-05 & -4.40 & -5.64 \\
\hline 48.5 & 8073 & 3.628E-03 & 2.775E-05 & $\mathrm{NaN}$ & $\mathrm{NaN}$ \\
\hline 49 & 8074 & 5.541E-03 & 2.712E-05 & $\mathrm{NaN}$ & $\mathrm{NaN}$ \\
\hline 49 & 8074 & 5.482E-03 & 2.778E-05 & $\mathrm{NaN}$ & $\mathrm{NaN}$ \\
\hline 49.5 & 8075 & 5.110E-03 & 2.787E-05 & $\mathrm{NaN}$ & $\mathrm{NaN}$ \\
\hline 50 & 8076 & 4.877E-03 & 2.873E-05 & -4.89 & -5.59 \\
\hline 50.5 & 8077 & 4.203E-03 & 2.885E-05 & $\mathrm{NaN}$ & $\mathrm{NaN}$ \\
\hline 51 & 8078 & 5.045E-03 & 3.345E-05 & $\mathrm{NaN}$ & $\mathrm{NaN}$ \\
\hline 51.5 & 8079 & 3.394E-03 & 2.984E-05 & $\mathrm{NaN}$ & $\mathrm{NaN}$ \\
\hline 52 & 8080 & 2.727E-03 & 2.967E-05 & $\mathrm{NaN}$ & $\mathrm{NaN}$ \\
\hline 52.5 & 8081 & 4.786E-03 & 3.145E-05 & $\mathrm{NaN}$ & $\mathrm{NaN}$ \\
\hline 53 & 8082 & 4.719E-03 & $2.765 \mathrm{E}-05$ & $\mathrm{NaN}$ & $\mathrm{NaN}$ \\
\hline 53.5 & 8083 & 4.423E-03 & $2.841 \mathrm{E}-05$ & $\mathrm{NaN}$ & $\mathrm{NaN}$ \\
\hline 54 & 8085 & 4.420E-03 & 3.274E-05 & -5.03 & -5.83 \\
\hline 54.5 & 8086 & 4.619E-03 & 2.785E-05 & $\mathrm{NaN}$ & $\mathrm{NaN}$ \\
\hline 55 & 8088 & 5.112E-03 & 2.985E-05 & $\mathrm{NaN}$ & $\mathrm{NaN}$ \\
\hline 55.5 & 8090 & 3.801E-03 & 3.173E-05 & $\mathrm{NaN}$ & $\mathrm{NaN}$ \\
\hline 56 & 8093 & 4.420E-03 & 3.274E-05 & $\mathrm{NaN}$ & $\mathrm{NaN}$ \\
\hline 57 & 8098 & 4.743E-03 & 2.945E-05 & $\mathrm{NaN}$ & $\mathrm{NaN}$ \\
\hline 57.5 & 8102 & 2.863E-03 & 2.801E-05 & $\mathrm{NaN}$ & $\mathrm{NaN}$ \\
\hline 58 & 8105 & 2.849E-03 & 2.266E-05 & $\mathrm{NaN}$ & $\mathrm{NaN}$ \\
\hline 58.5 & 8109 & 4.923E-03 & $2.275 \mathrm{E}-05$ & $\mathrm{NaN}$ & $\mathrm{NaN}$ \\
\hline 59 & 8113 & 5.720E-03 & 6.324E-05 & $\mathrm{NaN}$ & $\mathrm{NaN}$ \\
\hline 59 & 8113 & 5.756E-03 & 6.379E-05 & $\mathrm{NaN}$ & $\mathrm{NaN}$ \\
\hline 59.5 & 8117 & 4.998E-03 & 2.079E-05 & $\mathrm{NaN}$ & $\mathrm{NaN}$ \\
\hline 60 & 8121 & 5.362E-03 & 3.856E-05 & -6.00 & -5.88 \\
\hline 60.5 & 8126 & 5.083E-03 & 2.795E-05 & $\mathrm{NaN}$ & $\mathrm{NaN}$ \\
\hline 61 & 8131 & 5.242E-03 & 1.813E-05 & $\mathrm{NaN}$ & $\mathrm{NaN}$ \\
\hline 61 & 8131 & 5.217E-03 & 1.803E-05 & $\mathrm{NaN}$ & $\mathrm{NaN}$ \\
\hline
\end{tabular}




\begin{tabular}{|c|c|c|c|c|c|}
\hline 61.5 & 8135 & 4.178E-03 & 3.498E-05 & $\mathrm{NaN}$ & $\mathrm{NaN}$ \\
\hline 62 & 8140 & 5.153E-03 & 2.066E-05 & -5.83 & -5.46 \\
\hline 62.5 & 8145 & 4.553E-03 & 2.114E-05 & $\mathrm{NaN}$ & $\mathrm{NaN}$ \\
\hline 62.5 & 8145 & 4.548E-03 & 2.144E-05 & $\mathrm{NaN}$ & $\mathrm{NaN}$ \\
\hline 63 & 8151 & 5.322E-03 & 1.622E-05 & $\mathrm{NaN}$ & $\mathrm{NaN}$ \\
\hline 63.5 & 8156 & 4.522E-03 & 1.890E-05 & $\mathrm{NaN}$ & $\mathrm{NaN}$ \\
\hline 63.5 & 8156 & $4.528 \mathrm{E}-03$ & 1.895E-05 & $\mathrm{NaN}$ & $\mathrm{NaN}$ \\
\hline 64 & 8162 & 3.427E-03 & 1.686E-05 & $\mathrm{NaN}$ & $\mathrm{NaN}$ \\
\hline 64.5 & 8168 & 5.088E-03 & 1.861E-05 & $\mathrm{NaN}$ & $\mathrm{NaN}$ \\
\hline 65 & 8174 & 5.328E-03 & $1.541 \mathrm{E}-05$ & $\mathrm{NaN}$ & $\mathrm{NaN}$ \\
\hline 66 & 8186 & 5.184E-03 & $5.138 \mathrm{E}-05$ & -7.21 & -6.56 \\
\hline 67 & 8198 & 4.737E-03 & 1.529E-05 & $\mathrm{NaN}$ & $\mathrm{NaN}$ \\
\hline 68.5 & 8218 & 4.555E-03 & 1.851E-05 & $\mathrm{NaN}$ & $\mathrm{NaN}$ \\
\hline 69 & 8224 & 4.098E-03 & 1.815E-05 & $\mathrm{NaN}$ & $\mathrm{NaN}$ \\
\hline 70.5 & 8245 & 5.115E-03 & 1.705E-05 & $\mathrm{NaN}$ & $\mathrm{NaN}$ \\
\hline 72 & 8266 & 4.670E-03 & 1.707E-05 & -6.81 & -6.42 \\
\hline 73 & 8280 & 4.891E-03 & 1.629E-05 & $\mathrm{NaN}$ & $\mathrm{NaN}$ \\
\hline 74 & 8294 & 4.840E-03 & 1.912E-05 & -7.23 & -6.56 \\
\hline 75 & 8308 & 4.775E-03 & 1.484E-05 & $\mathrm{NaN}$ & $\mathrm{NaN}$ \\
\hline 76 & 8322 & 4.377E-03 & 1.816E-05 & -7.65 & -6.77 \\
\hline 78 & 8349 & 4.669E-03 & 1.712E-05 & -7.40 & -6.66 \\
\hline 78 & 8349 & $4.651 \mathrm{E}-03$ & 1.665E-05 & -7.40 & -6.66 \\
\hline 79 & 8362 & 4.815E-03 & 1.509E-05 & $\mathrm{NaN}$ & $\mathrm{NaN}$ \\
\hline 80 & 8375 & 4.491E-03 & 1.994E-05 & -7.29 & -6.64 \\
\hline 82.5 & 8404 & 5.109E-03 & 1.668E-05 & $\mathrm{NaN}$ & $\mathrm{NaN}$ \\
\hline 84.5 & 8425 & 5.060E-03 & 1.816E-05 & $\mathrm{NaN}$ & $\mathrm{NaN}$ \\
\hline 85 & 8429 & 5.213E-03 & 1.616E-05 & $\mathrm{NaN}$ & $\mathrm{NaN}$ \\
\hline 85 & 8429 & 5.124E-03 & 1.601E-05 & $\mathrm{NaN}$ & $\mathrm{NaN}$ \\
\hline 86 & 8438 & $5.175 \mathrm{E}-03$ & 1.672E-05 & -6.62 & -6.27 \\
\hline 87 & 8446 & 4.762E-03 & 1.702E-05 & $\mathrm{NaN}$ & $\mathrm{NaN}$ \\
\hline 88 & 8453 & 4.962E-03 & 1.509E-05 & -6.78 & -6.16 \\
\hline 89 & 8460 & 4.930E-03 & 1.559E-05 & $\mathrm{NaN}$ & $\mathrm{NaN}$ \\
\hline 90 & 8465 & 4.965E-03 & 1.563E-05 & -7.06 & -6.45 \\
\hline 91 & 8469 & 4.930E-03 & 2.580E-05 & $\mathrm{NaN}$ & $\mathrm{NaN}$ \\
\hline 92 & 8473 & 5.016E-03 & 1.790E-05 & -7.36 & -6.46 \\
\hline 94 & 8477 & 5.006E-03 & 3.251E-05 & -7.04 & -6.49 \\
\hline 94 & 8477 & 4.934E-03 & 3.358E-05 & $\mathrm{NaN}$ & $\mathrm{NaN}$ \\
\hline 95 & 8479 & 5.094E-03 & 1.545E-05 & $\mathrm{NaN}$ & $\mathrm{NaN}$ \\
\hline 96 & 8481 & 4.810E-03 & 1.705E-05 & -7.02 & -6.28 \\
\hline
\end{tabular}




\begin{tabular}{|c|c|c|c|c|c|}
\hline 97 & 8483 & 5.192E-03 & 1.628E-05 & $\mathrm{NaN}$ & $\mathrm{NaN}$ \\
\hline 98 & 8484 & 5.353E-03 & 1.687E-05 & -6.42 & -6.55 \\
\hline 100 & 8487 & 5.206E-03 & 1.853E-05 & -5.40 & -6.42 \\
\hline 101 & 8488 & 5.239E-03 & 1.925E-05 & $\mathrm{NaN}$ & $\mathrm{NaN}$ \\
\hline 102 & 8489 & 5.481E-03 & 1.714E-05 & -5.96 & -6.01 \\
\hline 103 & 8490 & 4.944E-03 & 2.271E-05 & $\mathrm{NaN}$ & $\mathrm{NaN}$ \\
\hline 104 & 8492 & 5.059E-03 & 1.974E-05 & -6.21 & -6.02 \\
\hline 106 & 8495 & 5.301E-03 & $2.050 \mathrm{E}-05$ & -6.31 & -6.11 \\
\hline 107 & 8497 & 4.946E-03 & 2.166E-05 & $\mathrm{NaN}$ & $\mathrm{NaN}$ \\
\hline 107 & 8497 & $4.881 \mathrm{E}-03$ & $2.135 \mathrm{E}-05$ & $\mathrm{NaN}$ & $\mathrm{NaN}$ \\
\hline 109 & 8501 & 5.615E-03 & 1.898E-05 & $\mathrm{NaN}$ & $\mathrm{NaN}$ \\
\hline 109.5 & 8502 & 5.867E-03 & 1.775E-05 & $\mathrm{NaN}$ & $\mathrm{NaN}$ \\
\hline 110 & 8503 & 5.746E-03 & 1.745E-05 & -5.14 & -5.47 \\
\hline 112 & 8509 & 5.723E-03 & 1.862E-05 & -5.03 & -5.78 \\
\hline 114 & 8524 & 5.435E-03 & 1.902E-05 & -5.06 & -5.67 \\
\hline 115 & 8537 & 5.402E-03 & 1.893E-05 & $\mathrm{NaN}$ & $\mathrm{NaN}$ \\
\hline 116 & 8552 & 5.407E-03 & 1.860E-05 & $\mathrm{NaN}$ & $\mathrm{NaN}$ \\
\hline 118 & 8590 & 5.355E-03 & 1.705E-05 & $\mathrm{NaN}$ & $\mathrm{NaN}$ \\
\hline 119.5 & 8620 & 5.487E-03 & 1.986E-05 & $\mathrm{NaN}$ & $\mathrm{NaN}$ \\
\hline 121.5 & 8660 & 5.016E-03 & 3.601E-05 & $\mathrm{NaN}$ & $\mathrm{NaN}$ \\
\hline 122 & 8669 & 4.759E-03 & 3.232E-05 & $\mathrm{NaN}$ & NaN \\
\hline 122.5 & 8678 & 4.742E-03 & 3.197E-05 & $\mathrm{NaN}$ & $\mathrm{NaN}$ \\
\hline 123 & 8687 & 4.959E-03 & 3.820E-05 & $\mathrm{NaN}$ & $\mathrm{NaN}$ \\
\hline 123.5 & 8694 & 4.922E-03 & 3.965E-05 & $\mathrm{NaN}$ & $\mathrm{NaN}$ \\
\hline 124 & 8701 & 4.907E-03 & $3.514 \mathrm{E}-05$ & $\mathrm{NaN}$ & $\mathrm{NaN}$ \\
\hline 126 & 8726 & 4.998E-03 & 3.427E-05 & $\mathrm{NaN}$ & $\mathrm{NaN}$ \\
\hline 126 & 8726 & 4.908E-03 & 3.397E-05 & $\mathrm{NaN}$ & $\mathrm{NaN}$ \\
\hline 127 & 8738 & 5.131E-03 & 3.909E-05 & $\mathrm{NaN}$ & $\mathrm{NaN}$ \\
\hline 128 & 8750 & 5.067E-03 & $3.418 \mathrm{E}-05$ & $\mathrm{NaN}$ & $\mathrm{NaN}$ \\
\hline 132 & 8795 & 5.043E-03 & $3.508 \mathrm{E}-05$ & $\mathrm{NaN}$ & $\mathrm{NaN}$ \\
\hline 133 & 8805 & 5.174E-03 & 3.808E-05 & $\mathrm{NaN}$ & $\mathrm{NaN}$ \\
\hline 133 & 8805 & $5.030 \mathrm{E}-03$ & 3.777E-05 & $\mathrm{NaN}$ & $\mathrm{NaN}$ \\
\hline 134 & 8815 & 5.494E-03 & 3.804E-05 & $\mathrm{NaN}$ & $\mathrm{NaN}$ \\
\hline 136 & 8835 & 4.777E-03 & 3.392E-05 & $\mathrm{NaN}$ & $\mathrm{NaN}$ \\
\hline 138 & 8852 & 5.351E-03 & 4.043E-05 & $\mathrm{NaN}$ & $\mathrm{NaN}$ \\
\hline 139 & 8860 & 5.086E-03 & 3.811E-05 & $\mathrm{NaN}$ & $\mathrm{NaN}$ \\
\hline 140 & 8867 & 5.076E-03 & 3.603E-05 & $\mathrm{NaN}$ & $\mathrm{NaN}$ \\
\hline 141 & 8873 & 5.194E-03 & 3.598E-05 & $\mathrm{NaN}$ & $\mathrm{NaN}$ \\
\hline 142 & 8879 & 4.981E-03 & 3.919E-05 & $\mathrm{NaN}$ & $\mathrm{NaN}$ \\
\hline
\end{tabular}




\begin{tabular}{|c|c|c|c|c|c|}
\hline 143 & 8884 & 5.076E-03 & 4.187E-05 & $\mathrm{NaN}$ & $\mathrm{NaN}$ \\
\hline 144 & 8889 & 5.461E-03 & 4.115E-05 & $\mathrm{NaN}$ & $\mathrm{NaN}$ \\
\hline 145 & 8892 & 5.554E-03 & 4.422E-05 & $\mathrm{NaN}$ & $\mathrm{NaN}$ \\
\hline 146 & hiatus & hiatus & hiatus & hiatus & hiatus \\
\hline 147 & 11563 & 5.571E-03 & 4.180E-05 & $\mathrm{NaN}$ & $\mathrm{NaN}$ \\
\hline 149 & 11570 & 5.576E-03 & 3.695E-05 & $\mathrm{NaN}$ & $\mathrm{NaN}$ \\
\hline 151 & 11583 & 5.489E-03 & 3.724E-05 & $\mathrm{NaN}$ & $\mathrm{NaN}$ \\
\hline 152 & 11591 & 5.501E-03 & 4.771E-05 & $\mathrm{NaN}$ & $\mathrm{NaN}$ \\
\hline 153 & 11600 & 5.353E-03 & 3.861E-05 & $\mathrm{NaN}$ & $\mathrm{NaN}$ \\
\hline 154 & 11611 & 5.669E-03 & 3.942E-05 & $\mathrm{NaN}$ & $\mathrm{NaN}$ \\
\hline 155 & 11622 & 5.672E-03 & $3.501 \mathrm{E}-05$ & $\mathrm{NaN}$ & $\mathrm{NaN}$ \\
\hline 156 & 11635 & 6.160E-03 & 3.605E-05 & $\mathrm{NaN}$ & $\mathrm{NaN}$ \\
\hline 157 & 11648 & 6.380E-03 & 3.548E-05 & $\mathrm{NaN}$ & $\mathrm{NaN}$ \\
\hline 158 & 11663 & 6.659E-03 & 4.137E-05 & $\mathrm{NaN}$ & $\mathrm{NaN}$ \\
\hline 159 & 11679 & 6.551E-03 & 4.535E-05 & $\mathrm{NaN}$ & $\mathrm{NaN}$ \\
\hline 160 & 11695 & 6.862E-03 & 4.823E-05 & $\mathrm{NaN}$ & $\mathrm{NaN}$ \\
\hline 161 & 11712 & 7.397E-03 & 5.019E-05 & $\mathrm{NaN}$ & $\mathrm{NaN}$ \\
\hline 162 & 11730 & 1.951E-02 & $2.115 \mathrm{E}-04$ & $\mathrm{NaN}$ & $\mathrm{NaN}$ \\
\hline 163 & 11748 & 1.103E-02 & 7.051E-05 & $\mathrm{NaN}$ & $\mathrm{NaN}$ \\
\hline 164 & 11768 & 5.994E-03 & 2.722E-05 & $\mathrm{NaN}$ & $\mathrm{NaN}$ \\
\hline 164.5 & 11778 & 5.095E-03 & $2.761 \mathrm{E}-05$ & $\mathrm{NaN}$ & $\mathrm{NaN}$ \\
\hline 165 & 11788 & 4.618E-03 & $2.752 \mathrm{E}-05$ & $\mathrm{NaN}$ & $\mathrm{NaN}$ \\
\hline 165.5 & 11799 & $4.522 \mathrm{E}-03$ & 2.394E-05 & $\mathrm{NaN}$ & $\mathrm{NaN}$ \\
\hline 166 & 11810 & 4.866E-03 & 2.170E-05 & $\mathrm{NaN}$ & $\mathrm{NaN}$ \\
\hline 166.5 & 11823 & 4.453E-03 & 2.490E-05 & $\mathrm{NaN}$ & $\mathrm{NaN}$ \\
\hline 167 & 11841 & 4.369E-03 & 2.437E-05 & $\mathrm{NaN}$ & $\mathrm{NaN}$ \\
\hline 167.5 & 11863 & 4.141E-03 & 2.228E-05 & $\mathrm{NaN}$ & $\mathrm{NaN}$ \\
\hline 168 & 11888 & 4.138E-03 & 2.171E-05 & $\mathrm{NaN}$ & $\mathrm{NaN}$ \\
\hline 168.5 & 11915 & 3.627E-03 & 2.406E-05 & $\mathrm{NaN}$ & $\mathrm{NaN}$ \\
\hline 169 & 11945 & 4.111E-03 & 2.815E-05 & $\mathrm{NaN}$ & $\mathrm{NaN}$ \\
\hline 169.5 & 11976 & 4.143E-03 & $2.786 \mathrm{E}-05$ & $\mathrm{NaN}$ & $\mathrm{NaN}$ \\
\hline 170 & 12007 & 4.114E-03 & 2.868E-05 & $\mathrm{NaN}$ & $\mathrm{NaN}$ \\
\hline 170.5 & 12039 & 4.159E-03 & 2.503E-05 & $\mathrm{NaN}$ & $\mathrm{NaN}$ \\
\hline 171 & 12070 & 3.857E-03 & 2.013E-05 & $\mathrm{NaN}$ & $\mathrm{NaN}$ \\
\hline 171.5 & 12101 & 3.574E-03 & 1.849E-05 & $\mathrm{NaN}$ & $\mathrm{NaN}$ \\
\hline 172 & 12134 & 3.486E-03 & 1.759E-05 & $\mathrm{NaN}$ & $\mathrm{NaN}$ \\
\hline 172.5 & 12167 & 3.591E-03 & 2.090E-05 & $\mathrm{NaN}$ & $\mathrm{NaN}$ \\
\hline 173 & 12202 & $3.555 \mathrm{E}-03$ & 1.841E-05 & $\mathrm{NaN}$ & $\mathrm{NaN}$ \\
\hline 174 & 12273 & 3.748E-03 & 1.889E-05 & $\mathrm{NaN}$ & $\mathrm{NaN}$ \\
\hline
\end{tabular}




\begin{tabular}{|l|l|l|l|l|l|}
\hline 175 & 12348 & $4.717 \mathrm{E}-03$ & $2.168 \mathrm{E}-05$ & $\mathrm{NaN}$ & $\mathrm{NaN}$ \\
\hline 178 & 12595 & $4.474 \mathrm{E}-03$ & $2.536 \mathrm{E}-05$ & $\mathrm{NaN}$ & $\mathrm{NaN}$ \\
\hline 180 & 12773 & $4.181 \mathrm{E}-03$ & $2.140 \mathrm{E}-05$ & $\mathrm{NaN}$ & $\mathrm{NaN}$ \\
\hline 182 & 12961 & $3.954 \mathrm{E}-03$ & $2.149 \mathrm{E}-05$ & $\mathrm{NaN}$ & $\mathrm{NaN}$ \\
\hline 184 & 13166 & $3.533 \mathrm{E}-03$ & $2.261 \mathrm{E}-05$ & $\mathrm{NaN}$ & $\mathrm{NaN}$ \\
\hline 186 & 13417 & $3.474 \mathrm{E}-03$ & $2.157 \mathrm{E}-05$ & $\mathrm{NaN}$ & $\mathrm{NaN}$ \\
\hline 190 & 13958 & $3.879 \mathrm{E}-03$ & $2.241 \mathrm{E}-05$ & $\mathrm{NaN}$ & $\mathrm{NaN}$ \\
\hline 192 & 14178 & $3.869 \mathrm{E}-03$ & $2.852 \mathrm{E}-05$ & $\mathrm{NaN}$ & $\mathrm{NaN}$ \\
\hline
\end{tabular}




\section{Chapter 5: Conclusion}

In this thesis, I have presented three speleothem records spanning three snapshots of time, from the Common Era to the deglaciation. Each speleothem may individually capture a short period, but together and in comparison with previously published work, they are informative about Mexican paleoclimate. The new records from Mexico, especially from the Mexican arid zone, are timely: a recent IPCC special report noted high confidence in predictions of increased risk to humans due to desertification in the coming decades (Mirzabaev et al., 2019), which includes water stress and drought intensity. Despite these predictions, we still lack information

on adaptation to drying and desertification in dry environments (Mirzabaev et al., 2019). I would argue that the chapters in this thesis show that Mexico is sensitive to drought and needs to prepare for dry conditions in the future, but also that people have the capability to be resilient to changing climate - for example, during the Early Classic (300 - 500 CE) droughts in San Luis Potosi (Chapter 3), or other droughts from 200 to 500 CE in the Yucatan (Douglas et al., 2015). I hope that developing these paleoclimate records and broadening understanding of the range of climate events and states that have occurred in the past few thousand years can provide inspiration and hope to present and future researchers, whose skills will be required to address the climate crisis.

\section{Learning from the past}

The paleoclimate archive, especially in the Holocene, holds valuable data on how human civilizations have responded to adversity, both climate-driven and otherwise (Douglas et al., 2015; Hellin et al., 2014; Lachniet et al., 2017; Mardero et al., 2015; Plunket \& Uruñuela, 2006). As long as humans have existed, we have faced challenging weather and climate. Of course, our present climate crisis is different in rate, severity, and cause, but we can be certain that it will necessitate change in society, from food and water systems to engineering and architecture.

When we look into the paleoclimate archive and find, for example, major precipitation decreases that lasted for decades (Chapter 3), we don't always have a clear sense of how society changed in direct response to those environmental shifts, especially before historical (written, artistic, etc.) records. However, we can generally tell that civilization continued, at the very least. In many cases, the archaeological record has examples of human ingenuity, of engineering 
solutions developed to adapt to the environment, from the same period. In some regions, a basic sense of the engineering solutions has developed without a complete understanding of the climate and environment that necessitated those changes, such as Teotihuacan; while it is clear that the residents of Teotihuacan had water management systems in place, we lack local data on paleohydrology (Mejía Ramón \& Johnson, 2019). Furthermore, some civilizations have received more "credit" than others - historical hydrologists note aqueducts in Rome that were completed in $100 \mathrm{CE}$ (Bono \& Boni, 1996), but not the flood management systems of Teotihuacan and ancient Maya sites that existed at the same time (Douglas et al., 2015; Mejía Ramón \& Johnson, 2019).

\section{Preparing for future droughts}

Given that $60 \%$ of Mexico is classified as drylands and is highly vulnerable to desertification (Mirzabaev et al., 2019), it is important for Mexico (and the rest of North America) to prepare for increased drought intensity under anthropogenic climate change. The impact of droughts will have a disproportionate impact on low-income, marginalized groups, who also have limited capacity to fund climate adaptation initiatives. For example, maize, a staple crop for small farms in Central America, is generally grown under rain-fed conditions and is therefore highly vulnerable to changes in precipitation (Hellin et al., 2014); rainfed maize production is closely correlated with precipitation (Murray-Tortarolo et al., 2018). In northeast Mexico, agricultural yield is predicted to decrease by $30 \%$ under some emissions scenarios (Murray-Tortarolo et al., 2018). It is important to prepare for droughts and prevent land degradation, which is more cost-effective than responding to extreme events and restoring land after it has degraded (Mirzabaev et al., 2019).

One way for northern Mexico to prepare for desertification is to improve rainwater harvesting and water management (Mirzabaev et al., 2019). To do that effectively, there needs to be a robust modern network of precipitation monitoring systems. We - meaning climate scientists - refer to the instrumental period as if it is a clearly defined time when all locations suddenly began to record every possible environmental variable in the exact same way. But even today, weather stations are not evenly distributed within or among countries. In much of Mexico, the current GPCC station density is equivalent to that of the US ( $>50$ stations per 2.5-degree grid box), but the stations are newer and data are sometimes sparse. The San Luis Potosi station, for example, only has $\sim 30$ years of data from 1951 to 2010, despite being located in the state capital. 
I have demonstrated in this thesis that there is a high degree of spatial variability in Mexican precipitation over the Common Era, so it is important to have high-resolution modern data to allow for specific forecasts on multiple timescales. That is part of the reason for establishing local rainfall monitoring programs, with residents of Rioverde (Chapter 4) and Alta Cima (Wright et al., in prep.) being compensated for collecting precipitation samples. With better modern data on precipitation, policymakers will be able to choose the most impactful sites for water management projects. Future studies can provide even more benefit to communities by funding research-grade weather stations for schools, small farms, and municipal buildings, as well as training in how to evaluate these data or provide them to larger agencies.

\section{Next steps}

I suggest that future research in this region focuses on extending the high-resolution (subdecadal) record of northern Mexican precipitation beyond tree ring data (Stahle et al., 2011, 2016) in order to further clarify differing spatial patterns and the drivers behind them.

Furthermore, research would benefit from collaborations that seek to compare or merge data from multiple types of archives. Annual, or even seasonal, paleoclimate data will help to create better benchmarks for validating climate models.

More broadly, I hope that more US-based climate scientists, focusing on both modern and ancient climate change, will pursue an improved understanding of Mexican climate, ideally as collaborative studies with Mexican researchers. Droughts and water stress won't stay confined to one side of a political border, so our research and collaborations shouldn't, either. 


\section{References}

Bono, P., \& Boni, C. (1996). Water supply of Rome in antiquity and today. Environmental Geology, 27(2), 126-134. https://doi.org/10.1007/BF01061685

Douglas, P. M. J., Pagani, M., Canuto, M. A., Brenner, M., Hodell, D. A., Eglinton, T. I., \& Curtis, J. H. (2015). Drought, agricultural adaptation, and sociopolitical collapse in the Maya Lowlands. Proceedings of the National Academy of Sciences of the United States of America, 112(18), 5607-5612. https://doi.org/10.1073/pnas.1419133112

Hellin, J., Bellon, M. R., \& Hearne, S. J. (2014). Maize landraces and adaptation to climate change in Mexico. Journal of Crop Improvement, 28, 484-501. https://doi.org/10.1080/15427528.2014.921800

Lachniet, M. S., Asmerom, Y., Polyak, V., \& Bernal, J. P. (2017). Two millennia of Mesoamerican monsoon variability driven by Pacific and Atlantic synergistic forcing. Quaternary Science Reviews, 155, 100-113. https://doi.org/10.1016/j.quascirev.2016.11.012

Mardero, S., Schmook, B., Radel, C., Christman, Z., Lawrence, D., Millones, M., Nickl, E., Rogan, J., \& Schneider, L. (2015). Smallholders adaptations to droughts and climatic variability in southeastern Mexico. Environmental Hazards, 14(4), 271-288. https://doi.org/10.1080/17477891.2015.1058741

Mejía Ramón, A. G., \& Johnson, N. E. (2019). Sociopolitical organization, landscape change, and hydraulic engineering in the Teotihuacan Valley, Mexico: 1250 B.C.-A.D. 1810. Wiley Interdisciplinary Reviews: Water, 6(2), e1335. https://doi.org/10.1002/wat2.1335

Mirzabaev, A., Wu, J., Evans, J., García-Oliva, F., Hussein, I. A. G., Iqbal, M. H., Kimutai, J., Knowles, T., Meza, F., Nedjraoui, D., Tena, F., Türkeş, M., Vázquez, R. J., \& Weltz, M. (2019). Desertification. In P. R. Shukla, J. Skea, E. C. Buendia, V. Masson-Delmotte, H.-O. Pörtner et al. (Eds.), Climate Change and Land: an IPCC special report on climate change, desertification, land degradation, sustainable land management, food security, and greenhouse gas fluxes in terrestrial ecosystems. https://doi.org/10.4337/9781784710644

Murray-Tortarolo, G. N., Jaramillo, V. J., \& Larsen, J. (2018). Food security and climate change: the case of rainfed maize production in Mexico. Agricultural and Forest Meteorology, 253254, 124-131. https://doi.org/10.1016/j.agrformet.2018.02.011

Plunket, P., \& Uruñuela, G. (2006). Social and cultural consequences of a late Holocene eruption of Popocatépetl in central Mexico. Quaternary International, 151(1), 19-28. https://doi.org/10.1016/j.quaint.2006.01.012

Stahle, D. W., Diaz, J. V., Burnette, D. J., Paredes, J. C., Heim, R. R., Fye, F. K., Soto, R. A., Therrell, M. D., Cleaveland, M. K., \& Stahle, D. K. (2011). Major Mesoamerican droughts of the past millennium. Geophysical Research Letters, 38(5). https://doi.org/10.1029/2010GL046472

Stahle, D. W., Cook, E. R., Burnette, D. J., Villanueva, J., Cerano, J., Burns, J. N., Griffin, D., Cook, B. I., Acuña, R., Torbenson, M. C. A., Sjezner, P., \& Howard, I. M. (2016). The Mexican Drought Atlas: Tree-ring reconstructions of the soil moisture balance during the late pre-Hispanic, colonial, and modern eras. Quaternary Science Reviews, 149, 34-60. https://doi.org/10.1016/j.quascirev.2016.06.018

Wright, K., Johnson, K.R., Serrato Marks, G., McGee, D., Bhattacharya, T., Goldsmith, G., Tabor, C., Lacaille-Muzquiz, J.-L., Lum, G., Beramendi-Orosco, L., Precipitation in 
Mexico dominated by changes in Atlantic Meridional Overturning Circulation, in prep. for Science Advances. 